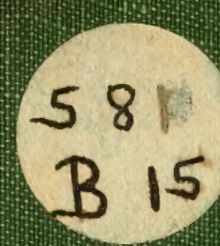

ONT ARIO

\title{
HICH SCHOOL
}

BECINNERS' BOTANY

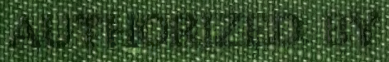

-17.7.

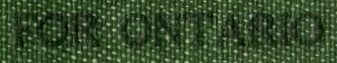

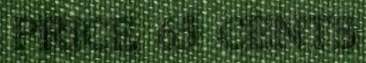

7.

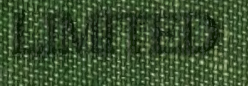




$$
581
$$


1921

B $155 B$

OTC

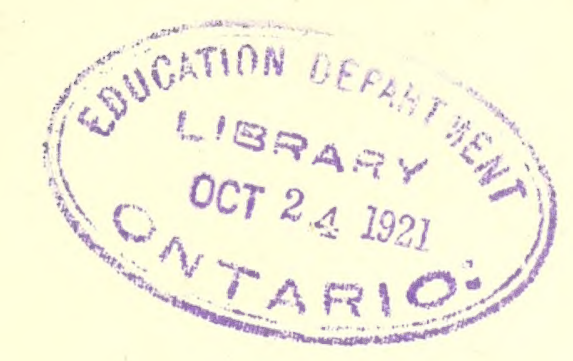


Digitized by the Internet Archive in 2008 with funding from Microsoft Corporation 


\section{BEGINNERS' BOTANY}




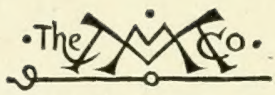

THE MACMILLAN COMPANY

NEW YORK - BOSTON - CHICAGO

SAN FRANCISCO

MACMILLAN \& CO, LiMiTED

LONDON - BOMBAY - CALCUTTA

MELBOURNE

THE MACMILLAN CO. OF CANADA, LTD. TORONTO 



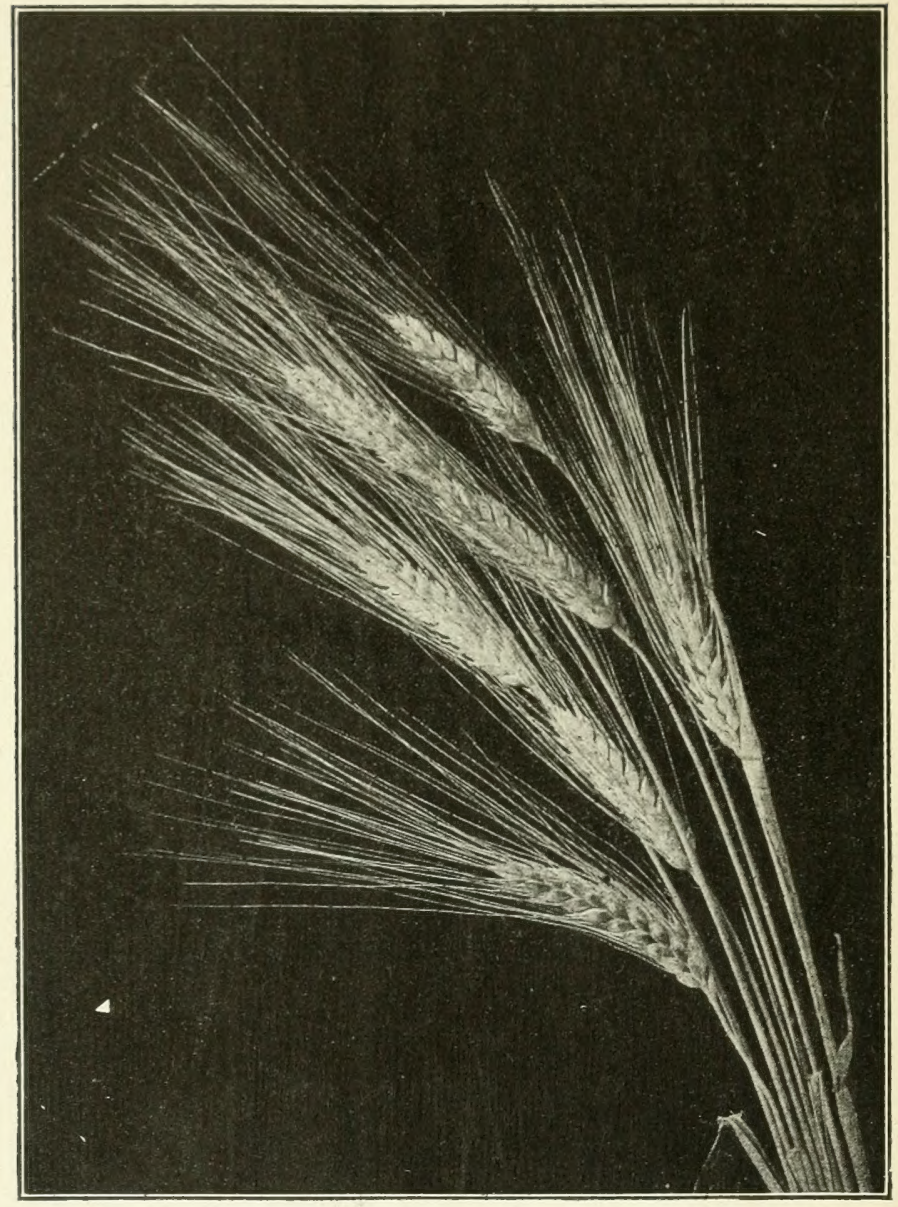

BOUQUET OF BEARDED WHEAT 


\section{BEGINNERS' BOTANY}

BY

L. H. BAILEY

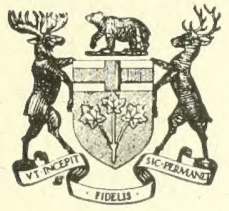

AUTHORIZED BY THE MINISTER OF EDUCATION FOR ONTARIO

TORONTO

THE MACMILLAN CO. OF CANADA, LIMITED 1921 
38515

Copyright, I92x
BY THE MACMILLAN CO. OF CANADA LTD. 


\section{PREFACE}

Is all teaching of plants and animals to begimners, the plants themselves and the animals themselves should he made the theme, rather than any amount of definitions and of mere study in hooks. l3ooks will he very useful in guiding the way, in arranging the subjects systematically, and in explaining obscure points; but if the pupil does not know the living and growing plants when he has completed his course in botany, he has not acquired very much that is worth the while.

It is well to acquaint the beginner at first with the main features of the entire plant rather than with details of its parts. He should at once form a mental picture of what the plant is, and what are some of its broader adaptations to the life that it leads. In this book, the pupil starts with the entire branch or the entire plant. It is sometimes said that the pupil cannot grasp the idea of struggle for exist. ence until he knows the names and the use's of the different parts of the plant. This is an error, although well established in present-day methods of teaching.

Another very important consideration is to adapt the statement of any fact to the understanding of a beginner. It is easy, for example, to fall into technicalities when dis. cussing osmosis; but the minute explanations would mean nothing to the beginner and their use would tend to confuse the picture which it is necessary to leave in the pupil's mind. Even the use of technical forms of expression would probably not go far enough to satisfy the trained physicist. 
It is impossible ever to state the last thing about any proposition. All knowledge is relative. What is very elementary to one mind may be very technical and adranced to another. It is neither necessary nor desirable to safeguard statements to the beginner by such qualifications as will make them satisfactory to the critical expert in science. The teacher must understand that while accuracy is always essential, the degrec of statcment is equally important when teaching beginners.

The ralue of biology study lies in the work with the actual objects. It is not possible to provide specimens for every part of the work. nor is it always desirable to do so ; for the beginning pupil may not be able to interest himself in the objects, and he may become immersed in details before he has arrived at any general vicw or reason of the subject. Great care must be exercised that the pupil is not swamped. Mere book work or memory stuffing is useless, and it may dwarf or divert the sympathies of active young minds.

The present tendency in secondary education is away from the formal technical completion of separate subjects and toward the developing of a workable training in the activities that relate the pupil to his own life. In the natural science field, the tendency is to attach less importance to hotany and zoology as such h, and to lay greater stress on the processes and adaptations of life as expressed in plants and animals. Edueation that is not applicable, that does not put the pupil into touch with the living knowledge and the affairs of his time, may be of less educative value than the learning of a trade in a shop. We are beginning to learn that the ideals and the abilities should be developed out of the commoin surroundings and affairs 
of life rather than imposed on the pupil as a matter of abstract unrelated theory.

It is much better for the beginning pupil to acquire a real conception of a few central principles and points of view respecting common forms that will enable him to tie his knowledge together and organize it and apply it, than to familiarize himself with any number of mere facts about the lower forms of life which, at the best, he can know only indirectly and remotely. If the pupil wishes to go farther in later years, he may then take up special groups and phases. 



\section{CONTENTS}

CHAPTER

I. No Two Plants or Parts are Alike • • • I

II. The Struggle to Live . . . . . . 4

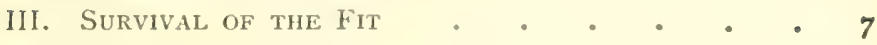

IV. Plant Societies . • • • • • . 9

V. The Plant Body . . . . . . . I5

VI. SeEds and Germination . • . • . 20

VII. ThE RoOT - The Forms of RoOTs . . . 32

VIII. The Root-Function and Structure . . $\quad 3^{8}$

IX. The Stem - Kinds ANd Forms - Pruning • • 49

X. The Stem-Its General Structure - • . 59

XI. Leaves - Form and Position . . . . . 73

XII. Leaves - Structure and ANatomy • • • 86

XIII. LEAVES - FUNCTION OR WORK . . . . . . 92

XIV. Dependent Plants . . . . . . . 106

XV. Winter and DORMant Buds • . . . . . II

XVI. BUD PROPAgation . . . . . . . 12I

XVII. How Plants Climb . . . . . . 127

XVIII. The Flower - Its Parts and Forms . . . I 33

XiX. The Flower-Fertilization and Pollination . 144

XX. Flower-Clusters . . . . . I55

XXI. FruItS . . . . . . . . . I63

XXII. Dispersal OF SEeds . . . • . . 172

XXIII. Phenogams and Cryptogams • . . . 176

XXIV. Studies IN CRyptogams ...$\quad \cdot \quad$ i 82

INDEX . . . . . . . . 205 



\title{
BEGINNERS' BOTANY
}

\author{
CHAPTER I
}

NO TWO PLANTS OR PARTS ARE ALIY̌E

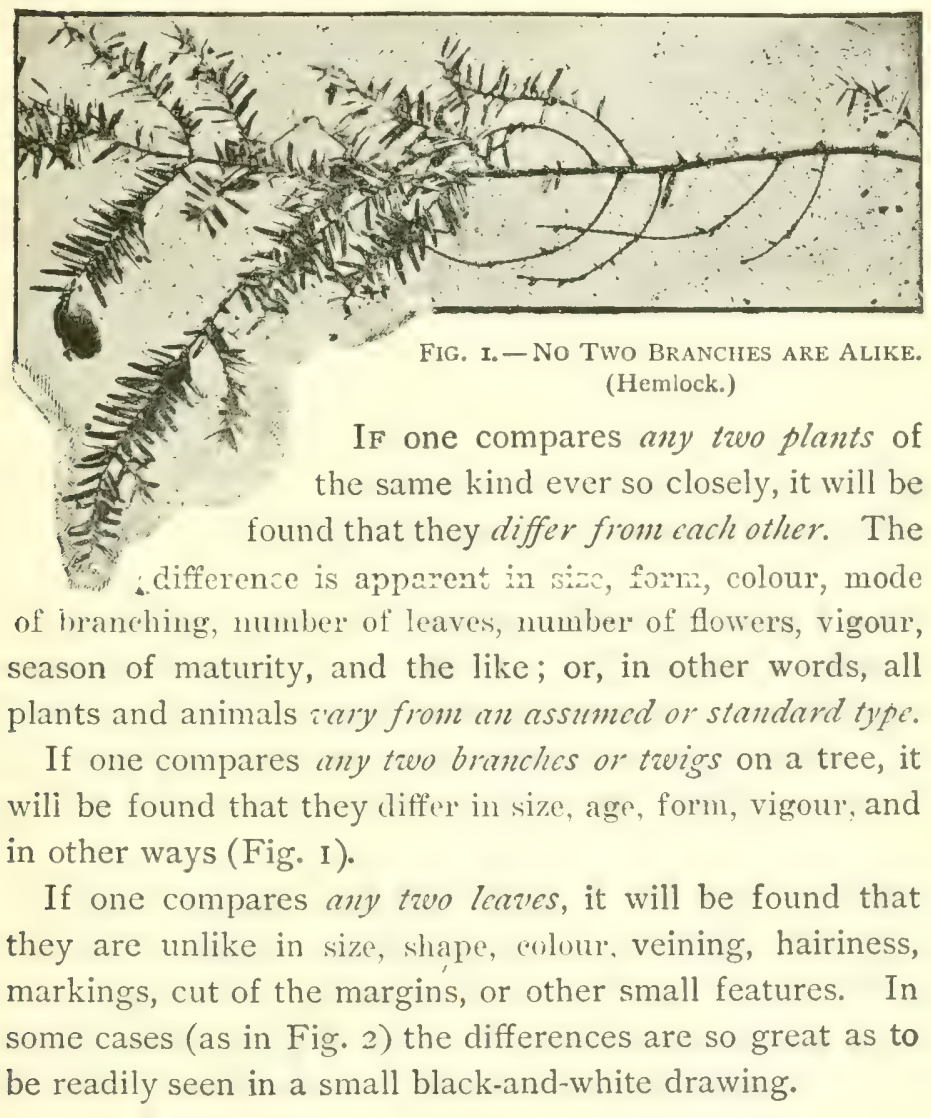


If the pupil extends his observation to animals, he will still find the same truth; for probably no two liaing objects aw cract duplicates. If any person finds two objects that he thinks to be exactly alike, let him set to work to

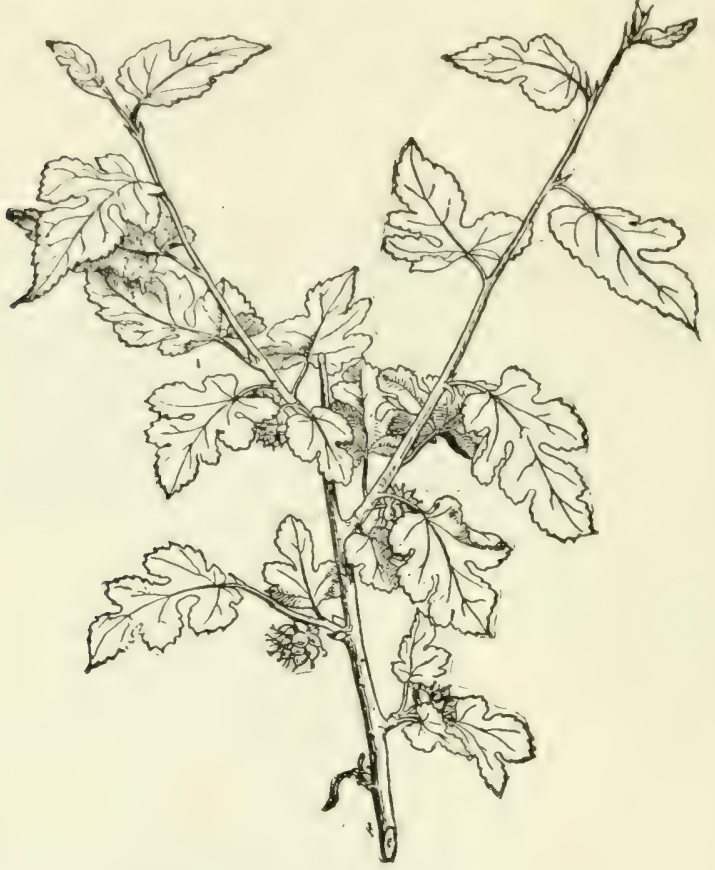

FIG. 2. - No TWo LEAVES ARE AlikE.

discover the differences, remembering that nothing in nature is so small or apparently trizial as to be overlooked.

Variation, or differences between organs and also between organisms, is one of the most significant facts in nature.

Suggestions. - The first fact that the pupil should acquire about plants is that no two are alike. The way to apprehend this great fact is to see a plant accurately and then to compare it with 
another plant of the same species or kind. In order to direct and concentrate the observation, it is well to set a certain number of attributes or marks or qualities to be looked for. 1. Suppose any two or more plants of corn are compared in the following points, the pupil endeavouring to determine whether the parts exactly agree. See that the observation is close and accurate. Allow no guesswork. Instruct the pupil to measure the parts when size is involved.

(1) Height of the plant.

(2) Does it branch? How many secondary stems or "suckers" from one root?

(3) Shade or colour.

(4) How many leaves.

(5) Arrangement of leaves on stem.

(6) Measure length and breadth of six main leaves.

(7) Number and position of ears; colour of silks.

(8) Size of tassel, and number and size of its branches.

(9) Stage of maturity or ripeness of plant.

(10) Has the plant grown symmetrically, or has it heen crowlewl by other plants or been obliged to struggle for light or room?

(11) Note all unusual or interesting marks or features.

(12) Always make note of comparative vigour of the plants.

Note to Teacher. - The teacher should always insist on personal work by the pupil. Every pupil should handle and study the object by himself. Books and pictures are merely guides and helps. So far as possible, study the plant or animal just where it growes naturally.

Notebooks. - Insist that the pupils make full notes and preserve these notes in suitable books. Note-taking is a powerful aid in organizing the mental processes, and in insuring accuracy of observation and record. The pupil should draw what he sees, even though he is not expert with the pencil. The drawing should not be made for looks, but to aid the pupil in his orderly study of the object ; it should be a means of self-expression. 


\section{CHAPTER II}

\section{THE STRUGGLE TO LIVE}

Every plant and animal is exposert to unfavourable conritions. It is obliged to eontend with these conditions in order to live.

No two plants or parts of plants are identically exposed to the conditions in which they live. The large branches

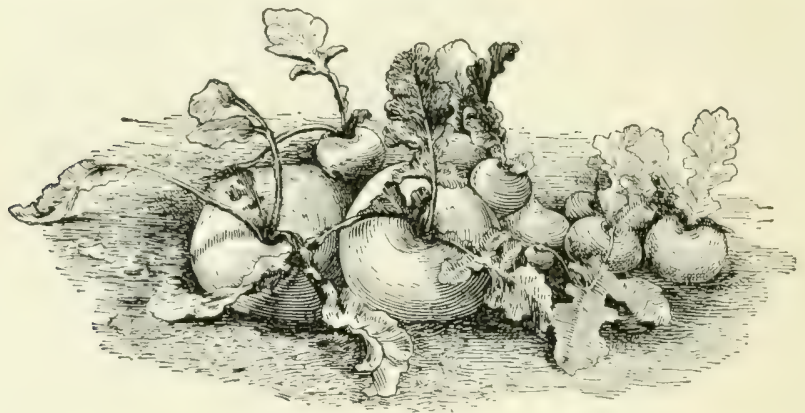

Fig. 3.-A BATTLE FOR LifE.

in Fig. I probably had more room and a better exposure to light than the smaller ones. Probably no two of the leaves in Fig. 2 are equally exposed to light, or enjoy identical advantages in relation to the food that they receive from the tree.

Examine any tree to determine under what advantages or disadvantages any of the limbs may live. Examine similarly the different plants in a garden row (Fig. 3); or the different bushes in a thicket; or the different trees in a wood. 
The plant nieets its conditions by sucumbing to them (that is, by dying), or by adupting itself to them.

The tree mects the cold by ceasing its active growth, hardening its tissues, dropping its leaves. Many herbaceous or soft-stemmed plaints meet the cold by dying to the ground and withdrawing all life into the root parts. Some plants meet the cold by dying outright and providing abundance of seeds to perpetuate the kind next season.

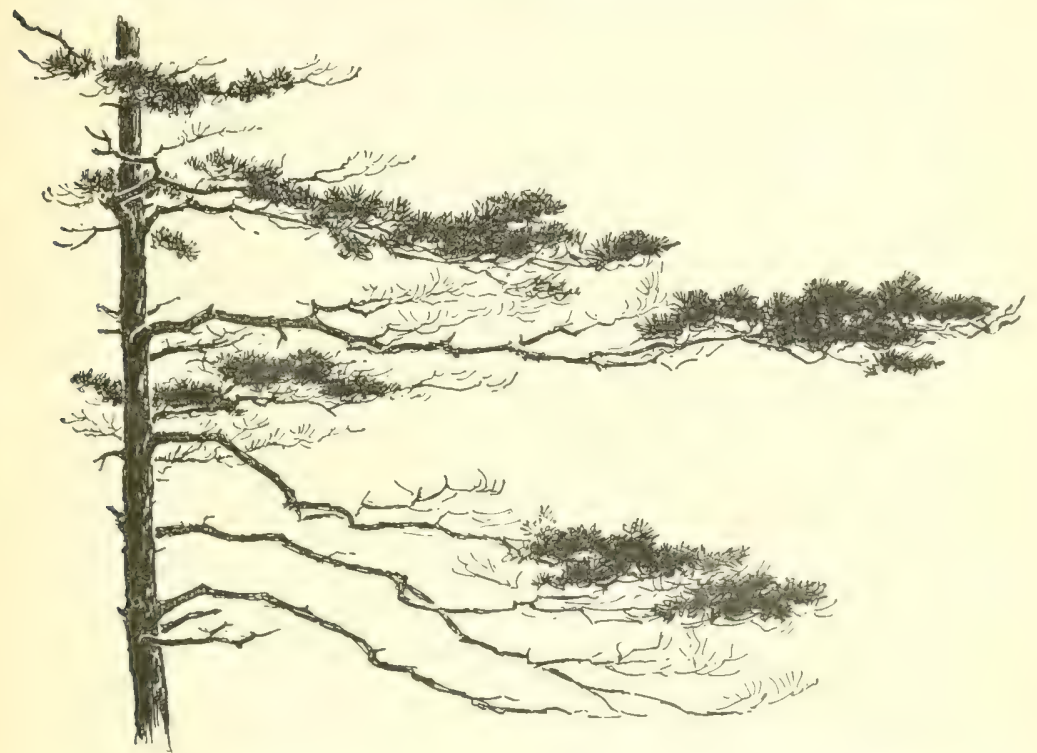

Fig. 4. - Tile Reach for Light of a Tree on tile Edie of a wood.

Plants adapt thomsclic's to light by growing toward it (Fig. 4); or by hanging their leaves in such position that they catch the light; or, in less sunny places, by expanding their leaf surface, or by greatly lengthening their stems so as to overtop their fellows, as do trees and vines.

The adaptations of plants will afford a fertile fie?d of study as we proceed. 
Struggle for existence and adaptation to conditions are among the most significant facts in nature.

The sum of all the conditions in which a plant or an animal is placed is called its environment, that is, its surroundings. The environment comprises the conditions of climate, soil, meisture, exposure to light, relation to food supply, contention with other plants or animals. The organism adupts itsilf to its cnvironment, or clse it aveakcns or dics. Every weak branch or plant has undergone some hardship that it was not wholly able to withstand.

SugGestions.-The pupil should study any plant, or branch of at plant, with reference to the position or condition under which it grows, and compare one plant or branch with another. With animals, it is common knowlerlge that every animal is alert to avoid or to escape danger, or to protect itself. 2 . It is well to begin with a branch of a tree, as in Fig. 1. Note that no two parts are alike (Chap. I). Note that some are large and strong and that these stand farthest towarl light and room. Some are very small and weak, barely able to live miler the eompetition. Some have died. The pupil can easily determine which of the dead branches perished first. He should take note of the position or place of the branch on the tree, and determine whether the greater part of the dead twigs are toward the centre of the tree top or tomard the outside of it. Determine whether accident has overtaken any of the parts. 3. Let the pupil examine the top of any thick old apple tree, to see whether there is any struggle for existence and whether any limbs have perished. 4. If the pupil has access to a forest, let him determine why there are no branches on the trunks of the old trees. Fxamine a tree of the same kind growing in an open field. 5. A row of lettuce or other plants sown thick will soon show the competition between plants. Any fence row or weedy place will also show it. Why does the farmer destroy the weeds among the corn or potatoes? How does the florist reduce compet on co 4 criest terms? what is the result? 


\section{CHAPTER III}

\section{THE SURVIVAL OF THE FIT}

THE plants that most perfectly meet their conditions are able to persist. Thiy porpetuate thomsclies. Their offspring are likely to inherit some of the attributes that enabled them successfully to meet the battle of life. The fit (those best adapted to their conditions) tend to survive.

Adaptation to conditions depends on the fact of variation; that is, if plants were perfectly rigid or invariable (all exactly alike) they could not meet new conditions. Conditions are necessarily new for every organism. It is impossible to picture a perfectly inflexible and stable succession of plants or animals.

Breeding. - Man is able to modify piants and animals. All our common domestic animals are very unlike their original ancestors. So all our common and lons-cultivated plants have varied from their ancestors. Even in some plants that have been in cultivation less than a century the change is marked: compare the common black-cap raspberry with its common wild ancestor, or the cultivated black- Fig. 5. - Desirabie and Uvdesirable: berry with the wild form.

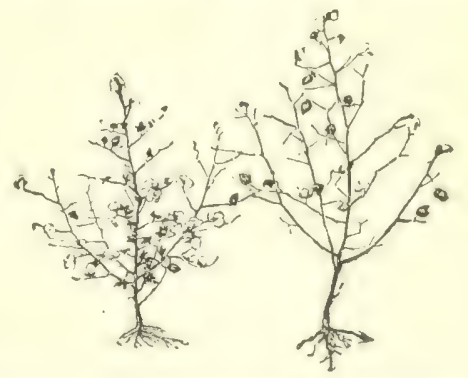

By choosing seeds from a plant that pleases him, the breeder may be able, under given conditions, to produce 


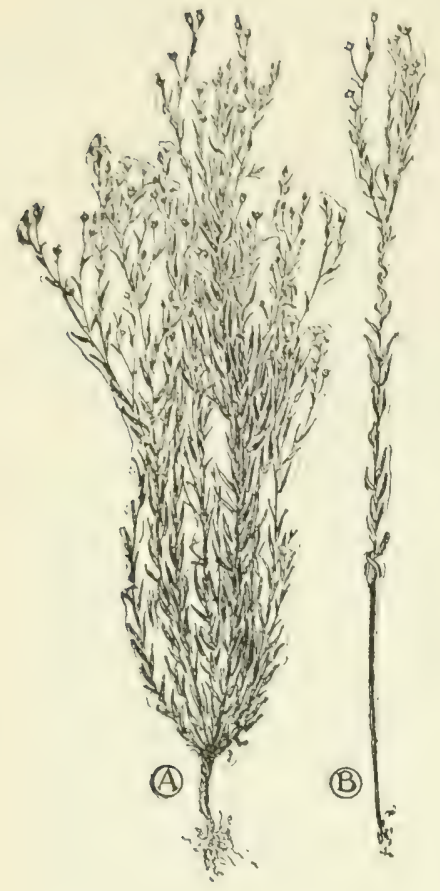

Fig. 6. - FlaX BREEDiNG.

$A$ is a plant grown for seed production: I) for tilre production. Why?

numbers of plants with more or less of the desired qualities; from the best of these, he may again choose; and so on until the race becomes greatly improved (Figs. 5, 6, 7). This process of continuously choosing the most suitable plants is known as selection. A somewhat similar process proceeds in wild nature, and it is then known as natural selection.

Suggestions. -6. Every pupil should undertake at least one simple experiment in selection of seed. $\mathrm{He}$ may select kernels from the best plant of corn in the field, and also from the poorest plant,-having reference not so much to mere incidental size and vigour of the plants that may be due to accidental conditions in the field, as to the apparently constitutional strength and size, number of ears, size of ears, perfectness of ears and kernels, habit of the plant as to suckering, and the like. The seeds may be saved and sown the next year. Every crop can no doubt be very greatly improved by a careful process of selection extending over a series of years. Crops are increased in yield or efficiency in three ways: better general care; enriching the land in which they grow; attention to breeding.

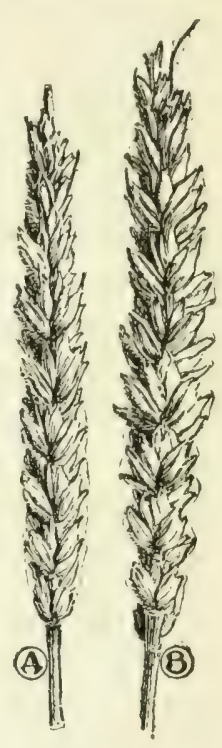

FIG. 7.-BREEDING.

$A$, effect from breed. ing from smallest grains (after four years), average head; $B$, result from breeding from the plumpest and heaviest grains (after four years), average head. 


\section{CHAPTER IV}

\section{PLANT SOCIETIES}

In the long course of time in which plants have been accommodating themselves to the varying conditions in which they are obliged to grow, they ha'te become adupted to cary different cnvironment. Certain plants, therefore, may live together or near each other, all enjoying the same general conditions and surroundings. These aggregations of plants that are adapted to similar general conditions are known as plant societies.

Moisture and temperature are the leading factors in determining plant societies. The great geographical societies or aggregations of the plant world may conveniently be associated chiefly with the moisture supply, as: wet-region socictics, comprising aquatic and bog vegetation (Fig. 8); arid-region socictics, comprising desert and most sand-region vegetation; mid-resion socictie's, comprising the mixed vegetation in intermediate regions (Fig. 9), this being the commonest type. Much of the sharacteristic scenery of any place is due to its plant societies. Arid-region plants usually have small and hard icaves, apparently preventing too rapid loss of water. Usually, also, they are characterized by stiff growth, hairy covering, spines, or a much-contracted plant-body, and often by large underground parts for the storage of water.

Plant societies may also be distinguished with reference to latitude and temperature. There are tropical socictics, temperateregion socictics, borcal or cold-region socictics. 
With reference to altitude, societies might be classified as lowiland (which are chiefly wet-region), intrmediate (chiefly mid-region), subalpine or mid-mountain (which are chiefly boreal), alfine or high-monntain.

The above classifications have reference chiefly to great geographical floras or societies. But there are socictics within socictics. There are small societies coming within the experience of every person who has ever seen plants

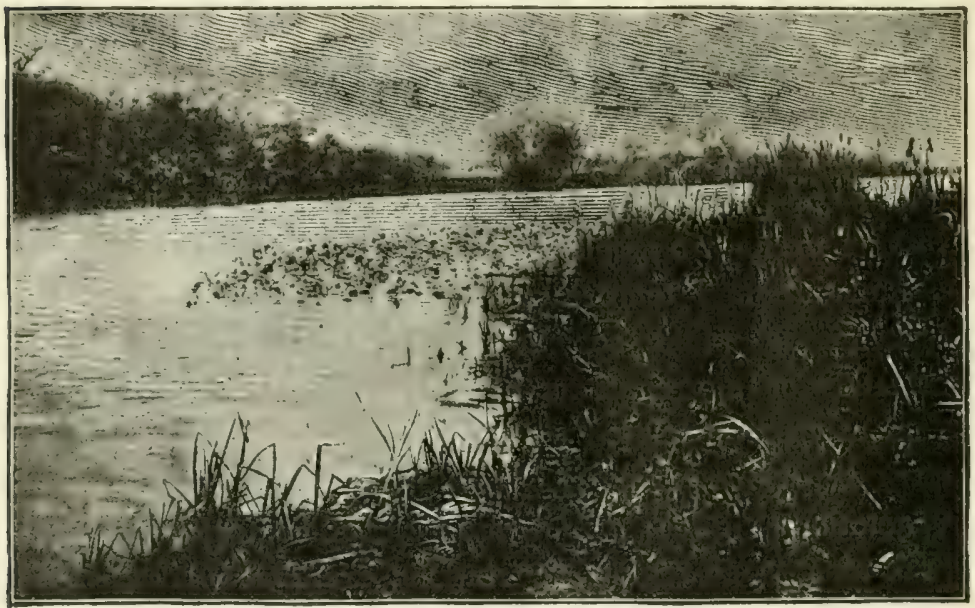

Fig. 8. - A WeT-REgION SOCIETY.

growing in natural conditions. There are roadside, fencerow, lawn, thicket, pasture, dune, woods, cliff, barn-yard societies. Every different place has its characteristic vegeta. tion. Note the smaller societies in Figs. 8 and 9. In the former is a water-lily society and a cat-tail society. In the latter there are grass and bush and woods societies.

Some Details of Plant Societies. - Societies may be composed of scattered and intermingled plants, or of dense clumps or groups of plants. Dense clumps or groups are usually made up of one kind of plant, and they are then 
called colonies. Colonies of most plants are transient: after a short time other plants gain a foothold amongst them, and an intermingled society is the outcome. Marked exceptions to this are grass colonies and forest colonies, in which one kind of plant may hold its own for years and centuries.

In a large newly cleared area, plants usually first establish themsclies in dense colonies. Note the great patches

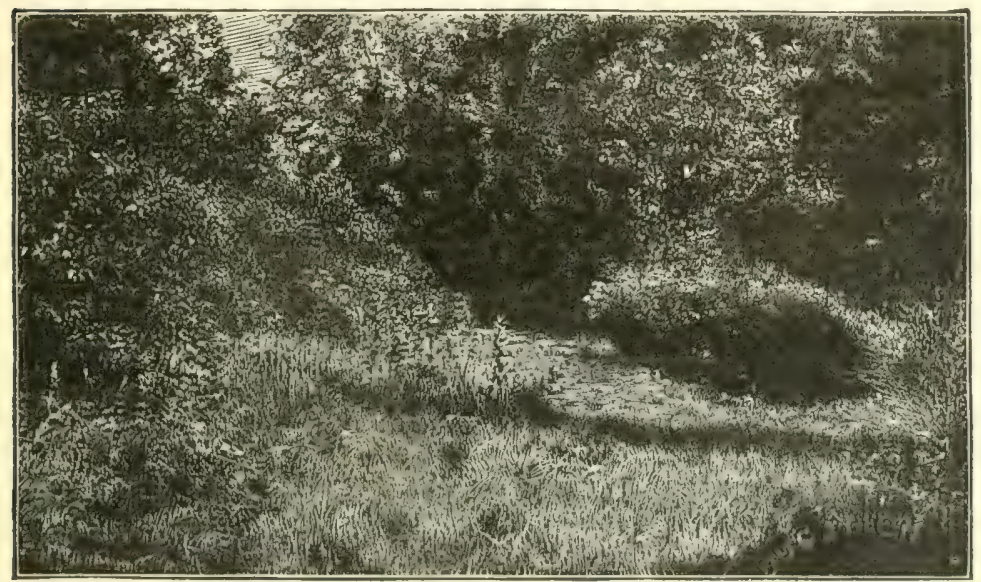

Fig. 9.-A Mid-REgION SOCIETY.

of nettles, jewel-weeds, smart-weeds, clot-burs, fire-weeds in recently cleared but neglected swales, also the fire-weeds in recently burned areas, the rank weeds in the neglected garden, and the ragweeds and May-weeds along the recently worked highway. The competition amongst themselves and with their neighbours finally breaks up the colonies, and a mixed and intermingled flora is senerally the result.

In many parts of the world the general tcnutucy of nicglected areas is to mu into forcst. All plants rush for the 
cleared area. Herc and there bushes gain a fonthold. Young trees come up ; in time these shade the bushes and gain the mastery. Sometimes the area grows to poplars or birches, and people wonder why the original forest trees do not return; but these forest trees may be growing unobserved here and there in the tangle, and in the slow processes of time the poplars perish - for they are short-lived - and the original forest may be replaced. Whether one kind of forest or another returns will depend partly on the kinds that are most seedful in that vicinity and which, therefore, have sown themselves most profusely. Much depends, also, on the kind of undergrowth that first springs up, for some young trees can endure more or less shade than others.

Some plants associatc. They grow together. This is possible largely because they diverge or differ in charac-

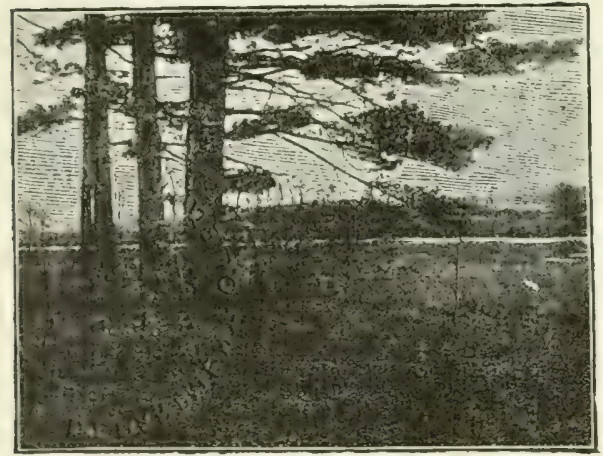

FIG. IO. - OVERGROWTH AND UNDERGROWTH IN THREE SERIES, - trees, bushes, grass. ter. Plants associate in two ways: by growing side by side; by growing above or beneatl. In sparsely populated societies, plants may grow alongside each other. In most cases, however, there is oa'crgrowth and undergrowth: one kind grows beneath another. Plants that have become adapted to shade are usually undergrowths. In a cattail swamp, grasses and other narrow-leaved plants grow in the bottom, but they are usually unseen by the casual 
observer. Note the undergrowth in woods or under trees (Fig. IO). Observe that in pine and spruce forests there is almost no undergrowth, partly because there is very little light.

On the same area the societies may differ at different times of the year. There are spring, summer, and fall societies. The knoll which is cool with grass and strawberries in June may be aglow with goldenrod in September. If the bank is examined in May, look for the young plants that are to cover it in July and October; if in September, find the dead stalks of the flora of May. What succeeds the skunk cabbage, hepaticas, trilliums, phlox, violets, buttercups of spring? What precedes the wild sunflowers, ragweed, asters, and goldenrod of fall?

The Landscape.- To a large extent the colour of the landscape is determined by the character of the plant societies. Evergreen societies remain green, but the shade of green varies from season to season; it is bright and soft in spring, becomes dull in midsummer and fall, and assumes a dull yellow-green or a black-green in winter. Deciduous societies vary remarkably in colour-from the dull browns and grays of winter to the hrown greens and olive-greens of spring, the staid greens of summer, and the brilliant colours of autumn.

The autumn colours are due to intermingled shades of green, yellow and red. The coloration varies with the kind of plant, the special location, and the season. Even in the same species or kind, individual plants differ in colour; and this individuality usually dstinguishes the plant year by year. That is, an oak which is maroon red this autumn is likely to exhihit that range of colour every year. The autumn colour is associated with the natural maturity and death of the leaf', but it is most brilliant in long and open 
falls - largely because the foliage ripens more gradually and persists longer in such seasons. It is probable that the autumn tints are of no utility to the plant. Autumn cotours are mot cunsed by frost. Berause of the long, dry falls and the great variety of plants, the autumnal colour of the American landscape is phenomenal.

Ecology. - The study of the relationships of plants and animals to each other and to seasons and environments is known as ecology (still written ecology in the dictionaries). It considers the habits, habitats, and modes of life of living things - the places in which they grow, how they migrate or are disseminated, means of collecting food, their times and seasons of flowering, producing young, and the like.

Suggestions. - One of the best of all subjects for school instruction in botany is the study of plant societies. It adds definiteness and zest to excursions. 7. Let each excursion be confined to one or two societies. Visit one day a swamp, another day a forest, another a pasture or meadow, another a roadside, another a weedy field, another a cliff or ravine. Visit shores whenever possible. Each pupil should be assigned a bit of ground - say to or $20 \mathrm{ft}$. square - for special study. He should make a list showing (I) how many kinds of plants it contains, ( 2 ) the relative abundance of each. The lists secured in different regions should be compared. It does not matter greatly if the pupil does not know all the plants. He may count the kinds without knowing the names. It is a good plan for the pupil to make a dried specimen of each kind for reference. The to discover why the plants grow as they do. Note what kinds of plants grow next each other; and which are undergrowth and which overgrowth; and which are erect and which wide-spreading. Challenge every plant society. 


\section{CHAPTER V}

\section{THE PLANT BODY}

The Parts of a Plant. - Our familiar plants are made up cf several distinct parts. The most prominent of these parts are root, stcm, leaf, flower, fruit, and sced. Familiar plants differ wonderfully in size and shape, - from fragile mushrooms, delicate waterweeds and pond-scums, to floating leaves, soft grasses, coarse weeds, tall bushes, slender climbers, gigantic trees, and hanging moss.

The Stem Part. - In most plants there is a main contral part or sluaft on which the other or sccondary parts are borne. This main part is the plant axis. Above ground, in most plants, the main plant axis bears the branches, leaves, and flowers; below ground, it bears the roots.

The rigid part of the plant, which persists over winter and which is left after leaves and flowers are fallen, is the framework of the plant. The framework is composed of both root and stem. When the plant is dead, the framework remains for a time, but it slowly decays. The dry winter stems of weeds are the framework, or skeleton of the plant (Figs. I I and I2). The framework of trees is the most conspicuous part of the plant.

The Root Part. - The root bears the stem at its apex, but otherwise it normally bears only root-branches. The stem, however, bears liaves, flowers, and fruits. Those living surfaces of the plant which are most exposed to light are grech or highly coloured. The root tends to grow downward, but the stem tends to grow upward toward light 
and air. The plant is anchored or fixed in the soil by the roots. Plants have been called "earth parasites."

The Foliage Part. - The lear's procede the flowers in point of time or life of the plant. The flowers alivays pricude the fruits and sicds. Many plants die when the seeds have matured. The whole mass of leaves of any

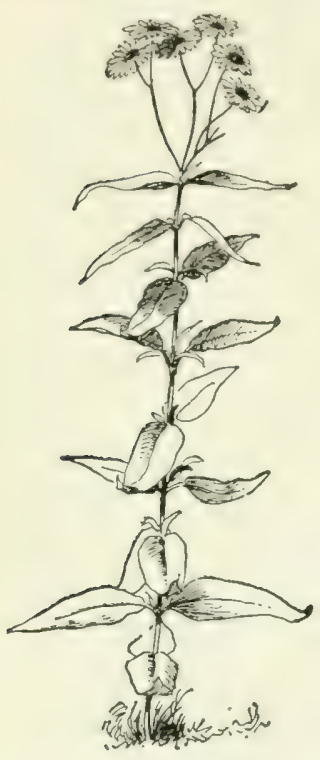

Fig. it. - Plant of a

WILD SUNFLOWER.

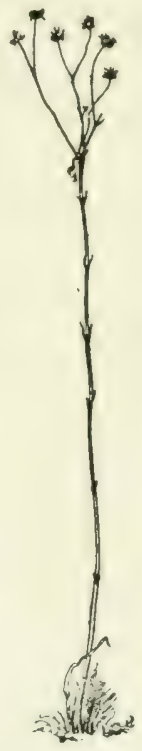

FIG. I2. - FRAMEWORK OF FIG. II. plant or any branch is known as its foliage. In some cases, as in crocuses, the flowers seem to precede the leaves; but the leaves that made the food for these flowers grew the preceding year.

The Plant Generation.

- The course of a plant's life, with all the events through which the plant naturally passes, is known as the plant's life-history. The life-history embraces various stages, or epochs, as domant sced, gemination, growth, flowering, fruting. Some plants run their course in a few weeks or months, and some live for centuries.

The entire life-period of a plant is called a generation. It is the whole period from birth to normal death, without reference to the various stages or events through which it passes.

A generation begins with the young seed, not with germi- 
nation. It cnds with death - that is, when no life is left in any part of the plant, and only the seed or spore remains to perpetuate the kind. In a bulbous plant, as a lily or an onion, the generation does not end until the bulb dies, even though the top is dead.

When the generation is of only one season's duration, the plant is said to be annual. When it is of two seasons, it is biennial. Biennials usually bloom the second year. When of three or more seasons, the plant is perennial. Examples of annuals are pigweed, bean, pea, garden sunflower; of biennials, evening primrose, mullein, teasel; of perennials, dock, most meadow grasses, cat-tail, and all shrubs and trees.

Duration of the Plant Body. - Plant structures which are more or less soft and which die at the close of the season are said to be herbaceous, in contradistinction to being ligneous or woody. A plant which is herbaceous to the ground is called an herb; but an herb may have a woody or perennial root, in which case it is called an herbaceous perennial. Annual plants are classed as herbs. Examples of herbaceous perennials are buttercups, bleeding heart, violet, waterlily, Bermuda grass, horse-radish, dock, dandelion, goldenrod, asparagus, rhubarl, many wild sunflowers (Figs. 11, 12).

Many herbaceous perennials have short gencrations. They become weak with one or two seasons of flowering and gradually die out. Thus, red clover usually begins to fail after the second year. Gardeners know that the best bloom of hollyhock, larkspur, pink, and many other plants, is secured when the plants are only two or three years old.

Herbaceous perennials which die away each season to bulbs or tubers, are sometimes called pseud-annuals (that 
is, fulse anmulst. ()f such atre lily, rocus, onion, potato, and bull nettle.

True annuals reach old age the first year. Plants which are normally peremnial may' bicome anmal in a shorter. siason climate by bing lillid by frost, rather than by dying naturally at the end of a season of growth. They are climatic anmuals. Such plants are called plur-annuals in the short-season region. Many tropical perennials are plur-

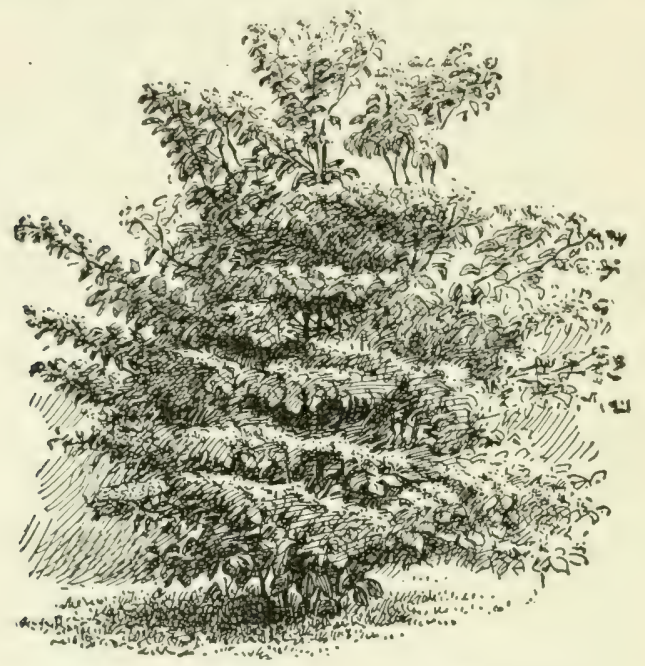

Fig. 13.-A SHRUB OR BUSH. Dogwood osier.

annuals when grown in the north, but they are treated as true annuals because they ripen sufficient of their crop the same season in which the seeds are sown to make them worth cultivating, as tomato, red pepper, castor bean, cotton. Name several vegetables that are planted in gardens with the expectation that they will bear till frost comes.

Woody or ligneous plants usually live longer than herbs. Those that remain low and produce several or 
many similar shoots from the base are called shrubs, as lilac, rose, elder, osier(Fig. I3). Low and thick shrubs are bushes. Plants that produce one main trunk and a more or less elevated head are trees (Fig. I4). All shrubs and trees are perennial.

Every plant makes an effort to propagate, or to perpetuate its kind; and, as far as we can see, this is the end for which the plant itself lives. The seed or spore is the final product of the plant.

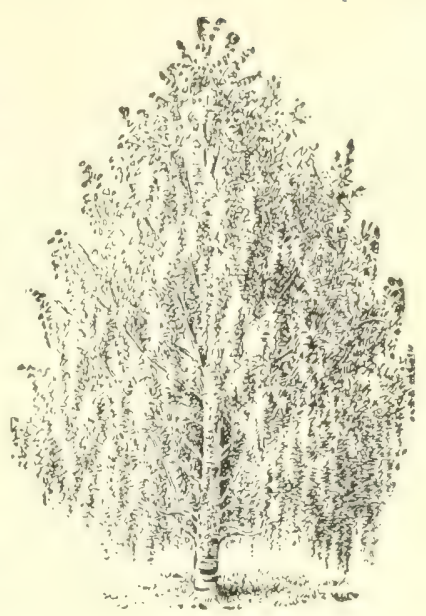

FIG. I4. - A TRLE. The weeping birch.

Suggestions. - 8. The teacher may assign each pupil to one plant in the school yard, or field, or in a pot, and ask him to bring out the points in the lesson. 9. The teacher may put on the board the names of many common plants anc ask the pupils to classify into annuals, pseud-annuals, plur-annuals (or climatic annuals), biennials, perennials, herbaceous perennials, ligneous perennials, herbs, bushes, trees. Every plant grown on the farm should be so classified: wheat, oats, corn, buckwheat, timothy, strawberry, raspberry, currant, tobacco, alfalfa, flax, crimson clover, hops, cowpea, field bean, sweet potato, peanut, radish, sugar-cane, barley, cabbage, and others, Name all the kinds of trees you know. 


\section{CHAPTER VI}

\section{SEEDS AND GERMINATION}

THE seed contains a miniature plant, or embryo. The embryo usually has three parts that have received names: the stemlet, or caulicle; the seed-leaf, or cotyledon (usually I or 2); the bud, or plumule, lying between or

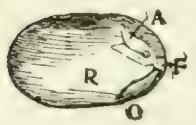

FIG, I5. - PAR'TS OF THE BEAN.

$R$, cotyledon; $O$, caulicle; $A$, plumule; $F$, first node. above the cotyledons. These parts are well seen in the common bean (Fig. I5), particularly when the seed has been soaked for a few hours. One of the large cotyledons comprising half of the bean - is shown at $R$. The caulicle is at $O$. The plumule is shown at $A$. The cotyledons are attached to the caulicle at $F$ : this point may be takcn as the first node or joint.

The Number of Seed-leaves. - All plants having two seed-leaves belong to the group called dicotyledons. Such seeds in many cases split readily in halves, $\operatorname{cog}$. a bean. Some plants have only one seed-leaf in a seed. They form a group of plants called monocotyledons. Indian corn is an example of a plant with only one seed-leaf : a grain of corn does not split into ha!ves as a bean does. Seeds of the pine family contain more than two cotyledons, but for our purposes they may be associated with the dicoty. ledons, although really forming a different group.

These two groups - the dicotyledons and the monocotyledons - represent two great natural divisions of the vegetable kingdom. The dicotyledons contain the woody 
bark-bearing trees and bushes (except conifers), and most of the herbs of temperate climates except the grasses, sedges, rushes, lily tribes, and orchids. The flower-parts are usually in fives or multiples of five, the leaves mostly netted-veined, the bark or rind distinct, and the stem often bearing a pith at the centre. The monocotyledons usually have the flower-parts in threes or multiples of three, the leaves long and parallel-veined, the bark not separable, and the stem without a central pith.

Every seed is provided with food to support the germinating plart. Commonly this food is starch. The food may be stored in the cotyledons, as in bean, pea, squash ; or outside the cotylidons, as in castor bean, pine, Indian corn. When the food is outside or around the embryo, it is usually called endosperm.

Seed-coats; Markings on Seed. - The embryo and endosperm are inclosed within a covering made of two or more layers and known as the seed-coats. Over the point of the caulicle is a minute hole or a thin place in the coats known as the micropyle. This is the point at which the pollen-tube entered the forming ovule and through which the caulicle breaks in

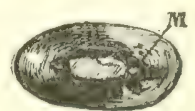

FIG. I0. - EXTTERNAI, PARIS OF BEAN. germination. The micropyle is shown at $M T$ in Fig. 16. The scar where the seed broke from its funiculus (or stalk that attached it to its pod) is named the hilum. It occupies a third of the length of the bean in Fig. I6. The hilum and micropyle are always present in seeds, but they are not always close together. In many cases it is difficult to identify the micropyle in the dormant seed, but its location is at once shown by the protruding caulicle as germination begins. Opposite the micropyle in the bean (at the other end of the hilum) is an elevation known as the raphe. 
This is formed by a union of the funiculus, or seed-stalk, with the seed.coats, and through it food was transferred for the development of the seed, but it is now functionless.

Seeds differ wonderfully in size, shape, "olour, and other characteristics. They also vary in longevity. These characteristics are piculiar to the specics or find. Some seeds maintain life only a few weeks or even days, whereas others will "keep" for ten or twenty years. In special cases, seeds have retained vitality longer than this limit, but the stories that live seeds, several thousand years old, have been taken from the wrappings of mummies are unfounded.

Germination. - The embryo is not dead ; it is only dor. mant. WVhen supplicd with moisture, wamth, and oxygen (air), it awalies and growes: this growuth is germination. The embryo lives for a time on the stored food, but gradually the plantlet secures a foothold in the soil and gathers food for itself. When the plantlet is finally able to sluift for itself, germination is complete.

Early Stages of Seedling. - The germinating seed first absorbs water, and suclls. The starchy matters gradually become soluble. The seed-coats are ruptured, the caulicle and plumule emerge. During this process the seed respires frecly, throwing off carbon dioxide ( $\mathrm{CO}$.).

The caulicle usually elongates, and from its lower end roots are enitted. The elongating caulicle is known as the hypocotyl ("below the catyledons"). That is, the hypocotyl is that part of the stem of the plantlet lying' between the roots and the cotyledon. The gencral direction of the young hypocotyl, or cmerging caulicle, is downwards. As soon as roots form, it becomes fixed and its subsequent growth tends to raise the cotyledons above the ground, as in the bean. When cotyledons rise into the 
air, germination is said to be epigeal ("above the earth"). Bean and pumpkin are examples. When the hypocotyl does not elongate greatly and the cotyledons remain under ground, the germination is hypogeal ("beneath the earth"). Pea and scarlet runner bean are examples (Fig. 48). When the germinating seed lies on a hard surface, as on closely compacted soil, the hypocotyl

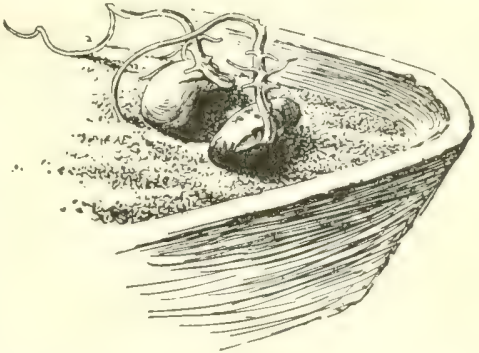

FIG. I7. - PEA. Grotesque forms assumed when the routs cannot gain entrance to the soil.

and rootlets may not be able to secure a foothold and they assume grotesque forms (Fig. 17). Try this with peas and beans.

The first internode ("between nodes") above the cotyledons is the epicotyl. It elevates the plumule into the air, and the plumule-leares expand into the first thuc liares of the plant. These first true leaves, however, may be very unlike the later leaves in shape.

Germination of Bean. - The common bean, as we have seen (Fig. I5), has cotyledons that occupy all the space

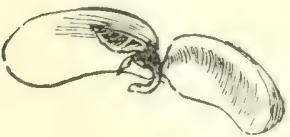

Fig. I8.-Cotritenons OF GERMINATING BE.AN SPRE.II APART To SHoIV EIONi.1TING CAULICLE AND PluMule. inside the seed-coats. When the hy. pocotyl, or elongated caulicle, emerges, the plumule-leaves have begun to enlarge, and to unfold (Fig. IS). The hypocutyl elongates rapidly. One end of it is held by the roots. The other is held by the seed-coats in the soil. It therefore takes the form of a loop, and the central part of the loop "comes up" first ( $a$, Fig. I9). Presently the cotyledons come out of the seed-coats, 


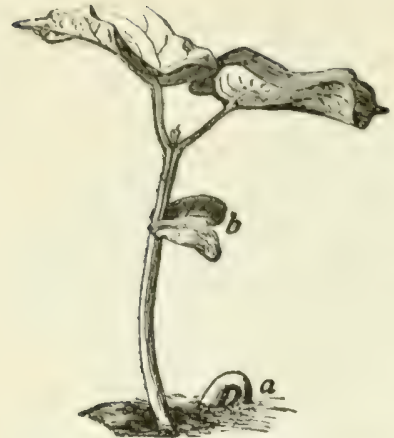

FIG. 19. - GERMINATION OF BEAN. and the plant straightens and the cotyledons expand. These cotyledons, or "halves of the bean," persist for some time (b, Fig. 19). They often become green and probably perform some function of foliage. Because of its large size, the Lima bean shows all these parts well.

Germination of Castor Bean. In the castor bean the hilum and micropyle are at the smaller end (Fig. 20). The bean "comes up" with a loop, which indicates that the hypocotyl greatly elongates. On examining germinating seed, however, it will be found

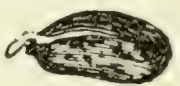

Fig. 20. - SPROUT、 ING OF CASTOR BEAN. that the cotyledons are contained inside a fleshy body, or $\operatorname{sac}(a$, Fig. 2I). This sac is the endosperm. Against its inner surface the thin, veiny cotyledons are very closely pressed, ab-

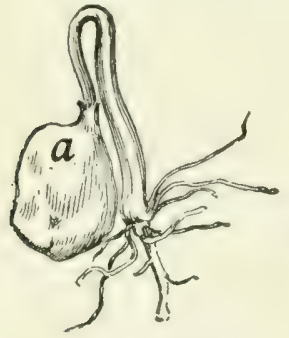

Fig. 2I. - GerminaTION OF CASTOR BEAN.

Endosperm at $a$.

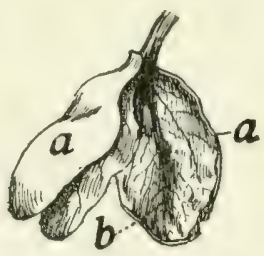

FIG. 22.-CASTOR

BEAN。

Endosperm at $a, a$; cotyledons at $b$.

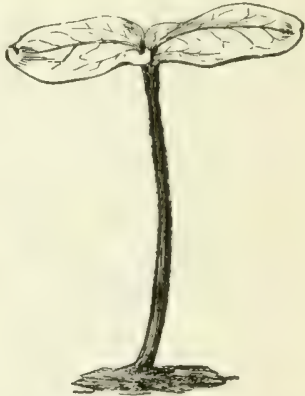

Fig. 23. - Germination Complete in CASTOR BEAN.

sorbing its substance (Fig. 22). The cotyledons increase in size as they reach the air (Fig. 23), and become functional leaves. 
Germination of Monocotyledons. - Thus far we have stud. ied dicotyledonous seeds; we may now consider the monocotyledonous group. Soak kernels of corn. Note that the micropyle and hilum are at the smaller end (Fig. 24).

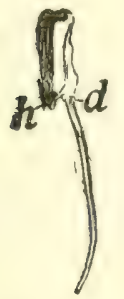

FIG. 24.-SPROUT. ING INDIAN CORN.

Hilum at $h$; micro. pyle at $d$.

Make a longitudinal section through the narrow diameter; Fig. 25 shows it. The

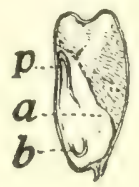

FIG. 25.-KF.RNEL OF INDIAN CORN.

Caulicle at $b$; cotyledon at $a ;$ plumule at $p$.

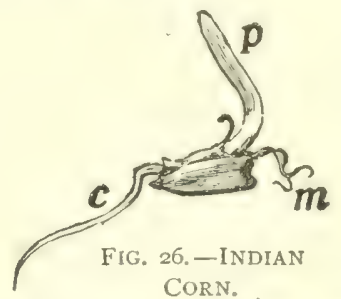

Caulicle at $c$; roots emerging at $m$; plumule at $p$.

single cotyledon is at $a$, the caulicle at $b$, the plumule at $p$. The cotyledon remains in the seed. The food is stored both in the cotyledon and as endosperm, chiefly the latter. The cmerging shoot is the plumule, with a sheathing leaf ( $p$, Fig. 26). The root is emitted from the tip of

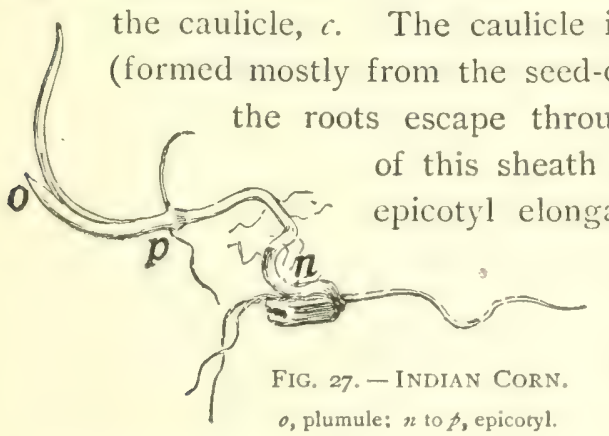

a sheath (formed mostly from the seed-coats), and some of the roots escape through the upper end of this sheath ( $m$, Fig. 26). The epicotyl elongates, particularly if the seed is planted deep or if it is kept for a time confined. In Fig.

27 the epicotyl has elongated from $n$ to $p$. The true plumule-leaf is at $o$, but other leaves grow from its sheath. In Fig. 28 the roots are seen emerging from the two ends of the caulicle. 
sheath, c. $m$; the epicotyl has grown to $p$; the first plumule-leaf is at $o$.

In studying corn or other fruits or seeds, the pupil should note how the seeds are arranged, as on the cob. Count the

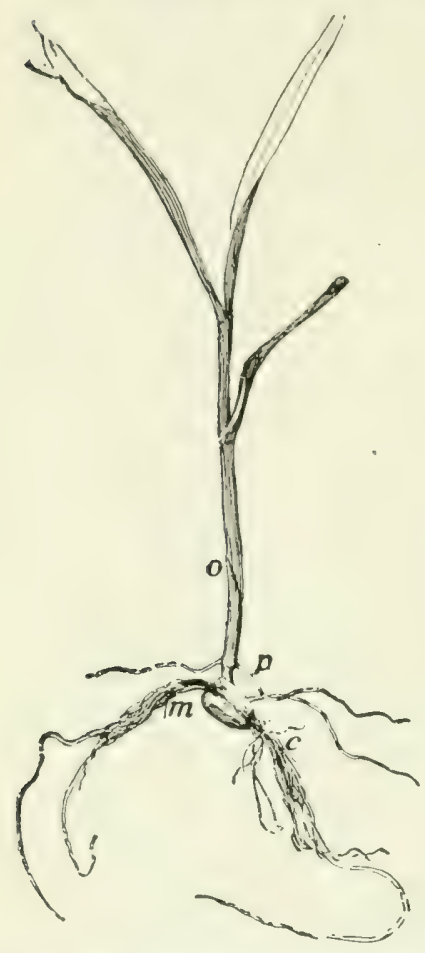

Fig. 28. - Germination is ComPLETE.

$\not$, top of epicotyl; 0 , plumule-leaf: $m$, roots; $c$, lower roots. rows on a corn cob. Odd or even in number? Always the same number? The silk is the style: find where it was attached to the kernel. Did the ear have any coverings ? Explain. Deseribe colours and markings of kernels of corn ; and of peas, beans, castor bean.

Gymnosperms. - The seeds in the pine cone, not being inclosed in a seed-vessel, readily fall out when the cone dries and the scales separate. Hence it is difficult to find cones with seeds in them after autumn has passed (Fig. 29). The cedar is also a gymno. sperm.

Remove a scale from a pine cone and draw it and the seeds as they lie in place on the upper side of the scale.

Examine the seed, preferably with a magnifying glass. Is there a hilum? The micropyle is at the bottom or little end of the seed. Toss a seed upward into the air. Why does it fall so slowly? Can you explain the peculiar whirling motion by the shape of the wing? Repeat the ex- 
periment in the wind. Remove the wing from a seed and toss it and an uninjured seed into the air together. What do you infer from these experiments?

SugGéstions. - Few subjects connected with the study of plant-life are so useful in schoolroom demonstrations as germination. The pupil should prepare the soil, plant the seeds, water them, and care for the plants. 10. Plant seeds in pots or shallow boxes. The box should not be very wide or long, and not over four inches deep. Holes may be bored in the bottom so it will not hold water. Plant a number of squash, bean, corn, pine, or other seeds about an inch deep in damp sand or pine sawdust in this box. The depth of planting should be two to four times the diameter of the seeds. Keep the sand or sawdust moist but not wet. If the class is large, use several boxes, that the supply of specimens may be ample. Cigar boxes and chalk boxes are excellent for individual pupils. It is well to begin the planting of seeds at least ten days in advance of the lesson, and to make four or five different plantings at intervals. A day or two before the study is taken up, put seeds to soak in moss or cloth. The pupil then has a series from swollen seeds to
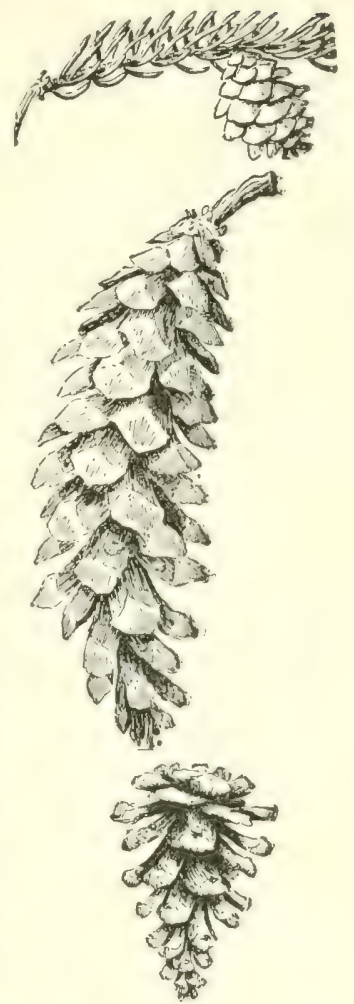

FIC. 29. - CONES OF HEMLOCK (ABOVE), White Pine, Pitch Pine. complete germination, and all the steps can be made out. Dry seeds should be had for comparison. If there is no special room for laboratory, nor duplicate apparatus for every pupil, each experiment may be assigned to a committee of two pupils to watch in the schoolroom. 11. Good seeds for study are those detailed in the lesson, and buckwheat, pumpkin, cotton, morning glory, radish, four o'clock, oats, wheat. It is best to use familiar seeds of farm and garden. Make drawings and notes of all the events in the germination. Note the effects of unusual conditions, as planting too deep and too shallow and different sides up. For hypogeal germination, use the garden pea, swirlet-rumer. or Dutch 
ease-knife hean, aenrn, horse-hestnut. Squash sonds are excelkent. for germination stmdies, beranse the entyledons berome soren and leaty and germination is rapid. Onion is execllent, exeept that it germinates too slowly. In order to study the root deselopment of germinating flantlets, it is well to provide a deceper hox with a grlase side against which the seeds are planted. 12. Observe the germinat tion of any rommon seed ahout the house premis:e: When elms, oaks, pines, or maples are alumdant, the germination of their soeds may he studied in lawns and along fenees. 13. When studying germination the pupil should note the differenees in shape and size betwerk eotyledons and plumule leaves, and between plumule leaves and the normal leaves (Fig. 30). Make drawings. 14. Make the tests deseribed in the introductory experiments with hean, eorn, the eastor bean, and other seed for starch and protrids. Test flour, oatmeal,

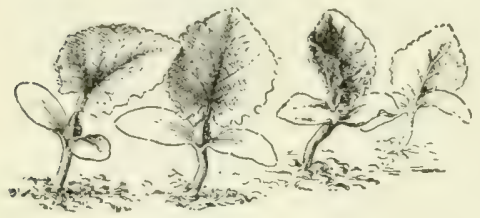

Fig. 30. - MUSKMELON SEEDLings, with the unlike seed-leaves and true leaves. rice, sunflower, four o'clock, various nuts, and any other seeds obtainable. Record your results by arranging the seeds in three classes, 1 . Nuch starch (colour blackish or purple). 2. Little starch. (pale blue or greenish), 3. No starch (brown or yellow). 15. Rate of growth of seedlings as affected by differences in tempera-

ture. Pack soft wet paper to the depth of an inch in the bottom of four glass bottles or tumblers. Put ten soaked peas or beans into each. Cover each securely and set them in places having different temperatures that vary little. (A furnace room, a room with a stove, a room without store but reached hr sunshine, an unheated room not reached by the sun). Take the temperatures occasionally with the thermometer to find difference in temperature. The tumblers in trarm places should be covered very tightly to prevent the germination from being retarded by drying ont. Record the number of seeds which sprout in each tumbler within 1 day, 2 days, 3 days, 4 days, ete. 16. Is air neessary for the germination and grouth of seertlings? Place damp blotting paper in the bottom of a hottle aud fill it three-fourths full of soaked seeds, and close it tightly with a rubber stopper or oiled cork. Prepare a "check experiment" by having another bottle mith all conditions the same exeept that it is rovered loosely that air may have access to it, and set the bottles side by side (why keen the bottles together?). Record results as in the 
preceding experiment.

17. That is the nature of the gas given off by acrminating secds? Fill a tin box or largenerked bottle with Iry beaus or peas, then add water; note how mueh they swell. Secure two fruit jars. Fill one of thein a third full of beass aud keep them moist. Allow the other to remain empty. In a day or two insert a lighted splinter er taper into each. In the empty jar the taper hurns: it contains oxygen. In the seed jar the taper goes out: the air has been replater by carbon diosile. The air in the bottle may he tested for carhon dioxile by removing some of it with a rubber lulb aztached to a glass tube (or a fountain-pen filler) and bubbling it through lime water. 18. Temprature. Usually there is a pereeptible rise in temperature in a mass of germinating seeds. This rise may be, tested with a thermometer. 19. Interior of seeds. Soak sieds for twenty-four hours and remove the coat. Distinguish the ambryo from the endosperm. Test with iodine. 20. Of what utility is the food in seeds? Soak some grains of corn overnight and remove the endosperm, being careful not to injure the fleshy cotyledon. I'lant the incomplete and also some complete grains in moist sawlust and measure their growth at intervals. (Boiling the sawdust will lestroy moulds and bacteria which might interfere with experiment.) Peas or beans may be sprouted on damp blotting paper; the cotyledons of one may be removed, and this with a normal seed equally advanced in germination may be placerl on a perforated cork floating in water in a jar so that the roots extend into the water. Their srowth may he ohserved for several weeks. 21. Effect of durliness on seeds and seedlings. A box may be placed mouth downward over a smaller box in which secdlings are groming. The empty box should rest on half-inch blocks to allow air to reach the seedlings. Note any effects on the seedlings of this watting off of the light. Another box of seedlings not so covered may be used as a theck. Lay a plank on green grass and after a reek note the change that takes place beneath it. 22. Sccdling of pinc. Plant pine seeds. Notice low they emerge. Do the cotyledons stay in the grounit? Mn many cotylerlons have they? When do the cotyledons get free from the scerl-eat? What is the last part of the eotylevion to besome free? Where is the growing point or plumule? IIow many leaves appear at onee? Does the new pine eone grow on old wood or on wool formed the same spring with the cone? Can you always funl partly grown rones on pine trees in winter? Are pine rones when mature on twoyear-old wood? How long do cones stay on a tree after the seeds have fallen out? What is the advantage of the seeds falling before the cones? 23. Home experiments. If desired, nearly all of the fore- 
going cxperiments may he tried at home. The pupil ean thus make the drawings for the notetook at home. A daily record of measurements of the change in size of the varions parts of the seedling

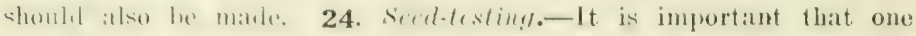

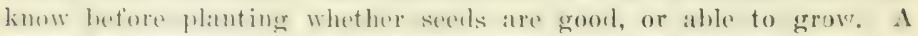
simple sedeltester may he mate of two plates, one inverted over the other (Fig. :31). The lower plate is nearly filled with elean sandi.

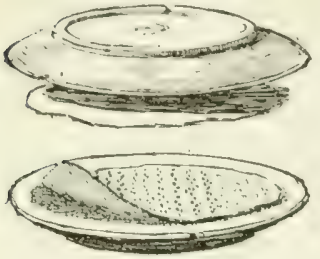

FIG. 3I.-A HOME-MADE SEED-TESTER. which is covered with cheese cloth or blotting paper on which the seeds are placed. Canton flannel is sometimes used in place of sand and blotting paper. The seeds are then corered with another blotter or piece of eloth, and water is applied until the sand and papers are saturated. Cover with the second plate. Set the plates where they will have about the temperature that the given seeds wonld require out of doors, or perhaps a slightly higher temperature. Place 100 or more grains of elover, corn, wheat, onts, rye, rice, buckwheat, or other seeds in the tester, and keep record of the number that sprout. The result will give a pereentage measure of the ability of the seeds to grow. Note whether all the seeds sprout with equal vigour and rapidity. Most seeds will spront in a week or less. I'sually such a tester must have fresh sand and paper after each test, for mould fungi are likely to breed in it. If eanton flannel is used, it may he boiled. If possible, the seeds should not touch one another.

Note to Teacher.-With the study of germination, the pupil will need to begin dissecting.

For dissecting, one neels a lens for the examination of the smaller parts of plants and animals. It is best to have the lens. momted on a frame, so that the pupil has both hands free for pulling the part in pieces. An ordinary pocket lens may be mounted on a wire in a block as in Fig. A. A cork is slipped on the tol of the wire to aroid injury to the face. The pupil should be provided with two dissecting needles (Fig. B), made by securing an ordinary nectle in a pencil-like stick. Another convenient arrangement is shomn in Fig. C. A small tin 'ish is used for the base. Into this a stiff wire standard is soldered. The dish is filled with solder to make it heary and firm. Into a cork slipred on the standard, a cross wire is inserted, holding on the end a jeweller's 
glass. The lens can be moved up and down and sidewise. This outfit can be made for about seventy-five cents. Fig. D shows a conrenient hand-rest or cissecting-stand to be used under this lens. It may be $16 \mathrm{in.}$ long, $4 \mathrm{in}$. high, and 4 or $5 \mathrm{in.} \mathrm{broad.}$

Various kinds of dissecting microseopes are on the market, and these are to be recommended when they can be afforded.

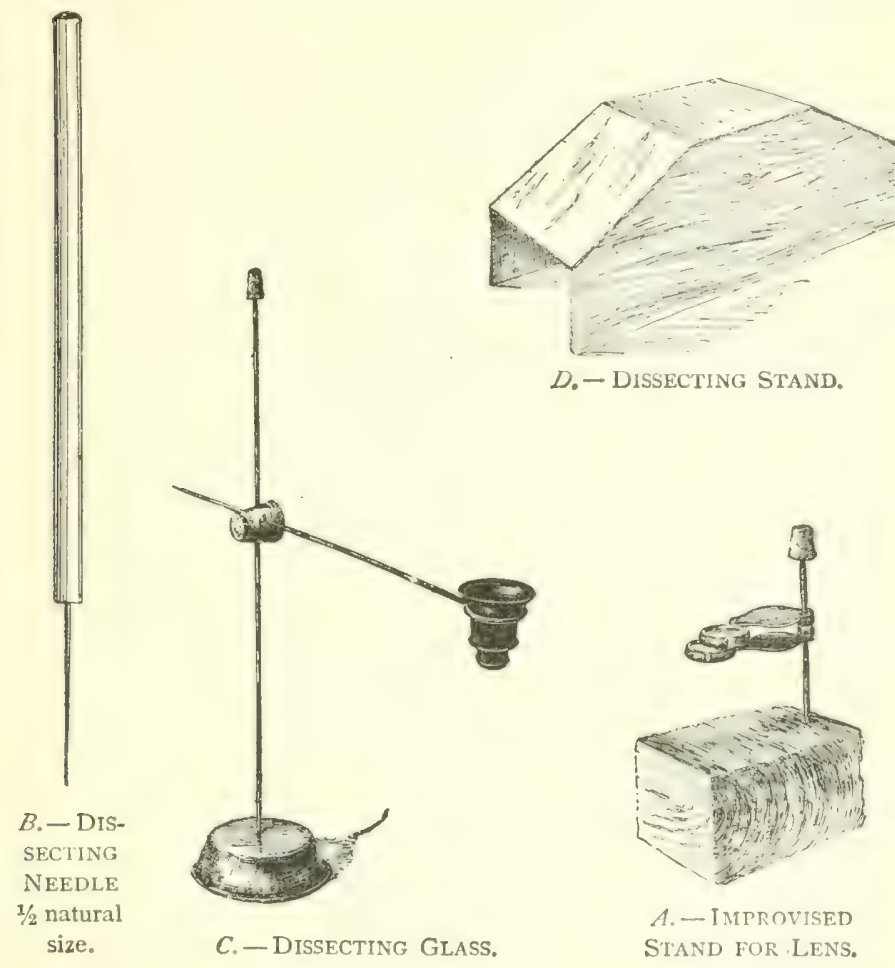

Instructions for the use of the compound microseope, with which some schools may be equipped, cannot be given in a brief splace; the technique requires careful training. Surh microsenges are not needed unless the pupil studies cells and tissues. 


\section{CHAPTER VII}

\section{THE ROOT - THE FORMS OF ROOTS}

The Root System. - The offices of the root are to hold the plant in pluce, and to gather fool. Not all the food materials, however, are gathered by the roots.

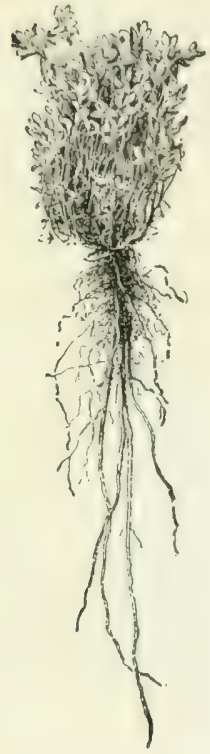

FIG. 32. - TAP-ROOT SYSTEM OF ALFALFA.

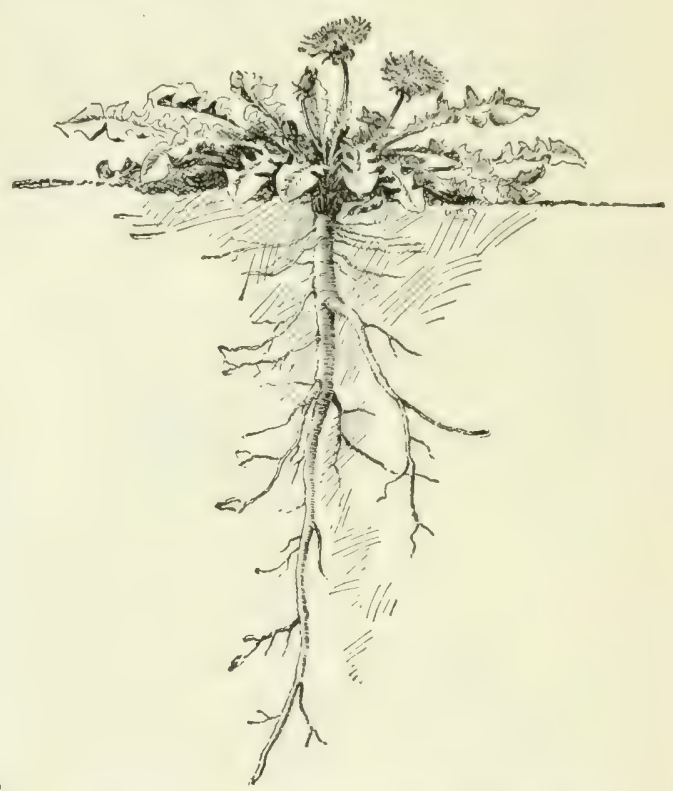

FIG. 33. - TAP-ROOT OF THE DANDELION.

The entire mass of roots of any plant is called its root system. The root system may be annual, biennial or perennial, herbaceous or woody, deep or shallow, large or small.

Kinds of Roots. - A strong leading central root, which runs directly downwards, is a tap-root. The tap-rout forms 
an axis from which the side roots may branch. The side or spreading roots are usually smaller. Plants that have such a root system are said to be tap-rooted. Examples are red clover, alfalfa, beet, turnip, radish, burdock, dandelion, hickory (Figs. 32, 33).

A fibrous root system is one that is composed of many nearly equal slender branches. The greater number of plants have fibrous roots. Examples are many common grasses, wheat, oats, corn. The buttercup in Fig. 34 has a fibrous root system. Many trees have a. strong tap-root when very young, but after a while it ceases to extend strongly and the side roots develop until finally the tap-root character disappears.

Shape and Extent of the Root System. - The depth to which roots

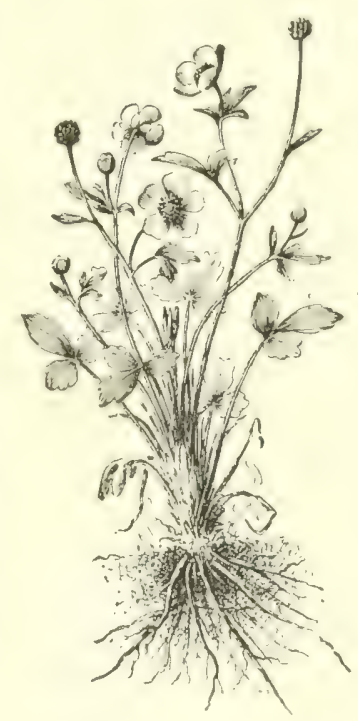

Fis. 34. - A Beitercup PlanT, with fibrous roots. extend depends on the kind of plant, and the nature of the soil. Of most plants the roots extend far in all dircctions and lie comparatively ncar the surface. The roots usually radiate from a common point just beneath the surface of the ground.

The roots grow here and there in scarch of food, often cxtending much farther in all directions than the spread of the top of the plant. Roots tend to spread farther in poor soil than in rich soil, for the same size of plant. The root has no such definite form as the stem has. Roots are usually very crooked, because they are constantly turned aside by obstacles. Examine roots in stony soil. 


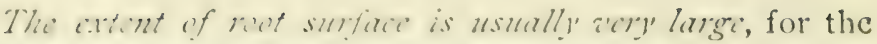
feeding reots are fine and very numerous. An ordinary plant of Indian corn may have a total length of root (measured as if the roots were placed end to end) of several hundred feet.

The fine feeding ronts are most abundint in the riclust pirt if the soil. 'They are attracted by the food materials. Roots often will completely surround a bone or other morsel. When roots of trees are exposed, observe that most of them are horizontal and lie near the top of the ground. Some roots, as of willows, extend far in siaris of wieter. They often run into wells and drains, and into the margins of creeks and ponds. Grow plants in a long narrow box, in one end of which the soil is kept very dry and in the other moist: observe where the roots grow.

Buttresses. - With the increase in diameter, the upper roots often protrude above the ground and become bracing buttresses. These buttresses are usually largest in trees

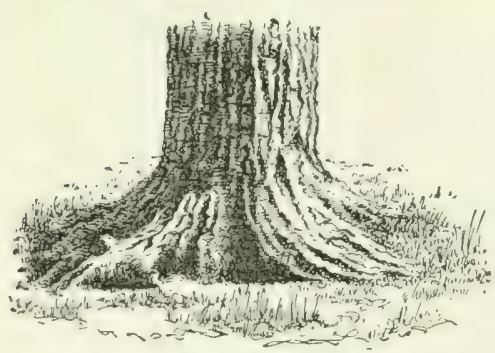

Fig. 35. - The BRACING BASE OF A FIELD PINE. which always have been exposed to strong winds (Fig. 35). Because of growth and thickening, the roots elevate. part of their diameter, and the washing away of the soil makes them to appear as. if having risen out of the ground.

Aërial Roots. - Although roots usually grow underground, there are some that maturilly grow abor'c ground. These usually occur on climbing plants, the roots becoming supforts or fulfilling the office of tendrils. These aërial roots usually tum away from the light, and therefore enter the 
crevices and dark places of the wall or tree over which the plant climbs. The trumpet crecper (Fig. 36 ), truc or

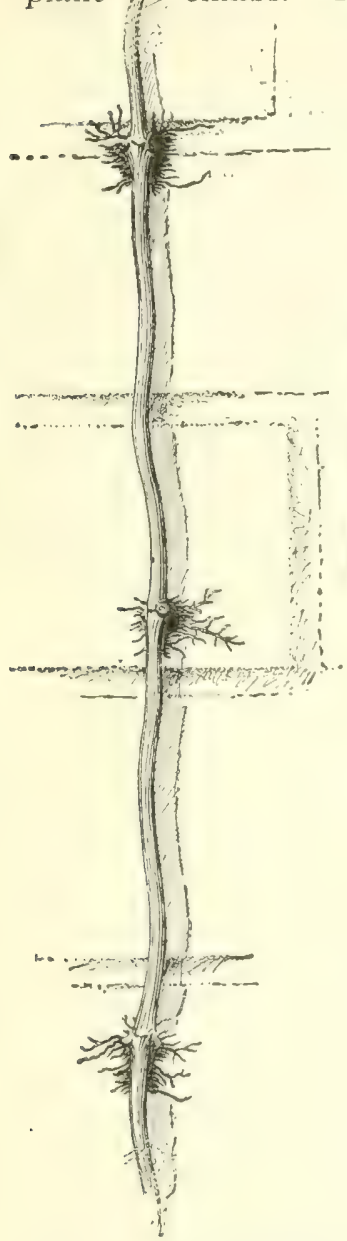

Fis. 36. - Ä̈RIAL RoOTS

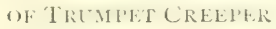
or lecoms.
English ivy, and poison ivy climb by

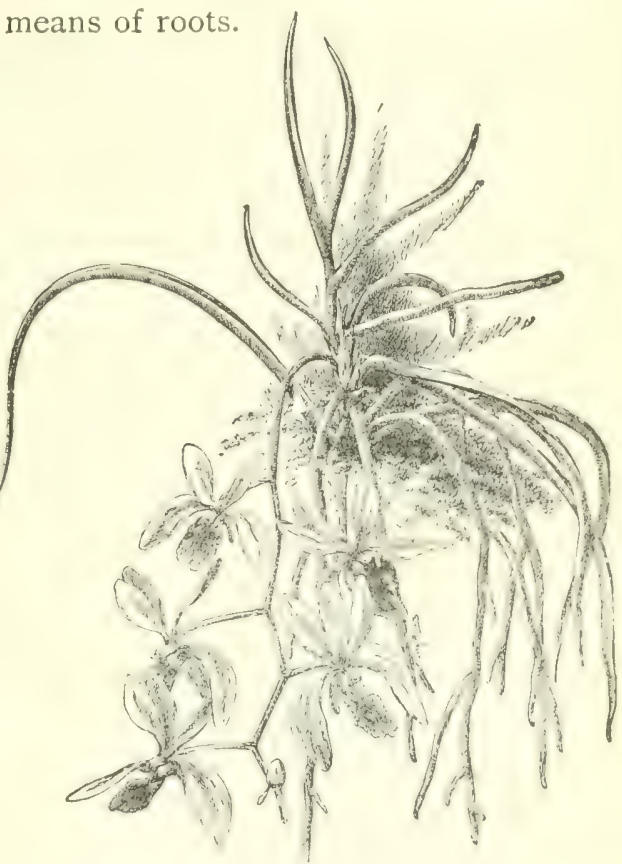

FIG. 37.-AiRIAL ROOTS OF AN ORCHID.

In some plants all the roots are aërial; that is, the piant growes above ground, and the roots gather food from the air. Such plants usually grow on trees. They are known as epiphytes or air-plants. The most familiar examples are some of the iropical orchids which are grown in glasshouses (Figr. 37). Rootlike organs of cludder and other parasites are discussed in a future chapter. 
Some plants bear aërial roots, that may fropagate tho plant or may act as bracis. They are of ten called prop-roots. The roots of Indian corn are familiar (Fig. 38). Many ficus trees, as the banyan of India, send out roots from their branches; when these roots reach the ground they take hold and become great trunks, thus spreading the

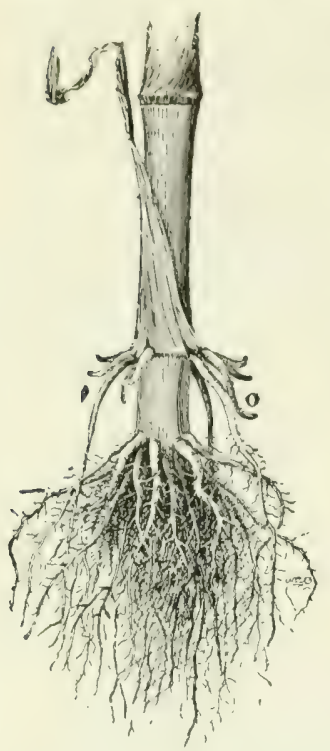

FIG. 38. - INDIAN CORN, showing the brace roots at 00 . top of the parent tree over large areas. The mangrove tree of the tropies grows along seashores and sends down roots from the overhanging branches (and from the fruits) into the shallow water, and thereby gradually marches into the sea. The tangled mass behind catehes the drift, and soil is formed.

Adventitious Roots.- Sometimes roots grow from the stem or other unusual places as the result of some accident to the plant, being located without known method or law. They are called adventitious (chance) roots. Cuttings of the stems of roses, figs, geraniums, and other plants, when planted, send out adventitious roots and form new plants. The ordinary roots, or soil roots, are of course not classed as adventitious roots. The adventitious roots arise on occasion, and not as a normal or regular course in the growth of the plant.

No two roots are alike; that is, they vary among themselves as stems and leaves do. Each lind of plant has its 
ocen form or habit of root (Fig. 39). Carefully wash away the soil from the roots of any two related plants, as oats and wheat, and note the differences in size, depth, direction, mode of branching, number of fibrils, colour, and other
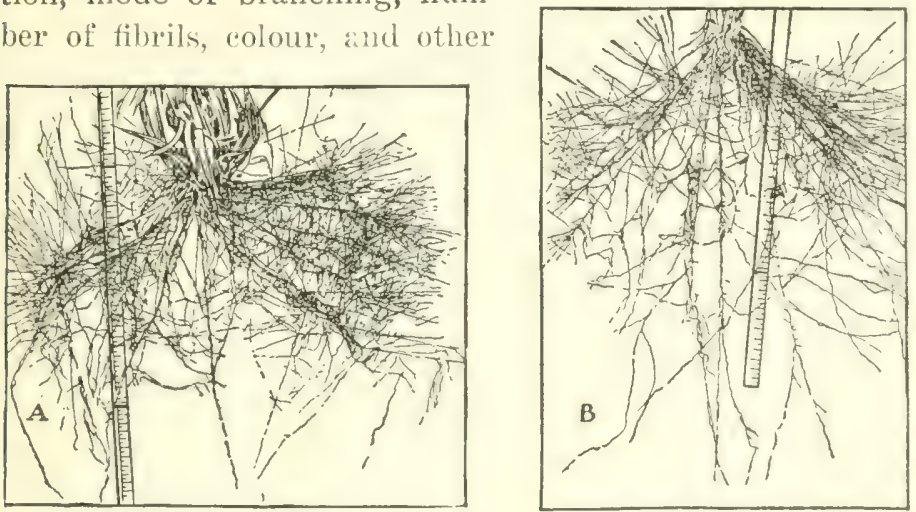

FIG. 39. - ROOTS OF BARIEY AT $A$ AND CORN AT $B$. Carefully trace the differences.

features. The character of the root system often governs the treatment that the farmer should give the soil in which the plant or crop grows.

Roots differ not only in their form and habit, but also in colour of tissue, chararter of bark or rind, and other features. It is excellent pratetion to lry to ide ntify different plants by moanis of the it mels. Let each pupil hring to school two plants with the roots very arefully dug up, as rotton, rorn, potato, hean, wheat, rye, timothy, pumpkin, clover, sweet pea, raspherry, straterery, or other common plants.

Root Systems of Weeds. - Some weeds are pestiferous because they seed abundantly, and others because their underground parts run deep or far and are persistent. Make out the root systems in the six worst weeds in your locality. 


\section{CHAPTER VIII}

\section{THE ROOT. - FUNCTION AND STRUCTURE}

Tine function of roots is twofold, - to provide support or anchorage for the plant, and to collect and convey food materials. The first function is considered in Chapter VII; we may now give attention in more detail to the second.

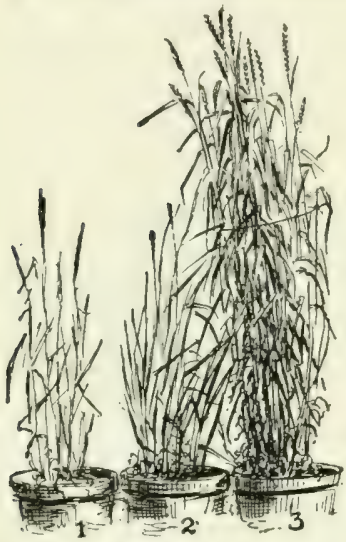

Fig. 40.-WHEAT GROWING

UNUER DIFFERENT SOIL TREATMENTS. Soil deficient in nitrogen; commercial nitrogen applied to pot 3 (on right).

The feeding surface of the roots is near their cnds. As the roots become old and hard, they serve only as channels through which food passes and as hold-fasts or supports for the plant. The roothold of a plant is very strong. Slowly pull upwards on some plant, and note how firmly it is anchored in the soil.

Roots have power to choose their food; that is, they do not absorb all substances with which they come in contact. They do not take up great quantities of useless or harmful materials, even though these materials may be abundant in the soil; but they may take up a greater quantity of some of the plant-foods than the plant can use to advantage. Plants respond vory quickly to liberal fecding, - that is, to the application of plant-food to the soil (Fig 40). The poorer the soil, the more marked are the results, as a rule, of the application 
of fertilizers. Certain substances, as common salt, will kill the roots.

Roots absorb Substances only in Solution. - Substances cannot be taken in solid particles. These materials are in solution in the soil water, and the roots themselves also have the power to dissolve the soil materials to some extent by means of substances that they excrete. The materials that come into the plant through the roots are watcr and mostly the mincral substances, as compounds of potassium, iron, phosphorus, calcium, magnesium, sulphur, and chlorine. These mineral substances compose the ash when the plant is burned. The carbon is derived from the air through the green parts. Oxygen is derived from the air and the soil water.

Nitrogen enters through the Roots. - All plants must have nitrogen;

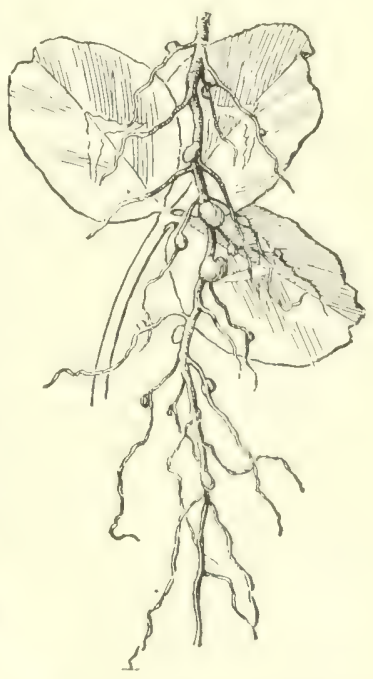
yet, althongh ahout four-fifths of Fig.4I- Nonules on Roots the air is nitrogen, plants are not OF RED LLLOVER. able, so far as we know, to take it in through their leaves. It enters through the roots in combination with other ele. ments, chiefly in the form of nitrates (certain combinations with oxygen and a mineral base). The great family of leguminous plants, however (as peas, beans, cowpea, clover, alfalfa, vetch), use the nitrogen contained in the air in the soil. They are able to utilize it through the agrncy of nodules on their roots (Figs. 4I, 42). These nodules contain bacteria, which appropriate the free or uncombined nitrogen and pass it on to the plant. The nitrogen 
becomes incorporated in the plant tissue, so that these crops are high in their nitrogen content. Inasmuch as

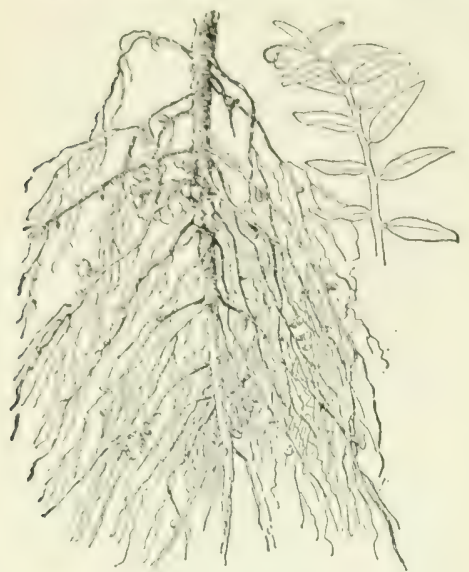

FIG. 42. - NODULES ON VETCH. nitrogen in any form is expensive to purchase in fertilizers, the use of leguminous erops to plough under is a very important agricultural practice in preparing the land for other crops. In order that leguminous crops may aequire atmospheric nitrogen more freely and thereby thrive better, the land is sometimes sown or insculated with the nodule-forming bacteria.

Roots require moisture in order to serve the plant. The soil water that is valuable to the plant is not the free water, but the thin fim of moisture which adheres to each little particle of soil. The finer the soil, the greater the number of particles, and therefore the greater is the quantity of film moisture that it can hold. This moisture surrounding the grains may not be perceptible, yet the

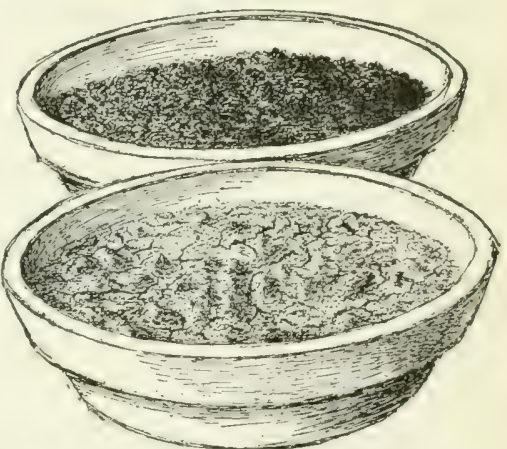

FIG. 43. - TwO KINDS OF SOIt, THAT HAVE BEEN WET AND THEN DRIED. The loamy soil above remains loose and capable of growing plants; the clay soil below has baked and cracked.

plant can use it. Root absorption may continue in a soil which seems to be dust diy. Soils that are very hard and 
"baked" (Fig. 43) contain very little moistrue or air, not so much as similar soils that are granular ur mellow.

Proper Temperature for Root Action. - The root must be warm in order to perform its functions. Should the soil of fields or greenhouses be much colder than the air, the plant suffers. When in a warm atmosphere, or in a dry atmosphere, plants need to absorb much water from the soil, and the roots must be warm if the root-hairs are to supply the water as rapidly as it is needed. If the roots are chilled, the plant may wilt or die.

Roots need Air. - C : n on land that has been flooded by heavy rains loses its green "olour and turns yellow. Besides diluting plant-food, the watcr driacs the air from the soil, and this suffocation of the roots is vcry soon apparent in the gencral ill health of the plant. Stirring or tilling the soil aerates it. Water plants and bog plants have adapted themselves to their particular conditions. They get their air either by special surface roots, or from the water through stems and leaves.

Rootlets. - Roots divide into the thimest and finest fibrils: there are roots and there are rootlets. The smallest rootlets are so slender and delicate that they break off even when the plant is very carefully lifted from the soil.

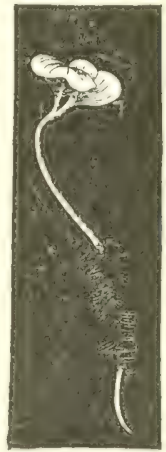

FIG. 44. - RIOT. IIAIRS OF THE RADISH.

The rootlcts, or fine divisions, are clothed with the roothairs (Figs. 44, 45, 46). These root-luirs attich to the soil particles, and a great amount of soil is thus brought into actual contact with the plant. These are very dilicate prolonged surface cells of the roots. They are borne for a short distance just back of the tip of the root.

Rootlit and reot-luair differ. The rootlet is a compact 
collular structure. The root-har is a delicate mululur cill (Fig. 45), within which is containd liaing matter (froteplasm); and the protoplasmic lining membranc of the

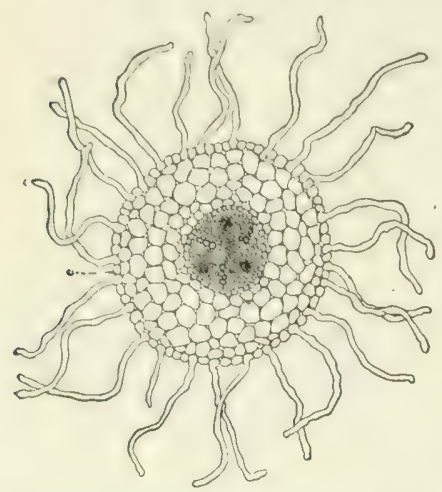

Fig. 45. - CRnSS-SEITION OF Root, enlarged, slowing root-hairs. wall governs the cutrance of watcr and substances in solution. Being long and tubelike, these root-hairs are especially adapted for taking in the largest quantity of solutions; and they are the principal means by which plant-food is absorbed from the soil, although the surfaces of the rootlets themselves do their part. Water plants do not produce an abundant system of root-hairs, and such plants depend largely on their rootlets.

The root-hairs are very small, often invisible. They, with the young roots, are usually broken off when the plant is pulled up. They are best seen when seeds are germinated between layers of dark blotting paper or flannel. On the young roots they will be seen as a mould-like or gossamerlike covering. Root-hairs soon dic: they do not grow into roots. New ones form as the root grows.

Osmosis. - The water with its nourishment goes through the

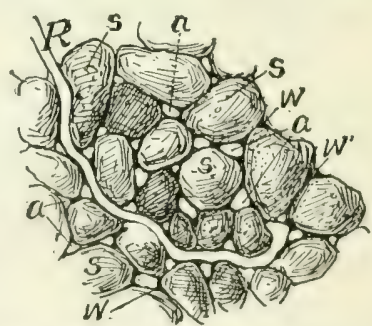

FIG. 46. - ROOT-HAIR, muchenlarged, in contact with the soil particles $(s)$. Air-spaces at $a$; water-films on the particles, as at $w$.

thin walls of the root-hairs and rootlets by the process of osmosis. If there are two liquids of different density 
on the inside and outside of an organic (either vegetable or animal) membrane, the liquids tend to mix through the membrane. The law of osmosis is that the most rapid flow is toward the dinser solution. The protoplasmic lining of the cell wall is such a membrane. The soil water being a weaker solution than the sap in the roots, the flow is into the root. A strong fertilizer sometimes causes a plant to wither, or "burns it." Explain.

Structure of Roots. - The root that grows from the lower end of the caulicle is the first or primary root. Secondary roots branch from the primary root. Branches of secondary roots are sometimes called tertiary roots. Do the secondary roots grow from the cortex, or from the central cylinder of the primary root? Trim or peel the cortex from a root and its branches and determine whether the branches still hold to the central cylincler of the main root.

Internal Structure of Roots. - A section of a root shows that it consists of a central cylinder (see Fig. 45) surrounded by a layer. This layer is called the cortex. The outer layer of cells in the cortex is called the epidermis, and some of the cells of the epidermis are prolonged and form the delicate root-hairs. The cortex resembles the bark of the stem in its nature. The central cylinder contains many tube-like canals, or "vessels" that convey water and food (Fig. 45). Cut a sweet potato across (also a radish and a turnip) and distinguish the central cylinder, cortex, and epidermis. Notice the hard cap on the tip of roots. Roots differ from stems in having no real pith.

Microscopic Structure of Roots. - Near the end of any young root or shoot the rells are found to differ from one another more or less, according to the distance from the point. This differcntiation takes place in the region just back of the growing point. To study growing points, use 
the hypocotyl of Indian corn which has grown about onehalf inch. Make a longitudinal section. Note these points (Fig. 47): (a) the tapering root-cap beyond the growing point; (b) the blunt end of the root proper and the rectangular shape of the cells found there; (c) the group of cells in the middle of the first layers beneath the root-

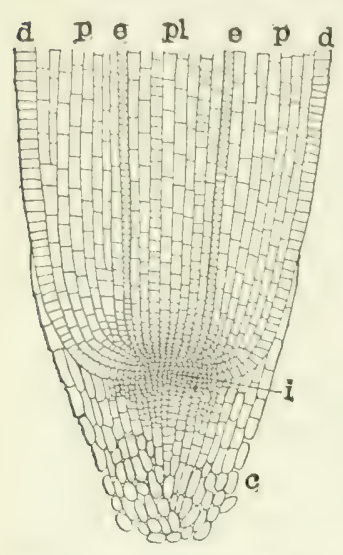

FIG. 47.-GROWING POINT OF ROOT OF INDIAN CORN. $d, d$, cells which will form the epidermis; $p, p$, cells that will form bark; $f, e$, endodermis; $p l$, cells which will form the axis cylinder; $i$, initial group of cells, or growing point proper; $c$, root-cap. cap, - this group is the growing point; (d) study the slight differences in the tissues a short distance back of the growing point. There are four regions : the central cylinder, made up of several rows of cells in the centre $(p l)$; the endodermis, $(c)$ composed of a single layer on each side which separates the central cylinder from the bark; the cortex, or inner bark, (e) of several layers outside the endodermis; and the epidermis, or outer layer of bark on the outer edges (d). Make a drawing of the section. If a series of the cross-sections of the hypocotyl should be made and studied by the pupil beginning near the growing point and going upward, it would be found that these four tissues become more distinctly marked, for at the tip the tissues have not yet assumed their characteristic form. The central cylinder contains the ducts and vessels which convey the sap.

The Root-cap. - Note the form of the root-cap shown in the microscopic section drawn in Fig. 47. Growing cells, and especially those which are forming tissue by subdividing, are very delicate and are easily injured. The 
cells forming the root-cap are older and tougher and are suited for pushing aside the soil that the root may penetrate it.

Region of most Rapid Growth. - The roots of a seedling bean may be marked at equal distances by waterproof ink or by bits of black thread tied moderately tight. The seedling is then replanted and left undisturbed for two days.

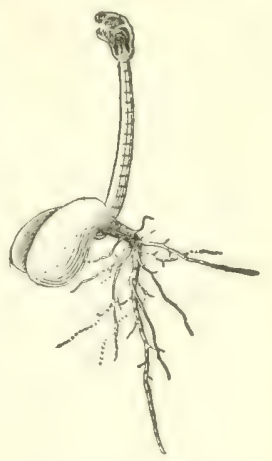
When it is dug up, the region of most

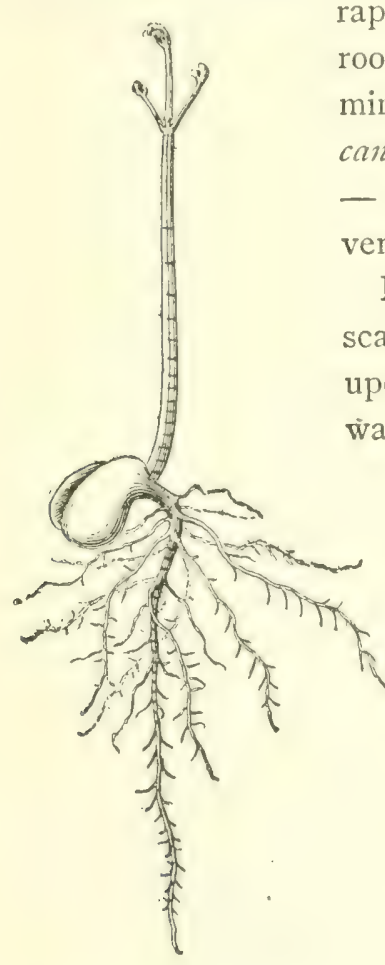

FIG. 49.-ThE REsUlT. rapid growth in the root can be deter-

Fig. 48. -THE MARKING OF THE STEM AND ROOT.

mined. Give a reason why a root cannot elongate throughout its length, - whether there is anything to prevent a young root from doing so.

In Fig. 48 is shown a germinating scarlet runner bean with a short root upon which are marks made with waterproof ink; and the same root (Fig. 49) is shown after it has grown longer. Which part of it did not lengthen at all? Which part lengthened slightly? Where is the region of most rapid growth?

Geotropism. - Roots turn toward the earth, even if the seed is planted with the micropyle up. This phenomenon is called positive geotropism. Stems grow away from the earth. This is negative geotropism. 
Sumistons (Chaps. VII and VIII).-25. Tists for fond. Fxamine a number of roots, including several fleshy roots, for the presence of food material, making the tests used on seeds. 26. Studl of reothrirs. Cirefully germinate ridlish, turnip, cabbage, or other seed, so that no delicate parts of the root will be injured. For this purpose, place a few seeds in packing-moss or in the folds of thick cloth or of blotting paper, being careful to keep them moist and war... In a few days the seed has germinated, and the root has stown an inch or two long. Notice that, except at a distance of about a quarter of an inch behind the tip, the root is covered with minute hairs (lig. 44). 'Ihey are actually hairs; that is, root-hairs. Touch them and they collapse, they are so delicate. I)ip one of the plants in water, and when removed the hairs are not to be seen. The water mats them together along the root and they are no longer evident. Root-hairs are usually destroyed when a plant is pulled out of the soil, be it done ever so carefully. 'They cling to the minute particles of soil (Fig. 46). The hairs show best against a dark background. 27. On some of the blotting papers, sprinkle sand; observe how the root-hairs cling to the grains. Observe how they are flattened when they come in contact with grains of sand. 28. Root

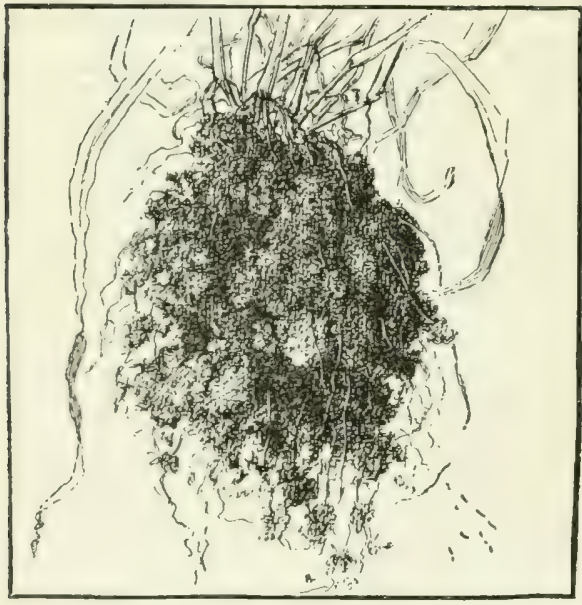

Fig. 50.--The Grasp of a Piant on the PartiCLES OF EARTH. A grass plant pulled in a garden. hold of plant. The pupil should also study the root hold. Let him carefully pull up a plant. If a plant grow alongside a fence or other rigid object, he may test the root hold by securing a string to the plant, letting the string hang over the fence, and then adding weights to the string. Will a stake of similar size to the plant and extending no deeper in the ground have such firm hold on the soil? What holds the ball of earth in Fig. 5o?

29. Rocts cxert pressure. Place a strong bulb of hyacinth or daffodil on firm-packed earth in a pot; cover the bulb nearly to the top with loose earth; place in a cool cellar; after some days 
or weeks, note that the bulb has been raised out of the earth by the forming roots. All roots exert pressure on the soil as they grow. Explain. 30. Response of roots and stems to the force of gratitl', or geotropism. Plant a fast-growing seedling in a pot so that the plumule extends through the drain hole and suspend the pot with mouth up (i.e. in the usual position). Or use a pot in which a plant is already growing, cover with cloth or wire gauze to prevent the soil from falling, and suspend the pot in an inverted position (Fig. $5 \mathrm{I}$ ). Notice the behaviour of the stem, and after a ferv days remove the soil and observe the position of the root. 31. If a pot is laid on one side, and changed every two days and laid on its opposite side, the effect on the root and stem will be interesting. 32. If a fleshy root is planted wrong end up, what is the result? Try it with pieces of horse-radish root. 33. By planting radishes on a slowly revolving wheel the effect of gravity may be neutralized. 34. Rerion of

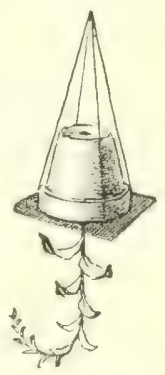

FIG, 51.-

PIANT GROLVINC; IN INVERTED POT. root most sensitize to gravity. Lay on its side a pot containing a growing plant. After it has grown a few days, wash away the earth surrounding the roots. Which turned downward most decidedly, the tip of root or the upper part? 35. Soil texture. Carefully turn up soil in a rich garden or field so that you have unbroken lumps as large as a hen's egg. 'Then break these lumps apart carefully

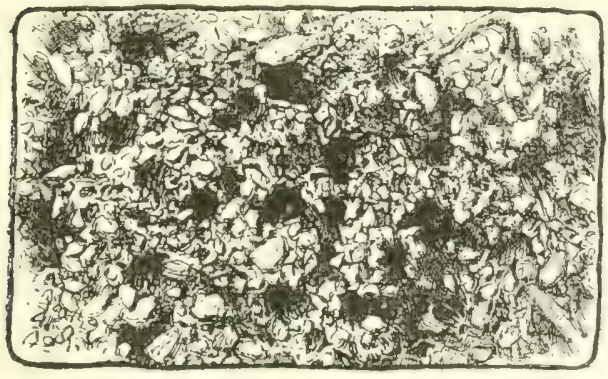

FiG. 52.-Holes IN SOIL MADE BY ROOTS, now decayed. Somewhat magnified. with the fingers and determine whether there are any traces or remains of roots (Fig. 52). Are there any pores, holes, or channels made by roots? Are the roots in them still living? 36. Compare another lump from a clay bank or pile where no plants have been growing. Is there any difference in texture? 37. Grind up this clay lump very fine, put it in a saucer, cover with water, and set in the sun. After a time it will have the appearance shown in the lower saucer in Fig. 43 . Compare this with mellow garden soil. In which will plants grow best, even if the plant-food were the same in both? Why? 38. To test the effect of moisture on the plant, let a plant in a pot or box dry 
out till it wilts; then ald water and note the rapidity with which it recovers. Vary the experiment in guantity of water applied. Does the plant call for water sooner when it stands in a sunny window than when in a cool shady place? l'rove it. 39. Immerse a potted plant above the rim of the pot in a pail of water and let it remain there. What is the consequence? Why? 40. To test the effict of temperature on roots. l'ut one pot in a dish of ice water, and another in a dish of warm water, and keep them in a warm room. In a short time notice how stiff and vigorous is the one whose roots are warm, whereas the other may show signs of wilting. 41. The process of osmosis. Chip away the shell from the large end of an egg so as to expose the uninjured membrane beneath for an area about as large as a ten-eent piece. With sealingrwax, chewing-gum, or paste, stick a cunill ahont three inches long to the smaller end of the egg. After the tube is in place, run a hat pin into it so as to pierce both shell and membrane; or use a short glass tube, first scraping the shell thin with a knife and then boring through it with the tube. Now set the egg upon the mouth of a pickle jar nearly full of water, so that the large end with the exposed membrane is beneath the water. After several hours, observe the tube on top of the egg to see whether the water has forced its way into the egg and increased its volume so that part of its contents are forced up into the tube. If no tube is at hand, see whether the contents are forced through the hole which has been made in the small end of the egg. Explain how the law of osmosis is verified by your result. If the eggshell contained only the membrane, would water rise into it? If there were no water in the bottle, would the egg-white pass down into the bottle? 42. The region of most rapid growoth. The pupil should make marks with waterproof ink (as Higgins' ink or indelible marking ink) on any soft growing roots. Place seeds of bean, radish, or cabbage between layers of blotting paper or thick cloth. Keep them damp and warm. When stem and root have grown an ineh and a half long each, with waterproof ink mark spaces exactly one-quarter inch apart (Figs. 48, 49). Keep the plantlets moist for a day or two, and it will be found that on the stem some or all of the marks are more than one-quarter inch apart; on the root the marks have not separated. The root has grown beyond the last mark. 


\section{CHAPTER IX}

\section{THE STEM - KINDS AND FORMS ; PRUNING}

The Stem System. - The stem of a plant is the part that bears the buds, lcaics, flowers, and fruits. Its office is to hold these prerts up to the light and the air: and through its tissues the various food-materials and the lifegiving fluids are distributed to the growing and worting parts.

The entire mass or fabric of stems of any plant is called its stem system. It comprises the trunk, branches, and twigs, but not the stalks of leaves and flowers that die and fall away. The stem system may be herbaceous or woody, annual, biennial, or perennial; and it may assume many sizes and shapes.

Stems are of Many Forms. - The general way in which a plant grows is called its habit. The habit is the appcar: ance or scneral form. Its habit may be open or loose, dense, straight, crooked, compact, straggling, climbing, crect, weak, strong, and the like. The roots and the leaves are the important functional or working parts; the stem merely connects them, and its form is exceedingly variable.

Kinds of Stems. - The stim may' be so short as to bc scarcely distingrishable. In such cases the ciown of the plant - that part just at the surface of the ground - bears the leaves ant the flower's; hut this crown is really a very short stem. The dandelion, Fig. 33, is an example. Such plants are often said to be stemless, however, in order to distinguish them from plants that have long or conspic- 
uous stems. These sorallid stimliss plants dic to the ground every jear.

Stems are erect when they grow straight up) (liigs. 53, 54). They are trailing when they run along on the ground,

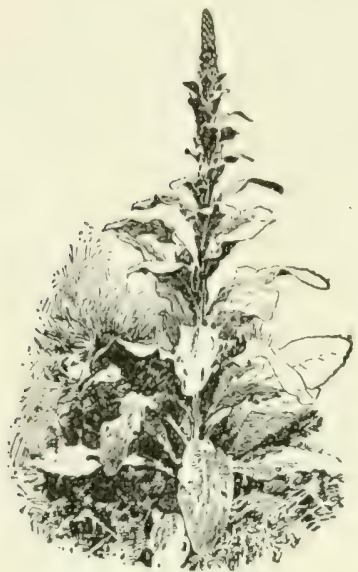

FIG. 53. - STRICT Simple STEM of Mullein.

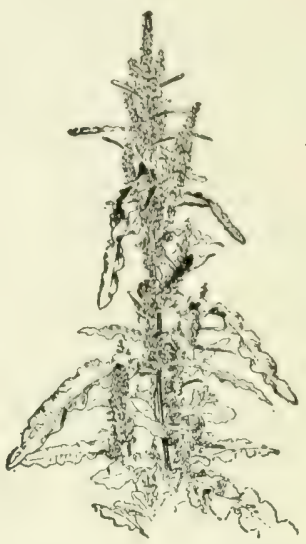

Fig. 54. - STRICT UPRIGHT STEM OP NARROW-LEAVED DOCK.

as melon, wild morning-glory (Fig. 55). They are,creeping when they run on the ground and take root at places,

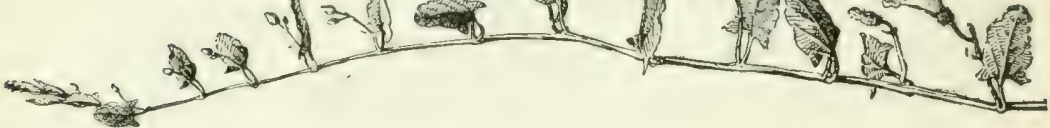

Fig. 55. - Trailing Stem of Wild Morning Gloky (Convolvulus arvensis).

as the strawberry. They are decumbent when they lop over to the ground. They are ascending when they lie mostly or in part on the ground but stand more or less upright at their ends; example, a tomato. They are 
climbing when they cling to other objects for support (Figs. 36, 56).

Trees in which the main trunk or the "leader" continues to grow from its tip are said to be excurrent in growth. The branches are borne along the sidcs of the trunk, as in common pines (Fig. 57) and spruces. Excurrent means ranning out or running up.

Trees in which the main trunk does not continue are said to be deliquescent. The branches arise from one common point or from cach other. The stem is lost in the branches. The apple tree, plum (Fig. 5\&), maple, elm, oak, China tree, are familiar examples. Deliquescent means dissolving or melting away.

Each kind of plant has its own peculiar habit or direction of growth. Spruces always grow to a single stem or trunk, pear

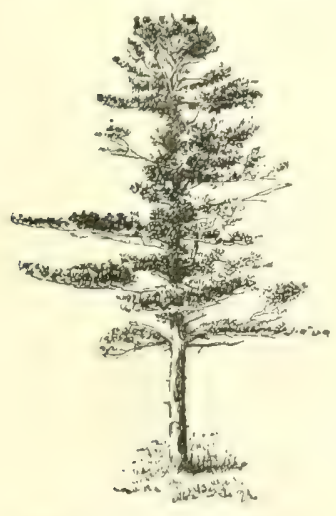

FIG. 57.- EXCURRENT

TRUNK. A pine.

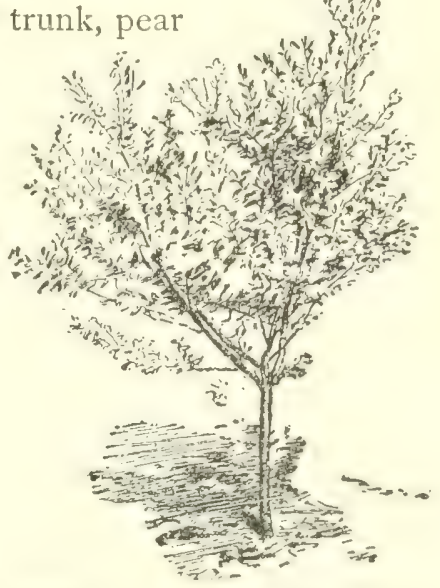

Fig. 58.- DELIQUescent TRUNK of Plum TREe. 
trees are always deliquescent, morning-glories are always trailing or climbing, strawberries are always creeping. We do not know why each plant has its own habit, but the habit is in some way associnted avith the plant's gronealogry or with the arey in which it has bicn obliged to liac.

The stem may be simple or branched. A simple stem usually grows from the terminal bud, and side branches either do not start, or, if they start, they soon perish. Mulleins (Fig. 53) are usually simple. So are palms.

Branched stems may be of a'cry differcnt habit and shape: Some stem systems are narrow and erect; these are said to be strict (Fig. 54). Others are diffusi, open, branchy, twiggy.

Nodes and Internodes.-The parts of the stem at which buds grow are called nodes or joints and the spaces between the buds are internodes. The stem at nodes is usually enlarged, and the pith is usually interrupted. The distance between the nodes is influenced by the vigour of the plant: how?

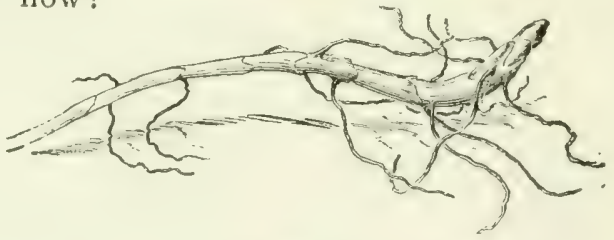

FIG. 59. - RHIZOME OR ROOTSTOCK.

Stems vs. Roots. - Roots sometimes grow above ground (Chap. VII); so, also, stcms sometimes grow undcrground, and they are then known as subterranean stems, rhizomes, or rootstocks (Fig. 59).

Stems normally bear leaves and buds, and thereby are they distinguished from roots; usually, also, they contain a pith. The leaves, however, may be reduced to mere scales, and the buds beneath them may be scarcely visible. 
Thus the "eyes" on a white potato are cavities with a bud or buds at the bottom (Fig. 60). Sweet potatoes have no evident "eyes" when first dug, (but they may develop adventitious buds before the next growing-season). The white potato is a stem : the sweet potato is probably a root.

How Stems elongate. - Roots elongate by growing near the tip. Stcms clongate by growing more or lcss throughout the young or soft part or "between joints" (Figs. 48, 49). But any part

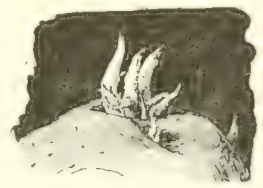

Fig. 60. - SPROUTS ARISING FROM THE Buns, or eyes, of a potato tuber. of the stem soon reaches a limit beyond which it cannot grow, or becomes "fixed"; and the new parts beyond elongate until they, too, become rigid. When a part of the stem once becomes fixed or hard, it never increases in length: that is, the trink or woody parts neicr growe longer or higher; branchis do not become firther apert or higher from the ground.

Stems are modified in form by the particular or incidental conditions under which they grow. The struggle for light is the chief factor in determining the shape and the direcetion of any limb ('halp. II). This is well illustrated in any tree or bush that grows against a building or on the margrin of a forest (Fig. 4). In a very dense thicket the innermost trees shoot up over the others or they perish. Examine any stem and endearour to determine why it took its particular form.

The stem is cylindrical, thic outer part boing bork and the inner part bing wood or woody tissuc. In the dicotyledonous plants, the bark is usually easily separated from the remainder of the cylinder at some time of the year; in monocotyledonous plants the bark is not free. Growth in thickness takes place inside the covering and not on the very 
nitside of the plant cylinder. It is evident, then, that the covering of hark must expand in order to allow of the expan-

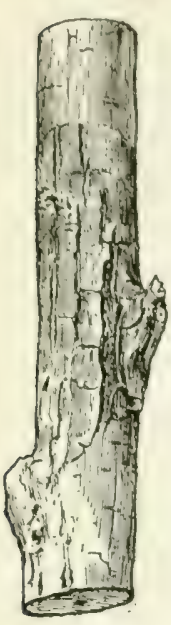

Fig. 6I.CRACKING OF THE

BARK ON AN

ELM

BRANCH. sion of the woody cylinder within it. The tissues, therefore, must be under constant pressure or tension. It has been determined that the pressure within a growing trunk is often as much as fifty pounds to the square inch. The lower part of the limb in Fig. 6I shows that the outer layers of bark (which are long since dead, and serve only as protective tissue) have reached the limit of their expanding capacity and have begun to split. The pupil will now be interested in the bark on the body of an old elm tree (Fig. 62); and he should be able to suggest one reason why stems remain cylindrical, and why the old bark becomes marked with furrows, scales, and plates.

Most woody plants increase in diameter by the addition of an anmal layer or "ring" on the outside of the woody cylinder, underneath the bark. The monocotyledonous plants comprise very few trees and shrubs in temperate climates (the palms, yuccas, and other tree-like plants are of this class), and they do not increase greatly in diameter and they rarely branch to any extent.

Bark-bound Trees.-If, for any reason. the bark should become so dense and strong that the trunk cannot expaind, the tree is said to be "bark-bound."

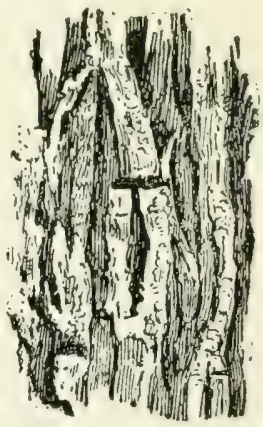

FIG. 62。- PIECE OF BARK FROM AN Old Elm TRUNK. Such endition is not rare in orchard trees that have been neglected. Whein good tillage is given tc such trees, they 
may not be able to overeome the rigidity of the oid bark, and, therefore, do not respond to the treatment. Sometimes the parts with thimmer hark may outgrow in diameter the trunk or the old branches below them. The remedy is to rilcase the tension. This may be done either by softening the bark (by washes of soap or lye), or by separating it. The latter is done by slitting the bark-bound part (in spring), thrusting the point of a knife through the bark to the wool. and then drawing the blade down the entire length of the barkbound part. The slit is scarcely discernible at first, but it opens with the growth of the tree, filling up with new tissue beneath. Let the pupil consider the ridges which he now and then finds on trees, and determine whether they have any significance - whether the tree has ever been released, or injured by natural agencies.

The Tissue covers the Wounds and "heals" them.

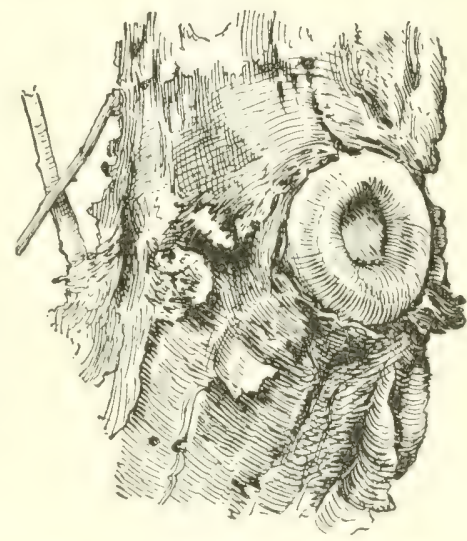

Fir, 63. - Proper CiTTINe; OF A BRAvir. The wound will soon be "healed,"

- This is seen in Fig. 63, in which a ring of tissue rolls out over the wound. This ring of healing tissue forms most rapidly and uniformly when the wound is smooth and regular. Observe the healing on broken and splintered limbs; also the difference in rapidity of healing between wounds on strong and weak limbs. There is a difference in the rapidity of the healing process in different kinds of trees. Compare the apple tree and the peach. This tissue may in 
turn become bark-boind, and the healing may stop. On large wounds it progresses more rapidly the first few years

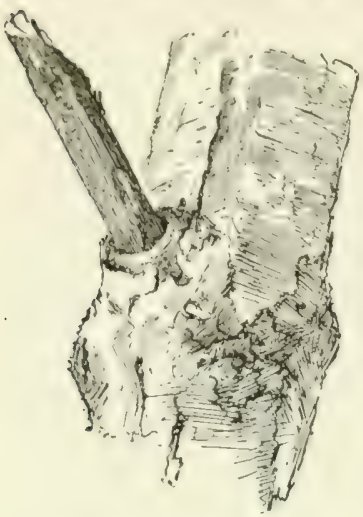

Fig. 64. - FRRONFUL'S

PRUNING. than it does later. This roll or ring of tissue is called a callus.

The callus grows from the living tissue of the stem just about the wound. It cannot cover long dead stubs or very rough broken branches (Fig. 64). Therefore, in pruning the branches should be cut close to the trunk and made even and smooth; all long stubs must be aroided. The seat of the wound should be close to the living part of the trunk, for the

stub of the limb that is severed has no further power in itself of making healing tissue. The end of the remaining stub is merely covered over by the callus, and usually remains a dead piece of wood sealed inside the trunk (Fig. 65). If wounds do not heal over speedily, germs and fungi obtain foothold in the dying wood and rot sets in. Hollow trees are those in which the decayfungi have progressed into the inner wood of the trunk; they have been infected (Fis. 66).

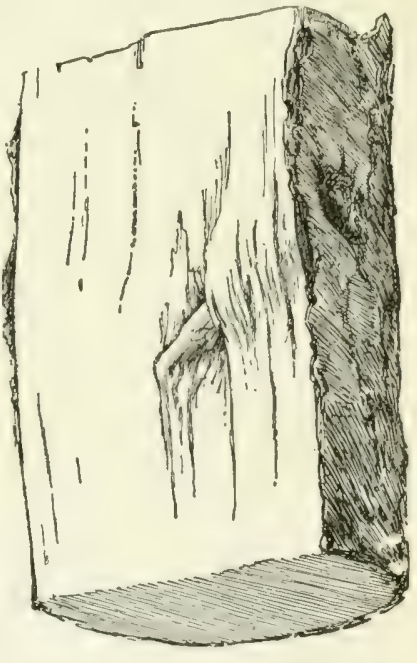

FIG. 65.-KNOT IN A HEMLOCK LOG.

Large wouuds snould be protected with a covering of paint, melted wax, or other adhesive and lasting material, 


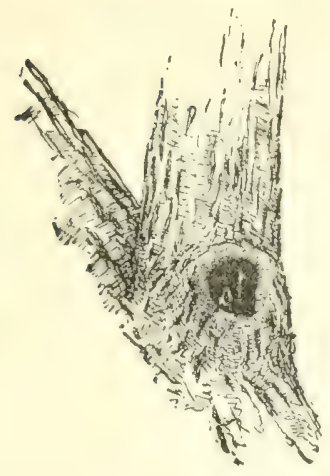

FIG. 66.-A KNOT HOLE, and the beginning of a hollow trunk.

to keep out the germs, and fungi. A covering of sheet iron or tin may keep out the rain, but it will not exclude the germs of decay; in fact, it may provide the very moist conditions that such germs need for their growth. Deep holes in trees should be treated by having all the decayed parts removed down to the clean wood, the surfaces painted or otherwise sterilized, and the hole filled with wax or cement.

Stems and roots are living, and they should not be wounded or mutilated unnecessarily. Horses should never be hitched to trees. Supervision should be exercised over persons who run telephone, telegraph, and electric light wires, to see that they do not mutilate trees. Electric light wires and trolley wires, when carelessly strung or improperly insulated, may kill trees (Fig. 67).

SugGestions. - Forms of stems. 43. Are the trunks of trees ever perfectly cylindrical? If not, what may cause the irregularities? Do trunks often grow more on one side than the other? 44. Slit a rapidly growing limb, in spring, with a knife blade, and watch the result during the season. 45. Examine the rroodpile, and observe the variations in thickness of the annual rings, and especially of the same ring at different places in the circumference. Cross-sections of

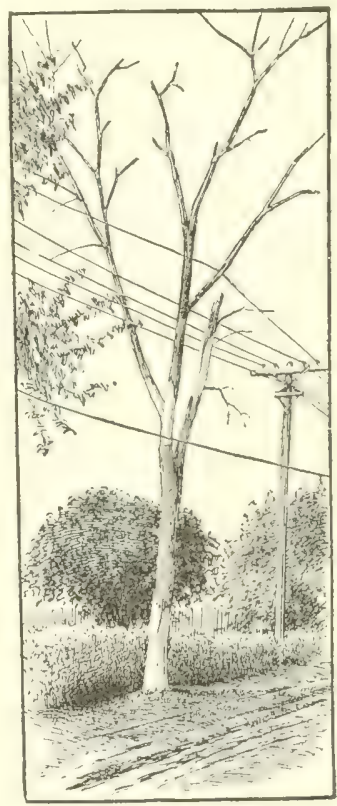

FIG.67.-ELM TREE KILLED BY A DIRECT CURRENT FROM AN ELECTRIC RAILROAD SYSTEM. 
horizontal branches are interesting in this connection. 46. Note the enlargement at the base of a branch, and determine whether this enlargement or bulge is larger on long, horizontal limbs than on upright ones. Why does this bulge (levelop? Does it serve as a brice to the limb, and is it developed as the result of constant strain? 47. Strength of stems. The pupil should olserve the fact that a stem has wonderful strength. Compare the proportionate height, diameter, and weight of a grass stem with those of the slenderest tower or steeple. Which has the greater strength? Which the greater height? Which will withstand the most wind? Note that the grass stem will regain its position even if its top is bent to the ground. Note how plants are weighted down after a heavy rain and how they recover themselves. 48. Split a cornstalk and observe how the joints are tied together and braced with fibres. Are there similar fibres in stems of pigweed, cotton, sunflower, hollyhock?

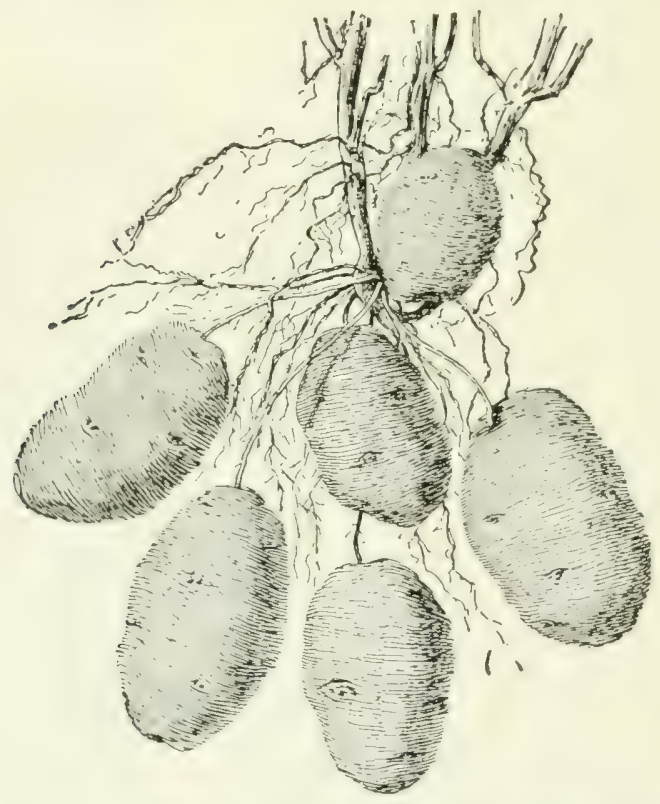

FIG. 68.- Potatn. What are roots, and what stems? Has the plant more than one kind of stem? more than two kinds? Explain. 


\section{CHAPTER X}

\section{THE STEM - ITS GENERAL STRUCTURE}

THERE are two main types of stem structure in flowering plants, the differences being based on the arrangement of bundles or strands of tissue. These types are endogenous and exogenous (page 20). It will require patient laboratory work to understand what these types and structures are.

Endogenous, or Monocotyledonous Stems. - Examples of endogenous stems are all the grasses, cane-brake, sugarcane, smilax or green-brier, palms, banana, canna, bamboo, lilies, yucca, asparagus, all the cereal grains. For our study, a cornstalk may be used as a type.

A piece of comstalk, either green or dead, should be in the hand of each pupil while studying this lesson. Fig. 69 will also

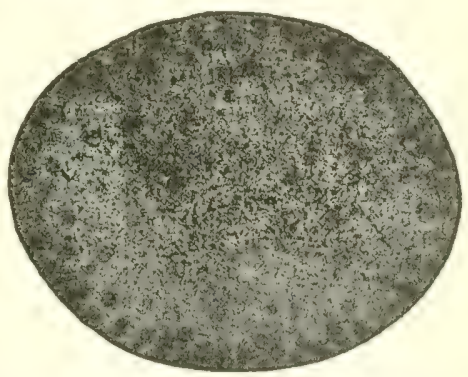

FIG. 69. - CROSS-SECTION OF CORNSTALK, showing the scattered fibrovascular bundles. Slightly enlarged. be of use. Is there a swelling at the nodes? Which part of the internode comes nearest to being perfectly round? There is a grooved channel running along one side of the internode: how is it placed with reference to the leaf? with reference to the groove in the internode below it? What do you find in each groove at its lower end? (In a dried stalk only traces of this are usually seen.) Does any bud on a cornstalk besides the one at 
the top ever develop? Where do suckers come from? Where does the ear grow?

Cut a cross-section of the stalk between the nodes (Firg. 69). Does it have a distinct bark? The interior consists of soft "pith" and tough woody parts. The wood is found in strands or fibres. Which is more abundant? Do the fihres have any definite arrangement? Which strands are largest? Smailest? The firm smooth rind (which cannot properly be called a bark) consists of small wood strands packed closely together. Grass stems are hollow cylinders; and the cornstalk, because of the lightness of its contents, is also practically a cylinder. Stems of this kind are admirably adapted for providing a strong support to leaves and fruit. This is in accordance with the well-known law that a hollow cylinder is much stronger than a solid

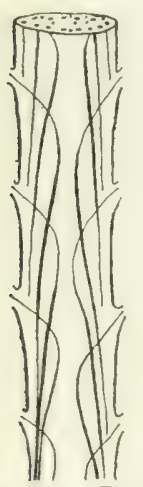

FIG. 70.- DIAGRAM TOSHOW THE COURSE OF

FIBRO-YASCULAR BUNDLES IN MONOCOTYLEDONS. cylinder of the same weight of material. Cut a thin slice of the inner soft part and hold it up to the light. Can you make out a number of tiny compartments or cells? These cells consist of a tissue called parencliyma, the tissue from which when young all the other tissues arise and differentiate. The numerous walls of these cells may serve to brace the outer wall of the cylinder; but their chief function in the young stalk is to give origin to other cells. When alive they are filled with cell sap and protoplasm.

Trace the suody strands through the nodes. Do they ascend vertically? Do they curve toward the rind at certain places? Compare their course with the strands shown in Fig. 70. The rooolly strands consist clicfly of tongh fibrous cells that give rigidity 
and strength to the plant, and of tomig tubular intermuted.

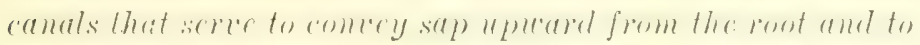

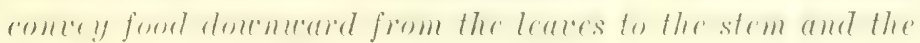
roots.

Monocotyledons, as shown by fossils, existed before dicotyledons appeared, and it is thought that the latter were developed from ancestors of the former. It will be interesting to trace the relationship in stem structure. It will first be necessary to learn something of the structure of the wood strand.

Wood Strand in Monocotyledons and Dicotyledons. Each wood strand (or fibro-vascular bundle) consists of two parts - the bast and the wood proper. The wood is on the side of the strand toward the centre of the stem and con-

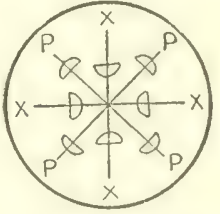

FIG.7I.-DIAGRAM OF W(M) SIKANIS OR IHI:RO-VASCL:LAR BUNI)LES IN A RooT, showing the wood $(x)$ and bast (p) separated. tains large tubular canals that take the watery sap upward from the roots. The bast is on the side toward the bark,

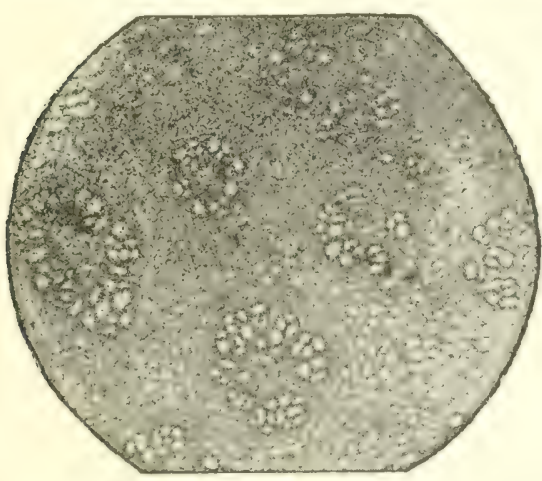

FIG. 72. - PART OF CROSS-SECTION OF ROOTSTOCK OF ASPARAGUS, showing a few fibrovascular bundles. An endogenous stem. and contains fine tubes through which diffuses the dense sap containing digested food from the leaves. In the root (Fig. 7I) the bast and the wood are separaté, so that there are two kinds of strands.

In monocotyledons, as already said, the strands (or bundles) are usually scattored in thi stom with no definite arrangement (Figs. 72, 73). In dicotyledons the strands, or bundles, are arranged in a 


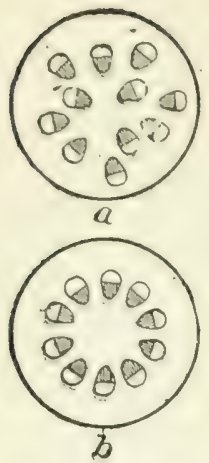

Fir. 73 - THE

SCATTERED

BUNDLES OR

STRANDS, in monocotyledons at $a$, and the bundles in a circle in dicotyledons at $b$.
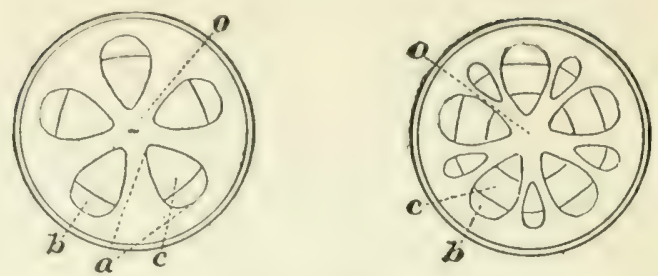

FIG. 74. - Dicotyledonous STEM OF ONE YEAR AT LEFT WITH FIVE BUNDLES, and a two-year stem at right.

$o$, the pith: $c$, the wood part: $b$, the bast part; $a$, one year's growth. ring. As the dicotyledonous seed germinates, five bundles are usually formed in its hypocotyl (Fig. 74); soon five more are interposed between them, and the multiplication continues, in tough plants, until the bundles touch (Fig. 74, right). The inner parts thus form a ring of wood and the outer parts form the inner bark or bast. A new ring of wood or bast is formed on stems of dicotyledons each year, and the age of a cut stem is easily determined.

When cross-sections of monocotyledonous and $\mathrm{di}$ cotyledonous bundles are examined under the microscope, it is readily seen

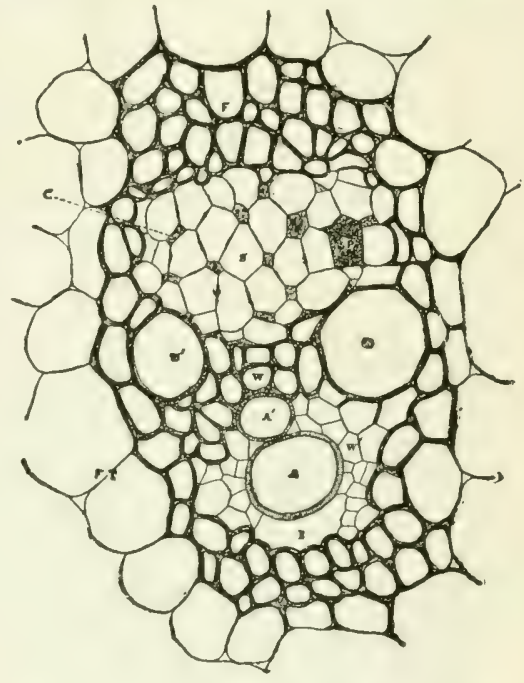

Fig. 75. - Fibro-vascular BUNDLE of INDIAN CORN, much magnified.

$A$, annular vessel ; $A^{\prime}$, annular or spiral vessel : $T T^{\prime}$, thick-walled vessels; $W$, tracheids or woody tissue ; $F$, sheath of fibrous tissue surrounding the bundle ; $F T$, fundamental tissue or pith; $S$, sieve tissue ; $P$, sieve plate: $C$, companion cell ; $I$, intercellular space, formed by tearing down of adjacent sells; $W^{\prime}$, wood parenchyma. 
why dicotyledonous bundles form rings of wood and monocotyledonous cannot (Figs. 75 and 76). The dicotyledonous bundle (Fig. 76) has, running across it, a layer of brickshaped cells called cambium, which cells are a specialized form of the parenchyma cells and retain the power of
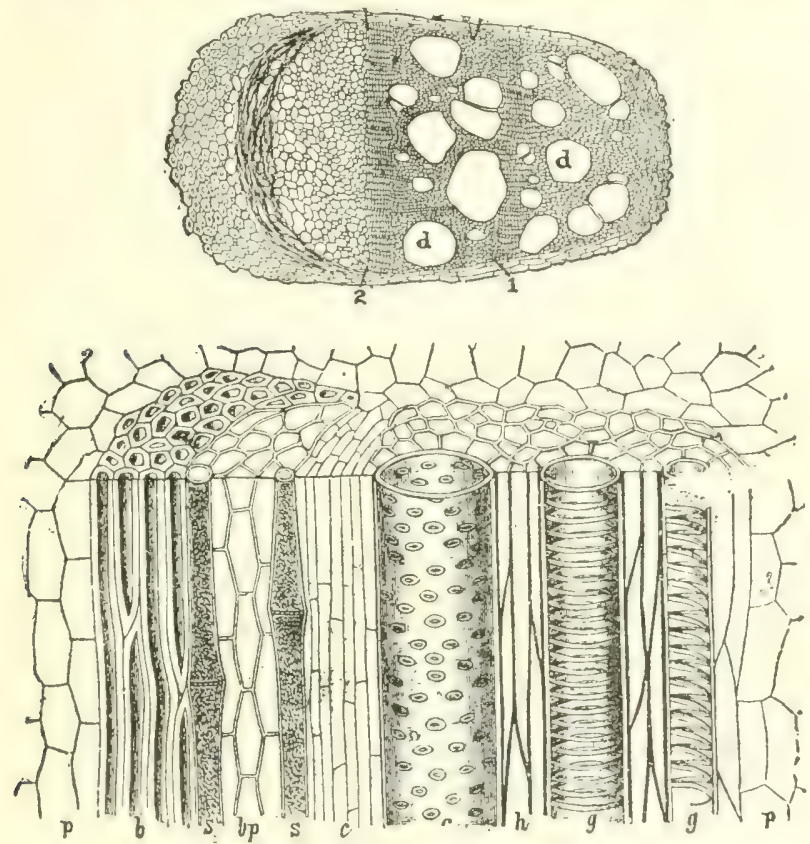

Fig. 76. - The Dicotylenonot's Bunde or Woon Strand. Upperfigure is of moonseed :

$c$, cambium ; $d$, ducts ; $I$, end of first year's growth ; 2 , end of second year's growth ; bast part at left and wood part at right. Lower figure (from Wettstein) is sunflower: $h$, woodcelis; $g$, vessels; $c$, cambium; $\not$, fundamental tissue or parenchyma; $b$, bast; $b p$, bast parenchyma; s, sieve-tubes.

growing and multiplying. The bundles containing cambium are called open bundles. There is no cambium in monocotyledonous bundles (Fig. 75) and the bundles are called closed bundles. Monocotyledonous stems soon ceasc to grow in dianctor. The stem of a palm tree is almost 
as large at the top as at the base. As dicotyledonous

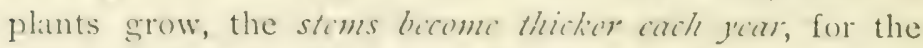
delicate atetive cambium layer forms new cells from early spring until midsummer or autumn, adding to the wood within and to the bark without. As the growth in spring is very rapid, the first wood-cells formed are much larger than the last wood-cells formed by the slow growth of the

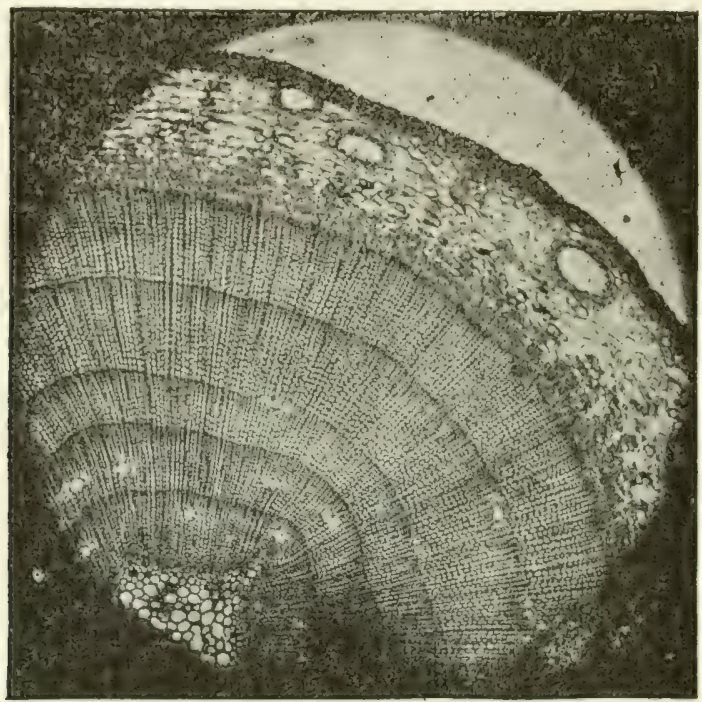

Fig. 77. - White Pine Stem, 5 years old. The outermost layer is bark.

late season, and the spring rood is less dense and of a Jighter "olour than tl:e summer wool; hence the time between two year:; growth is reacily made out (Figs. 77 and 78 ). Because of the rapid growth of the cambium in spring and its conserpuent soft walls and fluid contents, the bark of trees "peels" readily at that season.

Medullary Rays. - The first year's growth in dicotyledons forms a woody ring which almost incloses the pith, and this is left as a small cylinder which does not grow 
larger, even if the tree should live a century. It is not quite inclosed, however, for the narrow layers of soft cells separating the bundles remain between them (Fig. 78), forming radiating lines called medullary rays or pith rays.

\section{The Several Plant Cells and their} Functions, - In the wood there are some parenchyma cells that have thin walls still, but have lost
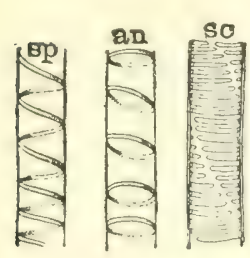
the power of division. They are now storage cells. There are also

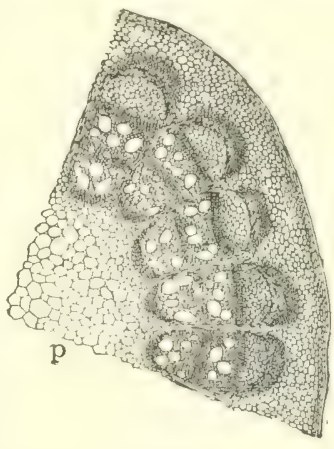

FIG. 78. - ARRANGEMENT OF TISSUES IN 'TWO-YEAROLD STEM OF MOONSEED. wood fibres which $s$, pith; $f$, parenchyma. The fibro. are thick-walled Fig. 79.-MArkin's and rigid (h, Fig. IN CELl Walts
of Wood Fibre sp, spiral; an, annular; or wood vessels (or tracheids) that are $s c$, scalariform. formed by the absorption of the end walls of upright rows of cells; the canals pass from the roots to the twigs and even to ribs of the leaves and serve to transport the root water. They are recognized (Fig. 79) by the peculiar thickening of the wall on the inner surface of the tubes, occurring in the form of spirals. Sometimes the whole wall is thickened except in spots called pits ( $g$, Fig. 76). These thin spots (Fig. 80) allow the sap to pass to other cells or to neighbouring vessels.

The cambium, as we have seen, consists of cells whose function is growth. These

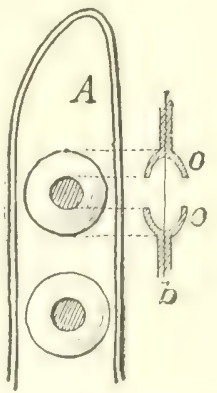

Fir, 80.-PITS IN THE CELL WALL.

Longitudinal section of wall at $b$, showing put burders at 0,0 . 
cells are thin-walled and filled with protoplasm. During the growing season they are continually adding to the

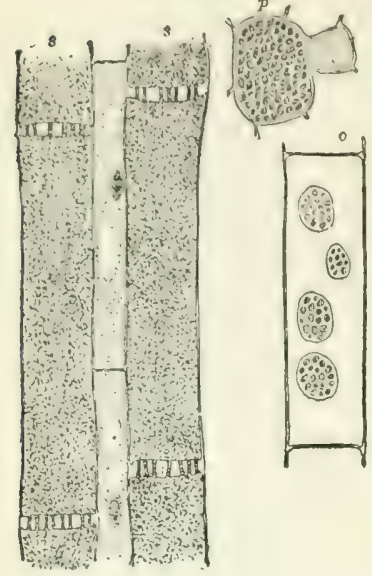

FIG. 81.-SIEVE-TUBES, $s, s$;

b shows a top view of a sieve-plate, with a companion cell. $c$, at the side; o shows sieve-plates in the side of the cell. In $s, s$ the protoplasm is shrunken from the walls by reagents. wood within and the bark without; hence the layer moves outward as it deposits the new woody layer within.

The bark consists of inner or fibrous bark or new bast (these fibres in flax become linen), the green or middle bark which func. tions somewhat as the leaves, and the corky or outer bark. The common word "bark" is seen, therefore, not to represent a homogeneous or simple structure, but rather a collection of several kinds of tissue, all separating from the wood beneath by means of cambium. The new bast contains (I) the sicve-tubes (Fig. 8I) which transport the sap containing organic substances, as sugar and proteids, from the leaves to the parts needing it ( $s$, Fig. 76). These tubes have been formed like the wood vessels, but they have sieve-plates to allow the dense organic-laden sap to pass with sufficient readiness for purposes of rapid distribution. (2) There are also thick-walled bast fibres (Fig. 82) in the bast that serve for support. ( 3 ) There is also some parenchyma in the new bast; it is now in part a stcraga tissue. Some-

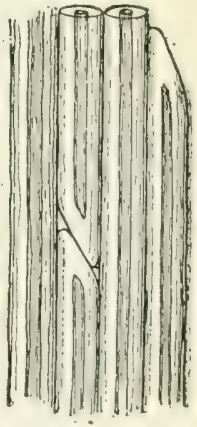

FIG. 82,-THICKWALLED BAST CELLS. 
times the walls of parenchyma cells in the cortex thicken at the corners and form brace colls (Fig. $8_{3}$ ) (collenchyma) for support; sometimes the whole wall is thickened, forming grit cells or stone cells (Fig.

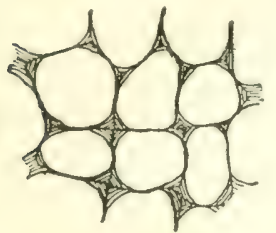

FIG. 83. - COLLENCHY MA IN WILD JEWELWEED OR TOUCH-ME-NOT (IMPATIENS).

84; examples in tough parts of pear, or in stone of fruits). Some parts serve for secretions (milk, rosin, etc.) and are called latex tubes.

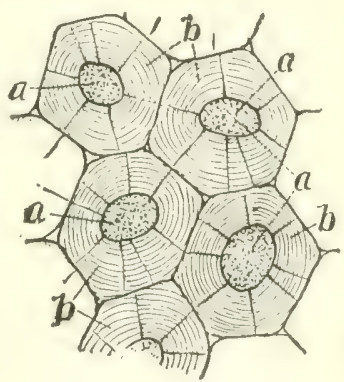

FIG. 84.-GRIT CEILS.

The outer bark of old shoots consists of corky cells that protect from mechanical injury, and that contain a fatty substance (suberin) impermeable to water and of service to kecp in moisture. There is sometimes a cork cambium (or phellogen) in the bark that serves to extend the bark and keep it from splitting, thus increasing its power to protect.

Transport of the "Sap." - We shall soon learn that the common word "sap" does not represent a single or simple substance. IVe may roughly distinguish two kinds of more or less fluid contents: (I) the root water, sometimes called mineral sap, that is taken in by the root, containing its freight of such inorganic substances as potassium, calcium, iron, and the rest; this root water rises, we have found, in the wood resscls, - that is, in the young or "sapivood" ( $p$. 95); (2) the claborated or organized matcrials passing back and forth, especially from the leaves, to build up tissues in all parts of the plant, some of it going duwn to the roots and root-hairs; this organic material is transported, as we have learned, in the sicate-tubes of the inn r bast, - that is, in the "inner bark." Removing the hark from a trunk in 
a girclle will not stop the upward rise of the root water so long as the wood remains alive; but it will stop the passage of the elaborated or food-stored materials to parts below and thus starve those parts; and if the girdle does not heal over by the deposit of new bark, the tree will in time starec to diath. It will now be seen that the common practice of placing wires or hoops about trees to hold them in position or to prevent branches from falling is irrational, because such wires interpose barriers over which

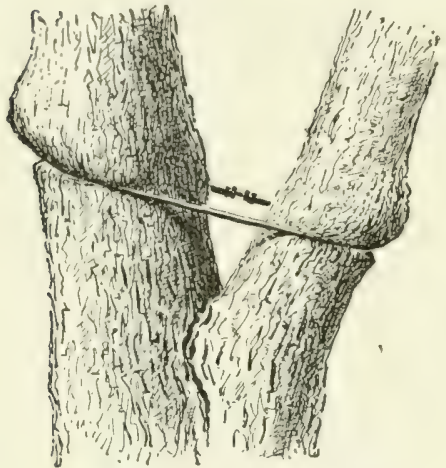

Fig. 85.-THE WRONG WAY TO

ERACE A TREE. (See Fig. IIE). the fluids cannot pass; in time, as the trunk increases in diameter, the wire girdles the tree. It is much better to bolt the parts together by rods extending through the branches (Fig. 85). These bolt's should fit very tight in their holes. Why?

Wood. - The main stem or trunk, and sometimes the larger branches, are the sources of lumber and tim-

ber. Different kinds of wood have value for their special qualities. The business of raising wood, for all purposes, is known as forestry. The forest is to be considered as a crop, and the crop must be harvested, as much as corn or rice is harvested. Man is often able to grow a more productive forest than nature does.

Resistance to decay gives value to wood used for shingles (cypress, heart of jellow pinc) and for fence posts (mulberry, cedar, post oak, bois d'are, mesquite).

Hardness and strength are qualities of great value in building. Live oak is used in ships. Red oak, rock maple, 
and yellowe pine are used for floors. The best flooring is sa:vn with the straight edges of the annual rings upward; tangential sawn flooring may splinter. Chestmut is common in some parts of the country, being used for ceiling and inexpensive finishing and furniture. Locust and bois d'are (osage orange) are used for hubs of wheels; bois d'arc makes a remarkably clurable pavement for streets. Ebony is a tropical wood used for flutes, black piano keys, and fancy articles. As/h is straight and elastic; it is used for handles for light implements. Hickury is very strong as well as elastic, and is superior to ash for handles, spokes, and other uses where strength is wanted. Hickory is never sawn into lumber, but is split or turned. The "second growth," which sprouts from stumps, is most useful, as it splits readily. Fast-growing hickory in rich land is most valuable. The supply of useful hickory is being rapidly exhausted.

Softness is often importent. Ithile fine and secect grtm because of their softness and lightness are useful in boxmaking. "Georgice" or southern fine is harder and stronger than white pine; it is much used for floors, ceilingrs, and some kinds of "ahinet work. White pine is used for windowsash, doors, and moulding, and cheaper grades are used for flooring. Himlock is the prevailing lumber in the east for the framework and clapboarding of buildings. Redwood and Douglas spmuce are common building materials on the Pacific coast. Crpriss is soft and resists decay and is superior to white pine for sash, cloors, and posts on the outside of houses. Cedar is readily carved and has a unique use in the making of chests for " lothes. ai its odour repels moths and other insects. Willow is useful for baskets and light furniture. Parsatood or lindin is used for light ceiling and sometimes for cheap floors. Whitewoot 
(incorrectly called poplar) is employed for wagon bodies and often for house finishing. It often resembles curly maple.

Beauty of grain and polish gives wood value for furniture; pianos, and the like. Mahogany and white oak are most beautiful, although red oak is also used. Oak logs which are first quartered and then sawn radially expose the beautiful silver grain (medullary rays). Fig. 86 shows one

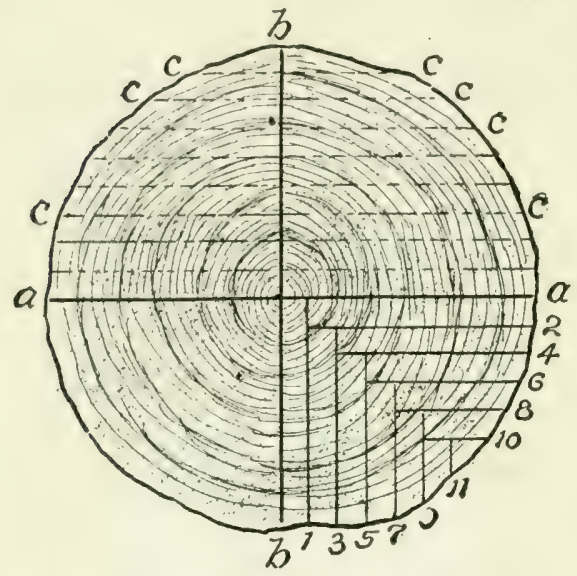

FIG, 86. - THE MAKING OF ORDINARY BOARDS, aNd ONe Way of Making "Quartered" BOAKDS. mode of quartering. The $\log$ is quartered on the lines $a, a, b, b$; then succeeding boards are cut from each quarter at $\mathrm{I}$, 2,3 , etc. The nearer the heart the better the "grain".: why? Ordinary boards are sawn tangentially, as $c, c$. Curly pine, curly walnut, and bird's-eye maple are woods that owe their beauty of grain to wavy lines or buried knots. A mere stump of curly walnut is worth several hundred dollars. Such wood is sliced very thin for veneering and glued over other woods in making pianos and furniture. If the cause of wavy grain could be found out and such wood grown at will, the discovery would be very useful. Maple is much used for furniture. Birch may be coloured so as very closely to represent mahogany, and it is useful for desks.

Special Products cf Trees.-Cor?. from the bark of the cork oak in Spain, latex from the rubber, and sap from the 
sugar-maple trees, turpentine from pine, tannin from oak bark, Peruvian bark from cinchona, are all useful products.

SugGestions. - Parts of a root and stem through zethich liquids rise. 49. Pull up a small plant with abundant leaves, cut off the root so as to leave two inches or more on the plant (or cut a leafy shoot of squash or other strong-growing coarse plant), and stand it in a bottle with a little water at the bottom which has been coloured with red ink (eosine). After three hours examine the root; make cross sections at several places. Has the water coloured the axis cylinder? The cortex? What is your conclusion? Stand some cut flowers or a leafy plant with cut stem in the same solution and examine as before: conclusion? 50. Girdle a twig of a rapidly growing bush (as willow) in early spring when growth begins (a) by very carefully removing only the bark, and (b) by cutting away also the sapwood. Under which condition do the leaves wilt? Why? 51. Stand twigs of willow in water; after roots have formed under the water, girdle the twig (in the two ways) above the roots. What happens to the roots, and why? 52. Observe the swellings on trees that have been girdled or very badly injured by wires or otherwise: where are these swellings, and why? 53. Kinds of wood. Let each pupil determine the kind of wood in the desk, the floor, the door and window casings, the doors themselves, the sash, the shingles, the fence, and in the small implements and furniture in the room; also what is the cleapest and the most expensive lumber in the community. 54. How many kinds of wood does the pupil know, and what are their chief uses?

Note to TFacher. - The work in this chapter is intended to be mainly descriptive, for the purpose of giving the pupil a rational conception of the main vital processes associated with the stem, in such a way that he may translate it into his daily thought. It is not intended to give advice for the use of the compound microscope. If the pupil is led to make a careful study of the text, drawings, and photographs on the preceding and the following pages, he will obtain some of the benefit of studying microscope sections without being forced to spend time in mastering microscope technique. If the school is equipped with compound microscopes, a teacher is probably chosen who has the necessary skill to manipulate them and the knowledge of anatomy and physiology that goes naturally with such work; and it would be useless to give instruction in such work in a text of this kind. The writer is of the opinion that the introduction of the compound microscope into first courses in botany has been productive of harm. Good and vital teaching demands first that the pupil have a normal, 
direct, and nitural relation to his subject, as he commonly meets it, that the obvious amel signiticant features of the plant world be explained to him and be mate a means of training him. The begimning pupil camnot be expected to know the fundamental physiological processes, nor is it necessary that these processes should be known in order to have a point of view and trained intelligence on the things that one customarily sees. Many a pupil has hal a so-called laboratory course in botany without having arrived at any real conception of what plants mean, or without having had his mind opened to any real sympathetic touch with his environment. Even if one's knowledge be not deep or extensive, it may still be accurate as far as it goes, and his outlook on the subject may be rational.

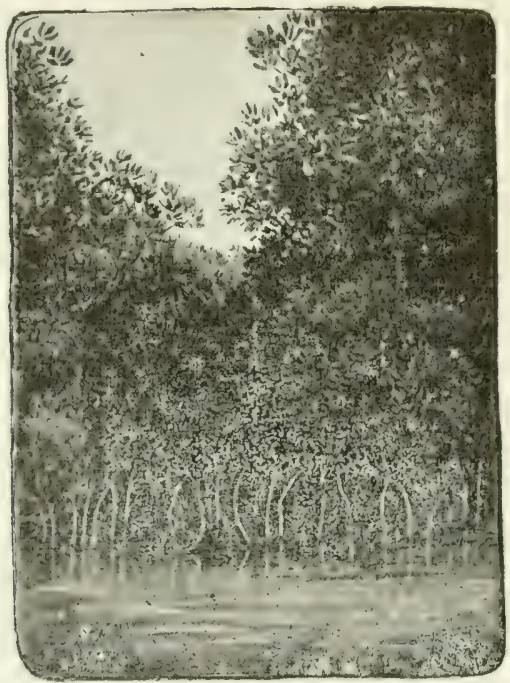

Fig. 87. - THF MANY-STEMMED THickets of MANGROVE OF SOUTHERNMOST SEACOASTS, many of the trunks being formed of aërial roots. 


\section{CHAPTER XI}

\section{LEAVES - FORM AND POSITION}

Leaves may be studied from four points of view, - with reference to (1) their livuls and shapes; (2) their fosition, or arrangcment on the plant; (3) their anatomy, or structure;

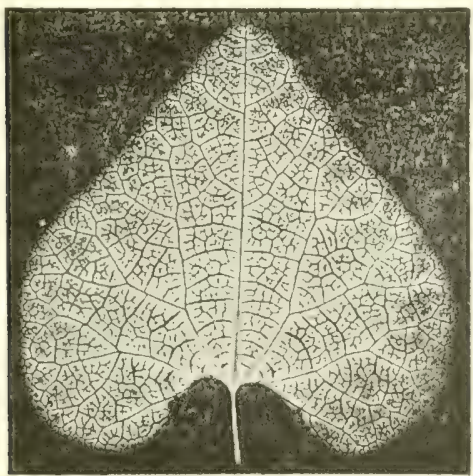

Fig. 88. - A Simple Netted-Veined LEAF.

(4) their function, or the work they perform. This chapter is concerned

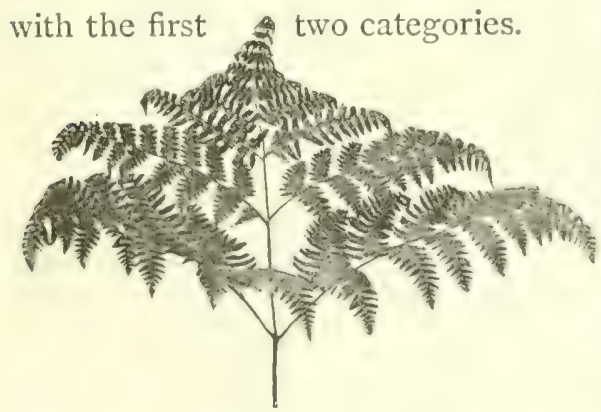

Fig. 90.-Compound or Branched Leaf OF BRAKE (a common fern).

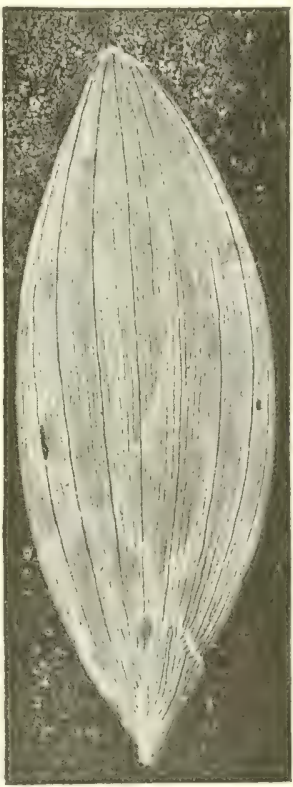

FIG. 89. - A SIMPLE PARALLEL-VEINED LEAF,

Kinds. - Leaves are simple or unbranched (Figs. 88, 89), and compound or branched (Fig. 90). 
The method of compounding or branching follows the mode of veining. The veining, or venation, is of two gen-

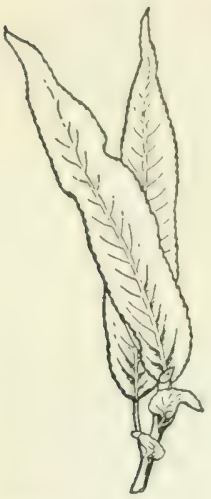

FIG, 91. - CoM-

PLETE LEATES OF

WILLOW. eral kinds. In some plants the main veins diverge, and there is a conspicuous network of smaller veins; such leaves are netted-veined. They are characteristic of the dicotyledons. In other plants the main veins are parallel, or nearly so, and there is no conspicuous network; these are parallel-veined leaves (Figs. 89, 102). These leaves are the rule in monocotyledonous plants. The venation of nettedveined leaves is pinnate or feather-like when the veins arise from the side of a continuous midrib (Fig. 91); palmate or digitate (hand-like) when the veins arise from the apex of the petiole (Figs. 88, 92). If leaves were divided between the main veins, the former would be pinnately and the latter digitately compound.

It is customary to speak of a leaf as compound only when the parts or branches are completely separate blades,

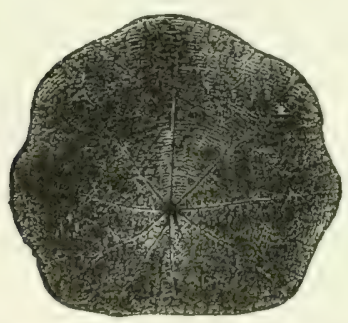

Fig. 92,- Digitate-Veined PELtate Leaf of Nasturtium.

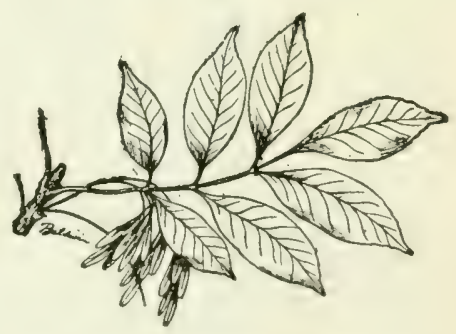

Fig. 93.- Pinnately Compound LEAF OF ASH.

as when the division extends to the midrib (Figs. 90, 93, 94, 95). The parts or branches are known as leaflets. 
Sometimes the leaflets themselves are compound, and the whole leaf is then said to be bi-compound or twice-com-

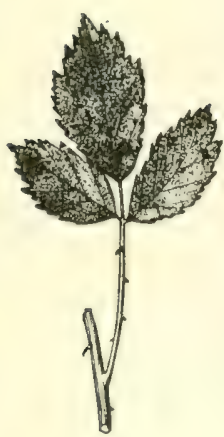

FIG. 94. - DIGITATELY COMPOUND LEAF OF RASPBERRY.

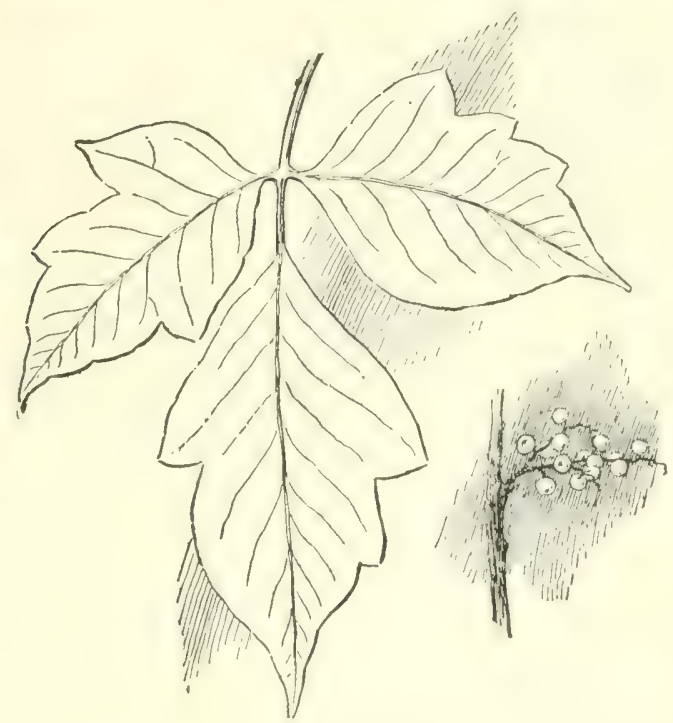

FiG. 95. - POISON Iry. LEAF AND FrUIT.

pound (Fig. 90). Some leaves are three-compound, fourcompound, or five-compound. Decompound is a general term to express any degree of compounding beyond twice-compound.

Leaves that are not divided as far as to the midrib are said to be :

lobed, if the openings or sinuses are not more than half the depth of the blade (Fig. 96);

cleft, if the sinuses are deeper than the middle;

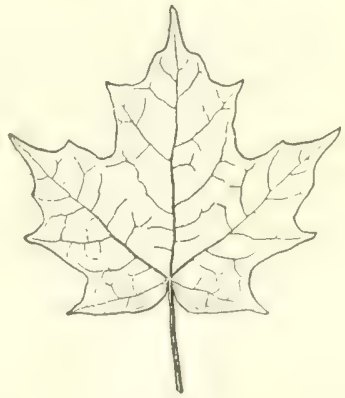

FIG. 96. - LOBED LEAF OF SUGAR MAPLE。 


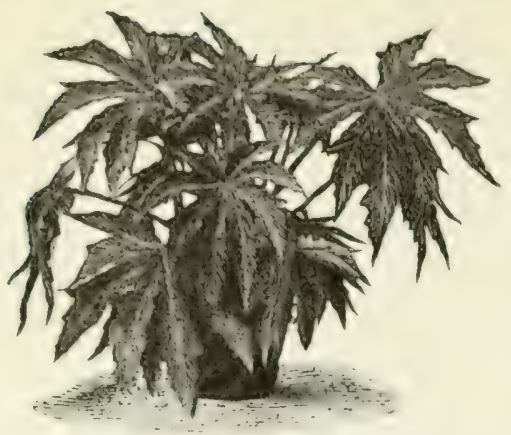

Fig. 97.-Digitately Parted Leaves OF BEGONIA.

parted, if the sinuses reach two thirds or more to the midrib (Fig. 97);

divided, if the sinuses reach nearly or quite to the midrib.

The parts are called lobes, divisions, or segments, rather than leaflets. The leaf may be pinnately or digitately lobed, parted, cleft, or divided. A pimnately parted or cleft leaf is sometimes said to be pinnatifid.

\section{Leaves may have} one or all of three parts - blade, or expanded part; petiole, or stalk ; stipules, or appendages at the base of the petiole. A leaf that has all three of these parts is said to be complete (Figs. 9I, 106). The stipules are often green and leaflike and perform the function Fig. 93.-Oblongof foliage as in the
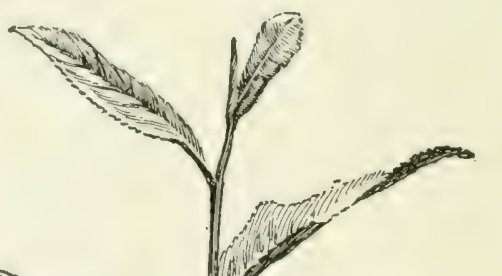
pea and the Japanese quince (the latter common in yards).

Leaves and leaflets that have no stalks are said to be sessile (Figs. 98, I03), i.c. sitting. Find several examples. 
The same is said of flowers and fruits. The blade of a sessile leaf may partly or wholly surround the stem, when it is said to be clasping. Examples: aster (Fig. 99), corn. In some cases the leaf runs down the stem, forming a wing; such leaves are said to be decurrent (Fig. IOO). When opposite sessile leaves are joined by their bases, they are said to be connate (Fig. IOI).

Leaflets may have one or all of these

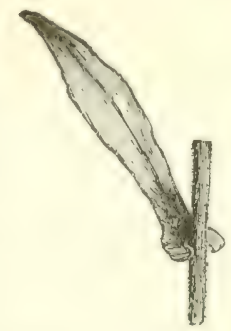

FIG. 99. - CLASPINI I IINA OF A WILD ASTER.

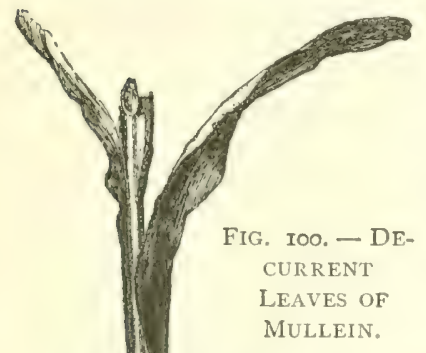

three parts, but the stalks of leaflets are called petiolules and the stipules of leaflets are called stipels. The leaf of the garden bean has leaflets, petiolules, and stipels.

The blade is usually attached to the petiole by its lower edge. In pinnate-veined leaves, the petiole seems to continue through the leaf as a midrib (Fig. 9I). In some plants, however, the petiole joins the blade inside or beyond the margin (Fig. 92). Such leaves are said to be peltate or shield-shaped. This mode of attachment is particularly common in floating leaves (e.g. the water lilies). Peltate leaves are usually digitate-veined.

How to Tell a Leaf. - It is often difficult to distinguishcompound leaves from leafy branches, and leaflets

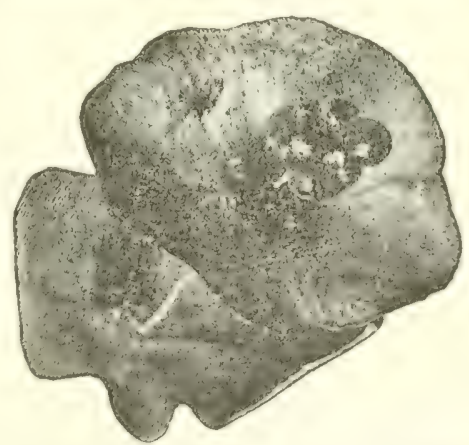

EIg. IOI. - Two PAIRS OF CONNATE LEAVES OF HUNEXSUCKI.1. 
from leaves. As a rule leaves can be distinguished by the following tests: (1) Leates are timforaly structures, sooner or later falling. (2) Usually buts are borne in their

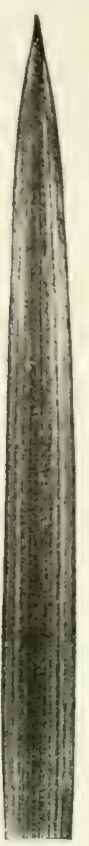

FIG. I02, -

LINEARACUMINATE

LEAF OF

GRASS. a.rils. (3) Leares are usually bornc at joints or nouts. (4) They arise on wood of the currint jear's growoth. (5) 'They have a more or less difinite arangement. When leaves fall, the twig that bore them remains; when leaflets fall, the main petiole or stalk that bore them also falls.

Shapes. - Leares and leaflets are infinitely variable in shape. Names have been given to some of the more definite or regular shapes. These names are a part of the language of botany. The names represent ideal or typical shapes; there are no two leaves alike and very few that perfectly conform to the definitions. The shapes are likened to those of familiar objects or of geometrical figures. Some of the commoner shapes are as follows (name original examples in each class):

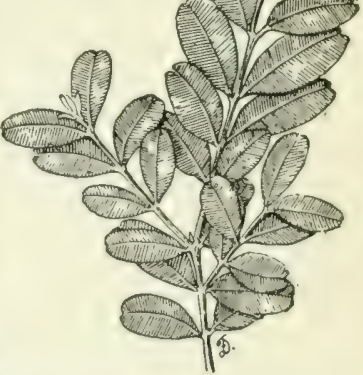

FIG. IO3. - SHORT-OBLONG LEAVES OF BOX.

Linear, several times longer than broad, with the sides nearly or quite parallel. Spruces and most grasses are examples (Fig. I02). In linear leaves, the main veins are usually parallel to the midrib.

Oblong, twice or thrice as long as broad, with the sides parallel for most of their length. Fig. IO3 shows the short-oblong leaves of the box, a plant that is used for permanent edgings in gardens. 
Elliptic differs from the oblong in having the sides gradually tapering to either end from the middle. The

European beech (Fig. IO4) has elliptic leaves. (This tree is often planted in this country.)

Lanceolate, four to six times longer than broad, widest below the middle, and tapering to either end. Some of the narrow-leaved willows are examples. Most of the willows and the peach have oblong-lanceolate leaves.

Spatulate, a narrow leaf that is broadest toward the apex. The top is usually

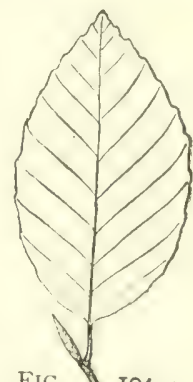

FIG. IO4. ELLIPTIC LEAF (IF PLRPLE. BEECH.

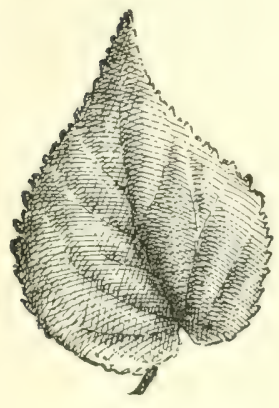

FIG. I05. - OVATE SER R ATE LEAF OF HIBISCUS.

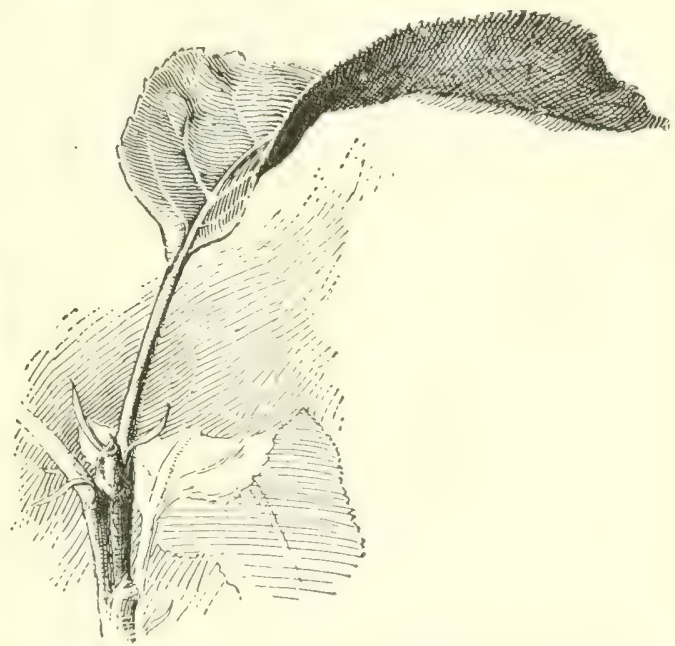

Fig. 106.-Leaf of APPle, showing blade, petiole, and small narrow stipules.

Ovate, shaped somewhat like the longitudinal section of an egg: about twice as long as broad, tapering from near the base to the apex. This is one of the commonest leaf forms (Figs. 105, 106). 
Obovate, ovate inverted, - the wide part towards the apex. Leaves of mullein and leaflets of horse-chestnut and false indigo are obovate. This form is commonest in leaflets of digitate leaves: why?

Reniform, kidney-shaped. This form is sometimes seen in wild plants, particularly in root-leaves. Leaves of wild ginger are nearly reniform.

Orbicular, circular in general outline. Very few leaves are perfectly circular, but there are many that are nearer circular than of any other shape. (Fig. 107).

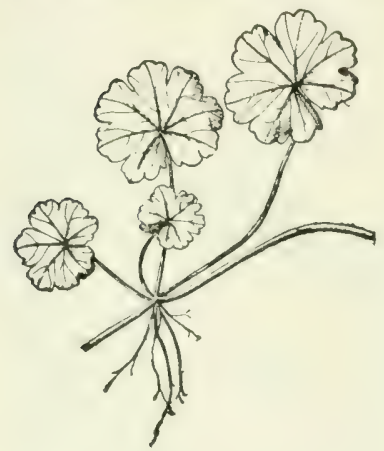

FIG. I07. - ORBICULAR LOBED LEAVES.

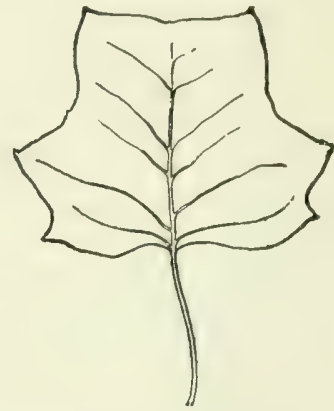

Fig. IOS, - TRUNCATE LEAF OF TUliP TREE.

The shape of many leaves is described in combinations of these terms : as ovate-lanceolate, lanceolate-oblong.

The shape of the base and the apex of the leaf or leaflet is often characteristic. The base may be rounded (Fig. IO4), tapering (Fig. 93), cordate or heart-shaped (Fig. 105), truncate or squared as if cut off. The apex may be blunt or obtuse, acute or sharp, acuminate or long-pointed, truncate (Fig. 108). Name examples.

The shape of the margin is also characteristic of each kind of leaf. The margin is entire when it is not indented or cut in any way (Figs. 99, 103). When not 
entire, it may be undulate or wavy (Fig. 92), serrate or saw-toothed (Fig. I05), dentate or more coarsely notched (Fig. 95), crenate or round-toothed, lobed, and the like. Give examples.

Leaves on the same plant often diftere greatly in form. Observe the different shapes of leaves on the young rrowths of mulberries (Fig. 2) and wild grapes; also on vigorous squash and pumpkin vines. In some cases there may be simple and compound leaves on the same plant. This is marked in the so-called Boston ivy or ampelopsis (Fig. IO9), a vine that is used to cover brick and stone buildings. Different degrees of cumpounding, even in the same leaf, may often be found in honey locust. Remarkatule diiferences in forms are

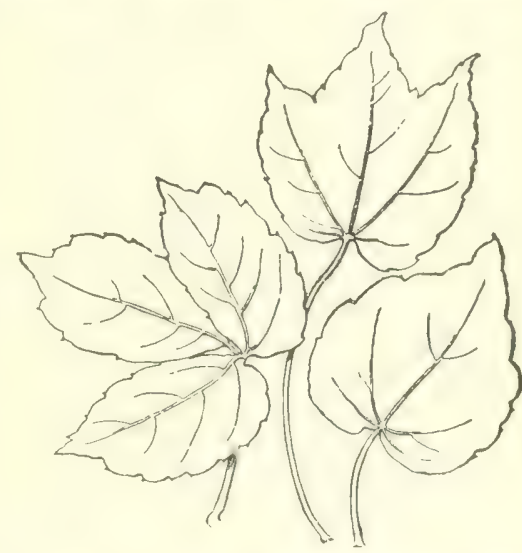

FIG, IO9. - DIFFERENT FORMS OF I.EAVES FROM ONE PLANT OF AMPELOPSIS. seen hy romparing seed-leaves with matupe leaves of any plant (Fig. 30).

The Leaf and its Environment. - The form and shape of the leaf often have direct relation to the place in which the leaf growes. Fluating liares are uswally cxpanded and flat, and the petiole varies in length with the depth of the water. Submerged leares are usually lincar or theadlific, or are cut into very narrow divisions: thereby more surface is exposed, and possibly the leaves are less in; uied by moving water. Compare the sizes of the leaves on the ends of branches with those at the base of the 
branches or in the interior of the tree top. In dense foliage masses, the petioles of the lowermost or undermost leaves tind to clongati - to push the leaf to the light.

On the approach of winter the leaf usually ceases to work, and dies. It may drop, when it is said to be deciduous; or it may remain on the plant, when it is said to be persistent. If persistent leaves remain green during the winter, the plant is said to be evergreen. Give examples in each class. Most leaves fall by breaking off at the lower end of the petiole with a distinct joint or articulation. There are many leaves, however, that wither and hang on the plant until torn off by the wind; of such are the leaves of grasses, sedges, lilies, orchids, and other plants of the monocotyledons. Most leaves of this character are parallel-veined.

Lear'es also dic and fall from lack of light. Observe the yellow and weak leaves in a dense tree top or in any thicket. Why do the lower leaves die on house plants? Note the carpet of needles under the pines. All evergreens shed their leaves after a time. Counting back from the tip of a pine or spruce shoot, determine how many years the leaves persist. In some spruces a few leaves may be found on branches ten or more years old.

Arrangement of Leaves. - Most leaves have a regular position or arrangcment on the stem. This position or direction is detcrmincd largely by cxposure to sunlight. In temperate climates they usually hang in such a way that they receive the greatest amount of light. One leaf shades another to the least possible degree. If the plant were placed in a new position with reference to light, the leaves would make an effort to turn their blades.

When leaves are opposite the pairs usually altcrnate. That is, if one pair stands north and south, the next pair 
stands east and west. See the box-elder shoot, on the left in Fig. IIO. One pair docs not shade the pair bencath. The leaves are in four vertical ranks.

There are several kinds of alternate arrangcment. In the elm shoot, in Fig. I IO, the third bud is vertically above the first. This is true no matter which bud is taken as the starting point. Draw a thread around the stem until the two buds are joined. Set a pin at each bud. Observe that two buds are passed (not counting the last) and that the thread makes one circuit of the stem. Representing the number of buds by a denominator, and the number of circuits by a numerator, we have the fraction $\frac{1}{2}$, which expresses

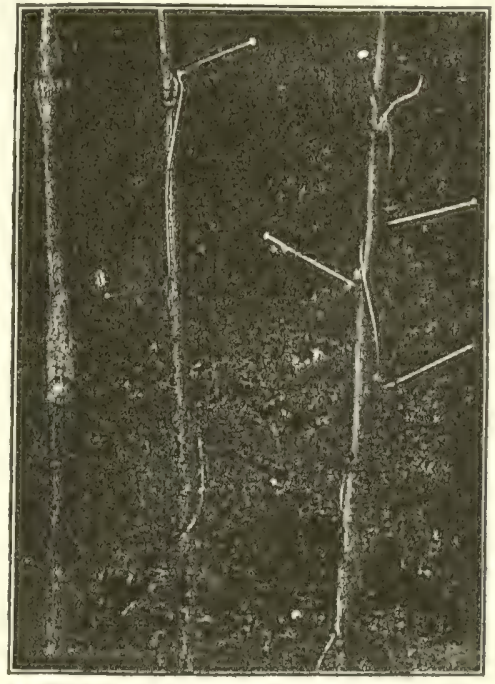

Fig. ilo. - Phy i.totaxy of Box Elder, EI.M, APPLE.

the part of the circle that lics betwcen any two buds. That is, the buds are one half of 360 degrees apart, or I80 degrees. Looking endwise at the stem, the leaves are seen to be 2-ranked. Note that in the apple shoot (Fig. IIO, right) the thread makes two circuits and five buds are passed: two fifths repiescnts the divergence between the buds. The leaves are 5-ranked.

Eacry plant has its own arrangoment of laves. For opposite leaves, see maple, box elder, ash, lilac, honeysuckle, mint, fuchsia. For 2-ranked arrangement, see all grasses, Indian corn, basswood, elm. For 3-ranked 
arrangement, see all sedges. For 5-ranked (which is one of the commonest), see apple, cherry, pear, peach, plum, poplar, willow. For S-ranked, see holly, osage orange, some willows. More complicated arrangements occur in bulbs, house leeks, and other eomilensed plants. The buds or "eyes" on a potato tuber, which is an underground stem

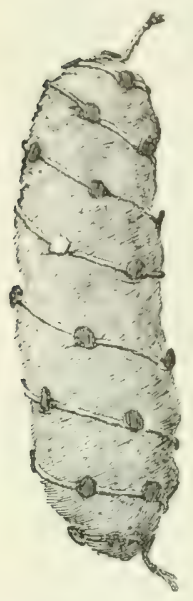

FIG. rit. -

PHYLIOTAXY OF THF PGTATO TIEER Work it out on a fresh long tuber. (why?), show a spiral arrangement ( Iigg. I I I ). The arrangement of leaves on the stem is lnown as phyllotaxy (literally, "leaf arrangement"). Make out the phyllotaxy on six different plants nearest the schoolhouse door.

In some plants, several leaves occur at one level, being arranged in a circle around the stem. Such leaves are said to be verticillate, or whorled. Leaves arranged in this way are usually narrow: why?

Although a definite arrangement of leaves is the rule in most plants, it is subject to modification. On shoots that receive the light only from one side or that grow in difficult positions, the arrangement may not be definite. Examine shoots that grow on the under side of dense tree tops or in other partially lighted positions.

Suggestions. - 55. The pupil should match leaves to determine whether any two are alike. Why? Compare leaves from the same plant in size, shape, colour, form of margin, length of petiole, venation, texture (as to thickness or thinness), stage of maturity, smoothness or hairiness. 56. Let the pupil take an average leaf from each of the first ten different kinds of plants that he meets and compare them as to the above points (in Exercise 55 ), and also name the shapes. Determine how the various leaves resemble and differ. 57. Describe the stipules of rose, apple, fig, willow, violet, pea, or others. 58. In what part of the world are parallel-veined leaves the more common? 59. Do 
you know of parallel-veined leaves that have lobed or dentate margins? 60. What becomes of dead leaves? 61. Why is there no grass or other undergrowth under pine and spruce trees? 62. Name several leaves that are useful for decorations. Why are they useful? 63. What trees in your vicinity are most esteemed as shade trees? What is the character of their foliage? 64. Why are the internodes so long in water-sprouts and suckers? 65. How do foliage characters in corn or sorghum differ when the plants are grown in rows or broadcast? Why? 66. Why may removal of half the plants increase the yield of cotton or sugarbeets or lettuce? 67. How do leaves curl when they wither ? Do different leaves behave differently in this respect? 68. What kinds of leaves do you know to be eaten by insects? By cattle? By horses? What kinds are used for human food? 69. How woukd you describe the shape of leaf of peach? apple? elm? hackberry? maple? sweet-gum? corn? wheat? cotton? hickory? cowpea? strawberry? chrysanthemum? rose? carnation? 70. Are any of the foregoing leaves compound? How do you describe the shape of a compound leaf? 71. How many sizes of leaves do you find on the bush or tree nearest the schoolroom door? 72. How many colours or shades? 73. How many lengths of petioles?

74. Bring in all the shapes of leaves that you can find.

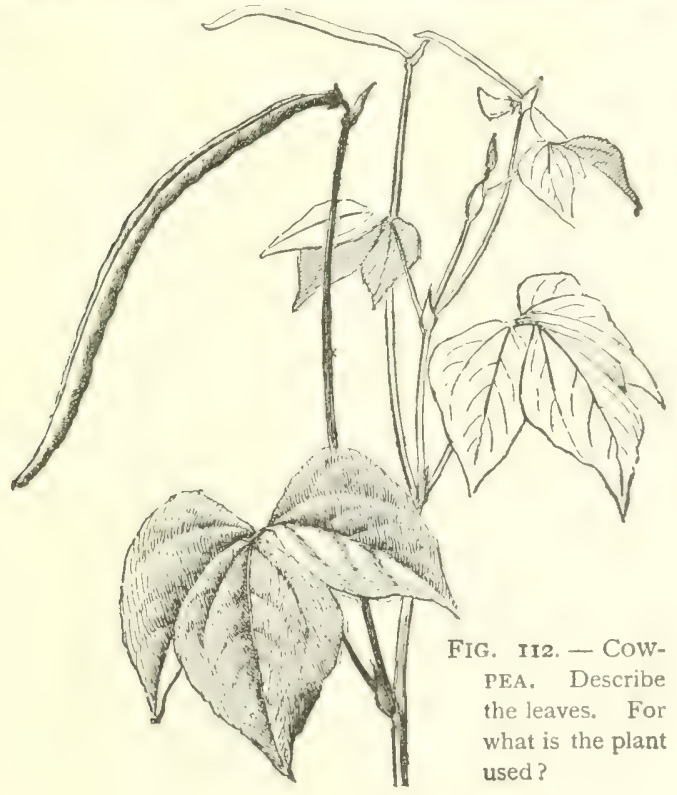




\section{CHAPTER XII}

\section{LEAVES - STRUCTURE OR ANATOMY}

Besides the framework, or system of veins found in blades of all leaves, there is a soft cellular tissue called mesophyll, or leaf parenchyma, and an epidermis or skin that covers the entire outside part.

Mesophyll. - The mesophyll is not all alike or homogencous. The upper layer is composed of elongated cells placed perpendicular to the surface of the leaf. These are called palisade cells. These cells are usually filled

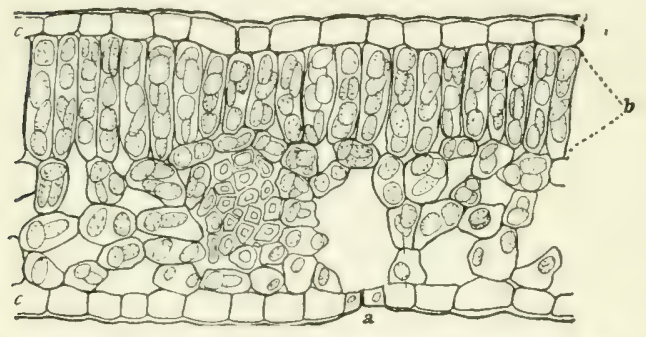

FIG. II3. - SECTION OF A LEAF, showing the air spaces.

Breathing-pore or stoma at $a$. The palisade cells which chiefly contain the chlorophyll are at $b$. Epidermal cells at $c$. with green bodies called chlorophyll grains. The grain contains a great number of chlorophyll drops imbedded in the protoplasm. Below the palisade cells is the spongy parenchyma, composed of cells more or less sphercal in shape, irregularly arranged, and provided with many intercellular air cavities (Fig. I I3). In leaves of some plants exposed to strong light there may be more than one layer of palisade cells, as in the India-rubber plant and the oleander. Iry when grown in hright light will develop two such layers of cells, but in shaded places it may be 
found with only one. Such plants as iris and compass plant, which have both surfaces of the leaf equaliy exposed to sunlight, usually have a palisade layer beneath each epidermis.

Epidermis. - The outer or epidermal cells of leaves do not bear chlorophyll, but are usually so transparent that the green mesophyll can be seen through them. They often become very thick-walled, and are in most plants devoid of all protoplasm except a thin layer lining the walls, the cavities being filled with cell sap. This sap is sometimes coloured, as in the under epidermis of begonia leaves. It is not common to find more than one layer of epidermal cells forming each surface of a leaf. The epidermis scries to retain moisture in the leaf and as a general protcctive coucring. In desert plants the epidermis, as a rule, is very thick and has a clense cuticle, thereby preventing loss of water.

There are various outgrowths of the cfidcmis. Hairs are the chief of these. They may be (I) simple, as on primula, geranium, nægelia; (2) once branched, as on wallflower; (3) compound, as on verbascum or mullein; (4) disk-like, as on shepherdia; (5) stellate, or star-shaped, as in certain crucifers. In some cases the hairs are glandular, as in Chinese primrose of the greenhouses (I'rimula Sincusis) and certain hairs of pumplin flowers. The hairs often protect the breathing pores, or stomates, from dust and water.

Stomates (sometimes called breathing-pores) ari small openings or porcs in the epidermis of leaves and soft stems 1.: : allow the passage of air and other gases and rapoursi (stomate or stoma, singular; stomates or stomata, plural). They are placed near the large intercellular spaces of the mesophyll, usually in positions least affected by direct 
sunlight. Fig. I 44 shows the structure. There are two guard-cells at the mouth of each stomate, which may in most cases open or close the passage as the conditions of the atmosphere may require. The guard-cells contain

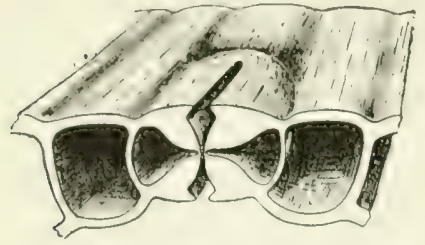

FIG. II4. - DIAGRAM OF STOMATE OF IRIS (Osterhout).

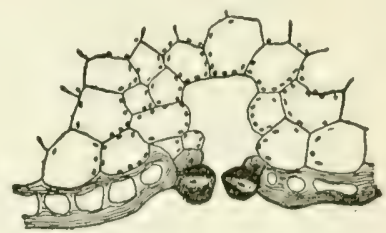

FIG. 115. - STOMATE OF IVY, showing compound guard-cells.

chlorophyll. In Fig. I I 5 is shown a case in which there are compound guard-cells, that of ivy. On the margins of certain leaves, as of fuchsia, impatiens, cabbage, are openings known as water-pores.

Stomates are very mumcrous, as will be seen from the numbers showing the pores to each square inch of leaf surface:

\begin{tabular}{|c|c|c|c|c|c|c|c|c|c|}
\hline & & & & & & & & Lower surface & Upper surfac \\
\hline Peony & . . & . . & - & . & - & . & • & . 13,790 & None \\
\hline Holly & . . & . . & . . & . & - & . & . & . 63,600 & None \\
\hline Lilac & . . & . . & . . & . & . & . & . & . I60,000 & None \\
\hline Mistlet & oe . & . & . & . & . & . & . & 200 & 200 \\
\hline Tradesc & cantia & a. . & . . & . & . & . & . & 2,000 & 2,000 \\
\hline Garden & Flag & (iris) & s). & . & . & . & . & . $\quad \mathrm{II}, 572$ & I I, 572 \\
\hline
\end{tabular}

The arrangement of stomates on the leaf differs with each kind of plant. Fig. I I6 shows stomates and also the

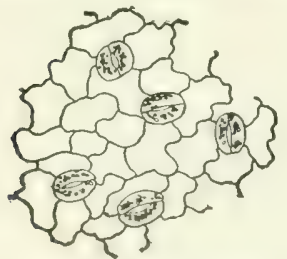

FIG. II OF GERANIUM LEAF. outlines of contiguous epidermal cells.

The function or work of the stomates is to regulate the passage of gases into and out of the plant. The directly active organs or parts are guard-cells, on either side the opening. One method of opening is as follows: The 
thicker walls of the guard-cells (Fig. II 4 ) absorb water from adjacent cells, these thick walls buckle or bend and part from one another at their middles on either side the opening, causing the stomate to open, when the air gases may be taken in and the leaf gases may pass out. When moisture is reduced in the leaf tissue, the guard-cells part with some of their contents, the thick walls straighten, and the faces of the two opposite ones come together, thus closing the stomate and preventing any water vapour from passing out. When a leaf is actively at work making new organic componnds, the stomates are usually open; when unfavourable conditions arise, they are usually closed. They also commonly close at night, when growth (or the utilizing of the new materials) is most likely to be active. It is sometimes safer to fumigate greenhouses and window gardens at night, for the noxious vapours are less likely to enter the leaf. Dust may clog or cover the stomates. Rains benefit plants by washing the leaves as well as by providing moisture to the roots.

Lenticels. - On the young woody twigs of many plants (marked in osiers, cherry, birch) there are small corky spots or eleva-

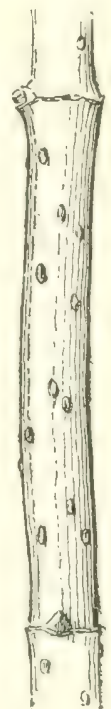

FIG. II7. - LEN-

TICEIS ON

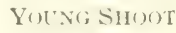
OF REI USIER (CURNLS). tions known as lenticels (Fig. II 7). They mark the location of some loose cork cells that function as stomates, for grecn shoots, as well as leaves, take in and discharge gases; that is, soft green twigs funtion as leaics. Under some of these twig stomates, corky material may form and the opening is torn and enlarged: the lenticels are sucessors to the stomates. The stomates lie in the epi- 
dermis, but as the twig ages the epidermis perishes and the bark becomes the external layer. Gicases continue to fors in and ont through the lenticels, until the branch becomes heavily covered with thick, corky bark. With the growth of the twig, the lenticel scars enlarge lengthwise or crosswise or assume other shapes, often becoming characteristic markings.

Fibro-vascular Bundles. - We have studied the fibrovascular bundles of stems (Chap. X). These stem bundles contimuc into the leaves, ramifying into the reins, carrying the soil water inwards and bringing, by diffusion, the elaborated food out through the sieve-cells. Cut across a petiole and notice the hard spots or areas in it; strip these parts lengthwise of the petiole. What are they?

Fall of the Leaf. - In most common deciduous plants, when the season's work for the leaf is ended, the nutritious matter may be withdrawn, and a layer of corky cells is completcd over the surface of the stcm where the leaf is attached. The leaf soon falls. It often falls even before it is killed by frost. Deciduous leaves begin to show the surface line of articulation in the early growing season. This articulation may be observed at any time during the summer. The area of the twig once covered by the petioles is called the leaf-scar after the leaf has fallen. In Chap. XV are shown a number of leaf-scars. In the plane tree (sycamore or buttonwood), the leaf-scar is in the form of a ring surrounding the bud, for the bud is covered by the hollowed end of the petiole; the leaf of sumac is similar. Examine with a hand lens leaf-scars of several woody plants. Note the number of bundle-scars in each leaf-scar. Sections may be cut through a leaf-scar and examined with the microscope. Note the character of cells that cover the leafscar surface. 
Suggestions. - To study epidermal hairs: 75. For this study, use the leaves of any hairy or woolly plant. A good hand lens will reveal the identity of many of the coarser hairs. A dissecting microscope will show them still better. For the study of the cell structure, a compound microscope is necessary. Cross-sections may be made so as to bring hairs on the edge of the sections; or in some cases the hairs may be peeled or scraned from the epidermis and placed in water on a slide. Make sketches of the different kinds of hairs. 76. It is good practice for the pupil to describe leaves in respect to their covering: Are they smooth on both surfaces? Or hairy? Woolly? Thickly or thinly hairy? Hairs long or short? Standing straight out or lying close to the surface of the leaf ? simple or branched? Attached to the veins or to the plane surface? Colour? Most abundant on young leaves or old? 77. Place a hairy or woolly leaf under water. Does the hairy surface appear silvery? Why? Other questions: 78. Why is it good practice to wash the leaves of house plants? 79. Describe the leaf-scars on six kinds of plants: size, shape, colour, position with reference to the bud, bundle-scars. 80. Do you find leaf-scars on monocotyledonous plants - corn, cereal grains, lilies, canna, banana, palm, bamboo, green brier? 81. Note the table on page $\mathbf{8 8 .}$ Can you suggest a reason why there are equal numbers of stomates on both surfaces of leaves of tradescantia and flag, and none on upper surface of other leaves? Suppose you pick a leaf of lilac (or some larger leaf), seal the petiole with wax and then rub the under surface with vaseline; on another leaf apply the vaseline to the upper surface; which leaf withers first, and why? Make a similar experiment with iris or blue flag. 82. Why do leaves and shoots of house plants turn towards the light? What happens when the plants are turned around? 83. Note position of leaves of beans, clover, oxalis, alfalfa, locust, at night. 


\section{CHAPTER XIII}

\section{LEAVES - FUNCTION OR WORK}

WE have discussed (in Chap. VIII) the work or function of roots and also (in Chap. X) the function of stems. We are now ready to complete the view of the main vitai activities of plants by considering the function of the green parts (leaves and young shoots).

Sources of Food. - The ordinary green plant has but two sources from which to sciure food, - the air and the soil. When a plant is thoroughly dried in an oven, the water passes off ; this watcr came from the soil. The remaining part is called the dry substance or dry matter. If the dry matter is burned in an ordinary fire, only the ash remains; this ash came from the soil. The part that passed off as gas in the burning contained the elements that came from the air; it also contained some of those that came from the soil - all those (as nitrogen, hydrogen, chlorine) that are transformed into gases by the heat of a common fire: The part that comes from the soil (the ash) is small in amount, being considerably less than ro per cent and sometimes less than I per cent. Water is the most abundant single constituent or substance of plants. In a corn plant of the roasting-ear stage, about 80 per cent of the substance is water. A fresh turnip is over 90 per cent water. Fresh wood of the apple tree contains about 45 per cent of water.

Carbon. - Carbon enters abundantly into the composition of all plants. Note what happens when a plant is burned 
without free access of air, or smothered, as in a charcoal pit. A mass of charroal remains, almost as large as the body of the plant. Charcoal is almost pure carbon, the ash present being so smali in proportion to the large amount of carbon that we look on the ash as an impurity. Nearly half of the dry substance of a tree is carbon. Carbon goes off as a gas when the plant is burncel in air. It does not gro off alone, but in combination with oxygen in the form of carbon dioxide gas, $\mathrm{CO}_{2}$.

The green plant secures its carbon from the air. In othere words, much of the solid matfer of the plant comes from one of the gases of the air. By volume, carbon atioxitle forms only a small fraction of 1 per cent. of the air. It would he very disastrous to animal life, however, if this perentage were much increased, for it exrludes the lifegiving oxygen. Carhon dioxide is often called "foul gas." It may aecumulate in old wells, and an experienced person will not descend into such wells until they have been tested with a torch. If the air in the well will not support "ombustion,-- that is, if the forch is extinguished,-it usually means that earbon dioxide has drained into the place. The air of a closed schoolroom often contains far too much of this gals, along with little solid particles of waste matters. Carbon dioxide is often known as carbonic acid gas.

Appropriation of the Carbon.-The cerlow diexide of the air readily diffuses itself into the leaves and other grecn parts of the plant. The leaf is delicate in texture, and when very young the air can diffuse directly into the tissues. The stomates, however, are the special inlets adapted for the admission of gases into the leaves and other green parts. Through these stomates, or diffusion-pores, the outside air enters into the air-spaces of the plant, and is finally absorbed by the little cells containing the living matter. 
Chloroinyll ("leat" green") is the agent that secures the eneley he moats of which rathon dioxide is utilized. This material is contaned in the leate renls in the form of

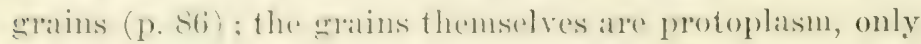
the coloming matter heing ehlorophyll. The chlorophyll buties ar grains ane oflen most abundant near the npper sulf fue of the liaf, where they can secure the greatest ammont. of light. Without this green rolouring matter, there would he no reason for the lalege flat surfaces which the leaves possess, and no reason for the fact that the lealves are horne most ahumdantly at the ends of hranches, where the light is most avaibule. Plants with coloured leares as coleus, have chloroplyyl, but it is masked by other colouring matter. This other colouring matter is usually soluble in hot water: hoil a coleus leaf and notice that it heromes green and the water becomes coloured.

I'lants grmen in darliness are yellow and slender, and do not rach maturity. Compare the potato sprouts that have grown from a tuber lying in a dark cellar with thoses that have grown normally in the bright light. The shoots have become slender, and are devoid of chlorophyll; anc? when the food that is stored in the tuber is exlausted these shoots will have lived useless lives. A plant that has been gromn in darkiness from the seed will soon die, although for a time the little seedling will grow very tall and slender. Why ? Light farours the production of chlormphyll, and the chlorophyll is the agent in the making of the orgunic carbon compounds. Sometimes chlorophyll is found in buds and seeds, but in most cases these places are not perfectly dark. Notice how potato tubers develop chlorophyil, or hecome green, when exposed to light.

Photosynthesis.-Carbon dirrirte diffuses into the leaf; during sumlight it is userl, and oxygen is given off. How 
the carbon dioxide which is thus absorbed may be used in making an organic food is a complex question, and need not be studied here; but it may be stated that cartom dioside and water are the constituents. Complex compounds are built up out of simpler ones.

chlorophyll absorbs certain light rays, and the cuncrgy thess directly or indirectly whenined is used by the living matter in uniting the carbon dioxide absorbed from the air with some of the water brought up from the roots. The ultimate result usually is starch. The process is olsirure, but sugar is generally one step; and our first definite knowledge of the product hegins when starch is deposited in the leaves. The process of using the carton dioxide of the air has been known as earhon assimilation, but the trem now most used is photosynthesis (from two Greek words meaning light and placing together.)

Starch and Sugar.-1ll sterch is composed of carlon, Buydroyen, and orygen $\left(\mathrm{C}_{6} \mathrm{II}_{10} \mathrm{O}_{5}\right)_{n}$. The sugars and the substance of "ell walls are very similar to it in composition. All these sulustances are called carbohydrates. Tn making fruit sugal from the earlon and oxygen of (atrbon dioxide. and from the hydrogen and oxygen of the water, three is a surplus of orygen (6 parts $(\mathrm{O} .2+6$ parts $\mathrm{II}$ O $\left.=\mathrm{C}_{6} \mathrm{I}_{12} \mathrm{O}_{6}+6 \mathrm{O}_{22}\right)$. It is this oxygen that is given off into the air during sunlight.

Digestion. - starch is in the form of insoluble gramules. When such food material is carried frome one part of the plant to another for purposes of grouth or storage, it is made soluble before it can be transported. Then this starchy material is transferred from place to place, it is usually changed into sugar by the action of a diastase. This is a process of digestion. It is much like the change of starchy foodstuffes to sugary foods effereted hy the saliva. 
Distribution of the Digested Food. - $\Lambda$ fter being changed to the soluble form, this mativial is reaty to be nsed in sroith, either in the leaf, in the stem, or in the roots. With other more complex products it is then distributed

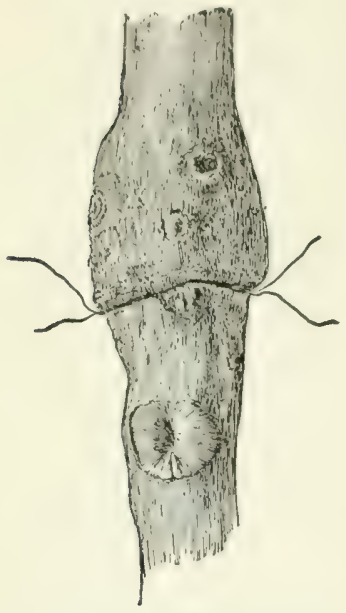

FIG, II8. - TRUNK GIRILEI)

BY A WIRE. See Figg. 85 . throughout all the growing parts of the plant; and when passing down to the root, it seems to pass more readily through the inner bark, in plants which have a definite bark. This gradual downward diffusion through the inner bark of materials suitable for growth is the process referred to when the "descent of sap" is mentioned. Starch and other products are often stored in one growing season to be used in the next season. If a tree is constricted or strangled by a wire around its trunk (Fig. I I S), the digested food cannot readily pass down and it is stored above the girdle, causing an enlargement.

Assimilation. - The food from the air and that from the soil mite in the living tissucs. The "sap" that passes upwards from the roots in the growing season is made up largely of the soil water and the salts which have been absorbed in the diluted solutions ( 1.67 ). This upwardmoving water is conducted largely through certain tubular canals of the young wood. These cells are never continuous tubes from root to leaf; but the water passes readily from one cell or canal to another in its upward course.

The upward-moving water gradually passes to the growing parts, and everywhere in the living tissues, it is, of 
course, in the most intimate contact with the soluble carbohydrates and products of photosynthesis. In the building up or reconstructive and other processes it is therefore available. We may properly conceive of certain of the simpler organic molecules as passing through a series of changes, gradually increasing in complexity. There will be formed substances containing nitrogen in addition to carbon, hydrogen, and oxygen. Others will contain also sulphur and phosphorus, and the various processes may be thought of as culminating in protoplasm. Protoplasm is the living matter in plants. It is in the cells, and is usually semifluid. Starch is not living matter. The complex process of building up the protoplasm is called assimilation.

Respiration. - Plants need orygen for respiration, as animals do. We have seen that plants need the carbon dioxide of the air. To most plants the nitrogen of the air

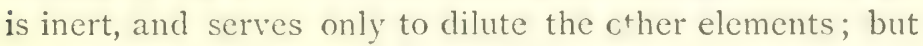
the orygin is necssary for all life. IVe know that all animals need this oxygen in order to breathe or respire. In fact, they have become accustomed to it in just the proportions found in the air; and this is now best for them. When animals breathe the air once, they make it foul, because they use some of the oxygen and give off carbon diuxide. Liliewise, all lizing parts of the plant must hav'e a constant supply of oxysen. Roots also need it, for they respire. Air goes in and out of the soil by diffusion, and as the soil is heated and cooled, causing the air to expand and contract.

The oxygen passes into the air-spaces and is absorbed by the moist cell membranes. In the living cells it makes possible the formation of simpler compounds by which energy is released. This energy enables the plant to 
work and grow, and the final products of this adetion are entuen dierible and reater. As a result of the use of this oxyen hy night and hy day, plants grive offe carlon dioxide. Plents resprive: but since they are stationary, and more or

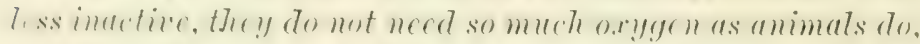

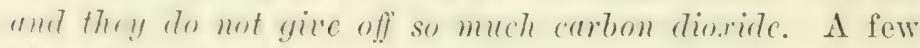
plants in a sleeping room need not disturb one more than a family of mice. It should he noted, howerer, that germinating seeds respire vigorous!y, hene they ansume much oxygen; and opening buds and flowers are likewise active.

Transpiration. - Much more water is absorbed by the roots than is used in growth, and this suphlus water passes from the lcaics into the atmospluere by an ciaporation process knuan as transpiration. Transpiration takes place more abundantly from the under surfaces of leaves, and through the pores or stomates. A sumflower plant of the height of a man, during an active period of growth, gives off a quart of water per day. A large oak tree may transpire I 50 gallons per day during the summer. For every ounce of dry matter produced, it is estimated that 15 to 25 pounds of water usually passes through the plant.

When the roots fail to supply to the plant sufficicnt watcr to cqualize that transpired by the leares, the plant wilts. Transpiration from the leaves and delicate shoots is increased hy all the conditions which increase evaporation, such as higher temperature, dry air, or wind. The stomata open and close, tending to regulate transpiration as the varying conditions of the atmosphere affect the moisture content of the plant. However, in periods of drought or of very hot weather, and especially during a hot wind, the closing of these stomates cannot sufficiently prevent evaporation. The roots may be very active and yet fail to absorb sufficient moisture to equalize that given 
off by the leaves. The plant shows the effect (how?). On a hot dry day, note how the leaves of corn "roll." towards afternoon. Note how fresh and vigorous the same leaves appear early the following morning. Any injury to the roots, such as a bruise, or exposure to heat, drought, or cold may cause the plant to wilt.

Water is forced up by root pressure or sap pressure. (Exercise 99.) Some of the dew on the grass in the morning may be the water forced up by the roots; some of it is the condensed vapour of the air.

The wilting of a plant is due to the loss of water from the cells. The cell walls are soft, and collapse. A toy balloon will not stand alone until it is inflated with air or liquid. In the woody parts of the plant the cell walls may be stiff enough to support themselves, even though the cell is empty. Measure the contraction due to wilting and drying by tracing a fresh leaf on page of notebook, and then tracing the same leaf after it has been dried between papers. The sufter the leaf, the greater will be the contraction.

Storage. - We have said that starch may be stored in twigs to be used the following year. The very early flowers on fruit trees, especially those that come before the leaves, and those that come from bulbs, as crocuses and tulips, are supported by the starch or other food that was organized the year before. Some plants have very special storage reservoirs, as the potato, in this case being a thickened stem although growing underground. (Why a thickened stem? p. S4.) It is well to make the starch test on winter twigs and on all kinds of thickened parts, as tubers and bulbs.

Carnivorous Plants. - Certain plants capture insects and other very small animals and utilize them to some extent as food. Such are the suncew, which has on the leaves 


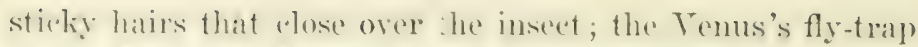
of the Southern States, in which the halves of the leaves

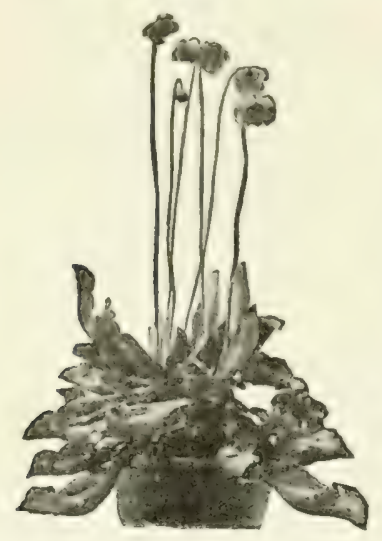

FIG. II9. - THE CUMMON Pitcher Plant (Sarracenia purpurea) showing the tubular leaves and the odd, long-stalked nuwers. close over the prey like the jaws of a steel trap; and the various kinds of pitcher plants that collect insects and other organic matter in deep, water-filled, flasklike leaf pouches (Fig. I 19).

'The sundew and the Venus's fly-trap are sensitive to contact. Other plants are sensitive to the touch without being insectivorous. The common cultivated sensitive plant is an example. This is readily grown from seeds (sold by seedsmen) in a warm place. Related wild plants in the south are sensitive. The utility of this sensitiveness is not understood.

Parts that Simulate Leaves. - We have learned that leaves are endlessly modified to suit the conditions in which the plant is placed. The most marked modifications are in adaptation to light. On the other hand, other organs oftcn perform the functions of leares. Green shoots function as leaves. These shoots may look like leaves, in which case they are called cladophylla. The foliage of common asparagus is made up of fine branches: the real morphological leaves are the minute dry functionless scales at the bases of these branchlets. (What reason is there for calling them leaves?) The broad "leaves" of the florist's smilax are cladophylla. Where are the leaves on this plant? In most of the cacti, the entire plant body performs the functions of leares until the parts become cork-bound. 


\section{Leaves are sometimes modified to perform other functions} than the vital processes: they may be tendrils, as the terminal leaflets of pea and sweet pea; or spines, as in barberry. Not all spines and thorns, however, represent modified leaves: some of them (as of hawthorns, osage orange, honey locust) are branches.

Suggestions.-To test for chlorophyll. 84. Purchase about a gill of rood alcohol. Secure a leaf of geranium, elover, or other plant that has been exposed to sunlight for a few hours, and, after dipping it for a minute in boiling water, put it in a white eup with sufficient alcohol to cover. Place the eup in a shallow pan of hot water on the stove where it is not hot enough for the alcohol to take fire. After a time the chlorophyll is dissolved by the alcohol which has become an intense green. Save this leaf for the starch experiment. (Exercise 85). Without chlorophyll, the plant cannot appropriate the carbon dioxide of the air. Starch and photosynthesis. 85. Stareh is present in the green leaves which have been exposed to sunlight; but in the dark no starch can be formed from carbon dioxide. Apply iodine to the leaf from which the chlorophyll was dissolved in the previous experiment. Note that the leat' is aloured purplish-brown throughout. The lait coniains starch. 86. Secure a leaf from a plant which has been in the dark for about two days. Dissolve the chlorophyll as before, and attempt to stain this leaf with iodine. No purplish-brown colour is produced. This shows that the stareh manufactured in the leaf may be entirely removed during darkness. 87. Secure a plant which has been kept in darkness for trenty-folir hours or more. Split a small cork

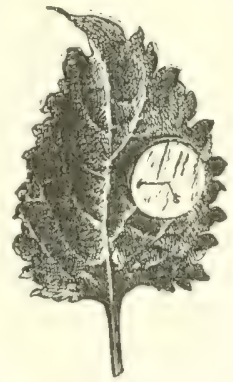

FIG. I20. - ExCLUDING LIGHT AND $\mathrm{CO}_{2}$ FROM PART OF A LEAF.

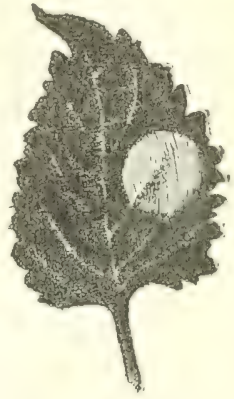

FIG. I2I. - TIIE RESULT. and pin the two halves on opposite sides of one of the leaves, as shown in Fig. 120. Place the plant in the sunlight again. After a morning of bright sunshine dissolve the chlorophyll in this leaf with aleohol; then stain the leaf with the iodine. Notice that the leaf is staines leeply except whera the cork was; there sunlight aml carbon dioxide were excluded, Fig. 121. There is no stareh in the 
covered area. 88. Plants or parts of plants that have developed no chlorophyll can form no starch. Secure a variegated leaf of coleus, ribbon grass, geranium, or of any plant showing both white and green areas. On a day of bright sunshine, test one of these leaves by the alcohol and iodine method for the presence of starch. Observe that the parts devoid of green colour have formed no starch. However, after starch has once been formed in the leaves, it may be changed into soluble substances and removed, to be again converted into starch in certain other parts of the living tissues. To test the gizing off of oxygen by day. 89. Make the experiment illustrated in Fig. I22. Under a funnel in a deep glass jar containing fresh spring or stream water place fresh pieces of the common waterweed elodea (or anacharis). Have the funnel considerably smaller than the vessel, and support the funnel well up from the bottom so that the plant can more readily get all the carbon dioxide available in the water. Why would boiled water be undesirable in this experiment? For a home-made glass funnel, crack the bottom off a narrow-necked bottle by pressing a red-hot poker or iron rod against it and leading the crack around the bottle. Invert a testtube over the stem of the funnel. In sunlight bubules of oxygen will arise and collect in the test-tube. If a sufficient quantity of oxygen has collected,

a lighted taper inserted in the tube will glow with a brighter flame, showing the presence of oxygen in greater quantity than in the air. Shade the vessel. Are bubbles given off? For many reasons it is impracticable to continue this experine't loser than a few hours. 90. A simpler experiment may be made if one of the waterweeds Cabomba (water-lily family) is available. Tie a number of branehes together so that the basal ends shall make a small bundle. Place these in a large vessel of spring water, and insert a test-tube of water as before over the bundle. The bubbles will arise from the cut surfaces. Observe the bubliles on pond scum and waterweeds on a bright day. TJ illustrate the results of respiration 
$\left(\mathrm{CO}_{2}\right)$. 91. In a jar of germinating seeds (Fig. 1 23) place carefully a small dish of limewater and cover tightly. Put a similar dish in

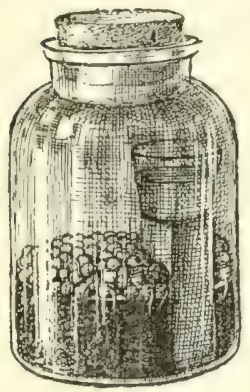

FIG. I23.- TO ILLUSTRATE A PRODUCT OF RESPIRATION. another jar of about the same air space. After a few hours compare the cloudiness or precipitate in the two vessels of limewater. 92. Or, place a growing plant in a deep covered jar away from the light, and after a few hours insert a lighted candle or splinter. 93. Or, perform a similar experiment with fresh roots of beets or turnips (Fig. I24) from which the leaves are mostly removed. In this case, the jar need not be kept dark; why? To test transpiration. 94. Cut a succulent

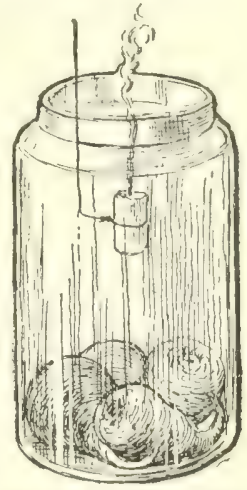

FIC. 12t.- RISPIRATION OF 'THICK RoOTs. shoot of any plant, thrust the end of it through a hole in a cork, and stand it in a small bottle of water. Invert over this a fruit jar, and observe that a mist soon accumulates on the inside of the glass. In time drops of water form. 95. The experiment may be varied as shown in Fig. I 25. 96. Or, invert the fruit jar over an entire plant, as shown in Fig. I 26, taking care to cover the soil with oiled paper or rubber cloth to prevent evaporation from the soil. 97. The test may also be made by placing the pot, properly protected, on bal-

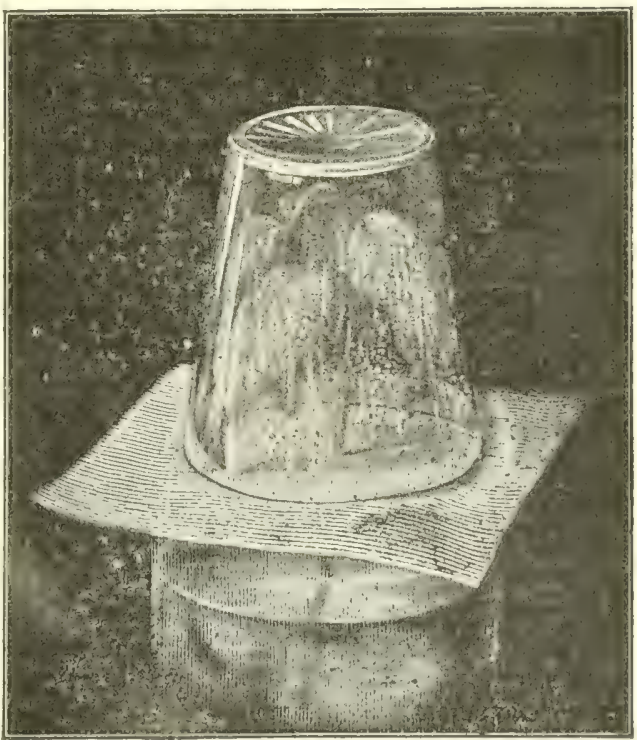

Fig. i25. - To illustrate Transpiration. 
ances, and the loss of weight will be noticed (Fig. I27). 98. Cut a winter twig, seal the severed end with wax, and allow the twig to lie several diys. It shrivels. There must be some upward movement of water even in winter, else plants would shrive! and die. 99. To illustrate sap pressure.

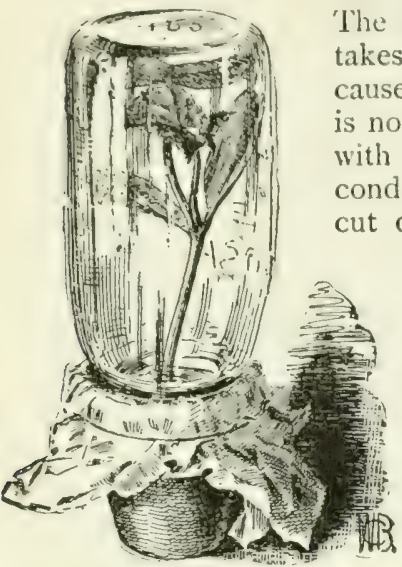

FIG. 126. - TO ILLUSTRATE

TRANSPIRATION. The upward movement of sap water often takes place under considerable force. The cause of this force, known as root pressure, is not well understood. The pressure varies with different plants and under different conditions. To illustrate: cut off a strong-growing small plant near the ground. By means of a bit of rubber tube attach a glass tube with a bore of approximately the diameter of the stem. Pour in a little water. Observe the rise of the water due to the pressure from be-

low (Fig 128). Some plants yield a large amount of water under a pressure sufficient to raise a column several feet; others force

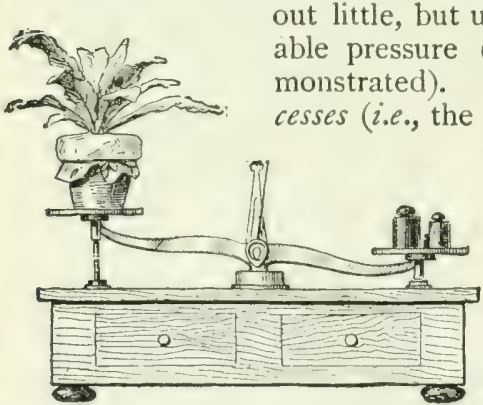

HIG. I27 - LOSS OF WATER. (less easily deThe vital pro100 . The pupil having studied roots, stems, and leaves, should now be able to describe the main vital functions of plants : what is the root function? stem function? leaf function? 101. What is meant by the "sap"? 102. Where and how does the plant secure its water? oxygen? carbon? hydlogen? nitrogen? sulphur? potassium?

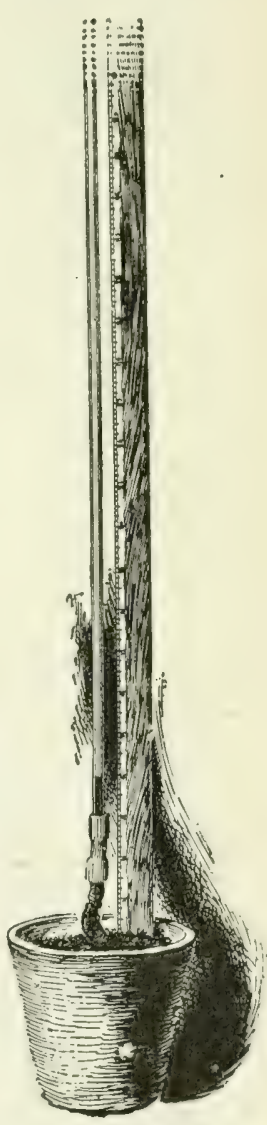

FIG. I28. - TO SHOW SAP PRESSURE. 
alcium? iron? phosphorus? 103. Where is all the starch in the world made? What does a starch-factory establishment do? Where are the real starch factories? 104. In what part of the tiventy-four hours do plants grow most rapidly in length? When is food formed and stored most rapidly? 105. Why does corn or cotton turn yellow in a long rainy spell? 106. If stubble, corn stalks, or cotton stalks are burned in the field, is as much plant-food returned to the soil as when they are ploughed under? 107. What process of plants is roughly analogous to perspiration of animals? 108. What part of the organic world uses raw mineral for food? 109. Why is earth banked over celery to blanch it? 110. Is the amount of water transpired equal to the amount absorbed? 111. Give. some reasons why plants very close to a house may not thrive or may even die. 112. Why are fruit-trees pruned or thinned out as in Fig. I29? Proper balance between top and root. 113. We have learned that the leaf parts and the root parts work together. They may be said to balance each other in activities, the root supplying the top and the top supplying the root (how?). If half the roots were cut from a tree, we should expect to reduce the top also, particularly if the tree is being transplanted. How would you prune a tree or

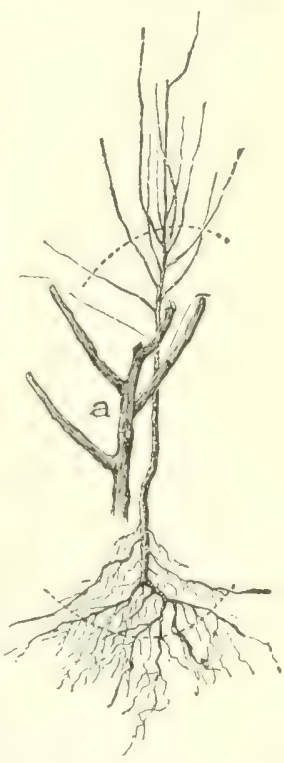

Fig. 130. - AN APPLE TREE, with suggestions as to pruning when it is set in the orchard. At $a$ is shown a pruned top. bush that is being transplanted? Fig. I 30 may be suggestive.
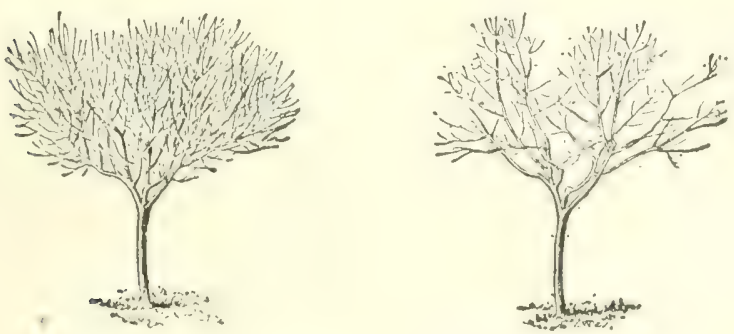

FIG. I29. - BEFORE AND AFTER PRUNING. 


\section{CHAPTER XIV}

\section{DEPENDENT PLANTS}

Thus far we have spoken of plants that have roots and foliage and that depend on themselves. They collect the raw materials and make them over into assimilable food. They are independent. Plants without green foliage can-

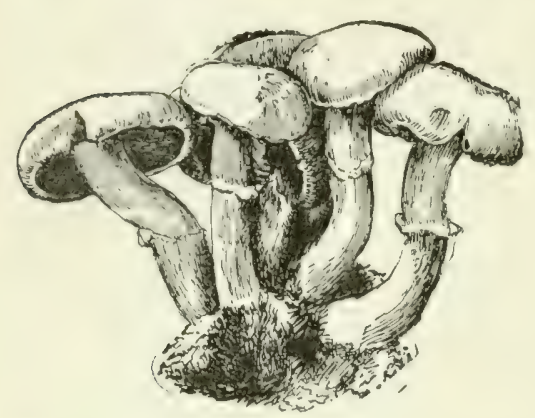

FIG. 13I. - A MUshroom, example of a saprophytic plant. This is the edible cultivated mushroom. not make food; they must have it made for them or they die. They are dependent. A sprout from a potato tuber in a dark cellar cannot collect and elaborate carbon dioxide. It lives on the food stored in the tuber.

All plants with natnrally white or blanched parts are dependent. Their leaves do not develop. They live on organic matter - that which has been made by a plant or elaborated by an animal. The dodder, Indian pipe, beech drop, coral root among flower-bearing plants, also mushrooms and other fungi (Figs. I3 I, 132) are examples. The dodder is common in swales, being conspicuous late in the season from its thread-like yellow or orange stems spreading over the herbage of other plants. One lind attacks alfalfa and is a bad pest. The seeds germinate in the spring, but as soon as the twining stem a:106 


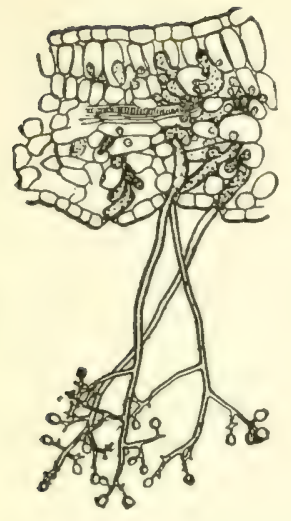

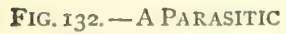
FUNGUS, magnified. The mycelium, or vegetative part, is shown by the dottedshaded parts ramifying in the leaf tissue. The rounded haustoria projecting into the celis are also shown. The long fruiting parts of the fungus hang from the under surface of the leaf.

taches itself to another plant. the dodder dies away at the base and becomes wholly dependent. It produces flowers in clusters and seeds itself freely (Fig. 133).

Parasites and Saprophytes. - A plant that is dependent on a living plant or animal is a parasite, and the plant or animal on which it lives is the host. The dodder is a true parasite; so are the rusts, mildews, and other fungi that attack leaves and shoots and injure them.

The threads of a parasitic fungus usually creep through the intercellular spaces in the leaf or the stem and send suckers (or haustoria) into the cells (Fig. I32). The threads (or the hyphæ) clog the air-spaces of the leaf and often plug the stomates, and they also appropriate and disorganize the cell fluids; thus they injure or kill their host. The mass of hyphe of a fungus is called mycelium. Some of the hypha finally grow out of the leaf and produce spores or reproductive cells that answer the purpose of seeds in distributing the plant (b, Fig. 132).

A plant that lives on dead or decaying matter is a saprophyte. Mushrooms (Fig. I3I) are examples; they live on the decaying matter in the soil. Mould on bread and cheese is an

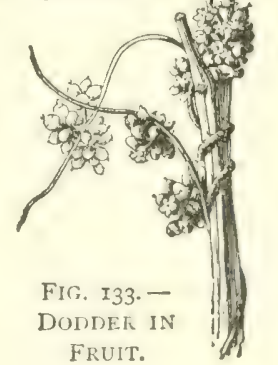


example. Lay a piece of moist bread on a plate and invert a tumbler over it. In a fiew days it will be mouldy. The spores were in the air, or perhaps they had already fallen on the bread but had not had opportunity to grow. Most green plants are unable to make any clirect use of the humus or vegetable mould in the soil, lor they are not

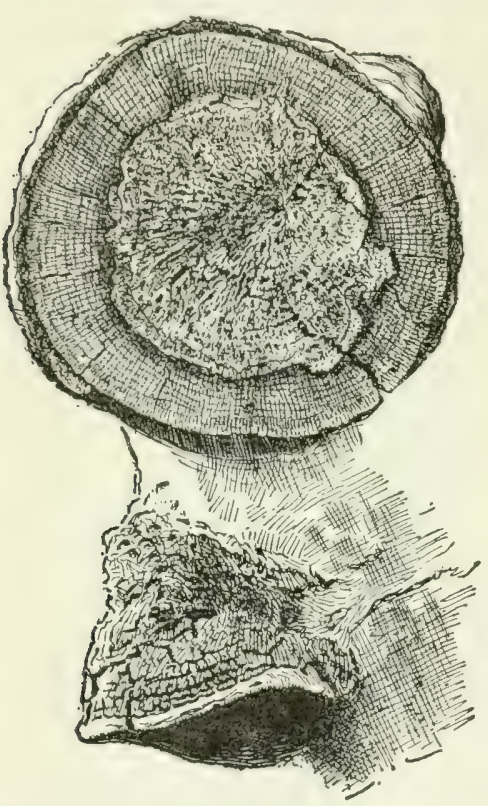

FIG. I34. - Tinder Fungus (Polyporus ignuarius) on beech log. The external part of the fungus is shown below; the heart-rot injury above. saprophytic. The shelffungi (Fig. I34) are saprophytes. They are common on logs and trees. Some of them are perhaps partially parasitic, extending the mycelium into the wood of the living tree and causing, it to become black-hearted (Fig. 1 34).

Some parasites spring from the ground, as other plants do, but they are parasitic on the roots of their hosts. Some parasites may be partially parasitic and partially saprophytic. Many (perhaps most) of these ground saprophytes are aided in securing their food by soil fungi, which spread their delicate threads over the root-like branches of the plant and act as intermediaries between the food and the saprophyte. These funguscovered roots are known as mycorrhizas (meaning "fungus root"). Mycorrhizas are not peculiar to saprophytes. They are found on many wholly independent plants, as, 
for exainple, the heaths, oaks, apples, and pines. It is probable that the fungous threads perform some of the offices of root-hairs to the host. On the other hand, the fungus obtains some nourishment from the nost. The association seems to be mutual.

Saprophytes break down or decompose organic substances. Chief of these saprophytes are many microscopic organ-

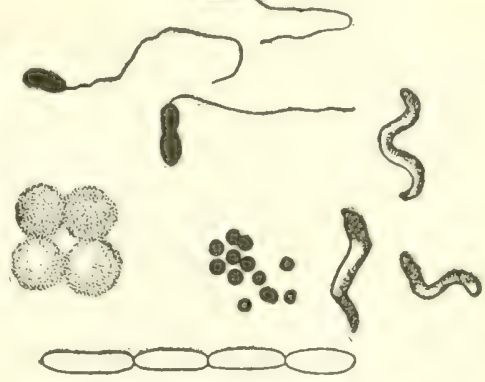

FIG. 135. - BACTERIA OF SEVERAL ForMS, much magnified. isms known as bacteria (Fig. I35). These innumerable organisms are immersed in water or in dead animals and

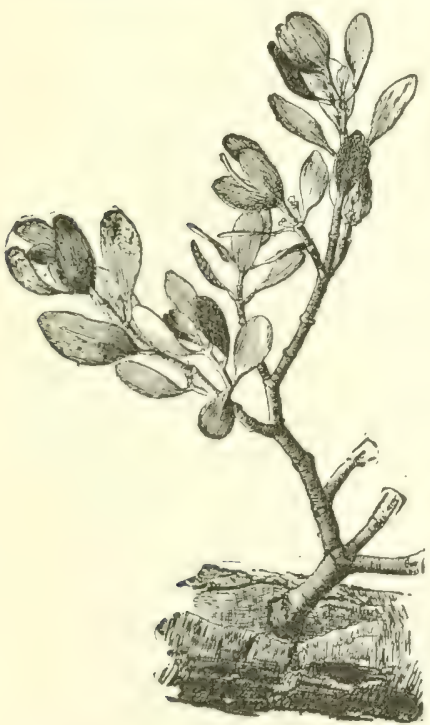

FIG. 136. - AMERICAN MISTLETOE GROWING ON A WALNUT BRANCH. plants, and in all manner of moist organic products. By breaking down organic combinations, they produce decay. Largely through their agency, and that of many true but microscopic fungi, all things pass into soil and gos. Thus are the bodies of plants and animals removed and the continuing round of life is maintained.

Some parasites are grecnleaved. Such is the mistletoe (Fig. I36). They anchor themselves on the host and absorb its juices, but they also appropriate and use 
the carbon dioxide of the air. In some small groups of bacteria a process of organic synthesis has been shown to take place.

Epiphytes. - To be distinguished from the dependent plants are those that grow on other plants without taking food from them. These are green-leaved plants whose roots burrow in the bark of the host plant and perhaps derive some food from it, but which subsist chiefly on materials that they secure from air dust, rain water, and the air. These plants are epiphytes (meaning "upon plants") or air plants.

Epiphytes abound in the tropics. Certain orchids are among the best known examples (Fig. 37). The Spanish moss or tillandsia of the South is another. Mosses and lichens that grow on trees and fences may also be called epiphytes. In the struggle for existence, the plants probably haie becn driven to these special places in which to find opportunity to grow. Plants grow where they must, not where they will.

Suggestions. - 114. Is a puffball a plant ? Why do you think so? 115. Are mushrooms ever cultivated, and where and how? 116. In what locations are mushrooms and toadstools usually found? (There is really no distinction between mushrooms and toadstools. They are all mushrooms.) 117. What kinds of mildew, blight, and rust do you know? 118. How do farmers overcome potato blight? Apple scab? Or any other fungous "plant disease"? 119. How do these things injure plants? 120. What is a plant disease? 121. The pupil should know that every spot or injury on a leaf or stem is caused by something, — as an insect, a fungus, wind, hail, drought, or other agency. How many uninjured or perfect leaves are there on the plant growing nearest the schoolhouse steps? 122. Give formula for Bordeaux mixture and tell how and for what it is used. 


\section{CHAPTER XV.}

\section{WINTER AND DORMANT BUDS}

A bud is a growing point, terminating an axis either long or short, or being the starting point of an axis. All branches spring from buds. In the growing season the bucl is active; later in the season it ceases to increase the axis in length, and as winter approaches the growing point becomes more or less thickened and covered by protecting scales, in preparation for the long resting season. This resting, dormant, or winter body is what is commonly spoken of as a "bud." A winter bud may be defined as an inactive covered growiing point, waiting for spring.

Structurally, a dormant bud is a shortened axis or branch, bearing miniature leases or flowers or voth, and protected by a covering. Cut in two, lengthwise, a bud of the horse-chestnut or other plant that has large buds. With a pin separate

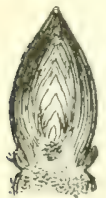

FIG. I37. - BUD OF APRICOT, showing the miniature leaves.

the tiny leaves. Count them. Examine the big bud of the rhubarb as it lies under the ground in late winter or early spring; or the crown buds of asparagus, hepatica, or other carly spring plants. Dis. sect large buds of the apple and pear (Figs. 137, I38).

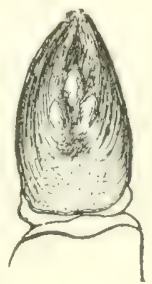

FIG. I38. - BUD OF PEAR, showing both leaves and flowers. The latter are the little knots in the centre.

The bud is protected by firm and dry scalcs. These scales are modified leaves. The scales fit close. Often 
the bud is protected by varnish (see horse-chestnut and the balsam poplars). Most winter buds are more or less woolly. Examine some of them under a lens. As we might expect, bud coverings are most prominent in cold and dry climates. Sprinkle water on velvet or flannel, and note the result and give a reason.

All winter buds give rise to branches, not to lcaves alonc; that is, the leaves are borne on the lengthening axis. Sometimes the axis, or branch, remains very short, - so short that it may not be noticed. Sometimes it grows several feet long.

Whether the branch growes large or not depends on the chance it has, - position on the plant, soil, rainfall, and
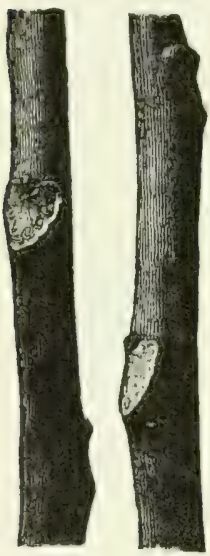

FIG. I39. - J.EAFmany other factors. The new shoot is the unfolding and enlarging of the tiny axis and leaves that we saw in the bud. If the conditions are congenial, the shoot may form more leaves than were tucked away in the bud. The length of the shoot usually depends more on the length of the internodes than on the number of leaves.

Where Buds are. - Buds are borne in the axils of the leaves, - in the acute angle that the leaf makes with the stem. When the leaf is growing in the summer, a bud is forming above it. When the leaf falls, SCARS. - Ailanthus. the bud remains, and a scar marks the place of the leaf. Fig. I 39 shows the large leaf-scars of ailanthus. Observe those on the horse-chestnut, maple, apple, pear, basswood, or any other tree or bush.

Sometimes two or more buds are borne in one axil; the extra ones are accessory or supernumerary buds. Observe them in the Tartarian honeysuckle (common in yards), 
walnut, butternut, red maple, honey locust, and sometimes in the apricot and peach.

If the bud is at the end of a shoot, however short the shoot, it is called a terminal bud. It continues the groweth of the axis in a direct line. Very often three or more buds are clustered at the tip (Fig. I40); and in this case there may be more buds than leaf scars. Only one of them, however, is strictly terminal.

A bud in the axil of a leaf is an axillary or lateral bud. Note that there is normally at least one bud in the axil of every leaf on a tree or shrub in late summer and fall. The axillary buds, if they grow, are the starting points of new shoots the following season. If a leaf is pulled off early in summer, what will become of the young bud in its axil? Try this.

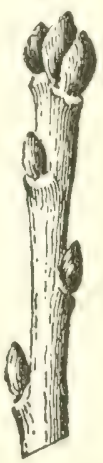

FIG. 1.90. - TERMINAL. BUI) BETWEEN TWO OTHER BULS. - Currant.

Bulbs and cabbage heads may be likencd to buds; that is, they are condensed stems, with scales or modified leaves

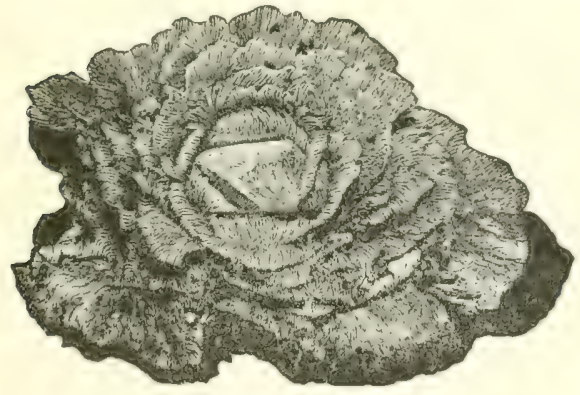

Fig. I4I. - A Gigantic Bud, - Cabbage. densely overlapping and forming a rounded body (Fig. I4I). They differ from true buds, however, in the fact that they are condensations of whole main stems rather than embryo stems borne in the axils of leaves. But bulblets (as of tiger lily) may be scarcely distinguishable from buds on the one hand and from bulbs 
on the other. Cut a cabbage head in two, lengthwise, and see what it is like.

The buds that appear on roots are unusual or abnormal, - the occur only occasionally and in no definite order. Buds appearing in unusual places on any part of the plant are called adventitious buds. Such usually are the buds that arise when a large limb is cut off, and

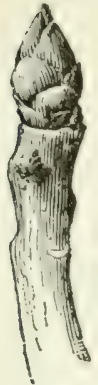

FIG. 142. -

FRUI'T-BUD OF PEAR.

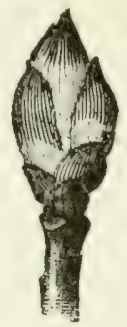

FIG. I43. - THE OPENING OF THE PEAR FRUIT-BUD. from which suckers fall very soon, lcaving a little ring of scars. With terminal buds, this ring marks the end or water sprouts arise.

How Buds Open. -When the bud swells, the scales are pushed apart, the little axis elongates and pushes out. In most plants the outside scales

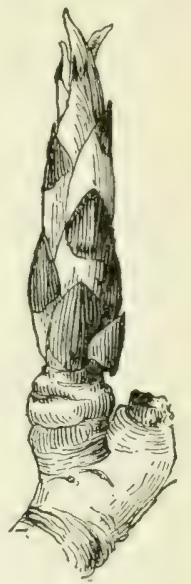
of the year's growth. How? Notice peach, apple, plum, willow, and other plants. In FIG. I44. - OPENING PEAR LEAF-BUD. some others, all the scales grow for a time, as in the pear (Figs. I42, I43, I44). In other plants the inner bud scales become green and almost leaf-like. See the maple and hickory.

Sometimes Flowers come out of the Buds. - I Leaves may or may not accompany the flowers. We saw the embryo flowers in

FIG. I45. - OPENING OF THE PEAR-BUD. Fig. I38. The bud is shown again in Fig. 142. In Fig. 143 it is opening. In Fig. I45 
it is more advanced, and the woolly unformed flowers are appearing. In Fig. I 46 the growth is more advanced.

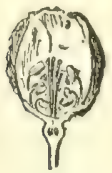

FIG. I46.-A SINGLE FLOWER IN THE PEAR CLUSTER, as seen at 7 A.M. on the day of its opening. At Io o'clock it will be fully expanded.

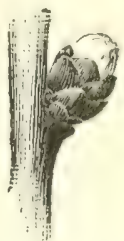

FIG. 147. - THE OPENING OF THE FLOWERBUD OF APRICOT.

Buds that contain or produce only leaves are

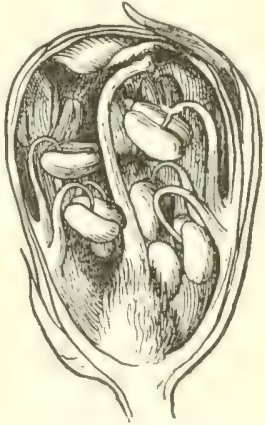

FIG. I48. - APRICOT FLOWER-BUD, enlarged.

leaf-buds. Those which contain only flowers are flowerbuds or fruit-buds. The latter occur on peach, almond, apricot, and many very early spring-flowering plants. The single flower is emerging from the apricot bud in Fig. 147. A longitudinal section of this bud, enlarged, is shown in Fig. 148. Those that contain both leaves and flowers are mixed buads, as in pear, apple, and most late springflowering plants.

Fruit buds are usually thicker or stonter than leaf-buds. They are borne in different positions on different plants. In some plants (apple, pear) they are on the ends of short branches or spurs; in others (peach, red maple) they are along the sides of the last year's growths. In Fig. I49 are shown

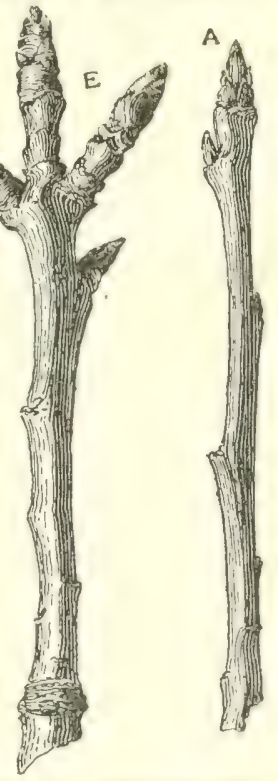


three fruit-buds and one leaf-bud on $F$, and leaf-buds on A. Sec also Figs. I 50, 151, I 52, I 53, and expliin.

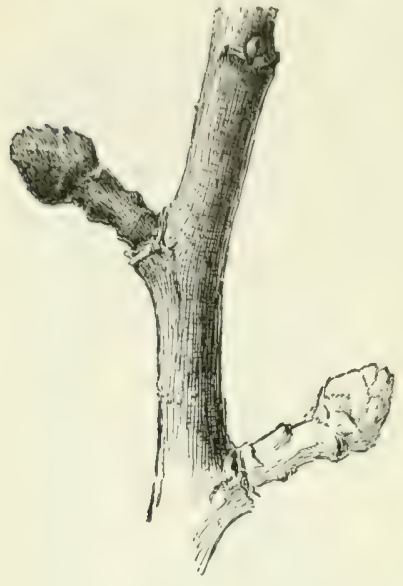

FiG. 150.- FRUIT-BUDS OF APPLE ON SPURS: a dormant bud at the top.

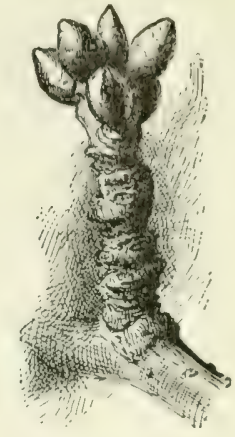

FIG. I5I. - CLUSTER OF FRUITBUDS OF SIVEET CHERRY, with on e pointed leaf-bud in centre.

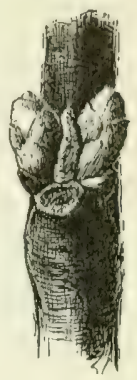

FIG. I52. - Two

FRUIT-BUDS OF PEACH with a leafbud between.

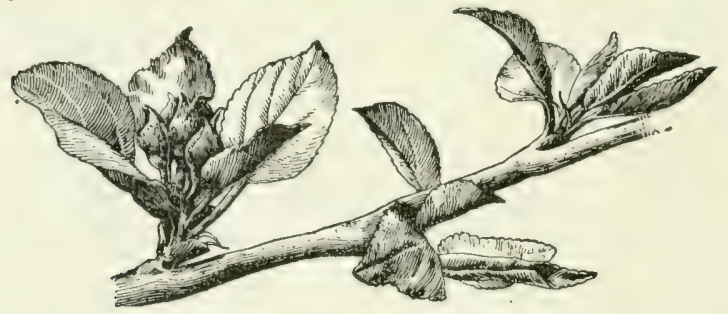

FIG. 153.- OPENING OF LEAF-BUDS AND FLOWER-BUDS OF APPLE.

"The burst of spring" means in large part the opening of the buds. Evcrything was made ready the fall before. The cmbryo shoots and flowers were tucked away, and the food was stord. The warm rain falls, and the shutters open and the sleepers wake.

Arrangement of Buds.-We have found that leaves are usually arranged in a definite order; buds are borne in the axils of leaves: therefore buds must cxhibit phyllotaxy. 
Moreover, branches grow from buds: branches, therefore, sinould show a definite arrangement. I sually, however, they do not show this arrangement because not all the buds grow crnel not all the branches liric. (See Chaps. II and III.) It is apparent, however, that the mode of arrangement of buds determines to some extent the form of the tree. Compare bud arrangement in pinc or fir with that in maple or apple.

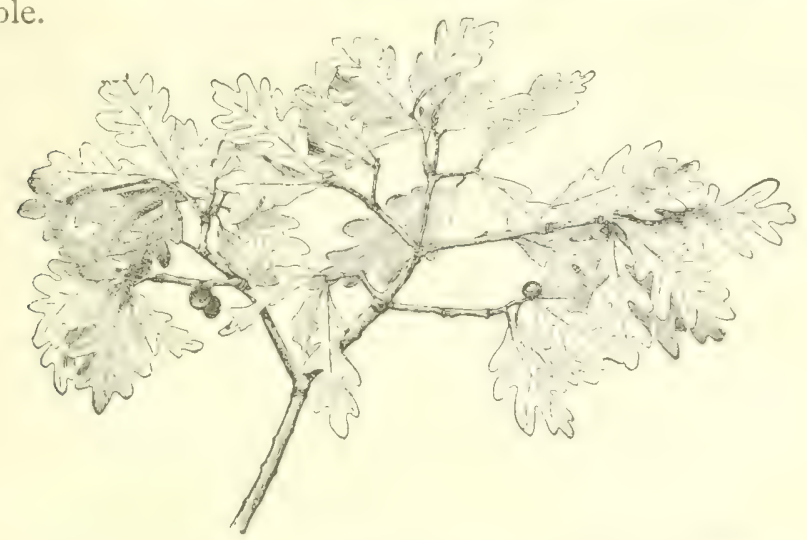

FIG. I5t--OAK SPRAY. How are the leaves borne with reference to the annual growths?

The uppermost buds on any twig, if they are well mitured, are usually the larger and stronger and they are the most likely to grow the next spring; therefore, branches tend to be arranged in ticrs (particularly well marked in spruces and firs). See Fig. 154 and explain it.

Winter Buas show what has been the Effect of Sunlight.Pucts are bolne in the axils of the leaves, and the size ir the rigener of the ?eaf etefermines lo alarge estent the siar of the bud. Notiere that, in linost instamess, the laryest burls wre merest the tip (Fig. 157). If the largest lunds are not men the tip, there is some special reason for it. Can you sate it? Ixamine the shoots on trees and bushes. 
Surifstroxs. - Some of the best of all observation lessons are those make on dormant twigs. There are many things to be learned, the eves are trained, and the specimens are everywhere accessible. 123. At whatever time of year the pupil takes up the study of branches, he should look for three things: the ages of the various parts, the relitive positions of the hurls and theleaves, the different sizes of similar or companable buds. If it is late in spring or early in summer, he should watch the development of the buds in the axils, and he should determine whether the strength or size of the bud is in any way related to the size and

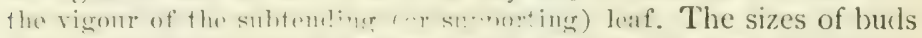
should also be noted on leafless twigs, and the sizes of the former leaves may be inferred from the size of the leaf-scar below the bud. The pupil should keep in mind the fact of the struggle for food and light, and its effects on the developing buds. 124. The bud and the branch. A twig cut from an apple tree in early spring is shown in Fig. 155. 'The most hasty observation shows that it has various parts, or members. It seems to be divided at the point $f$ into two parts. It is evident that the part from $f$ to $h$ grew last year, and that the part below $f$ grew two years ago. The buds on the two parts are very unlike, and these differences challenge investigation. - In order to understand this seemingly lifeless twig, it will be necessary to see it as it looked late last summer (and this condition is shown in Fig. 156). The part from $f$ to $h,-$ which has just completed its growth, - is seen to have its leaves growing singly. In every axil (or angle which the leaf makes when it joins the shoot) is a bud. The leaf starts first, and as the season advances the bud forms in its axil. When the leaves have fallen, at the approach of winter, the buds remain, as seen in Fig. 155. Every bud on the last year's growth of a winter twig, therefore, marks the position occupied by a leaf when the shoot was growing. - The part below $f$, in Fig. I 56 , shows a wholly different arrangement. The leaves are two or more together (anaa), and there are buds without leaves $(b, 3, h)$. A year ago this part looked like the present shoot from $f$ to $h$, - that is, the leaves were single, with a bud in the axil of each. It is now seen that some of these bud-like parts are longer than others, and that the longest ones are those which have leaves. It must he because of the leaves that they have increased in length. 'The body' $c$ has lost its leaves through some accident, and its growth has ceased. In other words, the parts at ada are like the shoot fh, except that they are shorter, and they are of the same age. One grew from the end or terminal bud of the main branch, and the others from the side or lateral buds. Parts or bodies that bear leaves are, therefore, branches. - The buds at $b 6 b b$ have no leaves, and they remain the same 
size that they were a year ago. They are dormant. The only way for a mature bud to grow is by making leaves for itself, for a leaf

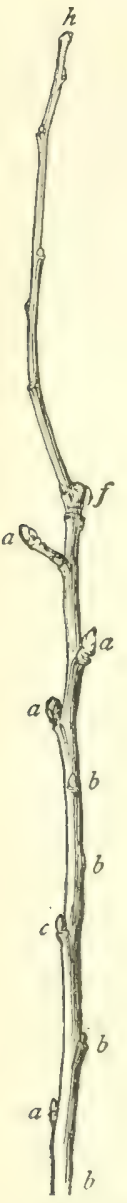

FIG. 155.-AN APPle TWig.

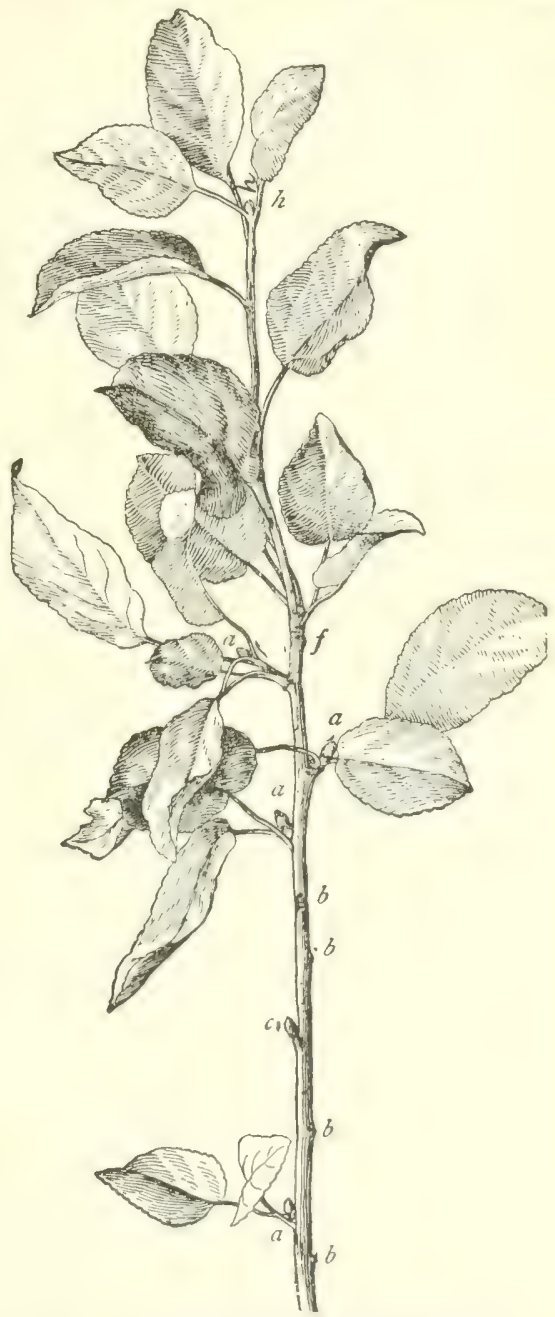

Fig. 156.- Same twig before leaves fel:

will never stand below it again. The twig, therefore, has buds of two ages, - those at $b b b b$ are two seasons old, and those on the 
tips, of all the branches (adaa, $h$ ), and in the axil of every leaf, are one season old. It is only the terminal buds that are not axillary. When the bud begins to grow and to put forth leaves, it gives rise to a branch, which, in its turn, hears buds. - It will now be interesting to determine why certain buds gave rise to branches and why others remained dormant. The strongest shoot or branch of the year is the terminal one $(f h)$. The next in strength is the uppermost lateral one, and the weakest shoot is at the base of the twig. The clormant buds are on the under side (for the twig grew in a horizontal position). All this suggests that those buds grew which had the best chance, - the most sunlight and room. There were too many buds for the space, and in the struggle for existence those that had the best opportunities male the largest growth. This struggle for existence began a year ago, however, when the buds on the shoot below $f$ were forming in the axils of the leaves, for the buls near the tip of the shoot grew larger and stronger than those near its base. The growth of one year, therefore, is very largely determined by the conditions under which the buds were formed the previous year. Other bud characters. 125. It is easy to see the swelling of the budr in a room in winter. Secure branches of trees and shrubs, two to three feet long, and stand them in vases or jars, as you would flowers. Renew the water frequently and cut off the lower ends of the shoots occasionally. In a week or two the buds will begin to swell. Of red maple, peach, apricot, and other very early-flowering things, flowers may be obtained in ten to twenty days. 126. The shape, size, and colour of the winter buts are different in every kind of plant. By the buds alone botanists are often able to distinguish the kinds of plants. Even such similar plants as the different kinds of willows have good bud characters. 127. Distinguish and draw fruit-buds of apple, pear, peach, plum, and other trees. If different kinds of maples grow in the vicinity, secure twigs of the red or swamp maple, and the soft or silver maple, and compare the buds with those of the sugar maple and the Norway maple. What do you learn?

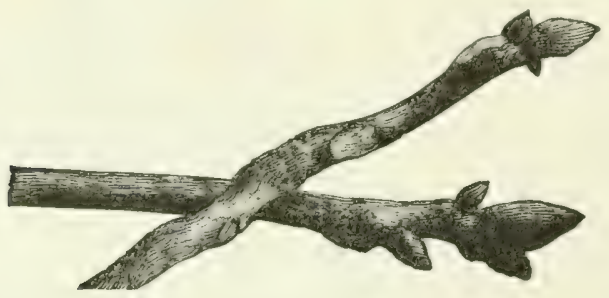

FIG. 157.-BUDS OF THE HICKORY. 


\section{CHAPTER XVI}

\section{BUD PROPAGATION}

WE have learned (in Chap. VI) that plants propagate by means of seeds. They also propagate by mans of bud parts, - as rootstocks (rhizomes), roots, muncrs, layers, bullis. The pupil should determine how any plant in which he is interested naturally propagates itself (or spreads its kind). Determine this for raspberry, blackberry, strawberry, Juneorass or other grass, nut-grass, water lily, May apple or mandrake, burdock, Irish potato, sweet potato, buckwheat, cotton, pea, corn, sugar-cane, wheat, rice.

Plants may be artificially propagated by similar means, as by layers, cuttings, and grafts. The last two we may discuss here.

Cuttings in General. - $A$ bit of a plant stuck into the ground stands a chance of growing; and this bit is a cutting. Plants have preferences, however, as to the kind of bit which shall be used, but there is no way of telling what this preforence is crecpt by trying. In some instances this preference has not been discovered, and we say that the plant cannot be propagated by cuttings.

Most plants prefer that the cutting be made of the soft or growing parts (called "wood" by gardeners), of which the "slips" of geranium and coleus are examples. Others grow equally well from cuttings of the hard or mature parts or wood, as currant and grape; and in some instances this mature wood may be of roots, as in the blackberry. In some cases cuttings are made of tubers, as in the Irish 
potato (Fiv. 60). P'upils should make cuttings now and then. If they can do nothing more, they can make cut. tings of potato, as the farmer does; and they can plant them in a box in the window.

The Softwood Cutting. - The softwood cutting is made from tissue that is still growing, or at least from that which is not dormant. It compriscs one or two joints, with

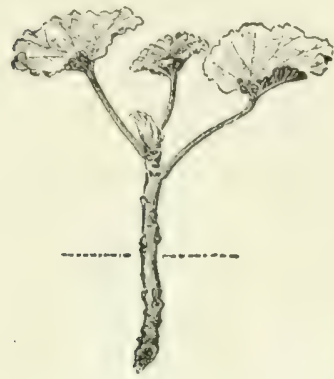

Fig. 158. - GiR $\wedge$ NiUM CUTTING.

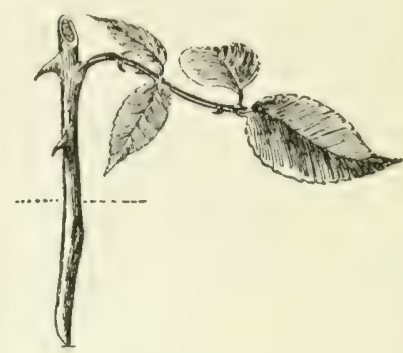

Fig. I59. - Rose CUtTing.

a leaf attached (Figs. I 58, I 59). It must not be allowed to wilt. Therefore, it must be protected from divect sunlight and diy air until it is acell established; and if it has many leares, some of them should be romored, or at least cut in two, in ordir to reduce the earporating surface. The soil should be uniformly moist. The pictures show the depth to which the cuttings are planted.

For most plants, the proper age or maturity of wood for the making of cuttings may be determined by giving the twig a quick bcnd: if it snaps and hangs by the bark, it is in proper condition; if it bonds withont breaking, it is too young and soft or too old; if it splinters, it is too old and woody'. The tips of strong upright shoots usually make the best cuttings. Preferably, each cutting should have a joint or node near its base; and if the internodes are very short it may comprise two or three joints. 
The stem of the entting is inserted one thith or more of its lingth in clean sand or graid, and the iarth is pressed fimly about it. A newspaper may be laid ower the bed to exclude the light - if the sun strikes it - and to prevent too rapid evaporation. The soil should be moist clear through, not on top only.

Loose sandy or graiclly soil is uscd. Sand used by masons is good material in which to start most cuttings; or fine gravel-sifted of most of its earthy matter-may be used. Soils are avoided which contain much decaying organic matter, for these soils are breeding places of fungi, which attack the soft cutting and cause it to "damp

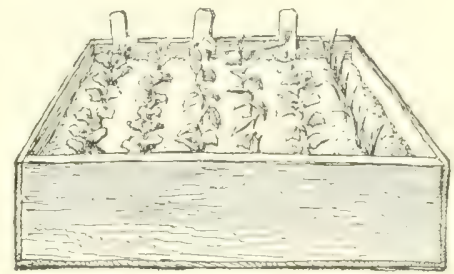

Fig, 160.-CuTtING-BO.: off," or to die at or near the surface of the ground. If the cuttings are to be grown in a window, put three or four inches of the earth in a shallow box or a pan. A soap? box cut in two lengthwise, so that it makes a box four or five inches deep - as a gardener's flat - is excellent (Fig. I60). Cuttings of common plants, as geranium, coleus,

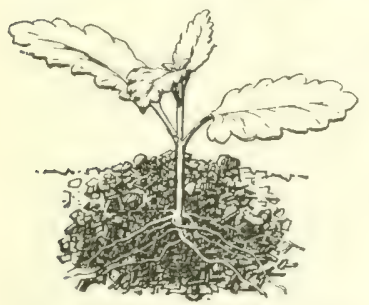

Fig. 16I. - Verbena Cuttingr READY FOR TRANSPLANTING. fuchsia, carnation, are kept at a living-room temperature. As long as the cuttings look bright and green, they are in good condition. It may be a month before roots form. When roots have formed, the plants begin to make new leaves at the tip. Then they may be transplanted into other boxes or into pots. The verbena in Fig. I6I is just ready for cransplanting. 


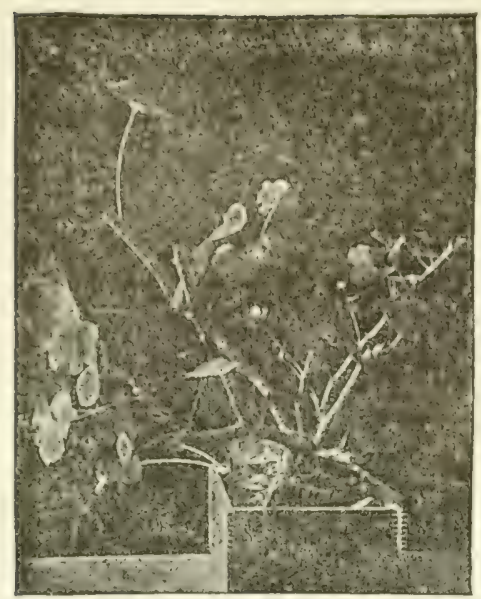

Fig. I62. - Old Geranium Plant CUT BACK TO MAKE IT THROIV OUT SHOOTS FROM WHCH CUTINGS CAN BE MADE.
It is not always casy to find growing shoots from which to make the cuttings. The best practice, in that case, is to cut back an old plant, then kecp it wame and woll watcred, and thercby force it to throw out ncru shoots. The old geranium plant from the window garden, or the one taken up from the lawn bed, may be treated this way (sec Fig. 162). The best plants of gुeranium and coleus and most window plants are those which are not more than one year old. The gcranium and fuchisia cuttings auhich are made in Jamuary, February, or March will give compact blooming plants for the next winter; and thercafter new ones should take their places (Fig. I63).

\section{The Hardwood} Cutting. - Best results with cuttings of mature wood are

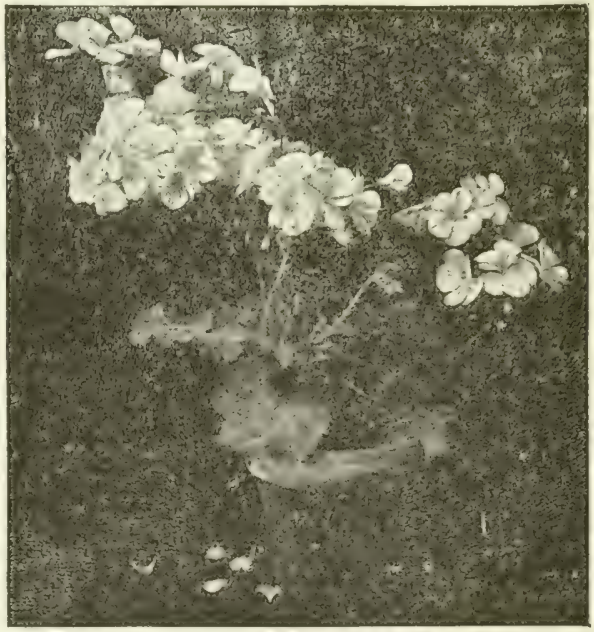

Fig. r63. - EARLy Winter Geranium, from a spring cutting. 
secured wethen the cutings are made in the firll and then buricd until spring in sand in the collor. These cuttings are usually six to ten inches long. They are not idle while they rest. The lower end calluses or heals, and the roots form more readily when the cutting is planted in the spring. But if the proper season has passed, take cuttings at any time in winter, plant them in a deep box in the window, and watch. They will need no shading or special care. Grape, currant, gooseberry, willow, and poplar readily take root from the hardwood. Fig. 164 shows a currant cutting. It has only one bud above the ground.

The Graft. - When the cutting is inserted in a plant rather than in the soil, it is a graft; and the graft may grow. In this case the cutting grows fast to the other plant, and the two become one. When the cutting is inserted in a plant, it is no longer called a cutting but a scion; and the plant in which it is inserted is called the stock. Fruit trees are grafted in order that a cortain varicty or kind may be perpetuated, as a Baldwin or Ben Davis variety of apple, Seckel or Bartlett pear, Navel

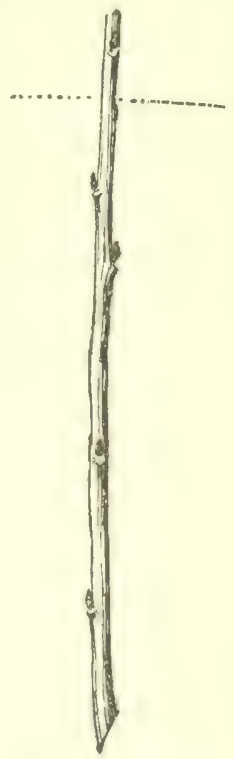
FIG. I64.- CuRRANT CUTIING. or St. Michael orange.

Plants have preferences as to the stecks on which they will growe; but we can find ont what their choice is only by making the cxpriment. The pear grows well on the quince, but the quince does not thrive on the pear. The pear grows on some of the hawthorns, but it is an unwilling subject on the apple. Tomato plants will grow on potato plants and potato plants on tomato plants. 
When the potato is the root, both fomatoes and potatoes may be produced, although the crop will be very small; when the tomato is the root, neither potatoes nor tomatoes will be produced. Chestnut will grow on some kinds of oak. In general, one species or kind is grafted on the same species, as apple on apple, pear on pear, orange on orange.

The forming, grouing tissue of the stcm (on the plants we have been discussing) is the cambium (Chap. X), lying on the ontside of the woody cylinder boneath the bark. In verter that union may take place, the cambium of the scion and of the storti imust come torgether. Therefore the scion is set in the side of the stock. There are many ways of shaping the scion and of preparing the stock to receive it. These wars are dictated largely hy the relative sizes of scion and stork, although many of them are matters of personal preference. The underlying principles are two: securing clese contact between the cambiums of scion and stock; colering the loumded surfaces to prevent evaporation and to protect the parts from disease.

On large stocks the commonest form of grafting is the cleft-graft. The stock is eut off and split; and in one or hoth sides a wedge-waped s.ion is firmly inserted. Fig. 16.) shows the suion; Fig. 166, the scions set in the stock; Fig. 167, the stock waxed. It will be seen that the lower bud-that lying in the wedge-is covered by the wax; but being nearest the food supply and least exposed to weather, it is the most likely to grow: it will push through the wax.

Cleft-grafting is practised in spring, as grouth begins. The scions are cut previousty, when perfectly dormant, and from the tree uhich it is desired to propagate. The scions are kept in sand or moss in the cellar. Limbs of various 
sizes may be cleft-grafted,-from a half inch up to fom inches in diameter; but a diameter of one to one and a half inches is the most convenient size. All the leading or main branches of a tree top may be grafted. If the remaining parts of the top are gradually cut away and the scions grow well, the entire top will be changed over to the new variety.

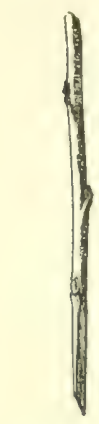

FIG. I65.-

SCION OF APPlif.

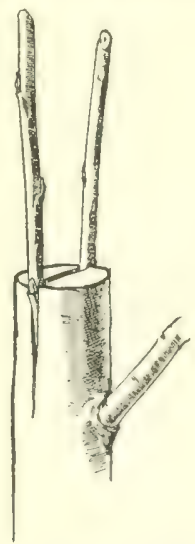

FIG. I66,-THE

SCION INSERTED.

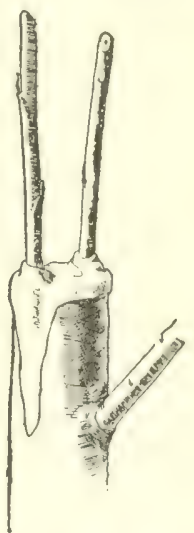

FIG. I67.-THE PARTS WAXED.

Another form of grafting is known as budding. In this case a single bud is used, and it is slipped underneath the bark of the stock and securely tied (not waxed) with soft material, as bass bark, corn shuck, yarn, or raffia (the last a commercial palm fihre). Budding is performed when the bark of the stock will slip or ped (so that the bud can be inserted), and whin the bud is mature cnough to growe. Usually budding is performed in late summer or early fall, when the winter buds are well formed; or it may be practised in spring with huds eut in winter. In ordinary summer huching (which is the usual mode) the "bud" or" scion forms a union with the stork, and then lies dormant till the following spring, as if it were still on its own twig. 
Budding is mostly restricted to young trees in the nursery. In the spring following the budding, the stock is cut off just above the bud, so that only the shoot from the bud grows to make the future tree. This prevaling form of
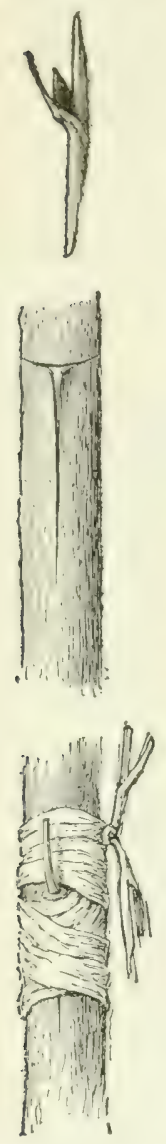

FIc. 168. - BuDDING, The "bud"; the opening to receive it; the bud tied. budding (shickd-budding) is shown in Fig. I68.

Suggestrons. - 128. Name the plants that the gardener propagates by means of cuttings. 129. By means of grafts. 130. The cutting-box may be set in the window. If the box does not receive direct sunlight, it may be covered with a pane of glass to prevent evaporation. Take care that the air is not kept too close, else the dampingoff fungi may attack the cuttings, and they will rot at the surface of the ground. See that the pane is raised a little at one end to afford ventilation; and if the water collects in drops on the under side of the glass, remove the pane for a time. 131. Grafting wax is made of beeswax, resin, and tallow. A good recipe is one part (as one pound) of rendered tallow, two parts of beeswax, four parts of resin; melt together in a kettle ; pour the liquid into a pail or tub of water to solidify it; work with the hands until it has the colour and "grain" of taffy candy, the hands being greased when necessary. The wax will keep any length of time. For the little grafting that any pupil would do, it is better to buy the wax of a seedsman. 132. Grafting is hardly to be recommended as a general school diversion, as the making of cuttings is; and the account of it in this chapter is inserted chiefly to satisfy the general curiosity on the subject. 133. In Chap. V we had a definition of a plant generation : what is "one generation" of a grafted fruit tree, as Le Conte pear, Baldwin, or Ben Davis apple? 134. The Elberta peach originated about I880: what is meant by "originated"? 135. How is the grape propagated so as to come true to name (explain what is meant by "coming true")? currant? strawberry? raspberry? blackberry? peach? pear? orange? fig? plum? cherry? apple? chestnut? pecan? 


\section{CHAPTER XVII}

\section{HOW PLANTS CLIMB}

WE have found that plants struggle or contend for a place in which to live. Some of them become adapted to grow in the forest shade, others to grow on other plants, as epiphytes, others to climb to the light. Observe how woods grapes, and other forest climbers, spread their foliage on the very top of the forest tree, while their lons flexile trunks may be bare.

There are several ways by which plants climb, but most climbers may be classified into four groups: ( I scramblers, (2) root climbers, (3) tendril climbers, (4) twiners.

Scramblers. - Some plants rise to light and air by resting thir long and weak stoms on the tops of bushes and quick-growing herts. Their stems may be eievated in part by the growing twigs of the plants on which they recline. Such plants are scramblers. Usually they are provided with prickles or bristles. In most weedy swamp thickets, scrambling plants may be found. Bricrs, some roses, bedstraw or galium, bittersweet (Solamum Dulcamara, not the Celastrus), the tear-thumb polygonums, and other plants are familiar examples of scramblers.

Root Climbers. - Some plants climb by means of tme roots. These roots seek the dark places and therefore enter the chinks in walls and bark. The trumpet creeper is a familiar example (Fig. 36). The true or English ivy, which is often grown to cover buildings, is another instance. Still another is the poison ivy. Roots are 
distinguished from stem tendrils by their inrgular on indifinite fosition as well as by their mode of growth.

Tendril climbers. - A slender coiling part that serves to hold a climbing plant to a support is known as a tendril.

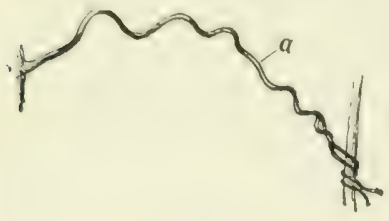

Fic. 169. - TENDRIT, to show where the coil is changed.

The free end swings or curves until it strikes some object, when it attaches itself and then coils and draws the plant close to the support. The spring of the coil also allows the plant to more in the wind, thereby enabling the plant to maintain its hold. Slowly pull a well-matured tendril from its support, and note how strongly it holds ou. Watch the tendrils in a wind-storm. Usually the tendril attaches to the support hy coiling about it, but the Virginia ereeper and the Boston ivy (Fig. 170) attach to walls by means of disks on the ends of the tendrils.

Since both ends of the tendril are fixed, when it finds a support, the coiling would tend to twist it in two. It will be found, however, that the tendril coils in different di-

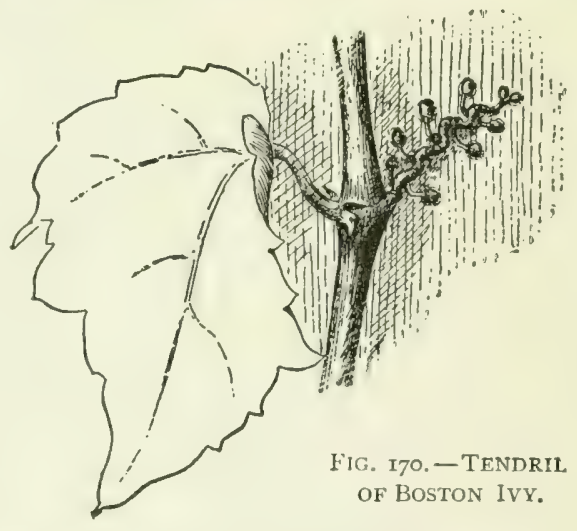
rections in different parts of its length. In Fig. I69, showing an old and stretched-out tendril, the change of direction in the coil occurred at $a$. In long tendrils of cucumbers and melons there may be several changes of direction.

Tendrils may represent either branches or lcaies. In the 
Virginia creeper and the grape they are hranches; they stand opposite the leaves in the position of fruit chusters, and sometimes one hranch of a fruit duster is a tendril. These tendrils are therefore homologoms with fruit-rlusters. and fruit clusters are branches.

In some plants tendrils are leaflets (Chap. XI). Examples are the sweet pea and the common garden pea. In Fig. I 7 , observe the leaf with its two great stipules, petiole, six normal leaflets, and two or three pairs of leaflet tendrils and a terminal leaflet tendril. The cobea, a common garden climber, has a similar arrangement. In some cases tendrils are stipules, as probably in the green briers (smilax).

The patiole or midrib may act as a tcndril, as in various kinds of clematis. In Fig. I72, the common wild clematis or "old man vine," this mode is seen.

Twiners. - The entire

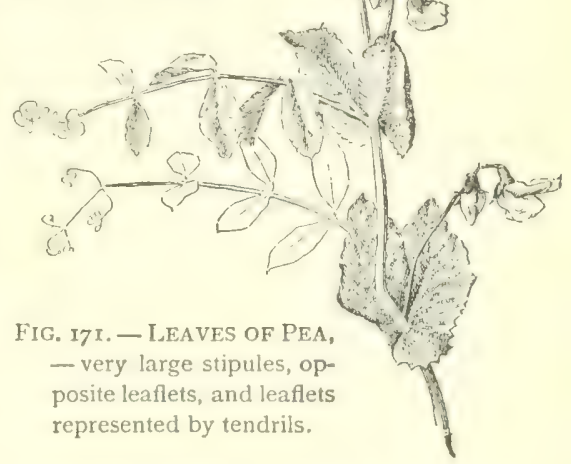
plant or shoot may wind about a support. Such a plant is a twiner. Examples are bean, hop, morning-glory, moonflower, false bittersweet or waxwork (Cclerstms), some honeysuckles, wistaria, Dutchman's pipe, dodder. The free tip of the twining branch saips about in curacs, much as the tendril does, until it finds support or becomes old and rigid.

Each kind of plant usually coils in only one dircction. Most plants coil asainst the sun, or from the observer's left across his front to his right as he faces the plant. 
Examples are bean, morning-glory. The hop twines from the observer's right to his $A$ left, or with the sun.

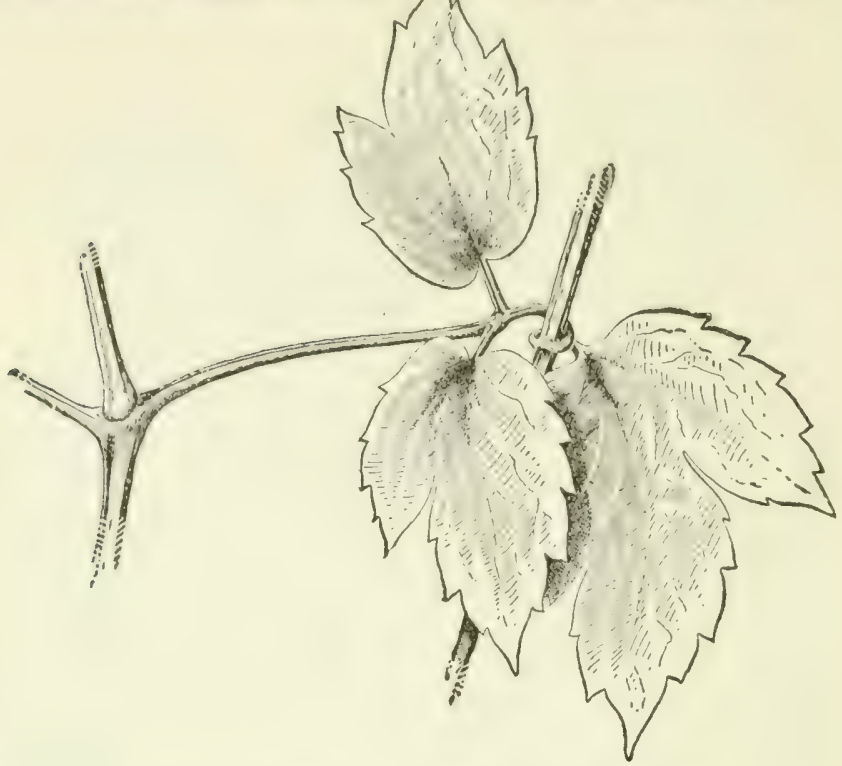

FIG, I72. - CLEMATIS CLIMBING BY LEAF-TENDRIL.

Stgaestioxs.-136. Set the pupil to watch the behaviour of any plant that has temirils at different stage's of maturity. A rigorous ("urumber Ilant is one of the best. Just beyoul the point of a young straight tendril set a stake to compare the position of it. Note whether the tendril changes position from hour to hour or day to das. 137. Is the tip of the tendril perfectly straight? Why? Fet a small stake at the enel of a strong straight temiril, so that the tendril will just reach it. Watch and make drawing. 138. If a tendril does not find a support what does it do? 139. To test the morement of a free tendril draw an ink line lengthwise of it, and note whether the line remains always on the coneave side or the convex sile. 140. Name the tenilril-bearing plants that you know. 141. Trake similar observations and experiments on the tips of twining stems. 142. What twining plants lo you know, and which way do they twine? 143. How does any plant that you know shoot up? 144. Does the stem of a climbing plant contain more or less substance (weight) than an crect sclf-supporting stem of the same height? Explain. 


\section{CHAPTER XVIII}

\section{THE FLOWER - ITS PARTS AND FORMS}

THE function of the flower is to produce sed. It is proballe that all its varied forms and colours rontribute to this supreme end. These forms and colour's please the human fancy and add to the joy of living, but the flower exists for the good of the plant, not for the good of man. The parts of the flower are of two general kinds - those that are directly concerned in the production of sects, and those that act as coicring and protecting organs. The former parts are known as the essential organs; the latter as the floral envelopes.

Envelopes. - The floral envelopes usually bear a close resemblance to leaves. These envelupes are very commonly of two series or kinds - the outer and the inner. The outer series, known as the calyx, is usually smaller and green. It usually comprises the outer cover of the flower bud. The calyx is the lowest whorl in Fig. I73.

The inner series, known as the corolla, is usually coloured and more

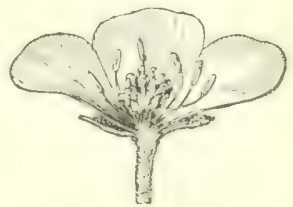

FIG. 173. - FLOWER OF A BUTTERCUP IN SECTION.

special or irregular in shape than the calyx. It is the showy part of the flower, as a rule. The corolla is the second or large whorl in Fig. I73.

The calyx may be composed of several leaves. Each leaf is a sepal. If it is of one piece, it may be lobed or divided, in which case the divisions are called calyx-lobes. 
In like manner, the corolla may be composed of petals, or it maty be of one piece and rariously lobed. A calyx of one piece, no matter how deeply lobed, is gamosepalous. $A$ corollit of one piece is gamopetalous. When these series are of separate pieces, as in Iig. I 73, the flower is said to be polysepalous and polypetalous. Sometimes both

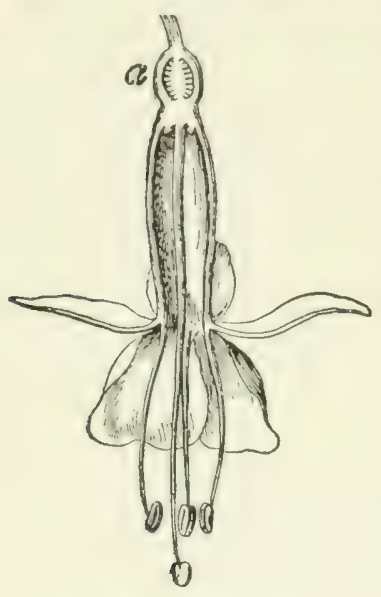

FIG. 174. - FIOUIER OF FUCHSIA IN SECTION. series are of separate parts, and sometimes only one of them is so formed.

The floral envelopes are homologons with leaves. Sepals and petals, at least when more than three or five, are in more than one whorl, and one whorl stands below another so that the parts overlap. They are borne on the expanded or thickened end of the flower stalk; this end is the torus. In Fig. I 73 all the parts are seen as attached to the torus. This part is sometimes called the recoptacli, but this word is a common-language term of several meanings, whereas torus has no other meaning. Sometimes one part is attached to another part, as in the fuchsia (Fig. I74), in which the petals are borne on the calyx-tulse.

Subtending Parts. - Sometimes there are lcaf-like parts just bclow the caly'x, looking like a second calyx. Such parts accompany the carnation flower. These parts are bracts (bracts are small specialized leaves); and they form an involucre. We must be careful that we do not mistake them for true flower parts. Sometimes the bracts are large and petal-like, as in the great white blooms of the 
flowering dogwood: here the real flowers are several, small and greenish, forming a small ruster in the rentre.

Essential Organs. - The essential organs are of two series. The outer series is composed of the stamens. The inner series is composed of the pistils.

Stamens bear the pollen, which is made up of grains or spores, each spore usually being a single plant cell. The stamen is of two parts, as is readily seen in Figs. I73, I74, - the enlarged terminal part or anther, and the stalk or filament. The filament is often so short as to seem to be absent, and the anther is then said to be sessile. The anther bears the pollen spores. It is made up of two or four parts (known as sporangia or spore-cases), which burst and discharge the pollen. When the pollen is shed, the stamen dies.

The pistil has three parts: the lowest, or seedbearing part, which is the ovary; the stigma at the upper extremity, which is a flattened or expanded surface, and usually roughtened or sticky; the stalklike part or style, “ommerting the ovary and the stig-

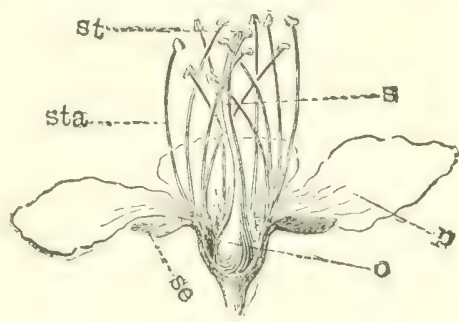

Fig. 175. - THE STRUCTURE OF $\boldsymbol{\Lambda}$ Plum Blossom.

se, sepals; p. petals; stu, stameus; o, ovary; $s$, style; st, tigma. The pistil consists of the ovary, the style and the stigma. It contains the seed part. The stan:ens are tipped with anthers, in which the pollen is borne. The ovary, 0 , ripens into the fruit. ma. Sometimes the style is apparently wanting, and the stigma is said to he sessile on the ovary. These parts are shown in the furhsia. (Fig. 174). The ovary or seed vessel is at $a$. A long style, hearing a large stigma, projerets from the flower. See also Figs. 175 and 176.

Stamens and pistils probably are homologous with leaves. A pistil is sometimes conceived to represent anciently a 
leaf as if rolled into a tube; and an anther, a leaf of which the edges may have been turned in on the midrib.

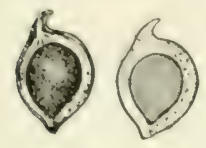

FIG. I76. - SIMPLE PIsTils of BUTTERCUP, one in longitudinal section.

The pistil may be of one part or compartment, or of many parts. The different units or parts of which it is composed are carpels. Each carpel is homologous with a leaf. Each carpel bears one or more seeds. A pistil of one carpel is simple; of two or more carpels, compound. Usually the structure of the pistil may be determined by cutting horizontally across the lower or seedbearing part, as Figs. I77, I78 explain. A flower may contain a simple pistil (one carpel), as the pea (Fig. I77); several simple pistils (several separate carpels), as the buttercup (Fig. I76); or a compound pistil with carpels united, as the Saint John's wort (Fig. I 78) and apple. How many carpels in an apple? A peach? An okra pod? A bean pod? The seed cavity in each carpel is called a locule (Latin locus, a place). In these locules the seeds are bome.

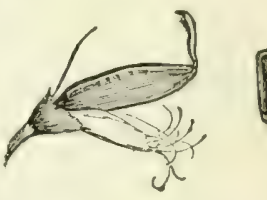

FIG. 177. - PISTIL OF Garden PEA, the stamens being pulled down in order to disclose it; also a section showing the single compartment (compare Fig. 188).

Conformation of the Flower. - A

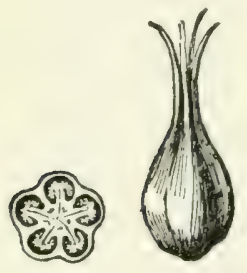

F1G. I78. - COMPOUND PISTIL OF A ST. JOHN's WORT. It has 5 carpels. flower that has calyx, corolla, stamens, and pistils is said to be complete (Fig. 173); all others are incomplete. In some flowers both the floral envelopes are wanting: such are naked. When one of the floral envelope series is wanting, the remaining series is said to be calyx, and the flower is therefore apetalous (without petals). The knot- 


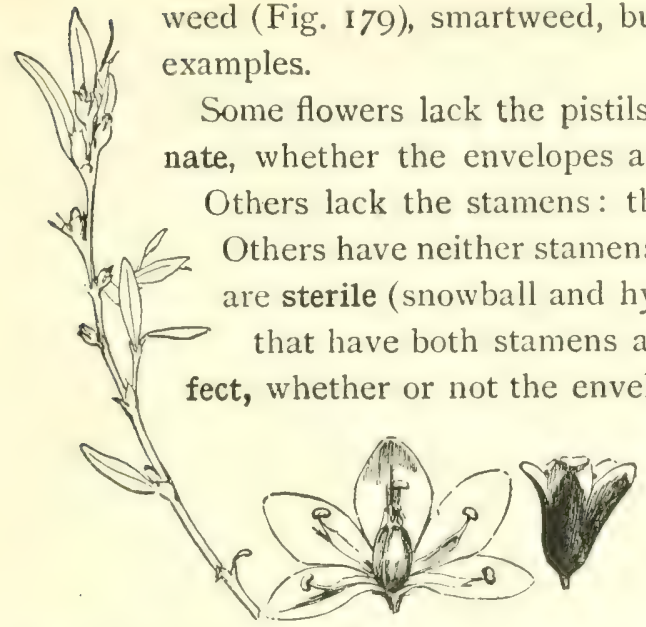

FIG, 179. - KNOTWEED, a very common but inconspicuous plant along hard walks and roads. 'Two flowers, enlarged, are shown at the right. These flowers are very small and borne in the axils of the leaves.
Those that lack eitherstamens or pistils are imperfect or diclinous. Staminate and pistillate flowers are imperfect or diclinous.

When staminate and pistillate flowers are borne on the same plant, e.g. oak (Fig. I80), corn, beech, chestnut, hazel, walnut, hickory, pine, begonia (Fig. I8I), watermelon,

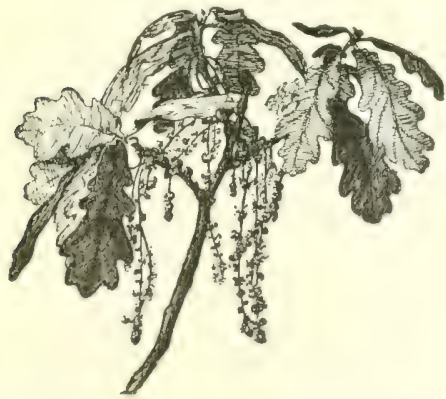

Fig, I80, - Staminate Cathins of OAK. The pistillate flowers are in the leaf axils, and not shown in this picture.

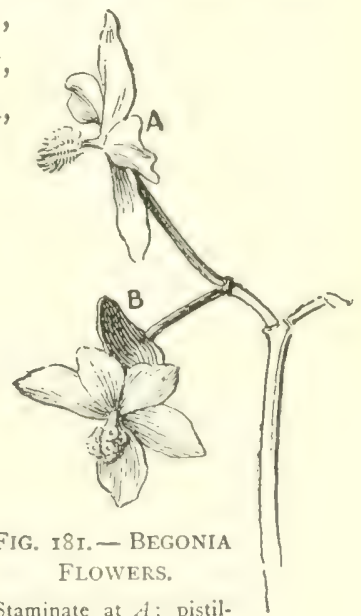

Staminate at $A$ : pistillate below, with the winged ovary at $B$. 
gourd, pumpkin, the plant is monæcious ("in one house"). When they are on different plants, $c \cdot s$. poplar, cottonwood,

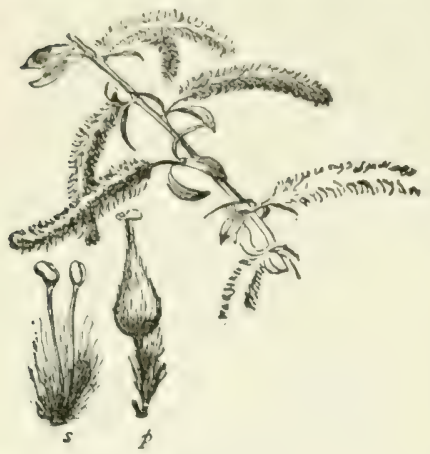

Fig. I82. - Catkins of A Willow.

A staminate flower is shown at $s$, and a pistillate flower at $p$. The staminate and pistillate are on different plants.

bois d'arc, willow (Fig. 182), the plant is diœcious (" in two houses"). Some varieties of strawberry, grape, and mulberry are partly diøcious. Is the rose either monøecious or diøcious?

Flowers in which the parts of each series are alike are said to be regular (as in Figs. I73, I74, 175). Those in which some parts are unlike other parts of the same series are irregular. Their regularity may be in calyx, as in nasturtium (Fig. I83); in corolla (Figs. I84, I85); in the

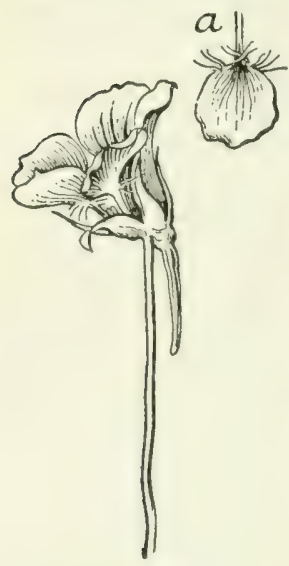

FIG. 183. - FLOWER OF Garden Nasturtium.

Separate petal at $a$. The calyx is produced into a spur. stamens (compare nasturtium, catnip, Fig. I 85 , sage); in the pistils. Irregularity is most frequent in the corolla.

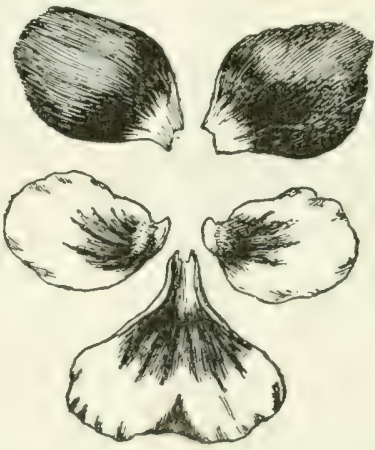

Fig. 184. - The Five Petals OF THE PANSY, detached to show the form.

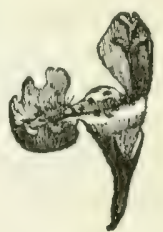

FIG. 185. FLOWER OF CatNiP. 
Various Forms of Corolla. - The corolla often assumes very definite or distinct forms, especially when gamopetalous. It may have a long tube with a wide-flaring limb, when it is said to be funnelform, as in morning and pumpkin. If the tube is very narrow and the limb stands at right angles to it, the corolla is salverform, as in phlox. If the tube is very short and the limb widespreading and nearly circular in outline, the corolla is rotate or wheel-shaped, as in potato.

A gamopetalous corolla or gamosepalous calyx is often cleft in such way as to make two prominent parts. Such parts are said to be lipped or labiate. Each of the lips or lobes may be notched or toothed. In 5 -membered flowers, the lower lip is usually 3 -lobed and the upper one 2-lobed. Labiate flowers are characteristic of the mint family (Fig. 185), and the family therefore is called the Labiatre. (Literally, labiate means merely "lipped," without specifying the number of lips or lobes; but it is commonly used to desig. nate 2-lipped flowers.) Strongly 2-parted polypetalous flowers may be said to be labiate; but the term is oftenest used for gamopetalous corollas.

Labiate gamopetalous flowers that are closed in the throat (or entrance to the tube) are said to be grinning or personate (personate means masticd). Snapdragon is a typical example;

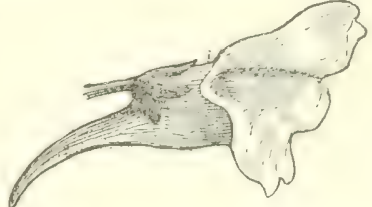

FIG. I86.-- PERSONATE FIuWER OF TOADFLAX. also toadflax or butter-ant-egges (Fig. 196), and many related plants. Personate flower's usually have definite relations to insect pollination. Ohserve how an insect fores his head into the elosed throat of the toatfiax. 
The peculiar flowers of the pea tribes are explained in Figs. I 87, I 88 .

Spathe Flowers. - In many plants, very simple (often naked) flowers are borne in dense, more or less fleshy spikes, and the spike is inclosed in or attended by a leaf, sometimes corolla-like, known as a spathe. The spike of flowers is technically known as a spadix. This type of flower is characteristic of the great arum family, which is

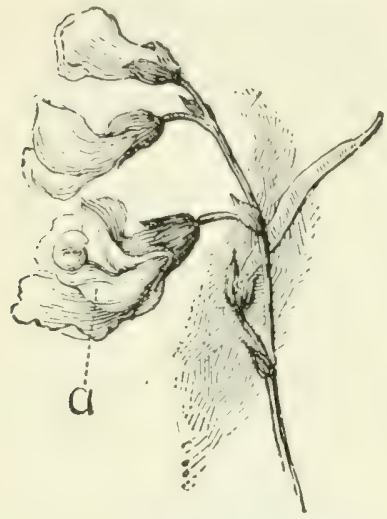

FIG. I87.-FLOWERS OF THE

CoMmon BEAN, with one flower opened (a) ro show the structure.

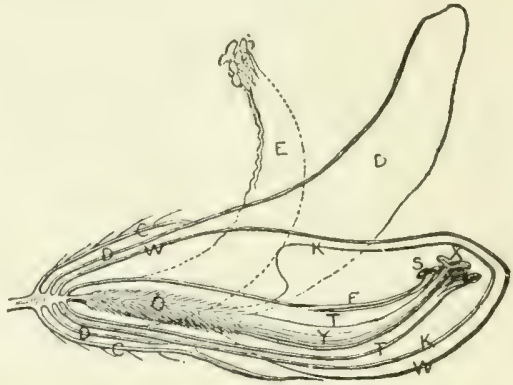

Fig. 188. - DiAgRaM OF AlFalfa Flower IN SECTION :

$C$, calyx, $D$, standard; $W$, wing: $K$, keel; $T$, stamen-tube; $F$, filament of tenth stamen; $X$, stigma; $Y$, style: $O$, ovary; the dotted lines at $E$ show position of stamen tube, when pushed upward by insects. Enlarged.

rhiefly tropical. The commonest wild representatives are . Jack-in-the-pulpit, or Indian turnip, and skunk cabbage. In the former the flowers are all diclinous and naked. In the skunk cabbage all the flowers are perfect and have four" sepals. The common calla is a good example of this type of inflorescence.

Composite Flowers.-The head (anthodium) or socalled "flower" of sunflower (Fig. I89), thistle, aster, dandelion, daisy, chrysanthemum, goldenrod, is composed of scucral or many little flowers, or florets. These 
florets are inclosed in a more or less dense and usually green involucre. In the thistle (Fig. 190) this involucre is prickly. A longitudinal section discloses the florets, all attached at bottom to a common torus, and densely packed in the involucre. The pink tips of these florets constitute the showy part of the head.

Each floret of the thistle (Fig. I90) is a com-

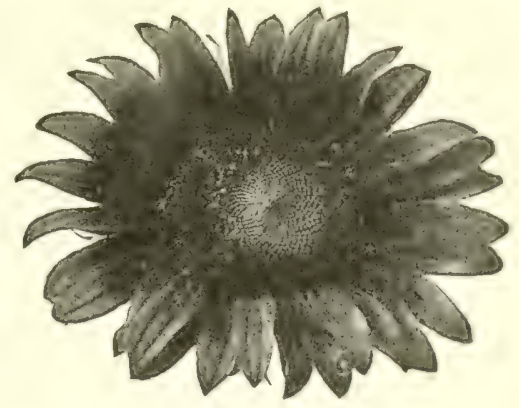

FiG. 189. - HEAD OF SUNFLOWER. plete flower. At $a$ is the ovary. At $b$ is a much-divided plumy calyx, known as the pappus. The corolla is longtubed, rising above the pappus, and is enlarged and 5-lobed
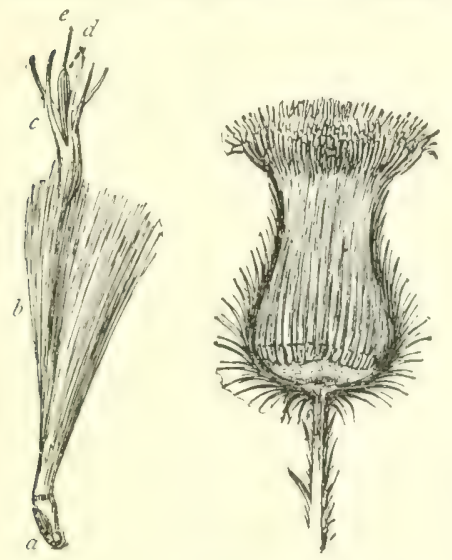

Fig. I90. - Longitudinal, Sri rion OF TUISTLE HEAD; also a FLoRET OF THISTLE. at the top, $c$. The style projects at $e$. The five anthers are united about the style in a ring at $d$. Such anthers are said to be syngenesious. These are the various parts of the florets of the Compositx. In some cases the pappus is in the form of barbs, bristles, or scales, and sometimes it is wanting. The pappus, as we shall see later, assists in distributing the seed. Often the florets are not all alike. The corolla of those in the outer circles may be developed into a long, straplike, or tubular part, and the head then has the ap- 
pearance of being one flower with a border of petals. Of such is the sunflower (Fig. ISo), aster, bachelor's button or comflower, and fickd daisy (lig. 2 I I). These long corollalimbs are called rays. In some cultivated composites, all the flopets may develop rags, as in the dahlia and the ehry-

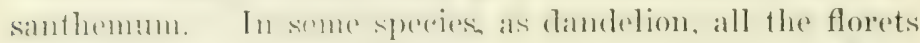
naturally have rays. Syngenesious arangement of anthers is the most characteristic single feature of the composites.

Double Flowers. - Under the stimulus of cultivation and increased food supply, flowers tend to become double.

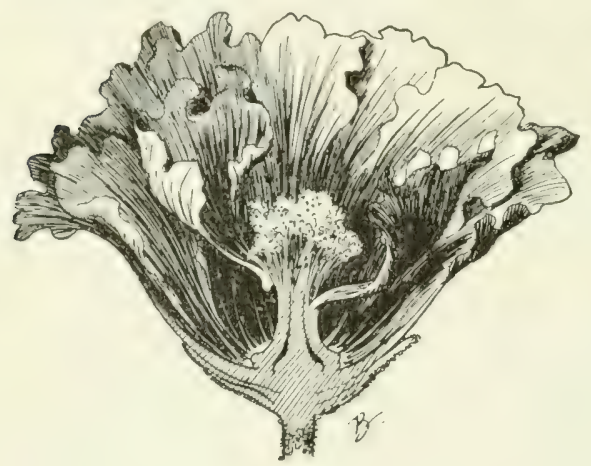

Fig, IOI.-PETALS ARISING FROM the STAMINAL COLUMN OF HOLLYHock, and accessory petals in the corolla-whorl.
True doubling arises in two ways, morphologically: (I)stamens or pistils may produce petals (Fig. I9I); (2) adventitious or accessory petals may arise in the circle of petals. Both these categories may be present in the same flower. In the full double hollyhock the petals derived from the staminal column are shorter and make a rosette in the centre of the flower. In Fig. 192 is shown the doubling of a daffodil by the modification of stamens. Other modifications of flowers are sometimes known as doubling. For example, double dahlias, chrysanthemums, and sunflowers are forms in which the disk flowers have developed rays. The snowball is another case. In the wild snowball the external flowers of the cluster are large and sterile. In the culti- 
vated plant all the flowers have become large and sterile. Hydrangea is a similar case.

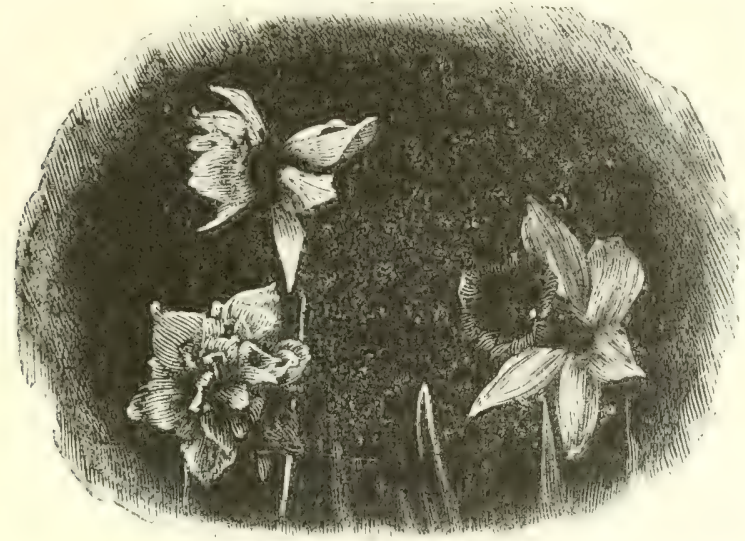

FIG. I92, - NARCISSUS OR DAFFODIL. Single flower at the right.

SugGestions. - 145. If the pupil has been skilfully couducted through this chapter by means of careful study of specimens rather than as a mere memorizing process, he will be in mood to challenge any flower that he sees and to make an effort to understand it. Flowers are endlessly modified in form; but they can be understood if the pupil looks first for the anthers and ovaries. How may anthers and ovaries always be distinguished? 146. It is excellent practice to find the flowers in plants that are commonly known by name, and to determine the main points in their structure. What are the flowers in Indian corn? pumpkin or squash? celery? cabbage? potato? pea? tomato? okra? cotton? rhubarb? chestnut? wheat? oats? 147. Do all forest trees have flowers? Explain. 148. Name all the monoecious plants you know. Dicecious. 149. What plants do you know that bloom before the leaves appear? Do any bloom after the leaves fall? 150. Explain the flowers of marigold, hyacinth, lettuce, clover, asparagus, garden calla, aster, locust, onion, burdock, lily-of-the-valley, crocus, Golden Glow, rudbeckia, cowpea. 151. Define a flower.

Note to the Teacher. - It cannot be urged too often that the specimens themselves be studied. If this chapter becomes a mere recitation on names and definitions, the exercise will be worse than useless. Properly taught by means of the flowers themselves, the names become merely incidental and a part of the pupil's language, and the subject has living interest. 


\section{CHAPTER XIX}

\section{THE FLOWER - FERTILIZATION AND POLLINATION}

Fertilization. - Sceds result from the union of two clements or parts. One of these elements is a cell-nucleus

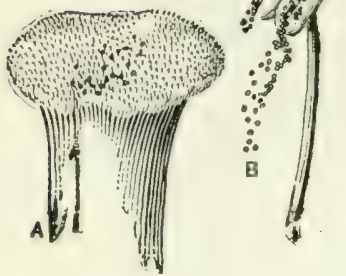

FIG. I93. $-B$, Pollen escap. ing from anther; $A$, pollen germinating on a stigma. Enlarged. of the pollen-grain. The other element is the cell-nucleus of an eggcell, borne in the ovary. The pollen-grain falls on the stigma (Fig. 193). It absorbs the juices exuded by the stigma, and grows by sending out a tube (Fig. 194). This tube grows downward through the style, absorbing food as it goes, and finally reaches the egg-cell in the interior of an ovule in the ovary (Fig. 195), and fertilization,

or union of a nucleus of the pollen and the nucleus of the egg-cell in the ovule, takes place. The ovnle and cmbryo within then develops into a sced. The growth of the pollen-tube is often spoken of as germination of the pollen, but it is not germination in the sense in which the word is used when speaking of seeds.

Better seeds - that is, those that produce stronger and more fruitful plants - often result when the pollen comes from another flower. Fertilization effected between different flowers is cross-fertilization; that resulting from the

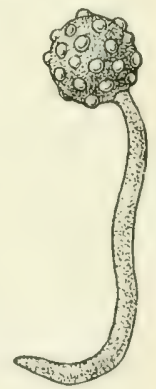

FIG. 194. A POLLENGRAIN AND THE GROW. ING TUBE. 
application of pollen to pistils in the same flower is closefertilization or self-fertilization. It will be seen that the cross-fertilization relationship may be of many degreesbetween two flowers in the same cluster, between those in different clusters on the same branch, between those on different plants. Usually fertilization takes place only between plants of the same species or kind.

In many cases there is, in effect, an apparent selection of pollen when pollen from two or more sources is applied to the stigma. Sometimes the foreign pollen, if from the same kind of plant, grows, and fertilization results, while pollen from the same flower is less promptly effective. If, however, no foreign pollen is present, the pollen from the same flower may finally serve the same purpose.

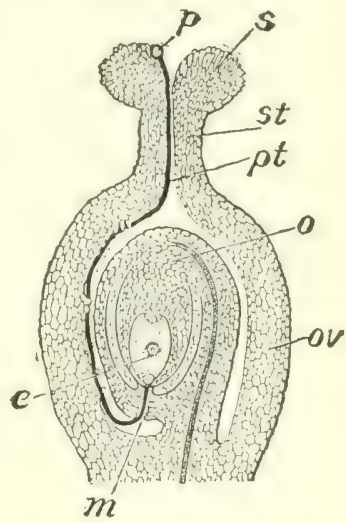

FIG. I95. - DiAgraM TO REPRESENT FERTILIZATION.

$s$, stigma; $s t$, style; or", ovary; o, ovule; $\phi$, pollen-grain; $\phi t$, pollen-tube; e, egg-cell; $m$, micropyle.

In order that the pollen may grow, the stigma must be ripe. At this stage the stigma is usually moist and sometimes sticky. A ripe stigma is said to be receptive. The stigma may remain receptive for several hours or even days, depending on the kind of plant, the weather, and how soon pollen is received. Watch a certain flower every day to see the anther locules open and the stigma ripen. When fertilization takes place, the stigma dies. Observe, also, how soon the petals wither after the stigma has received pollen.

Pollination. - The transfer of the pollen from anther to stigma is known as pollination. The pollen may 
fall of its own weight on the adjacent stigma, or it may be carried from flower to flower by wind, insects, or other agents. There may be self-pollination or cross-pollination, and of course it must always precede fertilization.

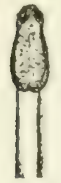

Fis. 196.ANTHER OF

AzIIIEA, opening by terminal pores.

Usually the pollen is discharged by the bursting of the anthers. The commonest method of discharge is through a slit on either side of the anther (Fig. 193). Sometimes it discharges through a pore at the apex, as in azalea (Fig. ig6), rhododendron, huckleberry, wintergreen. In some plants a part of the anther wall raises or falls as a lid, as in barberry (Fig. I97), blue cohosh, May apple. The opening of an anther (as also of a sced-pod) is known as dehiscence ( $d c$, from; hisco, to gape). When an anther or seed pod opens, it is said to delisce.

Ilost flowers are so constructed as to increase the chances of cross-pollination. We have seen that the stigma may have the power of choosing foreign pollen. The commonest means of necessitating cross-pollination is the different times of maturing of stamens and pistils in the same flower. In most cases the stamens mature first: the flower is then proterandrous. When the pistils mature first, the flower is proterogynous. (Ancr, andr, is a Greek root often used, in combinations, for stamen, and syme for pistil.) The difference in time of ripening may be an hour or two, or it may be a clay. The ripening of the stamens

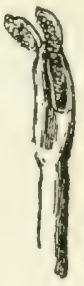

FIG. I97.BARBERRY STAMEN, with anther opening by lids. and the pistils at different times is known as dichogamy, and flowers of such character are said to be dichogamous. There is little chance for dichogamous flowers to pollinate themselves. Many flowers are imperfectly dichogamous - 
some of the anthers mature simultancously with the pistils, so that there is chance for self-pollination in case foreign pollen does not arrive. Even when the stigma receives pollen from its own flower, cross-fertilization may result. The hollyhock is proter. androus. Fig. I98 shows a

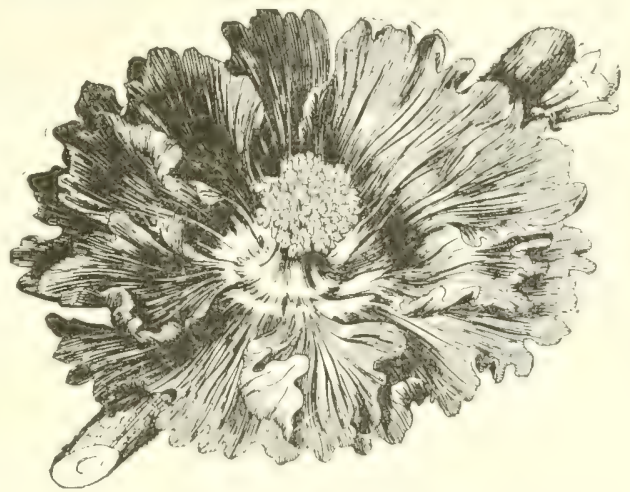
flower recently FIG. I98. - FlOWER OF HOLLYHOCK; proterandrous. expanded. The rentre is occupied by the column of stamens. In Fig. I99, showing an older flower, the long styles are conspicuous.

Some floaters are so constructed as to prohitit self-pollination. Very irregrular flowers are usually of this kind.

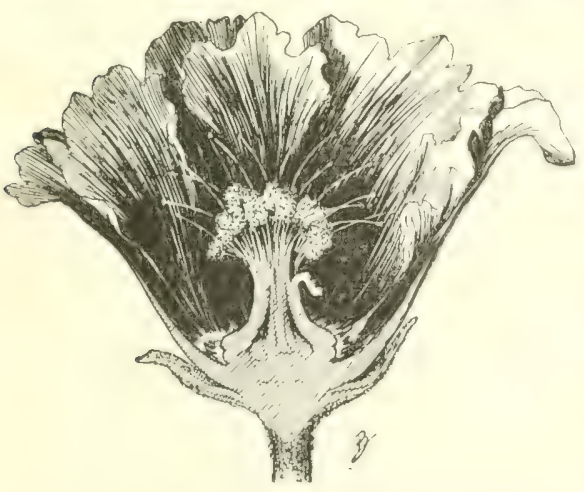

FIG. I99.- OLDER FLOWER OF HOLLYHOCK. With some of them, the petals form a. sac to inclose the anthers and the pollen cannot be shed on the stigma but is retained until a bee forces the sac open; the pollen is rubbed on the hairs of the bee and transported. Regular flowers usually depend mostly on dichorgamy and the selective power of the pistil to insure crossing flowers that are acry 
irregular and previded with necter and strong perfume are "lably pollinated by insects. Gaudy colomes probably alfract insects in many ases, hut perfume appears to be at

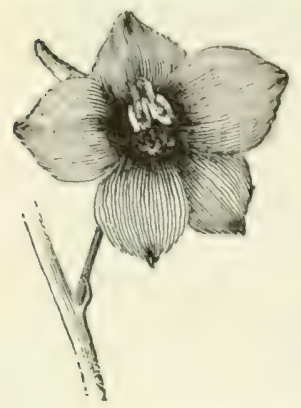

FIG. 200. - F1,OWER OF LAKKSPUK, greater attraction.

The insect visits the flower for the ncctar (for the making of honey) and may unknowingly camy the pollen. Spurs and sacs in the flower are nectaries (Fig. 200), but in spurless flowers the nectar is usually secreted in the bottom of the flower cup. This compels the insect to pass by the anther and rub against the pollen before it reaches the nectar. Sometimes the anther is a long lever poised on the middle point and the insect bumps against one end and lifts it, thus bringing the other end of the lever with the pollen sacs down on its back. Flowers that are pollinated by insects are said to be entomophilous (" insect loving”). Fig. 200 shows a larkspur. The envelopes are separated in Fig. 201. The long spur at once suggests insect pollination. The spur is a sepal. Two hollow petals project into this spur, apparently serving to guide the bee's tongue. The two smaller petals, in front, are peculiarly

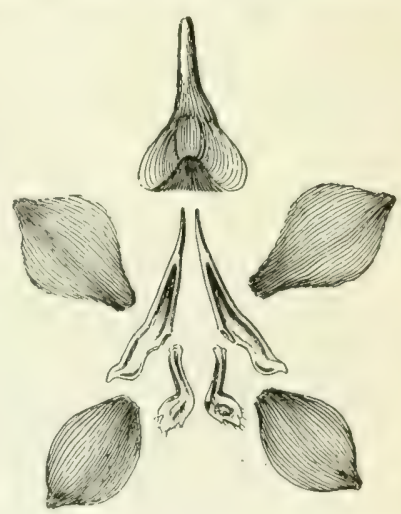

Fig. 201. - Envelopes of A LARKSPUR. There are five wide sepals, the upper one being spurred. There are four small petals. coloured and perhaps serve the bee in locating the nectary. The stamens ensheath the pistils (Fig. 202). As the insect stands on the flower and thrusts its head into the centre, 
the envelopes are pushed downward and outward and the pistil and stamens come in contact with its abdomen.

Since the flower is proterandrous, the pollen that the pistils receive from the bee's abdomen must come from another flower. Note a somewhat similar arrangement in the toadflax or butter-andeggs.

In some cases (Fig. 203) the stamens are longer than the pistil in one flower and shorter in another. If the insect visits such flowers, it gets pollen on its head from the long-stamen flower, and deposits this pollen on the stigma in the long-pistil flower. Such flowers are di-

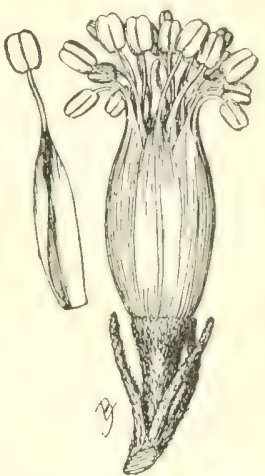

EIG, 202, - STAMENS OF LARKSPUR, surrounding the pistils. morphous (of two forms). If pollen from its own flower and from another flower both fall on the stigma, the probabilities are that the stigma will choose the foreign pollen.
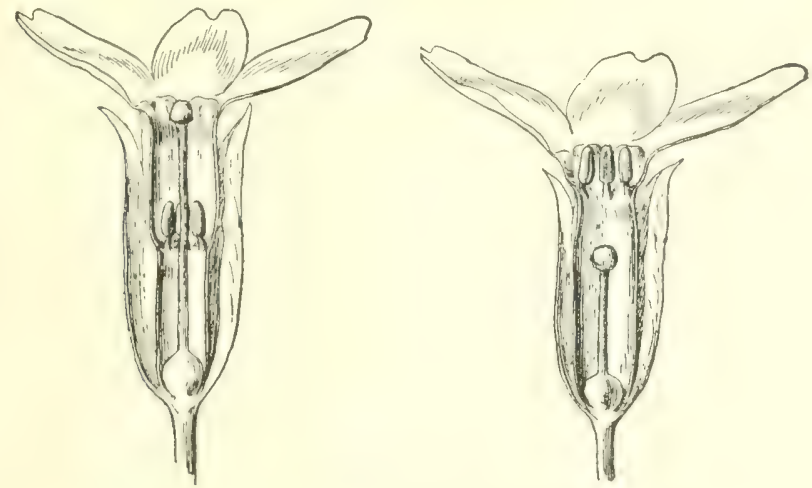

FIG. 203.- DIMORPHIC FLOWERS OF PRIMROSE.

Many flowers are pollinated by the wind. They are said to be anemophilous ("wind loving"). Such flowers pro- 
duce great quantities of pollen, for much of it is wasted. They usually have broad stigmas, which expose large surfaces to the wind. They are usually lacking in gaudy colours and in perfume. Grasses and pine trees are typiral cxamples of ancmophilous plants.

In many alses aross-pollination is assured herause the stamens and the pistils are in different flowers (dielinous).

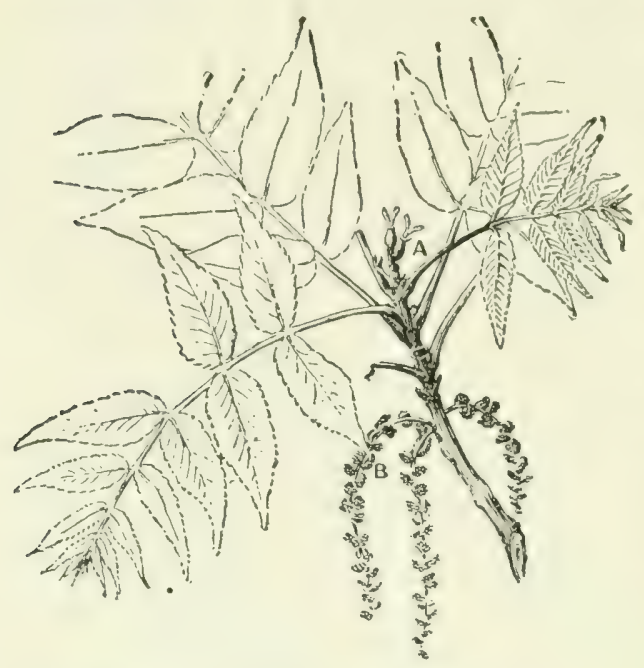

Fig. 204. - Flowers of BIACK IVALnUt: two pistillate flowers at $A$, and staminate catkins at $B$.

Monœecious and diœcious plants may be pollinated by wind or insects, or other agents (Fig. 204). They are usually wind - pollinated, although willows are often, if not mostly, insectpollinated. The Indian corn is a monœcious plant. The staminate flowers are in a terminal panicle (tassel). The pistillate flowers are in a dense spike (ear), inclosed in a sheath or husk. Each "silk" is a style. Each pistillate flower produces a kernel of corn. Sometimes a few pistillate flowers are borne in the tassel and a few staminate flowers on the tip of the ear. Is self-fertilization possible with the corn? Why does a "volunteer" stalk standing alone in a garden have only a few grains on the ear? What is the direction of the prevailing wind in summer? If only two or three rows of corn are 
planted in a garden where prevailing winds occur, in which direction had they better rum?

Although most flowers are of such character as to insure or increase the chances of cross-pollination, there are some that absolutely forbid crossing. These flowers are usually borne beneath or on the ground, and they lack showy colours and perfumes. They are known as cleistogamous flowers (meaning self-fertilizing flowers). The plant has normal showy flowers that may be insect-pollinated, and in addition is provided with these simplified flowers. Only a few plants bear cleistogamous flowers. Hogpeanut, common blue violet, fringed wintergreen, and dalibarda are the besi subjects in this country. Fig. 205 shows a cleistogamous flower of the blue violet at $\alpha$. Above the

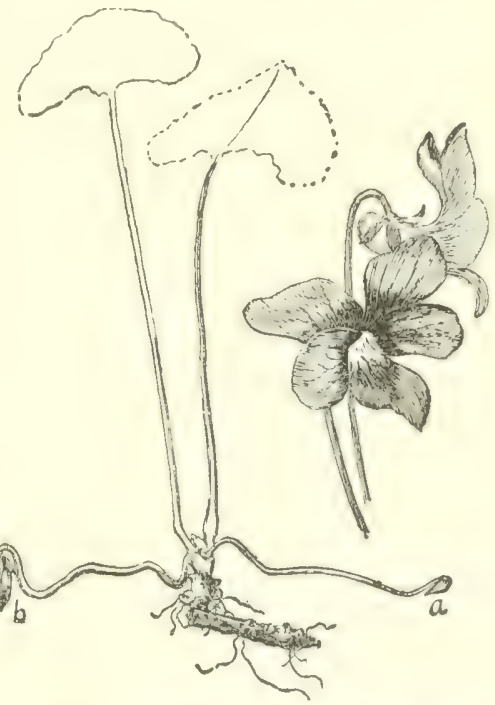

Fig. 205. - Common Biuf VIorift. The familiar flowers are shown, natural size. The corolla is spurred. Late in the season, cleistogamous flowers are often borne on the surface of the ground. A small one is shown at $a$. A neariy mature port is shown at $b$. Both $a$ and $b$ are one third natural size.

true roots, slender stems bear these flowers, that are provided with a calyx, and a curving corolla which does not open. Inside are the stamens and the pistils. Late in the season the deistogamous flowers may be found just underneath the mould. 'micy never nive above ground. The following summer one may find a secaling plant, i: 
some kinds of plants, with the remains of the old cleistogamous flower still adhering to the root. Cleistogamous flowers usually appear after the showy flowers have

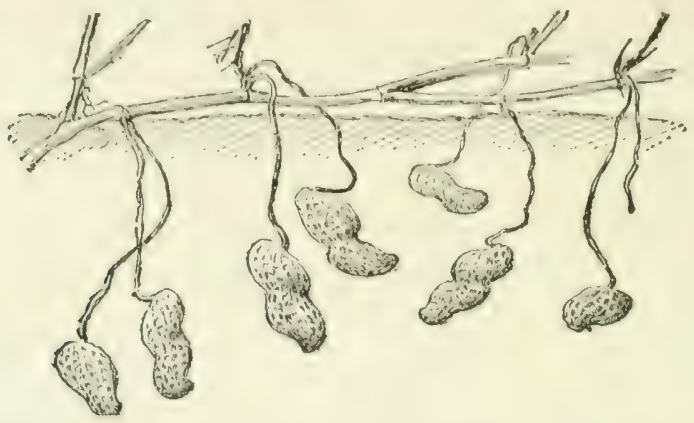

Fig. 206. - PODS OF PEANUTS RIPENING UNDERGROUND.

passed. They seem to insure a crop of seed by a method that expends little of the plant's energy. The pupil will be interested to work out the fruiting of the pea-

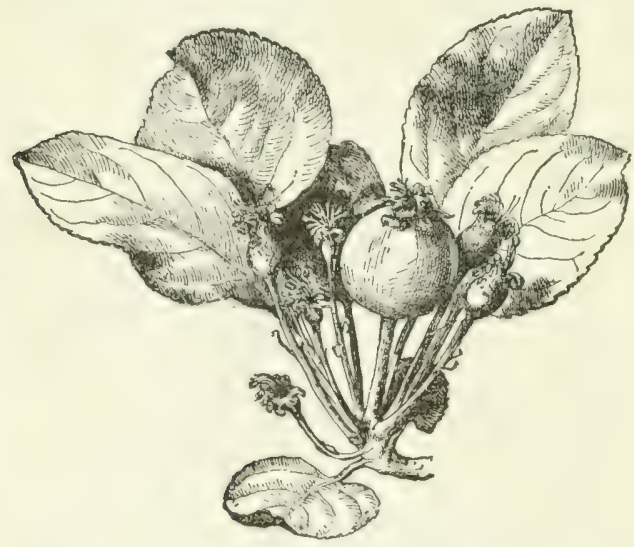

Fig. 207.-STRUGGLE FOR EXISTENCE AMONG THE APPLE Flowers. nut (Fig. 206). Unbaked fresh peanuts grow readily and can easily be raised in Canada. in a warm sandy garden.

SugGestions. 152. Not all the flowers produce seeds. Note that an apple tree may bloom very full, but that only relatively few apples may result (Fig. 207). More poilen is froduced than is nceded to fertilize the flowers; this increases the chances that sufficient 
stigmas will receive acceptable pollen to enable the plant to perpetuate its kind. At any time in summer, or even in fall, examine the apple trees carefully to determine whether any dead flowers or lower stalks still remain ahout the apple; or, examine any full-blooming plant to see whether any of the flowers fail. 153. Keep watch on any plant to see whether insects visit it. What kind? When? What for? 154. Determine whether the calyx serves any purpose in protecting the flower. Very carefully remove the calyx from a bud that is normally exposed to heat and sun and rain, and see whether the flower then fares as well as others. 155. Cover a single flower on its plant with a tiny paper or muslin bag so tightly that no insect can get in. If the flower sets fruit, what do you conclude? 156. Remove carefully the corolla from a flower nearly ready to open, preferably one that has no other flowers very close to it. Watch for insects. 157. Find the nectar in any flower that you study. 158. Remove the stigma. What happens? 159. Which of the following plants have perfect flowers: pea, bean, pumpkin, cotton, clover, buckwheat, potato, Indian corn, peach, chestnut, hickory, watermelon, sunflower, cabbage, rose, begonia, geranium, cucumber, calla, willow, cottonwood, cantaloupe? What have the others? 160. On windpollinated plants, are either anthers or stigmas more numerous? 161. Are very small eolourent flowers usually borne singly or in clusters? 162. Why do rains at blooming time often lessen the fruit crop? 163. Of what value are bees in orchards? 164. The crossing of plants to improve a'arietics or to allain newe zarieties. - It may be desired to perform the operation of pollination by hand. In order to insure the most definite results, every effort should be made rightly to apply the pollen which it is desireci shall be used, and rigidly to exclude all other pollen. (a) 'Th' first requisite is to remove the anthers from the flower which it is proposed to cross, and they must be rmoved before the pollen has been shed. The flower-bud is therefore opened and the anthers taken out. Cut off the floral envelopes with small, sharppointed scissors, then cut out or pull out the anthers, leaving only the pistil untouched; or merely open the corolla at the end and pull out the anthers with a hook or tweezers; and this method is often the best one. It is best to delay the operation as long as possible and yet not allow the bud to open (and thereby expose the flower to foreign pollen) nor the anthers to discharge the pollen. (b) The flower must nevt lie corecred with a papper bay to preient the access of pollen (Figs. 208, 209). If the stigma is not receptive at the time (as it usually is not), the desired prollen is not applied at once. The bag may be remover from time to time to allow of examination of the pistil, and when the stigma is mature, which is told by its glutinous or roughened appearance, 
the time for pollination has come. If the bag is slightly moistened, it can be puckered more tightly about the stem of the plant. The time reyuired for the stigma to mature varies from several hours to a few dias. (i) When the stigma is ready, an unopened antiner from the desired flower is crushed on the finger nail or a knife blate, and the pollen is rubbed on the stigma by means of a tiny brush, the point of a knife blade, or a sliver of wood. The

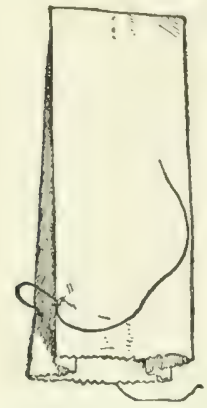

FIG, 208. - A PAPER BAG, with string inserted.

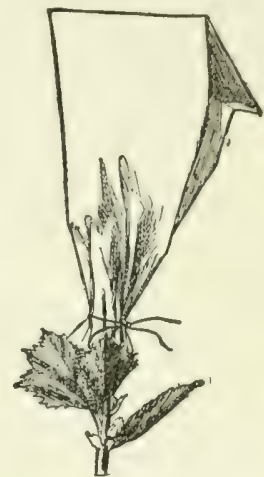

FIG. 209. - THE BAG TIED OVER A FLOWER.

flower is again covered with the bag, which is allowed to remain for several days until all danger of other pollination is past. Care must be taken completely to cover the stigmatic surface with pollen, if possible. 'The seeds produced by a crossed flower produce hybrids, or plants having parents belonging to different varieties or species. 165. One of the means of securing new forms of plants is by making hybrids. Why?

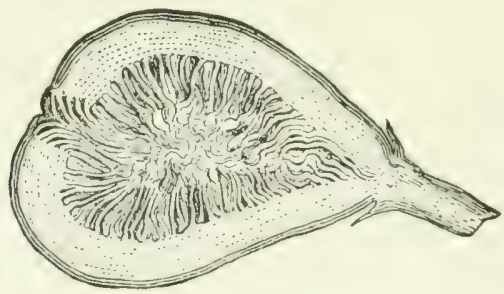

FIG, 2ro. - The fig is a hol'ow torus with flowers borne on the inside, and polunated by insects that en er at the apex. 


\section{CHAPTER XX}

\section{FLOWER-CLUSTERS}

Origin of the Flower-cluster. - We have seen that branches arise from the axils of leaves. Sometimes the leaves may be reduced to bracts and yet branches are borne in their axils. Some of the branches grow into long limbs; others become short spurs; others bear flowers. In fact, a flower is itself a specialized branch.

Flowers are usually borne near the top of the plant. Often they are produced in great numbers. It results, therefore, that flower branches usually stand close together, forming a cluster. The shape and the arrangement of the flower-cluster differ with the kind of plant, since each plant has its own mode of branching.

Certain definite or well-marked types of flower-clusters have re. ceived names. Some of these names we shall discuss, but the

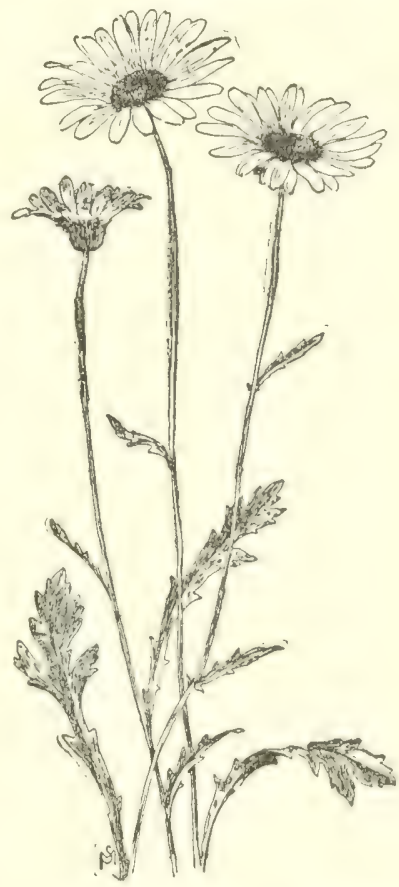

FIG, 2II. - TERMINAL FLOWERS OF THE WHITEIVEED (in some places called ox-eye daisy). flower-clusters that perfectly match the definitions are the exception rather than the rule. The determining of the 
kir 's of flower-clusters is one of the most perplexing stibjects in descriptive botany. We may classify the subject aronnd three ideas: solitary flowers, centrifugal or determinate clusters, centripetal or indeterminate clusters.

Solitary Flowers. - In many cases flowers are borne singly; they are separated from other flowers by leaves. They are then said to be solitary. The solitary flower may

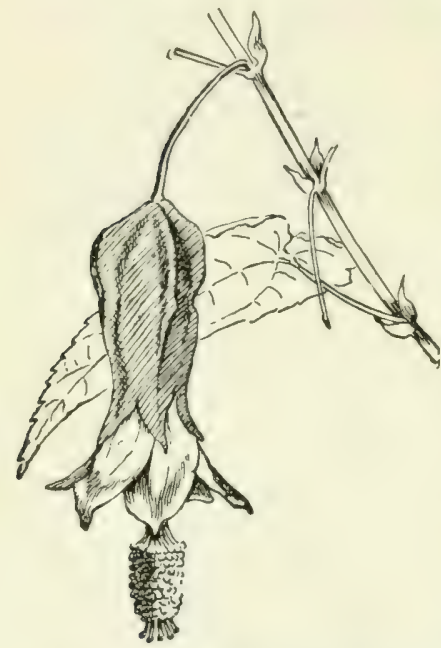

Fig. 212.-I LATERAL Flower of AN ABUtilon. A greenhouse plant. be either at the end of the main shoot or axis (Fig. $2 \mathrm{II}$ ), when it is said to be terminal; or from the side of the shoot (Fig. 212), when it is said to be lateral or axillary.

Centripetal Clusters. - If the flower-bearing axils were rather close together, an open or leafy flower-cluster might result. If the plant continues to grow from the tip, the older flowers are left farther and farther behind. If the cluster were so short as to be flat or convex on top, the outermost flowers would be the older. A flower-cluster in which the lower or outer flowers open first is said to be a centripetal cluster. It is sometimes said to be an indeterminate cluster, since it is the result of a type of growth which may go on more or less continuously from the apex.

The simplest form of a definite centripetal cluster is a raceme, which is an open elongated cluster in which the flowers are borne singly on wry short branches and open from below (that is, from the older part of the shoot) 
upwards (Fig. 2I3). The raceme may be tominal to the main branch; or it may be lateral to it, as in Fig. 214.

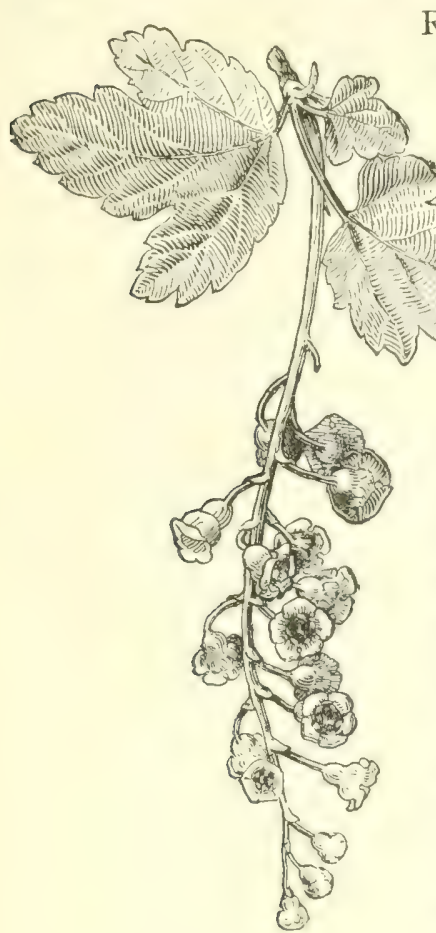

Fig. 213. - RACEME OF CURRANT.

Racemes often bear the flowers on one side of the stem, thus forming a single row. When a centripetal flowercluster is long and dense and the flowers are sessile or nearly so, it is called a spike (Fig. 2I5). Common examples of spikes are plantain, mignonette, mullein.

A very short and dense spike is a head. Clover (Fig. 2I6) is a good example. The sunflower and related plants bear many small flowers in a very dense and often flat head. Note that in the sunflower (Fig. I 89) the outside or exterior flowers

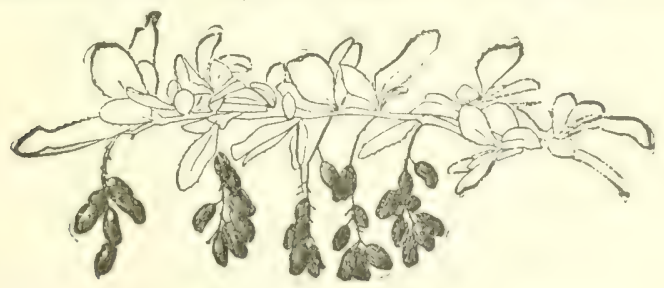

Fig. 2I4. - Lateral Racemes (in fruit) of BarberRy。

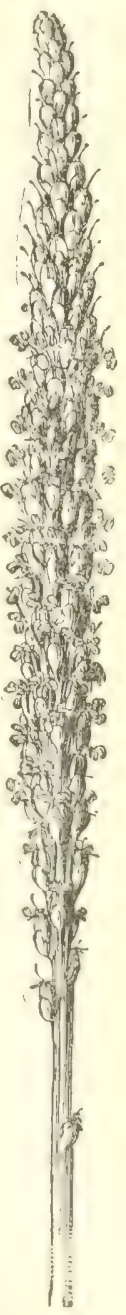

FIG. 215.SPIKE OF Plantain. 
open first. Another special form of spike is the catkin, which usually has scaly bracts, the whole cluster being deciduous after flowering or fruiting, and the flowers (in typical cases) having only stamens or pistils. Examples

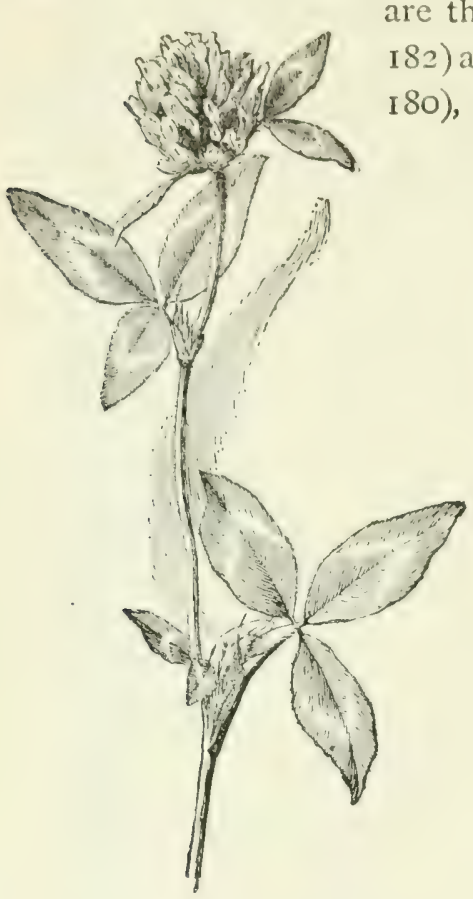

FIG. 216. - HEAD OF CLOVER BLOSSOMS.

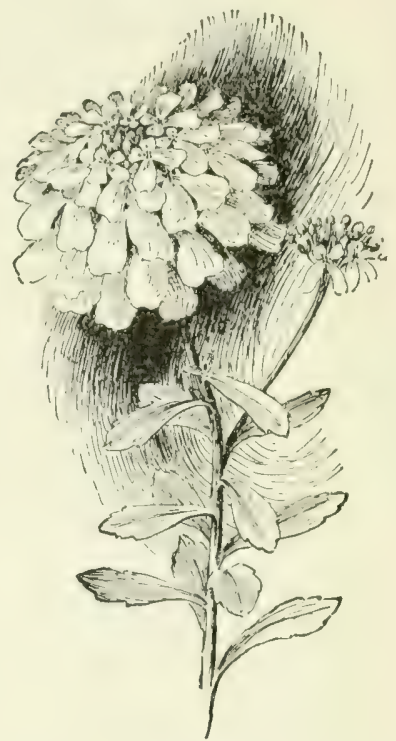

FIG. 2I7.- CORYMB OF CANDYTUFT.

When a loose, elongated centripetal flower-cluster has some primary branches simple, and others irregularly branched, it is called a panicle. It is a branching raceme. Because of the earlier growth of the lower branches, the panicle is usually broadest at the base or conical in outline. True panicles are not very common.

When an indeterminate flower-cluster is short, so that 
the top is convex or flat, it is a corymb (Fig. 2I 7 ). The outermost flowers open first. Centripetal flower-clusters are sometimes said to be corymbose in mode.

When the branches of an indeterminate cluster arisc from a common point, like the frame of an umbrella, the cluster is an umbel (Fig. 2is). Typical umbels occur in carrot, parsnip, caraway, and other plants of the parsley family: the family is known as the Umbellifera, or umbel-bearing

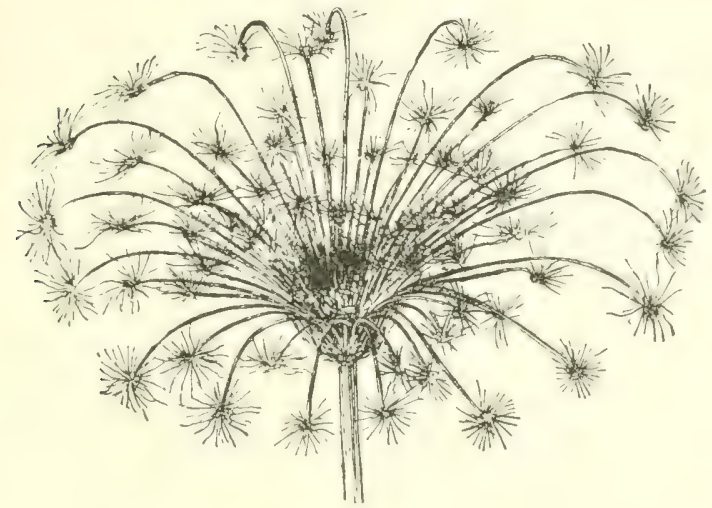

Fig, 218, - REMAINS OF a LAST YeAR's UMBEL OF Witd CARRot.

family. In the carrot and many other Umbellifere, there are small or secondary umbels, called umbellets, at the end of each of the main branches. (In the centre of the wild carrot umbel one often finds a single, blackish, often aborted flower, comprising a I-flowered umbellet.)

Centrifugal or Determinate Clusters. - When the terminal or central flower opens first, the cluster is said to be centrifugal. The growth of the shoot or cluster is determinate, since the length is definitely determined or stopped by the terminal flower. Fig. 219 shows a determinate or centrifugal mode of flower bearing. 


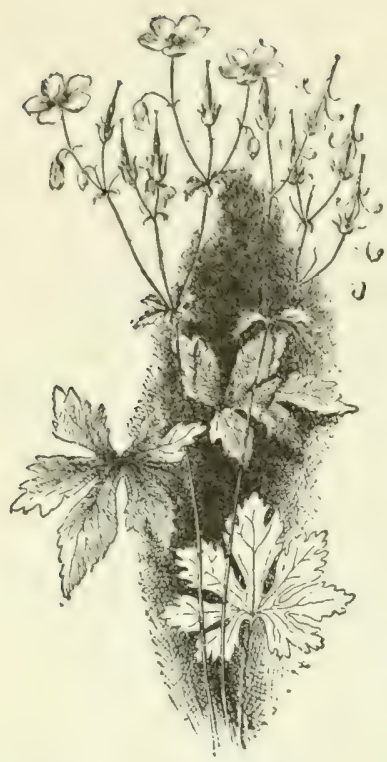

FIG. 219.- DETERMINATE OR CYMOSE ARRANGEMENT. Wild geranium.

Dense centrifugal clusters are usually flattish on top because of the cessation of growth in the main or central axis. These compact flower-clusters are known as cymes. Centrifugal clusters are sometimes said to be cymose in mode. Apples, pears (Fig. 220), and elders bear flowers in cymes. Some cyme-forms are like umbels in general appearance. A head-like cymose cluster is a glomerule; it blooms from the top downwards rather than from the base upwards.

Mixed Clusters. - Often the cluster is mixed, being determinate in one part and indeterminate in another part of the same cluster. The main cluster may be indeterminate, but the branches determinate. The cluster has the appearance of a panicle, and is usually so called, but it is really a thyrse. Lilac is a familiar example of a thyrse. In some cases the main cluster is determinate and the branches are indeterminate, as in hydrangea and elder.

Inflorescence. - The mode or method of flower arrangement is known as the inflorescence. That is, the inflorescence is cymose, co-

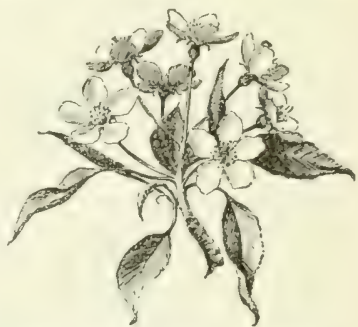

FIG. 220.-CYME OF PEAR. Often imperfect. rymbose, paniculate, spicate, solitary, determinate, indeterminate. By custom, however, the word "inflorescence" 

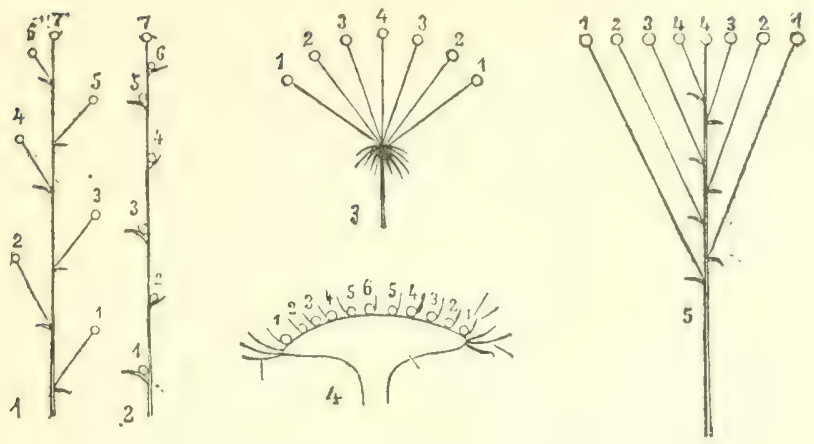

FiG. 22t. - Forms OF CENTRIPETAl Flower-Clusters.

I, raceme; 2 , spike; 3 , umbel; 4 , head or anthodium; 5 , corymb.

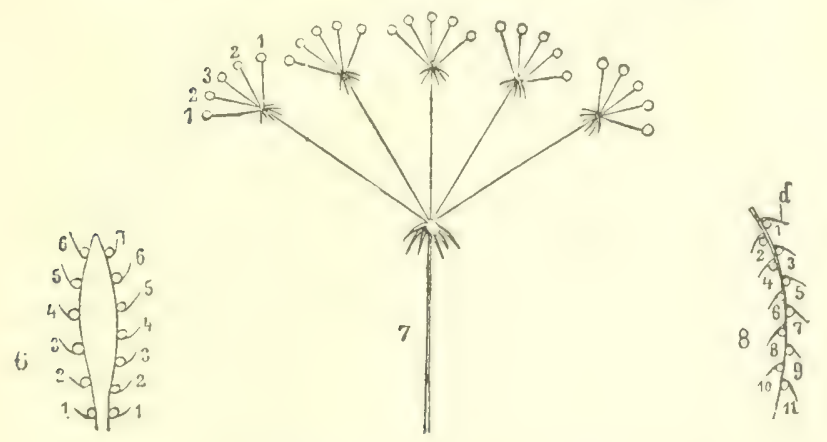

Fig. 222. - CENTRIPETAL INFLORESCENCE, continued.

6, spadix; 7 , compound umbel: 8 , catkin.

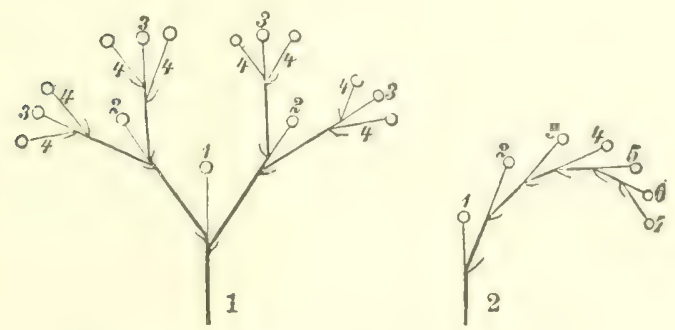

FIG. 223. - CENTRIFUGAL INFLORESCENCE.

I, cyme; 2 , scirpioid raceme (or half cyme). 
hats come to be used in works on deseriptive hotany for the flouer-chuster itself. 'Thus a cyme or a pandele may be called an inflorescence. It will be seen that even solitary flowers follow either indeterminate or determinate methods of branching.

The flower-stem. - The stem of a solitary flower is known as a peduncle; also the general stem of a flowerclustir. The stem of the individual flower in a cluster is a pedicel. In the so-called stemless plants the peduncle may arise directly from the ground, or crown of the plant, as in dandelion, hyacinth, garden daisy; this kind of peduncle is called a scape. A scape may bear one or many flowers. It has no foliage leaves, but it may have bracts.

Suggestions. - 166. Name six columns in your notebook as follows: spike, raceme, corymb, umbel, cyme, solitary. Write each of the following in its appropriate column: larkspur, grape, rose, wistaria, onion, bridal wreath, banana, hydrangea, phlox, China berry, lily-of-the-valley, Spanish dagger (or yucca), sorghum, tuberose, hyacinth, mustard, goldenrod, peach, hollyhock, mullein, crêpe myrtle, locust, narcissus, snapdragon, peppergrass, shepherd's purse, coxcomb, wheat, hawthorn, geranium, carrot, elder, millet, dogwood, castor bean; substitute others for plants that do not grow in your region. 167. In the study of flowerclusters, it is well to choose first those that are fairly typical of the various classes discussed in the preceding paragraphs. As soon as the main types are well fixed in the mind, random clusters should be examined, for the pupil must never receive the impression that all flower-clusters follow the definitions in books. Clusters of some of the commonest plants are very puzzling, but the pupil should at least be alile to discover whether the inforescence is determinate or indeterminate. theoretical morles of initorescence. Figures $2: 1$ to $2:-3$ illustrate the of opening. 


\section{CHAPTER XXI}

\section{FRUITS}

THE ripened ovary, with its attachments, is known as the fruit. It contains the seids. If the pistil is simple, or of one carpel, the fruit also will have one compartment. If the pistil is compound, or of more than one carpel, the fruit usually has an equal number of compartments. The compartments in pistil and fruit are known as 10cules (from Latin locus, meaning "a place").

The simplest kind of fruit is a ripened I-loculed ovary. The first stage in complexity is a ripened 2-or

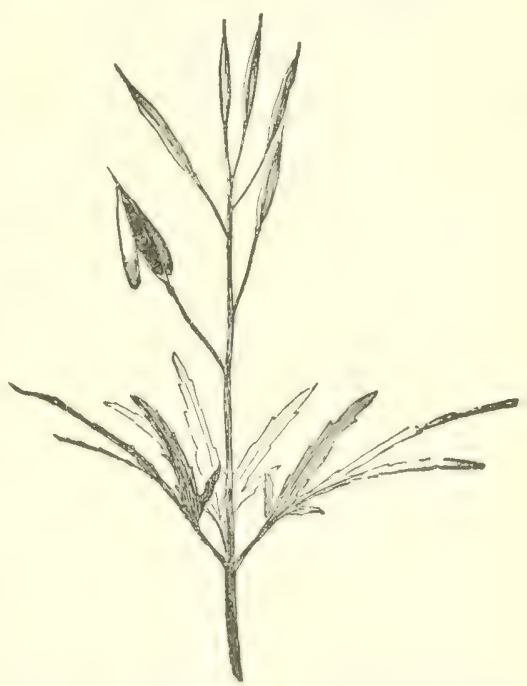

FIG. 224. - DENTARIA, OR TOOTH-WORT, in fruit.

many-loculcd oxary. Very complex forms may arise by the attachuncut of other parts to the ovary. Sometimes the style persists and becomes a beak (mustard pods, dentaria, Fig. 224), or a tail as in clematis; or the calyx may be attached to the ovary; or the ovary may be embedded in the receptacle, and ovary and receptacle together constitute the fruit: or an involucre may become a part of the 
fruit, as possibly in the walnut and the hickory (Fig. 225), and the (anp of the arorn (Fig. 226). The dhestmut and the beech bear a prickly involucre, but the nuts,

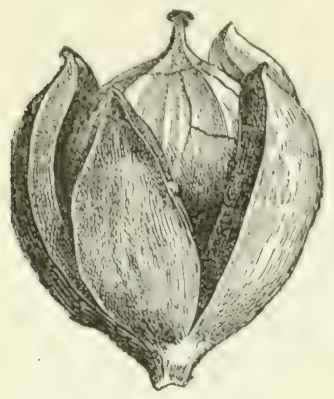

FIG. 225. - HICKORX-NUT.

'I'he nut is the fruit, contained in a husk.

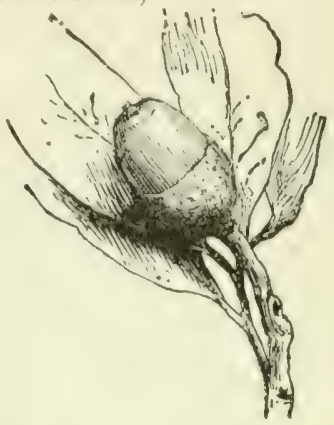

FIg. 226. - LIVE-OAK ACORN. The fruit is the "seed " part ; the involucre is the "cup."

or true fruits, are not grown fast to it, and the involucre can scarcely be called a part of the fruit. A ripened ovary is a pericarp. A pericarp to which other parts adhere has been called an accessory or reënforced fruit. (Page 169.)

Some fruits are dehiscent, or split open at maturity and liberate the seeds; others are indehiscent, or do not open.

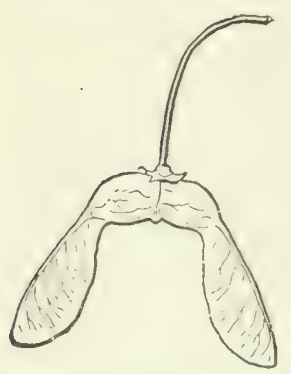

FIG. 227.- KEY OF

SUGAR MAPIE.

A dehiscent pericarp is called a pod.

The parts into which such

a pod breaks or splits are known as valves. In indehiscent fruits the seed is liberated by the decay of the envelope, or by the rupturing of the envelope by the germinating sced. Indehiscent winged peri- AMERICAN Eim. carps are known as samaras or key fruits. Maple (Fig. 227), elm (Fig. 228), and ash (Fig. 93) are examples. 
Pericarps. - The simplest pericarp is a dry, oneseeded, indehiscent body. It is known as an akene. A

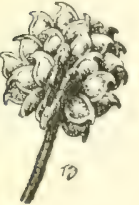

FIG. 229. AKENFS UF BUTTERCUP. head of akenes is shown in Fig. 229, and the structure is explained in Fig. 230. Akenes may be seen in buttercup, hepatica, anemone, smartweed, buckwheat.

A I-loculed pericarp which dehisces along the front edge (that is, the inner edge, next
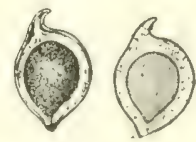

FIG. 230. - AKENES OF BUTTERCUP, one in longitudinal section.

the centre of the flower is a follicle. The fruit of the larkspur (Fig. 23I) is a follicle. There are usually five of

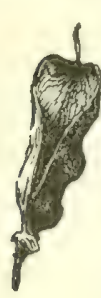

FIG. 23I. FOLLICLE OF LARKSPUR. these fruits (sometimes three or four) in each larkspur flower, each pistil ripening into a follicle. If these pistils were united, a single compound pistil would be formed. Columbine, peony, ninebark, milkweed, also have follicles.

A I-loculed pericarp that dehisces on both edges is a legume. Peas and beans are typical examples (Fig. 232); in fact, this character gives name to the pea family, - Leguminosæ.

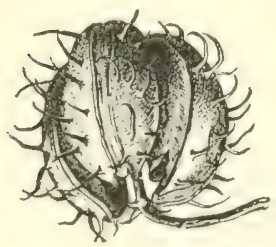

Fig. 233.- Capsule of CASTOR - OIL BEAN AFTER DEHISCENCE.

Often the valves of the legume twist forcibly and expel the seeds, throwing them some distance. The

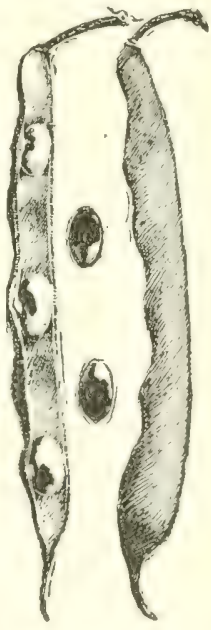

FIG. 232. - A

BEAN POD. word "pod" is sometimes restricted to legumes, but it is better to use it generically for all dehiscent pericarps.

A compound pod-dehiscing pericarp of two or more carpels - is a capsule (Figs. 233, 234, 


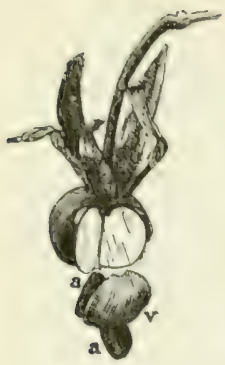

FIG. 234. - CAPSUIE OF MOKNING GLORY.

236, 237). Some capsules are of one locule, but they may have been compound when young (in the ovary stage) and the partitions may have vanished. Sometimes one or more of the carpels are uniformly crowded out by the exclusive growth of other carpels (Fig. 235). The seeds or parts which are crowded out are said to be abortid.

There are several ways in which capsules dehisce or open. When they break along the partitions (or septa), the mode is known as septicidal dehiscence (Fig. 236); In septicidal dehiscence the fruit separates into parts representing the original carpels. These carpels may still be entire, and they then dehisce individually, usually along the inner
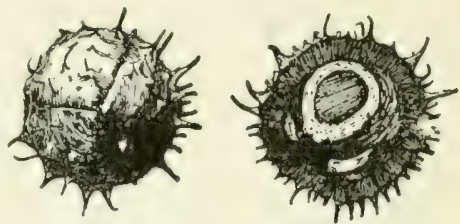

FIG, 235. - THREE-CARPELED FRUIT of HoRse-chestnut. Two locules are closing by abortion of the ovules. edge as if they were follicles. When the compartments

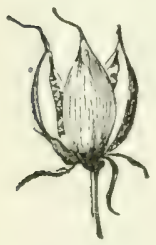

FIG. 236. -

Si. Jolix's Worr. Septicidal.

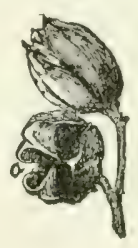

FIG. 237. LOCULIC: IAL POD OF DAY-LILY. split in the middle, betruccn the partitions, the mode is loculicidal dehiscence (Fig. 237). In some cases the dehiscence is at the top, when it is said to be apical (al. though several modes of dehiscence are here included). When the wliole top comes off, as in purslane and garden portulaca (Fig. 238), the pod is known as a pyxis. In some cases apical dehiscence is by means of a hole or clefts.

The peculiar capsule of the mustard family, or Cruci- 
feræ, is known as a silique when it is distinctly longer than broad (Fig. 224), and a silicle when its breadth nearly

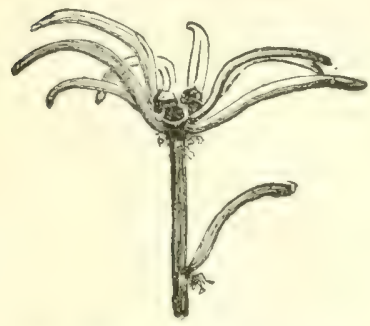

FIG. 238. - PYXIS OF PORTULACA OR ROSE-MOSS.

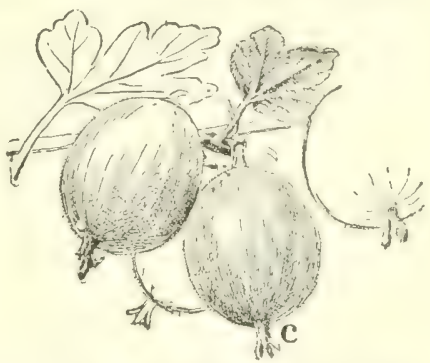

FIG, 239. - BERRIES OF GOOSEBERRY. Remains of calyx at $c$.

equals or exceeds its length. A cruciferous capsule is 2-carpeled, with a thin partition, each locule containing seeds in two rows. The two valves detach from below upwards. Cabbage, turnip, mustard, water-cress, radish,
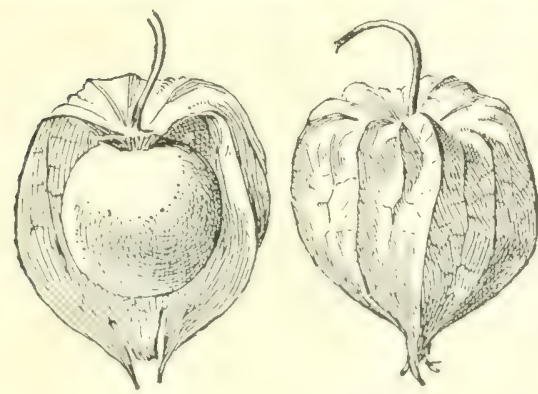

Fig. 240. - BerRY OF THE GRound CherRY OR HUSK TOMATO, contained in the inflated calyx.

The pericarp may be fleshy and indehiscent. A pulpy pericarp with several or many seeds is a berry (Figs. 239, 240, 24I). To the horticulturist a berry is a small, soft, edible fruit, without rape, shepherd's purse, sweet alyssum, wallflower, honesty, are examples.

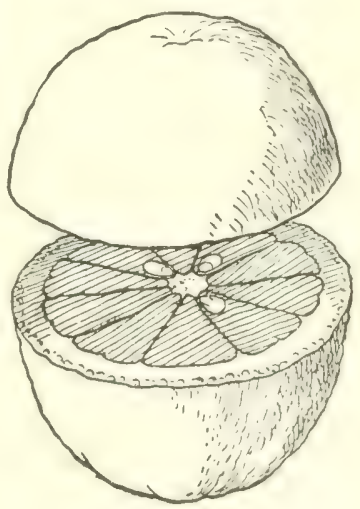

FIC. 2.II.- ORANGE; example of a Lerry. 
particular reference to its structure. The botanical and horticultural conceptions of a berry are, therefore, unlike. In the botanical sense, sooseberries, currants, grapes, tomatoes, potato-balls, and even eggplant fruits and oranges (Firg. 24I) are berries; strawberries, raspberries, blackberries are not.

A fleshy pericarp containing one relatively large seed or stone is a drupe. Examples are plum ( Fig. 242), peach,

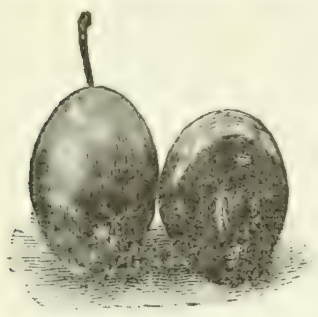

FIG, 242. - PLUM ; example of a drupe. cherry, apricot, olive. The walls of the pit in the plum, peach, and cherry are formed from the inner coats of the ovary, and the flesh from the outer coats. Drupes are also known as stonc-fnits.

Fruits that are formed by the subsequent union of separate pistils are aggregate fruits. The carpels in aggregate fruits are usually more or less fleshy. In the raspberry and the blackberry flower, the pistils are essentially distinct, but as the pistils ripen they cohere and form one body (Figs. 243, 244).
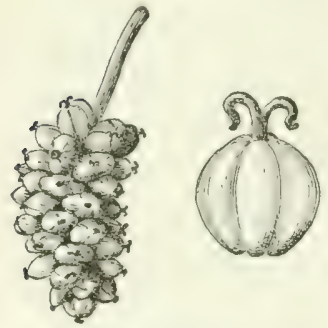

FIG. 24.4. - AGCREGATE Fruit OF MUlderRY: and a separate fruit.

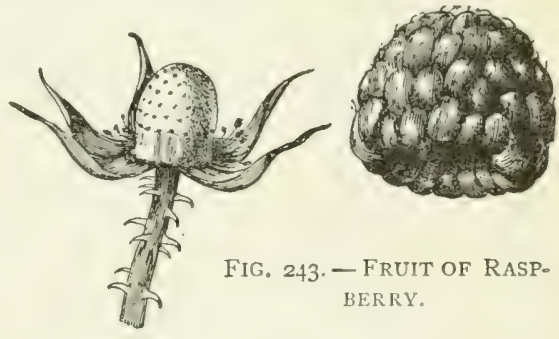

Each of the carpels or pistils in the raspberry and the blackberry is a little drupe or drupslet. In the raspberry the entire fruit separates from the torus, leaving the torus on the plant. In the llacklserry and 
the dewbery the fruit adheres to the torus, and the two are removed together when the fruit is picked.

Accessory Fruits. - When the pericarp and some other part grow together, the fruit is said to be accessory or

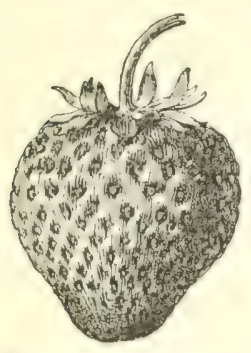

FIG. 2.45. - STRAWLERRY; fleshy torus in which akenes are embedded. reënforced. An example is the strawberry (Fig. 245). The edible part is a greatly cnlarged toms, and the pericarps are akenes embedded in it. These akenes are commonly called seeds.

Various kinds of reënforced fruits have received special names. One of these is the hip, characteristic of roses. In this case, the torus is deep and hollow, like an urn, and the separate akenes are borne inside it. The mouth of the receptacle may close, and the walls sometimes become fleshy; the fruit may then be mistaken for $x$ berry. The fruit of the pear, apple, and quince is known as a

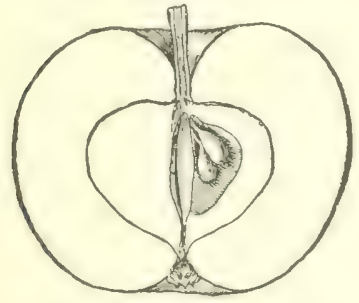

FIG. 2.16. - SECTIUN OF AN APPLE.

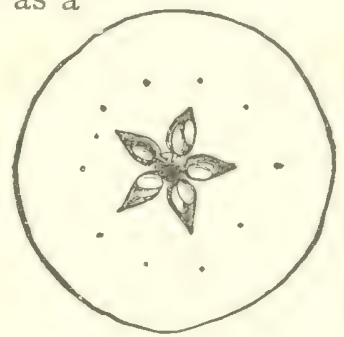

FIG. 247 - CROSS-SECTION OF AN f-PPIE.

pome. In this case the five united carpel; are completely buried in the hollow torus, and the torus makes most of the edible part of the ripe fruit, while the pistils are represented by the core (Fig. 246). Observe the sepals on the top of the torus (apex of the fruit) in Fig. 246. Note the outlines of the embedded pericarp in Figr. 247. 
Gymnospermous Fruits. - In pine, spruces, and their kin, there is no fruit in the sense in which the word is used in the preceding pages, because there is no orary. The ovules are naked or uncovered, in the axils of the scales of the young cone, and they have neither style nor stigma. The pollen falls directly on the mouth of the ovule. The orule ripens into a seed, which is usually winged. Because the ovule is not borne in a sac or ovary, these plants are called gymnosperms (Greek for "naked seeds”). All the true cone-bearing plants are of this class; also certain other plants, as red cedar, juniper, yew. The plants are monocious or sometimes diocious. The staminate flowers are mere naked stamens borne beneath scales, in small yellow catkins which soon fall. The pistillate flowers are naked ovules beneath scales on cones that persist (Fig. 29). Gymnospermous seeds may have several cotyledons.

Siggestions,-168. Study the following fruits, or any fire fruits "hosen by the teacher, and answer the questions for each: Apple, veach, bean, tomato, pumpkin. What is its form? Locate the sear left by the stem. Bv what kind of stem was it attached? Are there any remains of the blossom at the blossom end? Describe texture and colour of surface. Divisle the fruit into the seed ressel and the surrome!ing part. Tlas the fruit any pulp or flesh? Is it within or without the ssed vessel? Is the seed vessel simple or sub-divided? What is the number of seeds? Are the seeds free, attached to the wall of the vessel, or to a support in the centre? Are they arranged in any order? What kind of wall has the seed ressel? What is the difference between a peach stone and a peach seed? 169. The nut fruits are always available for study. Note the points suggested above. Determine what the meat or elible part represents, whether cotyleclons or not. Figure 248 is suggestive. 170. Mention all the fleshy fruits you know, tell where they come from, and refer them to their proper gromps. 171. That kinis of fruit can you bur in the market, and to what gromps or classes do they belong? Of which fruits are the seeds only, and not the pericarps, eaten? 172. An ear of corn is always arailable for stuly. What is it-a fruit or a collection of fruits? How are the grains aranged on the cob? How many rows do you count on each of several ears? Are all the rows on an ear 
equally, close together? Do you find an ear. with an odd number of rows? How do the parts of the husk overlap? Does the husk serve as protection from rain? Can birds pick out the grains? How do insect enemies enter the ear? How and when do weevils lay eggs on corn? 173. Study a grain of corn. Is it a sect? Describe the shape of a grain. Colour. Size. Does its surface show any projections or depressions? Is the seed-coat thin or thick? Transparent or opaque? Locate the hilum. Where is the silk scar? What is the silk? Sketch the grain from the two points of view that show it best. Where is the embryo? Does the grain have endosperm ? What is dent corn? Flint corn? How many kinds of corn do you know? For what are they used?
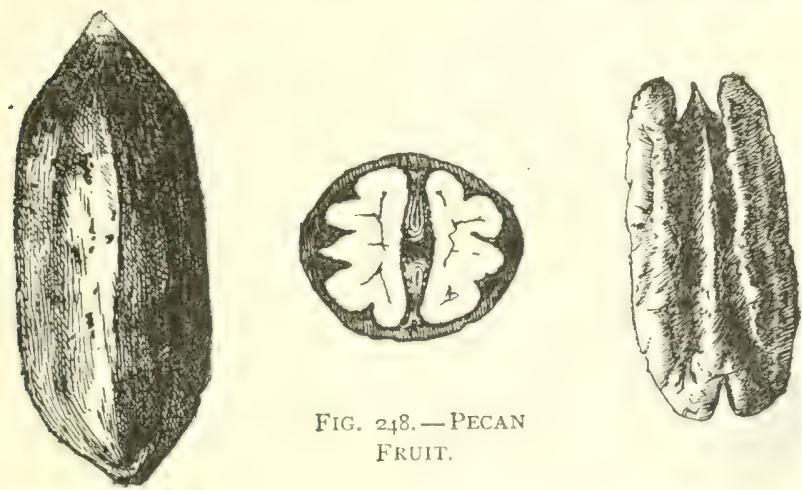

Note to TeAcher.-There are few more interesting subjects to beginning pupils than fruits, - the porls of many kinls, forms, and colours, the berries, and nuts. This interest may well be utilized to make the teaching alive. All common edible fruits of orchard and vegetable garten should be hrought into this liscussion. Of dry fruits, as pods, burs, nuts, collections may be made for the school museum. Fully mature fruits are best for study, particularly if it is desired to see dehiscence. For comparison, pistils and partially grown fruits should be had at the same time. If the fruits are not ripe enough to dchisce, they may be placed in the sun to dry. In the school it is well to have a collection of fruits for study. The specimens may be kept in glass jars. Always note exterior of frut and its parts; interior of fruit with arrangement and attachment of conients. 


\section{CHAPTER XXII}

\section{DISPERSAL OF SEEDS}

IT is to the plant's advantage to have its seeds distributed as widely as possible. It has a bettcr chance of surviving in the struggle for cristence. It gets away from competition. Many seeds and fruits are of such character as to increase their chances of wide dispersal. The commonest means of dissemination may be classed under four heads: explosive fruits; transportation by wind; transportation by birds; burs.

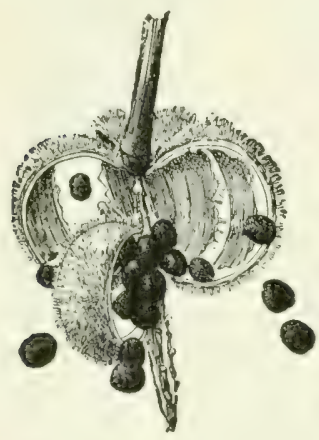

FiG. 249. $\rightarrow$ EXPLOSION OF THE Balsam POD.

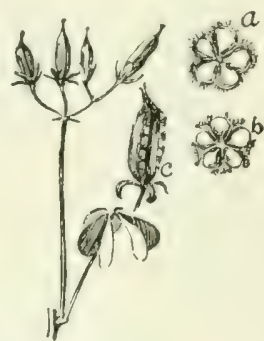

FIG. 250.-Explosive FRUITS OF OXALIS.

An exploding pod is shown at $c$. The dehiscence is shown at $b$. The structure of the pod is seen at $a$.

Explosive Fruits. - Some pods open with explosive force and discharge the seeds. Even beans and everlasting peas do this. More marked examples are the locust, witch hazel, garden balsam (Fig. 249), wild jewel-weed or impatiens (touch-me-not), violet, crane's-bill or wild geranium, bull nettle, morning glory, and the oxalis (Fig. 250). The 
oxalis is common in several species in the wild and in cultivation. One of them is known as wood sorrel. Figure 250 shows the common yellow oxalis. The pod opens loculicidally. The elastic tissue suddenly contracts when dehiscence takes place, and the seeds are thrown violently. The squirting cucumber is easily grown in a garden (procure seeds of seedsmen), and the fruits discharge the seeds with great force, throwing them many feet.

Wind Travelers. - Wind-transported seeds are of two general kinds: those that are provided with wings, as the flat seeds of catalpa (Fig. 25I) and cone-bearing trees and the samaras of ash, elm, tulip-tree, ailanthus, and maple; and those which have feathery buoy's or paraclutes to enable them to float in the air. Of the latter kind are the fruits of many composites, in which the pappus is copious and soft. Dandelion and thistle are examples. The silk of the milkweed and probably the hairs on the cotton seed have a similar office, and also the wool of the cat-tail. Recall the cottony seeds of the willow and the poplar.

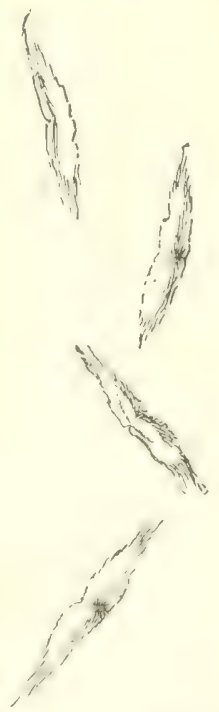

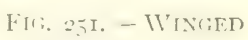
SEens of CATAlpa.

Dispersal by Birds. - Sceds of berics and of other small flesliy fruits are carricel far and wide by birds. The pulp is digested, but the seeds are not injured. Note how the cherries, raspberries, blackberries, June-berries, and others spring up in the fence rows, where the birds rest. Some berries and drupes persist far into winter, when they supply food to cedar birds, robins, and the winter birds. Red cedar is distributed by birds. Many of these pulpy 
fruits are agreeable as human food, and some of them have becil greatly enlarged or "improved" by the arts of the cultivator. The seeds are usually indigestible.

Burs. - Miny seeds and fruits bear spines, hooks, and hairs, which athere to the coats of animals and to clothing. The burdock has an involucre with hooked scales, containing the fruits inside. The clotbur is also an involucre. Both are composite plants, allied to thistles, but the

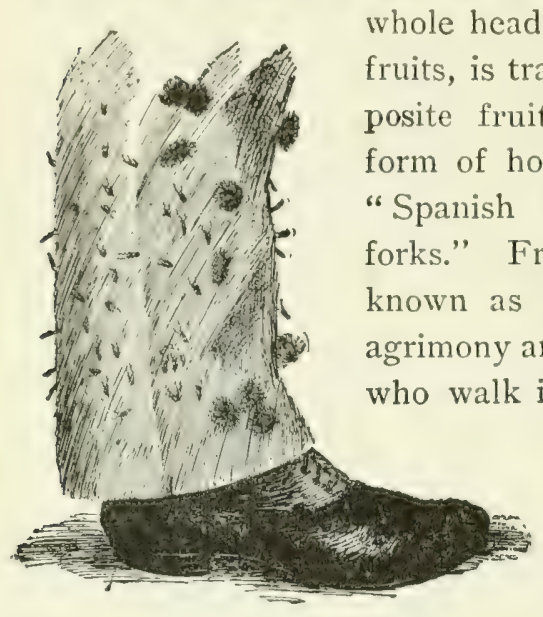

Fig. 252.-STEALING A RIDE.

mer and fall are aware that plants have means of disseminating themselves (Fig. 252). If it is impossible to identify the burs which one finds on clothing, the seeds may be planted and specimens of the plant may then be grown.

Suggestions. - 174. What advantage is it to the plant to have its seeds widely dispersed? 175. What are the leading ways in which fruits and seeds are dispersed? 176. Name some explosive fruits. 177. Describe wind travelers. 178. What seeds are carried by birds? 179. Describe some bur with which you are familiar. 180. Are adhesive fruits usually dehiscent or indehiscent? 181. Do samaras grow on low or tall plants, as a rule? 182. Are the cotton finres on the seed or on the fruit? 183. Name the ways in which the common weerls of your region are disseminated. 184. This lesson will suggest other ways in which 
seeds are transported. Nuts are buried by squirrels for food; but if they are not eaten, they may grow. 'The seeds of many plants are blown on the snow. The old stalks of weeds, standing through the winter, may serve to disseminate the plant. Seeds are carried by water down the streams and along shores. About woollen mills strange plants often spring up from seed brought in the fleeces. Sometimes the entire plant is rolled for miles before the winds. Such plants are "tumbleweeds." Examples are Russian thistle, hair grass or tumblegrass (Panicum cafillare), cyclone plant (Cycloloma platyphyllum), and white amaranth (Amarantus albus). About seaports strange plants are often found, having been introduced in the earth that is used in ships for ballast. These plants are usually known as "ballast plants." Most of them do not persist long. 185. Plants are able to spread themselves by means of the great numbers of seeds that they produce. How many seeds may a given elm tree or apple tree or raspberry bush produce?

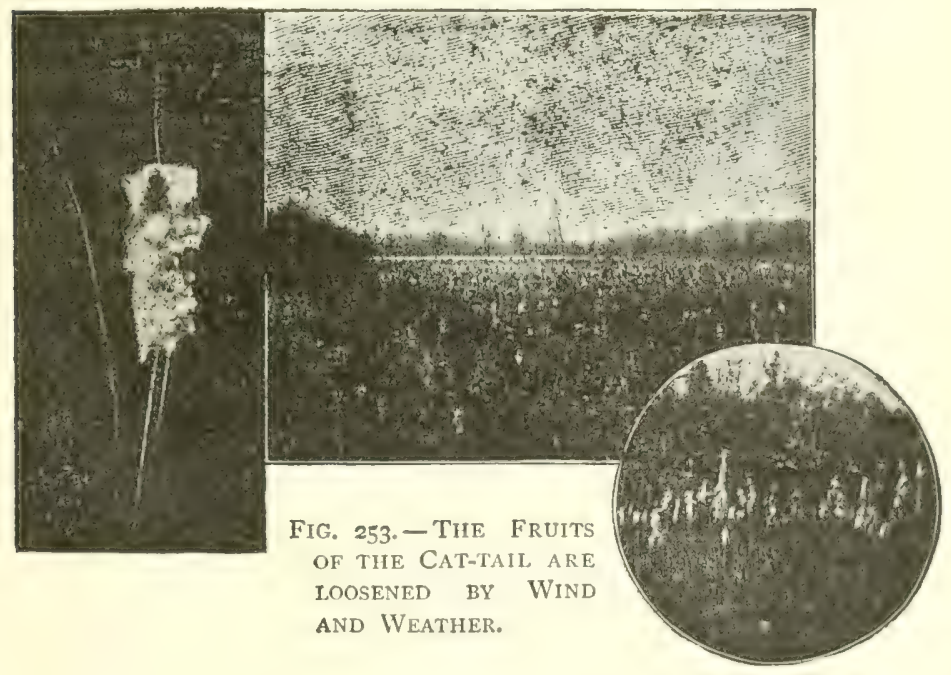




\section{CHAPTER XXIII \\ PHENOGAMS AND CRYPTOGAMS}

THE plants thus far studied produce flowers; and the flowers produce seeds by means of which the plant is prop-

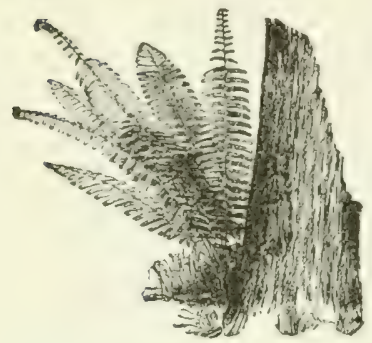

FIG. 254. - ChRISTMAS FERN.

- Dryopteris acrostichoides; known also as Aspidium. agated. There are other plants, however, that produce no seeds, and these plants (including bacteria) are probably more numerous than the seed-bearing plants. These plants propagate by means of spores, whichare gencrative cells, usually simple, containing no embryo. These spores are very small, and sometimes are not visible to the naked eye.

Prominent among the sporepropagated plants are ferns. The common Christmas ferm (so called because it remains green during winter) is shown in Fig. 254. The plant has no trunk. The leaves spring directly from the ground. The leaves of ferns are called fronds. They vary in shape, as other leaves do. Some of the fronds in Fig. 254 are seen to be narrower at the top. If these are examined more closely (Fig. 255),

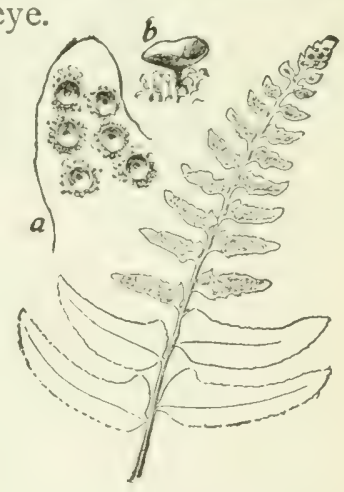

Fig. 255.-Fruiting Froxp of Christias Fern.

Sori at $a$. One sorus with its indusium at $b$. 
it will be seen that the leaflets are contracted and are densely covered beneath with brown bodies. These bodies are collections of sporangia or spore-cases.

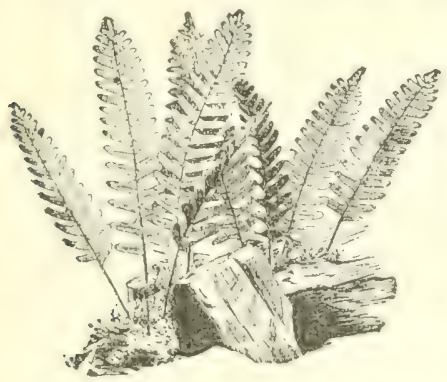

Fig. 256.- Common Polypode Fern. Polypadium vulgare.

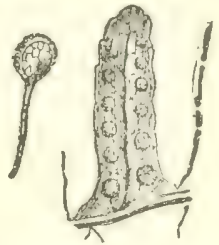

FIG. 257.- SORI AND SPORANGIUM OF POLYPODE. A chain of cells lies along the top of the sporangium, which springs back elastically on drying, thus disseminating the spores.

The sporangia are collected into little groups, known as sori (singular, sorus) or fruit-dots. Each sorus is covered with a thin scale or shield, known as an indusium. This indusium separates from the frond at its edges, and the sporangia are exposed. Not all ferns have indusia. The polypode (Figs. 256, 257) does not; the sori are naked. In the brake (Figr. 258)

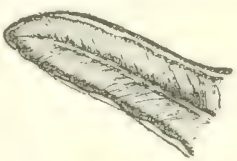

FIG. 258. - THE BRAKE FRUITS UNDERNEATH THE REVOLUTE EIGIS OF 1 HL LEAF.

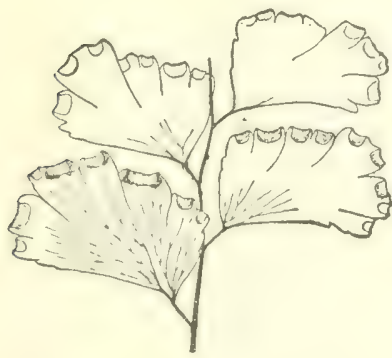

Fig. 259.-Fruiting Pinnules OF MAIDENHAIR FERN.

and maidenhair (Fig. 259) the edge of the frond turns over and forms an indusium. The nephrolepis or sword fern of greenhouses is allied to the polypode. The sori are in a single row on either side the midrib (Fig. 260). The indusium is circular or kidneyshaped and open at one edge 


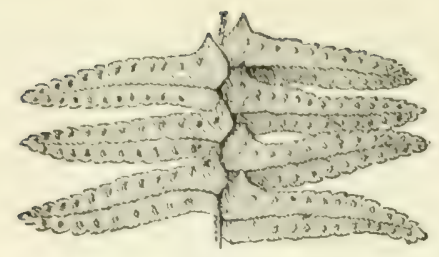

FIG, 260. - PART OF FROND OF SWORD FERN. To the pupil: Is this illustration right side up?

or finally all around. The Boston fern, Washington fern, Pierson fern, and others, are horticultural forms of the common sword fern. In some ferns (Fig. 26I) an entire frond becomes contracted to cover the sporangia.

The sporangium or spore-case of a fern is a more or less globular body and usually with a stalk (Fig. 257). It contains the spores. When ripe it bursts and the spores are set free.

In a moist, warm place the spores gcrminate. They produce a small, flat, thin, green, more or less heartshaped membrane (Fig. 262). This is the prothallus. Sometimes the prothallus is an inch or more across, but oftener it is less than a ten cent piece in size. Althougli easily seen, it is commonly unknown except to botanists. Prothalli may

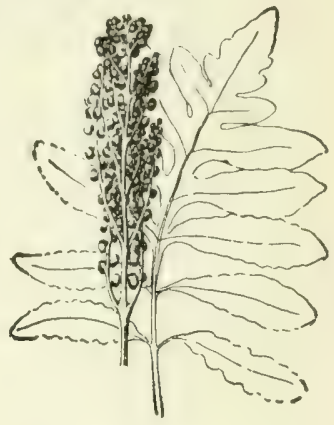

FIG, 26I.-FERTILE AND STERJLE FRONDS OF THE SENSITIVE FERN. often be found in greenhouses where ferns are grown.

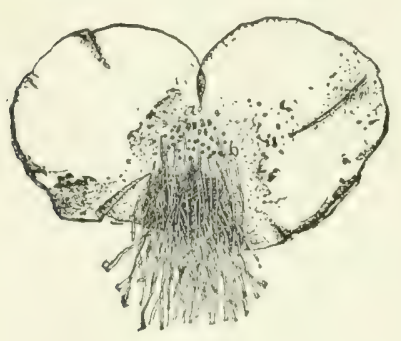

Fig. 262.-Prothallus of A FERN. Erilarged:

Archegonia at $a$; antheridia at $b$. Look on the moist stone or brick walls, or on the firm soil of undisturbed pots and beds; or spores may be sown in a damp, warm place.

On the under side of the prothallus two kinds of organs are borne. These are the archegonium (containing eggcells) and the antheridium (con- 
taining sperm-cells). These organs are minute specialized parts of the prothallus. Their positions on a particular prothallus are shown at $a$ and $b$ in Fig. 262, but in some ferns they are on separate prothalli (plant diøcious). The sperm-cells escupe from the antheridium and in the water that collects on the prothallus are carried to the archegonim, where fertilization of the egg takes place. From the fertilized egg-cell a plant grows, becoming a "fern." In most cases the prothallus soon dies. The prothallus is the gametophyte (from Greek, signifying the fertilized plant).

The fern plant, arising from the fertilized egg in the archegonium, becomes a perennial plant, each year producing spores from its fronds (called the sporophyte); but these spores - which are merely detached special kinds of cells - produce the prothallic phase of the fern plant, from which new individuals arise. A fern is firtilized but once in its lifime. The "fern" bears the spore, the spore gives rise to the prothallus, and the egg-cell of the prothallus (when fertilized) gives rise to the fern.

A similar alternation of generations runs all through the vegetable kingdom, although there are some groups of plants in which it is very obscure or apparently wanting. It is very marked in ferns and mosses. In algre (including the seaweeds) the gametophyte is the "plant," as the non-botanist knows it, and the sporophyte is inconspicuous. There is a general tondency, in the coulution of the vegetable kingdom, for the gametopliyte to lose its relatiac importance and for the sporophyte to become larger and more lighly deacloped. In the seed-bearing plants the sporophyte generation is the only one seen by the nonbotanist. The gametophyte stage is of short duration and the parts are small; it is confined to the time of fertiliza. tion. 
The sporophyte of seed plants, or the "plant" as we know it, produces two kinds of spores - one kind becoming pollen-grains and the other kind embryo-sacs. The pollen-spores are borne in sporangia, which are united into what are called anthers. The embryo-sac, which contains the eser-cell, is borne in a sporangium known as an ovule. 1 samitophytic stage is presint in both pollcn and cmbryo sac: fertiliation talies place, and a sporophyte arises. Soon this sporophyte bicomes dormant, and is thin linown as an embryo. The embryo is packed away within tight-fitting coats, and the entire body is the seed. When the conditions are right the seed grows, and the sporophyte grows into herb, bush, or tree. The utility of the alternation of generations is not understood.

The spores of ferns are borne on leaves; the spores of seed-bearing plants are also borne amongst a mass of specially dereloped conspicuous leares known as flowers; therefore these plants have been known as the flowering plants. Some of the leaves are developed as envelopes (calyx, corolla), and others as spore-bearing parts, or sporophylls (stamens, pistils). But the spores of the lower plants, as of ferns and mosses, may also be borne in specially developed foliage, so that the line of demarcation between flowering plants and flowerless plants is not so definite as was once supposed. The one definite distinction between these two classes of plants is the fact that onc class froduces sects and the other docs not. The seed-plants are now often called spermaphytes, but there is no single coördinate term to set off those which do not bear seeds. It is quite as well, for popular purposes, to use the terms phenogams for the seed-bearing plants and cryptogams for the others. These terms have been objected to in recent years because their etymology does not express literal facts 
(phenogam signifying "showy flowers," and cryptogam "hidden flowers"), but the terms represent distinct ideas in classification. The cryptogams include three great series of plants - the Thallophytes or algx, lichens, and fungi ; the Bryophytes or mosslike plants; the Pteridophytes or fernlike plants.

Suggestions. - 186. The parts of a forn leaf. The primary complete divisions of a frond are called pinnæ, no matter whether the frond is pinnate or not. In ferns the word "pinna" is used in essentially the same way that leaflet is in the once-compound leaves of other plants. The secondary leaflets are called pinnules, and in thrice, or more, compound fronds, the last complete parts or leaflets are ultimate pinnules. The diagram (Fig. 263) will aid in making the subject clear. If the frond were not divided to the midrib, it would be simple, but this diagram represents a compound frond. The general outline of the frond, as bounded by the dotted line, is ovate. The stipe is very short. The midrib of a compound frond is known as the rachis. In a decompound frond, this main rachis is called the primary rachis. Segments (not divided to the rachis) are seen at the tip, and down to $h$ on one side and to $m$ on the

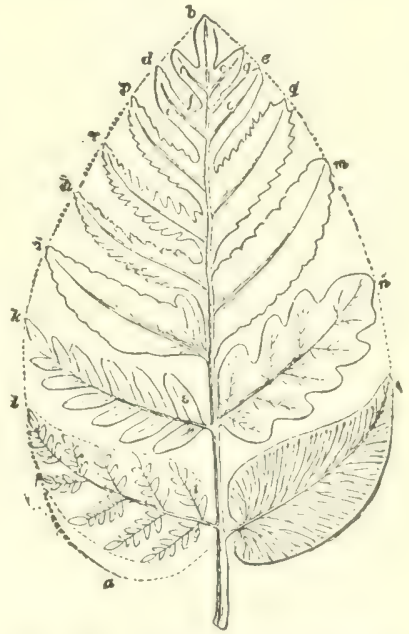

Fig. 263.-DIAGRAM TO EXPLAIN THE TERMINOLOGY OF THE FROND.

other. Pinnæe are shown at $i, k, l, o, n$. The pinna $o$ is entire; $n$ is crenate-dentate; $i$ is sinuate or wavy, with an auricle at the base ; $k$ and $l$ are compound. The pinna $k$ has twelve entire pinnules. (Is there ever an even number of pinnules on any pinna?) Pinna $l$ has nine compound pinnules, each bearing several entire ultimate pinnules. The spores. - 187. Lay a mature fruiting frond of any fern on white paper, top side up, and allow it to remain in a dry, warm place. The spores will discharge on the paper. 188. Lay the full-grown (but not dry) cap of a mushroom or toadstool bottom down on a sheet of clean paper, under a ventilated box in a warm, dry place, A day later raise the cap. 


\section{CHAPTER XXIV}

\section{STUDIES IN CRYPTOGAMS}

THE pupil who has acquired skill in the use of the compound microscope may desire to make more extended excursions into the cryptogamous orders. The following plants have been chosen as examples in various groups. Ferns are sufficiently discussed in the preceding chapter.

\section{BACTERIA}

If an infusion of ordinary hay is marle in water and allowed to stand, it becomes turbid or cloully after a few days, and a drop under the microscope will show the presence of minute oblong cells swimming in the water. perhaps by means of numerous hairlike* appendages, that project through the cell wall from the protoplasm within. At the surface of the dish containing the infusion the cells are non-motile and are united in long chains. Each of these cells or organisms is a bacterium (plural, bacteria). (Fig. I35.)

Bacteria are very minute organisms, - the smallest knownconsisting either of separate oblong or spherical cells, or of chains, plates, or groups of such cells, depending on the kind. They possess a membrane-like wall which, unlike the cell walls of higher plants, contains nitrogen. The presence of a nucleus has not been definitely demonstrated. Multiplication is by the fission of the vegetative cells; but under certain conditions of drought, cold, or exhaustion of the nutrient medium, the protoplasm of the ordinary cells may become invested with a thick wall, thus forming an cndospore which is very resistant to extremes of environment. No sexual reproduction is known.

Bacteria are very widely distributed as parasites and saprophytes in almost all conceivable places. Decay is largely caused by bacteria, accompanied in animal tissue by the liberation of foul-smelling gases. Certain species grow in the reservoirs and pipes of water supplies, rendering the water brackish and often undrinkable. Some kinds of fermentation (the breaking down or decomposing of organic compounds, usually accompanied by the 
formation of gas) are due to these organisms. Other bacteria oxidize alcohol to acetic acid, and produre lartiv acid in milk and iutyric acid in butter. Bacteria live in the mouth, the stomach, the intestines, and on the surface of the skins of animals. Some secrete gelatinous sheaths around themselves; others seerete sulphur or iron, giving the substratum a vivid cclour.

Were it not for bacteria, man could not live on the earth, for not only are they agents in the process of decay, but they are concerned in certain healthful processes of plants and animals. We have learned in (hapter VII how bacteria are related to nitrogen-gathering.

Bacteria are of economic importance not alone because of their effect on materials used by man, but also because of the diseaseprotucing poacer of certain species. Pus is caused by a spherical form, titinus or lock-jaze by a rorl-shaped form, diphtheria by short oblong chains, tuberculosis or "consumption" by more slender oblong chains, and tiphoid fer'er, cholera, and other diseases by other forms. Many discases of animals and plants are caused by bacteria. Disease-producing bacteria are said to be pathogenic.

The alility to grow in other nutrient substances than the natural one has greatly facilitated the study of these minute forms of life. By the use of suitable culture media and proper precautions, pure cultures of a particular disease-producing bacterium may be obtained with which further experiments may be conducted.

Milk provides an excellent collecting place for bacteria coming from the air, from the coat of the cow and from the milker. Disease germs are sometimes carried in milk. If a drop of milk is spread on a culture medium (as agar), and provided with proper temperature, the bacteria will multiply, each one forming a colony visible to the naked eye. In this way, the number of bacteria originally contained in the milk may be counted.

Bacteria are disseminated in water, as the germ of typhoid fever and cholera; in milk and other fluids; in the air; and on the bodies of flies, feet of birds, and otherwise.

Bacteria are thought by many to have descended from algre by the loss of chlorophyll and decrease in size due to the more specialized acquired saprophytic and parasitic habit.

\section{Algia:}

The algæ comprise most of the green floating "scum" which covers the surfaces of ponds and other quiet waters. The masses of plants are often called "frog spittle." Others are attached to stones, pieces of wood, and other objects submerged in streams 
and lakes, and many are found on moist ground and on dripping rocks. Aside from these, all the plants commonly known as seaweeds belong to this category; these latter are inhabitants of salt water.

The simplest forms of alga consist of a single spherical cell, which multiplies by repreated division or fission. Ninny of the forms found in fresh water are filamentous, i.c. the plant body consists of long threarls, either simple or branched. Such a plant body is termed a thallus. This term applies to the vegetative body of all plants that are nut differentiated into stem and leares. Such plants are known as thallophytes (P. I $8 \mathrm{I}$ ). All alga contain chlorophyll, and are able to assimilate carbon dioxicle from the air. This distinguishes them from the fungi.

Nostoc. - On wet rocks and damp soil dark, semitransparent irregular or spherical gelatinous masses about the size of a pea are often found. These consist of a colony of contorted filamentous algre embeded in the jelly-like mass. The chain of cells in the filament is necklace-like. Each cell is homogeneous, without apparent nucleus, and blue-green in wolour, except one cell which is larger and clearer than the rest. 'The plant therefore belongs to the group of blue-grecu alige. The jelly probably serves to maintain a more even moisture and to provide mechanical protection. Multiplication is wholly by the breaking up of the threads. Occasionally certain cells of the filament thicken to become restingspores, but no other spore formation occurs.

Oscillatoria. - The blue-green coatings found on damp soil and in water frequently show under the microscope the presence of filamentous algæ composed of many short

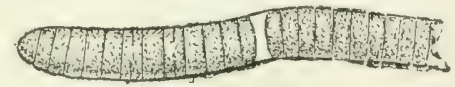

Fig, 264.-FILAMENT OF OScillatoria, showing one dead cell where the strand will break.

homogeneous cells (Fig. 264). If watched closely, some filaments will be seen to wave back and forth slowly, showing a peculiar power of movement characteristic of this plant. Multiplication is by the breaking up of the threads. There is no true spore formation.

Spirogyra. - One of the most common forms of the green algæ is spirogyra (Fig. 265). This

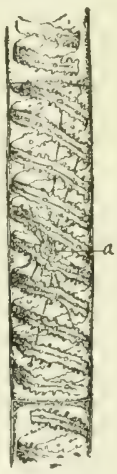

FIG. 265. - STRAND OF SPIKOGYRA, showing the chlorophyll bands. There is a nucleus at $a$. How many cells, or parts of cells, are shown in this figure ? 
plant often forms the greater part of the floating green mass (or "frog spittle") on ponds. The threadlike character of the thallus can be seen with the naked eye or with a hand lens, but to study it carefully a microscope magnifying two hundred diameters or more must be used. The thread is divided into long cells by cross walls which, according to the species, are either straight or curiously folded (Fig. 266). The chlorophyll is arranged in beautiful spiral bands near the wall of each cell. From the character of these bands the plant takes its name. Each cell is provided with a mucleus and other protoplasm. The nucleus is suspended near the centre of the cell ( $a$, Fig. 265 ) by delicate strands of protoplasm radiating toward the wall and terminating at certain points in the chlorophyll band. The remainder of the protoplasm forms a thin layer lining the wall. The interior of the cell is filled with cell-sap. The protoplasm and nucleus cannot be easily seen, but if the plant is stained with a dilute alcoholic solution of cosine they become clear.

Spirogyra is propagated vegetatively by the breaking off of parts of the threads, which continue to grow as new plants. Resting-spores,

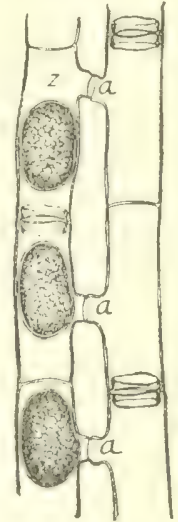

FIG. 266. - CONJUG.ITION OF SI'I ROGY RA. Ripe zygospores on the left; $a$, connecting tubes. which may remain dormant for a time, are formed by a process

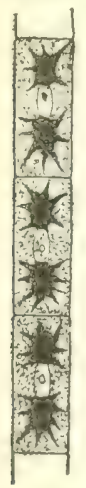

FIG. $267 .-$ STRAND, OR FILAMENT OF ZYGNEMA, freed from its gelatinous covering. known as conjugation. Two threads lying side by side send out short projections, usually from all the cells of a long series (Fig. 266). The projections or processes from opposite cells grow toward each other, meet, and fuse, forming a connecting tube between the cells. The protoplasm, nucleus, and chlorophyll band of one cell now pass through this tube, and unite with the contents of the other cell. The entire mass then becomes surrounded by a thick cellulose wall, thus completing the restingspore, or zygospore (z, Fig. 266).

Zygnema is an alga closely related to spirogyra and found in similar places. Its life history is practically the same, but it differs from spirogyra in having two stur-shafed chlorophyll liodit's (Fig. 267) in each cell, instead of a chlorophyll-bearing spiral band. 
Taucheriz is another alga common in shallow water and on damp soil. The thallus is much branched, but the threads are not divided by cross walls as in spirogyra. 'The plants are attached by me:ms. of colwuless rout-like organs which are much like the root hairs of the higher plants: these are rhisorids. The chlorophyll is in the form of grains scattered thromsth the thread.

Vaucheria has a special mode of asexual reproduction by means of swimming spores or saurm-spores. These are formed singly in a short enlarged lateral branch known as the sporangium. When the sporangium bursts, the entire contents escape, forming a single large swarm-spore, which swims about by means of numerous lashes or cilia on its surface. The swarm spores are so large that they can be seen with the naked eye. After swimming about for some time they come to rest and germinate, producing a new plant.

The formation of resting-spores of vaucheria is acomplished by means of special organs, ö̈gonia (o, Fig. 268) and antheridia

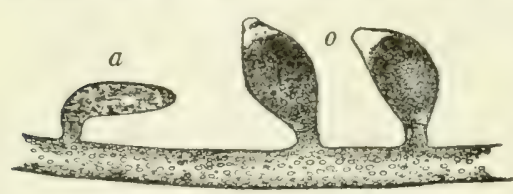

FIG, 268. - THREAD OF VAUCHERIA WITH OÖGONIA AND ANTHERIDIA.

(a, Fig. 268). These are both specially developed branches from the thallus. The antheridia are nearly cylindrical, and curved toward the oögonia. The upper part of an antheridium is cut off by a cross wall, and within it numerous ciliated sperm-cells are formed. These escape by the ruptured apex of the antheridium. The oögonia are more enlarged than the antheridia, and have a beak-like projection turned a little to one side of the apex. They are separated from the thallus thread by a cross wall, and contain a single large green cell, the egrr-cell. The apex of the oögonium is dissolved, and through the opening the sperm-cells enter. Fertilization is thus accomplished. After fertilization the egg-cell becomes invested with a thick wall and is thus converted into a resting-spore, the oüspore.

Fucus. - These are rather large specialized algæ belonging to the group known as brown seaweeds and found attached by a disk to the rocks of the seashore just below high tide (Fig. 269). They are firm and strong to resist wave action and are so attached as to aroid being washed ashore. They are very abundant algæ. In shape the plants are long, branched, and multicellular, with either flat or terete branches. They are olive-brown. Propagation is by the breaking off of the branches. No zoöspores are produced, as in many other seaweeds; and reproduction is wholly sexual. 
The antheridia, bearing sperm-cells, and the öggonia, each bearing eight egg-cells, are sunken in pits or conceptacles. 'These pits are aggregated in the swollen lighter coloureti tips of some of the branches (s, s, Fig. 269). The egg-celis and sperm-cells escape from the pits and fertilization takes place in the water. The matured eggs, or spores, reproduce the fucus plant directly.

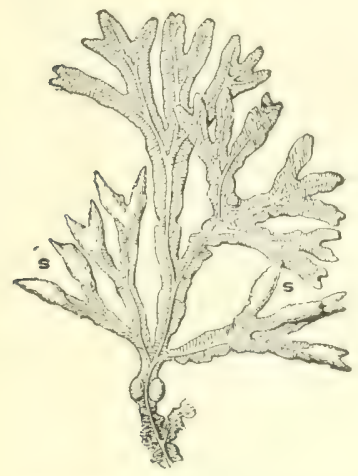

FIG. 269. - FUCUS, Fruiting branches at $s, s$. On the stem are two air-bladders.

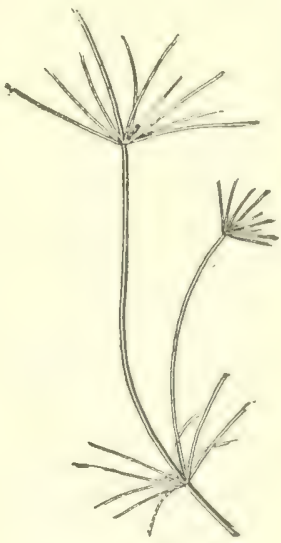

FIG. 270. - NITELLA.

Nitella. - This is a large branched and specialized fresh-water alga found in tufts attached to the bottom in shallow ponds (Fig. 270 ). Between the whorls of branches are long internodes consistiny of a single cylindrical cell, which is one of the largest cells known in vegetable tissue. Under the microscope the walls of this cell are found to be lined with a layer of small stationary chloroplastids, within which layer the protoplasm, in favourable eircumstances, will be found in motion, moving up one side and down the other (in rotation). Note the clear streak up the side of the cell and its relation to the moving current.

\section{FUNGI}

Some forms of fungi are familiar to every one. Mushrooms and toadstools, with their varied forms and coloursy are common in fields, woods, and pastures. In every household the common moulds are familiar intruders, appearing on old bread, vegetables, and even within tightly sealed fruit jars, where they form a feltlike layer dusted over with blue, yellow, or black powder. The strange occurrence of these plants long mystified people, who 
Wh they were productions of the dead matter upon which they werl, but now we know that a mould, as any other plant, eamot riginate spontaneously; it must start from something which is malogous to a seed. The "seed" is this case is a spore. A spore may be produced by a vegetative process (growing out from the ordinary plant tissues), or it may be the result of a fortilization process.

Fanurable conditions for the grouth of fungi.-Place a picee of bread under a moist bell jar anc. another in an uncovered place near by. Sow mould on each. Note the result from day to day. Joisten a third piece of lireat with weak copper suiphate

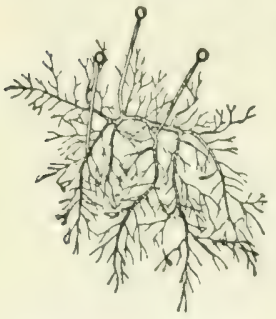

FIG. 27I. - MUCOR MUCEno, showing habit. (blue vitriol) or mereuric chloride solution, sow mould, cover with bell jar, note results, and explain. Expose piees of different kinds of food in a damp atmosphere and observe the variety of organisms appearing. Fungi are saprophytes or parasites, and must be provided with organic matter on which to grow. They are usually most abundant in moist places and wet seasons.

Mould.-One of these moulds (Mucor mucedo), which is very common on all vecaying fruits and vegetables, is shown in Fig. 271, somewhat magnifiel. When fruiting, this mould appears as a dense mass of long white hairs, often over an inch high, standing erect from the fruit or the vegetable on which it is growing.

The life of this mucor begins with a minute rounded spore (a, Fig. 272), which lodges on the deeaying material. When the spore germinates, it sends ont a delicate thread that grows rapisl? in length and forms very many branches that soon permeate every part of the substance on which the plant grows. (b, Fig. 272). One of these threads is termed a hypha. All the threads together form the mycclium of the fungus. The mycelium disorganizes the material in which it grows, and thus the mucor plant (Fig. 271) is nourished. It corresponds physiologically to the roots and the stems of other plants.

When the mycelium is about two days old, it begins to form the long fruiting stalks which we first noticed. To study them, use a compound microseope magnifying about two hudred diameters. One of the stalks, magnified, is shown in a, Fig. 274. It consists of a rounded head, the sporangium, sp, supported on a long, 
delicate stalk, the sforangiophore. The stalk is separated from the sporangium by a wall which is formed at the base of the sporangium. This wall, however, does not extend straight across the thread, but it arches up into the sporangium like an inverted pear. It is known as the columella, c. When the sporangium is placed in water, the wall immediately dissolves and allows hundreds of spores, which were formed in the cavity within the sporangium, to escape, $b$. All that is left of the fruit is the stalk, with the pear-shaped columella at its summit, $c$. The spores that have been set free by the breaking of the sporangium wall are now scattered by the wind and other agents. Those that lodge in favourable places begin to grow immediately and reproduce the fungus. 'The others soon perish.

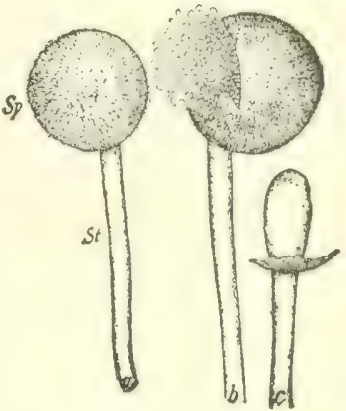

FIG. 274. - MUCOR.

$a$, sporangium; $b$, sporangium bursting; $c$, columella.

The mucor may continue to reproduce itself in this way indefi-

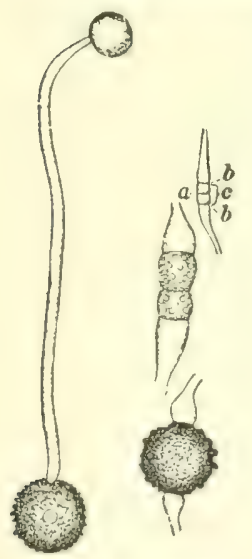

FIG. 273. - MICOR, showing formation of zygospore on the right; germinating zyguspore on the left. nitely, but these spores are very delicate and usually die if they do not fall on favourable ground, so that the fungus is provided with another means of carrying itself over unfavourable seasons, as winter. This is accomplished by means of curious thick-walled resting-spores or zygospores. The zygospores are formed on the mycelium buried within the substance on which the plant grows. They originate in the following way: Two threads that lie near together send out short branches, which grow toward each other and finally meet (Fig. 273). The walls at the ends, $a$, then disappear, allowing the contents to flow together. At the same time, however, two other walls are formed at points farther back, $b, b$, separating the short section, $c$, from the remainder of the thread. This section now increases in size and becomes covered with a thick, dark brown wall ornamented with thickened tubercles. The zygospore is now mature and, after a period of rest, it germinates, either producing a sporangium directly or growing out as mycelium.

The zygospores of the mucors form one of the most interesting and instructive objects among the lower plants. They are, however, very difficult to obtain. One of the mucors (Sporodinia 
srandis) may be frequently found in summer growing on toad. stmols. This plant usually produces zyospores that are formed on the aërial mycelium. The zygospores are large enough to be recognized with a hand lens. The material may be dried and kept for winter study, or the zygospores may be prepared for permanent microscopic mounts in the ordinary way.

Jiast. - This is a very much reduced and simple fungus, consisting normally of isolated spherical or elliptical cells (Fig. 275)

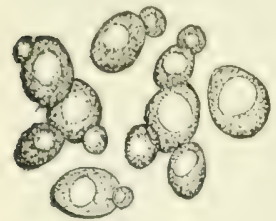

FIG, 275.-YEAST PI.AN'TS. containing abundant protoplasm and probably a nucleus, although the latter is not easily observed. It propagates rapidly by budding, which consists of the gradual extrusion of a wart-like swelling that is sooner or later cut off at the base by constriction, thus forming a separate organism. Although simple in structure, the yeast is found to be closely related to some of the higher groups of fungi as shown by the method of spore formation. When grown on special substances like potato or carrot, the contents of the cell may form spores inside of the sac-like mother cell, thus resembling the sac-fungi to which blue mould and mildews belong. The yeast plant is remarkable on account of its power to induce alcoholic fermentation in the media in which it grows.

There are many kinds of yeasts. One of them is found in the common veast cakes. In the process of manufacture of these cakes, the yeast cells grow to a certain stage, and the material is then dried and fashioned into small cakes, each cake containing great numbers of the yeast cells. When the yeast cake is added to dough, and proper conditions of warmth and moisture are provided, the yeast grows rapidly and breaks up the sugar of the dough into carbon dioxide and alcohol. This is fermentation. The gases escape and puff up the dough, causing the bread to rise. In this loosened condition the dough is baked; if it is not baked quickly enough, the bread "falls." Shake up a bit of yeast cake in slightly sweetened water: the water soon becomes cloudy from the growing yeasts.

Parasitic fungi--Most of the moulds are saprophytes. Many other fungi are parasitic on living plants and animals (Fig. 285). Some of them have complicated life histories, undergoing many changes before the original spore is again produced. 'The willow mililere and the common rust of reheat will serve to illustrate the habits of parasitic fungi.

The willow mildew (Uncinula salicis). - This is one of the sac fungi. It forms white downy patches on the leaves of willows 
(Fig. 276). These patches consist of numerous interwoven threads that may be recognized under the microscope as the mycelium of the fungus.

The mycelium in this case lives on the surface of the leaf and nourishes itself by sending short branches into the cells of the leaf to absorb food materials from

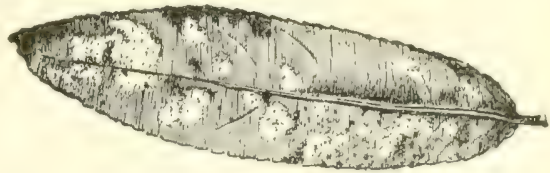

Fig. 276 - Colonies of Willow Milinew. them.

Numerous stmmer-spores are formed of short, erect branches all over the white surface. One of these branches is shown in Fig.

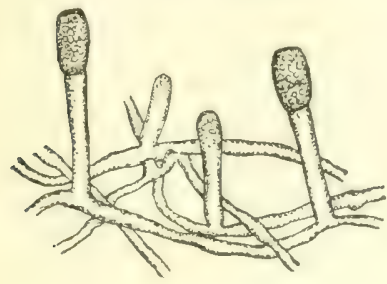

FIG. 277. - SUMMER-SPORES OF VILLOW MILDEW. 277. When it has grown to a certain length, the upper part begins to segment or divide into spores which fall and are scattered by the wind. Those falling on other willows reproduce the fungus there. This process continues all summer, but in the later part of the season provision is made to maintain the mildew through the winter. If some of the white patches are closely examined in July or August, a number of little black bodies will be seen among the threads. These little bodies are called perithecia, shown in Fig. 278 . To the naked eye

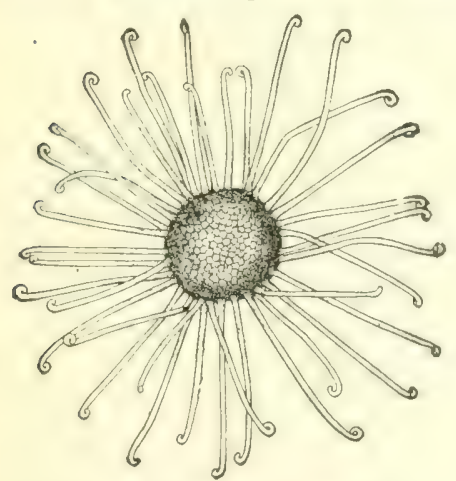

FIG. 278. - PERITHECIUII OF WIL LOW MILDEW. they appear as minute specks, but when seen under a magnification of 200 diameters they present a very interesting appearance. They are hollow spherical bodies decorated around the outside with a fringe of crook-like hairs. The resting-spores of the willow mildew are produced in sacs or asciinclosed within the leath-

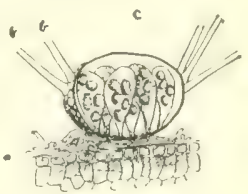

Fig. 279. - SEction THROUGH PERITHECIUM OF WILLOW MILDEW.

ery perithecia. Figure 279 shows a cross-section of a perithecium with the asci arising from the bottom. The spores remain securely 
packed in the perithecia. They do not ripen in the autumn, but fill to the ground with the leaf, and there aemain securely profected among the deat foliage. The following spring they mature and are liberated by the decay of the perithecia. They are then ready to attack the unfolding leaves of the willow and repeat the work of the summer before.

The a'licat mest. - The development of some of the rusts, as the common ahat rust (Puccinia graminis), is even more interesting

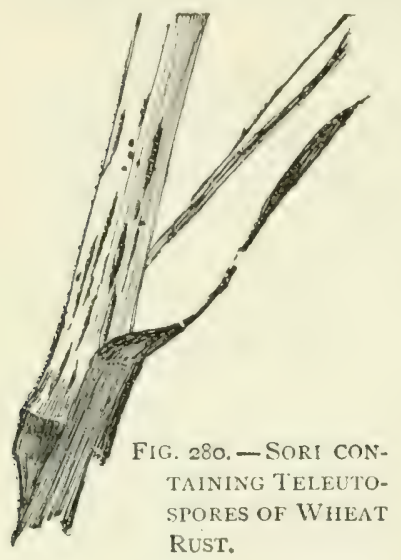
and complicated than that of the mildews. Wheat rust is also a true parasite, affecting wheat and a few other grasses. 'The mycelium here cannot be seen by the unaided eye, for it consists of threads which are present within the host plant, mostly in the intercellular spaces. These threads also send short branches, or haustoria (Fig. 132), into the neighbouring cells to absorb intriment.

The resting-spores of wheat rust are produced in late summer, when they may be found in black lines breaking through the epiclermis of the wheat stalk (black-rust stage). They are formed in masses, called sori (Fig. 280), from the ends of numerous crowded mycelial strands just beneath the epidermis of the host. The individual spores are very small and can be well studied only with a microscope of high power ( $X$ about 400). They are brown two-celled bodies with a thick wall (Fig. 28I). Since they are the resting or winter-spores, they are termed teleutospores ("completed spores"). Usually they do not fall, but remain in the șori during winter. The following spring each cell of the teleutospore puts forth a rather stout thread, which does not grow more than several times the length of the spore and terminates in a blunt extremity. This germ tube, promycelium, now becomes divided into four cells by cross walls, which are formed

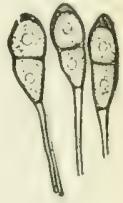

FIG: $28 \mathrm{I},-$ 'TE.

LEUTOSPORE OF IVHEAT RUST. from the top downwards. Each cell gives rise to a short, pointed branch which, in the course of a few hours, forms at its summit a single spore called a sporidium. This in turn germinates and produces a mycelium. In Fig. 282 a germinating teleutospore is drawn to show the promycelium, $p$, divided into four cells, 
each producing a short branch with a little sporiaizum, $s$.

A most remarkable circumstance in the life history of the wheat rust is the fact that the mycelium produced by the sporidium can live only in barberry leaves, and it follows that if no. barberry bushes are in the neighbourhoon the sporidia finally perish. Those which happen to lodge on a barberry bush germinate immediately, producing a mycelium that enters the barberry leaf and grows within its tissues. Very soon the fungus produces a new kind of spores on the barberry leaves. These are called acidiospores. They are formed in long chains in little fringed cups, or acidia, which appear in groups on the lower side of the leaf (Fig. $2 S_{3}$ ). These orange or yellow acilia are termed cluster-cups. In Fig. $2 S_{4}$ is shown a cross-section of one of the cups, outlin-

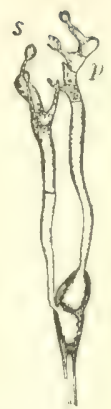

FIG. 282.- GFR. MINATING; TEI.EUTOSPURE OF WHFAT RUsT. ing the long chains of spores, and the mycelium in the tisstes.

The xcidiospores are formed in the spring, and after they have been set free, some of them lodge on wheat or other grasses, where they germinate inmediately. 'The germ-tube enters the

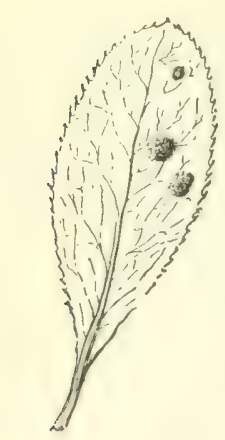

Fig. 283.-LEAF OF BARBERRY WITH CLUSTER-CUPS.

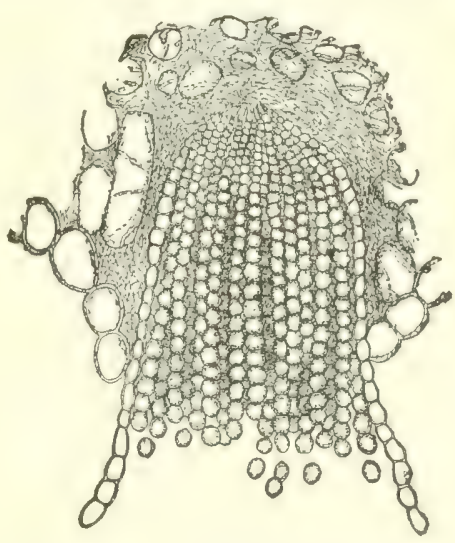

FIG. 28 . - SECTION THROUGH A Cluster-CUP ON BARBERrY LEAF.

leaf through a stomate, whence it sprearls among the cells of the wheat plant. In summer one-celled redrlish uredospores ("blight spores," red-rust stage) are produced in a manner similar to the teleutospores, These are capable of germinating immediately, 
and serve to disseminate the fungus ciuring the summer on other wheat plants or grasses. Latte in the scason, teleutospores are agrain produced, completing the life cycle of the plant.

Many rusts besides l'uciinia graminis produce different spore forms on different plants. 'The phenomenon is called hetercecism, and was first shown to exist in the wheat rust. Curiously enough, the peasants of Europe had observed and asserted that barberry bushes cause wheat to blight long before science explained the relation between the cluster-cups on barberry and the rust on wheat. The true relation was actually demonstrated, as has since been done for many other rusts on their respective hosts, by sowing the acidiospores on healthy wheat plants and thus producing

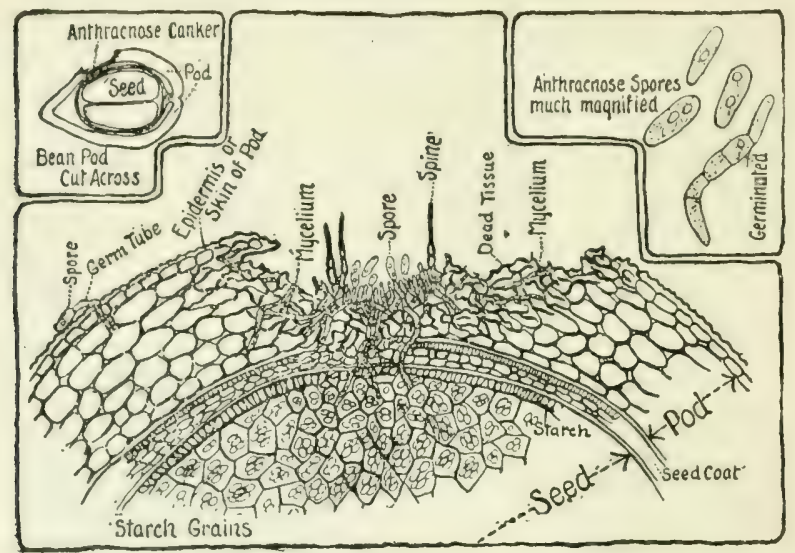

Fig. 285. - How a Parasitic Fungus works. Anthracnose on a bean pod entering the bean beneath. (Whetzel.)

the rust. The codar apple is another rust, producing the curious swellings often found on the branches of red cedar trees. In the spring the teleutospores ooze out from the "apple" in brownish yellow masses. It has been found that these attack various fruit trees, producing æcidia on their leaves. Fig. 285 explains how a parasitic fungus works.

Puffolls, mushrooms, toadstools, and shelf fungi. - These represent what are called the higher fungi, because of the size and the complexity of the plant body as weil as from the fact that they seem to stand at the end of one line of evolution. The mycelial threads grow together in extensive strands in rotten wood or in the soil, and send out large complex growths of mycelium in con- 
nection with which the spores are borne. These aerjal parts are the only ones which we ordinarily see, ant which constitute the "mushroom" part (Fig. I3I). Only asexual spores (basidiospores) are produced, and on short stalks (basidia) (Fig. 286). In the puffballs the spores are inclosed and constitute a large part of the "smoke." In the mushrooms and toadstools they are borne on gills, and in the shelf fungi (Fig. 134) on the walls of minute pores of the underside. The mycelium of these shelf fungi frequently lives and grows for a long time concealed in the substratum before the visible fruit bodies are sent out. Practically all timber decay is caused by such growth, and the damage is

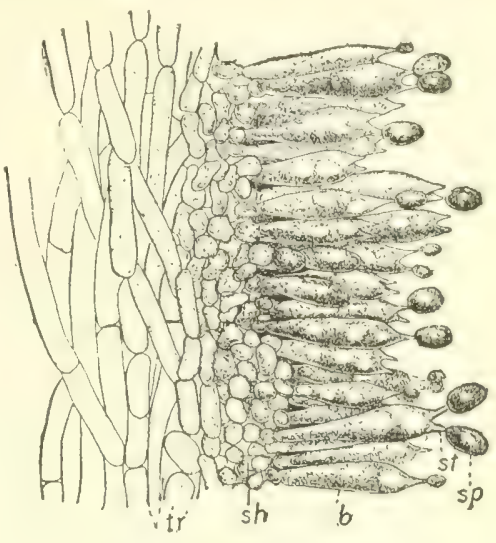

Fig. 286. - PART OF GILL OF THE CULTIVATED Mushroom.

tr, trama tissue; sh, hymenium; $b$, basidium; $s t$, sterigma; spp, spore. (Atkinson.)

largely done before the fruiting bodies appear. For other accounts of mushrooms, see Chapter XIV.

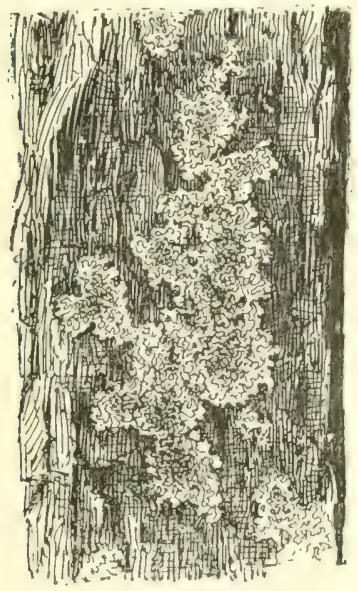

FIG. 237. - IICIIEN ON AN OAK TRLNK. (A species of Physcia.)

\section{LICHENS}

Lichens are so common everywhere that the attention of the student is sure to be drawn to them. "They grow on rocks, trunks of trees (Fig. 287 ), old fences, and on the earth. They are thin, usually gray ragged objects, apparently lifeless. Their study is too difficult for beginners, but a few words of explanation may be useful.

Lichens were formerly supposed to be a distinct or separate division of plants. 'They are now known to be organisms, each species of which is a constant association of a fungus and an alga. The thallus is ordinarily made up of fungous mycelium or tissue within which the imprisoned alga is definitely distributed. The result is a growth unlike either component, 'This association of 
alga and fungus is usually spoken of as stmbinsis, or mutually helpful growth, the alga furnishing some things, the fungus others, and both together being able to accomplish work that neither could do intependently. By others this union is considered to be a mild form of parasitism, in which the fungus profits at the expense of the alga. As farmuralile to this view, the ficts are cited that each component is able to grow independently, and that under such conditions the algal cells seem to thrive better than when imprisoned by the fungus.

Lichens propagate by means of seredia, which are tiny parts separated from the body of the thallus, and consisting of one or more algal cells overgrown with fungus threads. These are readily observed in many lichens. They also produce spores, usually ascospores, which are always the product of the fungus element, and which reproduce the lichen by germinating in the presence of algal cells, to which the hyphe immediately cling.

I.ichens are found in the most inhospitable places, and, by means of acids which they secrete, they attack and slowly disintegrate even the harlest rocks. By making thin sections of the thallus with a sharp razor and examining under the compound microscope, it is easy to distinguish the two components in many lichens.

\section{LIVERWORTS}

The liverworts are peculiar flat green plants usually found on wet cliffs and in other moist, shady places. They frequently occur in greenhouses where the soil is kept constantly wet.

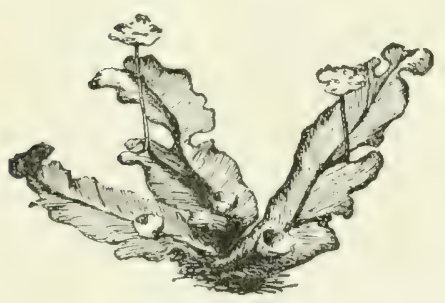

FIG. 288.

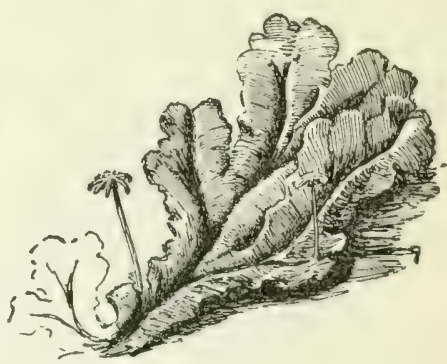

FIG. 289.

PLANTS OF MARCHANTIA.

One of the commonest liverworts is Marchantia polimorpha, two plants of which are shown in Figs. 288, 289. The plant consists of a ribbon-like thallus that creeps along the ground, becoming repeatedly forked as it grows. The end of each branch 
is always conspicuously notched. There is a prominent midrib extending along the centre of each branch of the thallus. On the under side of the thallus, especially along the midrib, there are numerous rhizoils which serve the purpose of roots, absorbing nourishment from the earth and holding the plant in its place. 'The upper surface of the thallus is divided into minute rhombic areas that can be seen with the naked eye. Each of these areas is perforated by a small breathing pore or stomate that leads into a cavity just beneath the epidermis. This space is surrounded by chlorophyllbearing cells, some of which stand in rows from the bottom of the cavity (Fig. 290). The delicate

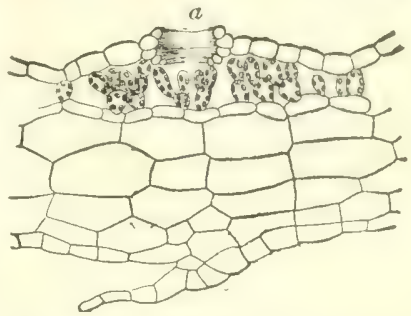

Fig. 290. - Section of Thallus of Marchantia. Stomate at $a$. assimilating tissue is thus brought in close communication with the outer air through the pore in the thick, protecting epidermis.

At various points on the midrib are little cups containing small green bodies. These bodies are buds or gemma which are outgrowths from the cells at the bottom of the cup. They become loosened and are then dispersed by the rain to other places, where they take root and grow into new plants.

The most striking organs on the thallus of marchantia are the peculiar stalked bollies shown in Figs. 288, 2S9. These are termed archegoniophores and antheridiophores or receptacles. Their structure and function are very interesting, but their parts are so minute that they can be stulied only with the aid of a microscope magnifying from 100 to 400 times. Enlarged drawings will guide the pupil.

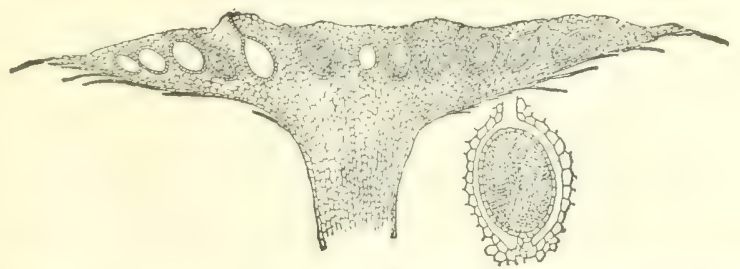

Fig. 29r. - Section 'mirnegh Axtieridiophore of Marchantia, showing antheridia. One antheridium more magnified.

The antheriliofhores are feshy, lobed disks borne on short stalks (Fig. 29I ). The upper surface of the disk shows openings scarrely visible to the nakerl eye. However, a section of the dirk, such as is drawn in Fig. 29I, shows that the pores lead into oblong cavi- 
ties in the receptacle. From the base of each cavity there arises a thick, club-shaped body, the antheridium. Within the anther-

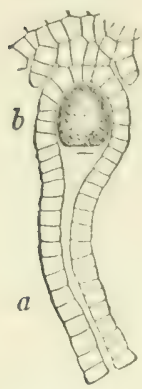

FIG. 292. -

Arcilegio-

NIUM UF

MARCHANTIA idium are formed many sperm -cells which are capable of swimming about in water by means of long lashes or cilia attached to them. When the antheridium is mature, it bursts and allows the ciliated sperm cells to escape.

The archegroniofinnes are also elevated on stalks (Fig. 2S9). Instead of a simple disk, the receptacle consists of nine or more finger-like rays. Along the under side of the rays, between delicately fringed curtains, peculiar flask-like borlies, or archegonia, are situated. The archegonia are not visible to the naked eye. They can be studied only with the microscope ( $X$ about 400). One of them much magnified is represented in Fig. 292. Its principal parts are the long neck, $a$, and the rounded i'enter, $b$, inclosing a large free cell - the egg-cell.

We have seen that the antheridium at maturity discharges its sperm-cells. These swim about in the water provided by the dew and rain. Some of them finally find their way to the archegonia and egg-cells, the latter being fertilized, as pollen fertilizes the ovules of higher plants.

After fertilization the egg-cell develops into the spore capsule or sporogonium. The mature spore capsules may be seen in Fig. 293. They consist of an oval spore-case on a short stalk, the base of which is imbedded in the tissue of the receptacle, from which it derives the necessary nourishment for the development of the sporogonium. At maturity the sporogonium is ruptured at the apex, setting free the spherical spores together with numerous filaments

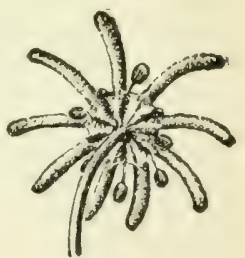

FIG, 293. -- ARCHEGONIOIHORE, WITH SPOROGONIA, OF MARCHANTIA. having spirally thickened walls (Fig. 294). 'These filaments are called elatirs. When drying, they exhibit rapid movements by means of which the spores are scattered. The spores germinate and again produce the $11 . . .1$ us of 1 archantia.

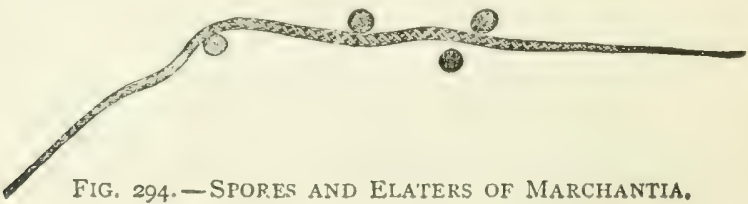




\section{Mosses (Bryophyta)}

If we have followed carefully the development of marchantia, the study of one of the mosses will be comparatively easy. 'The mosses are more faniliar plants than the liverworts. They grow on trees, stones, and on the soil in both wet and dry places. One of the common larger mosses, known as Polytrichum commune, may serve as an example, Fig. 295. This plant grows on rather dry knolls, mosily in the borders of open woods, where it forms large beds. In dry weather these beds have a reddish brown appearance, but when moist they form beautiful green eushions. This colour is due, in the first instance, to the colour of the old stems and leaves, and, in the second in: stance, to the peculiar action of the green living leaves under the influence of changing moisture-conditions. The inner or upper surface of the leaf is covered with thin, longitudinal ridges of delicate cells which contain chlorophyll. These cells are shown

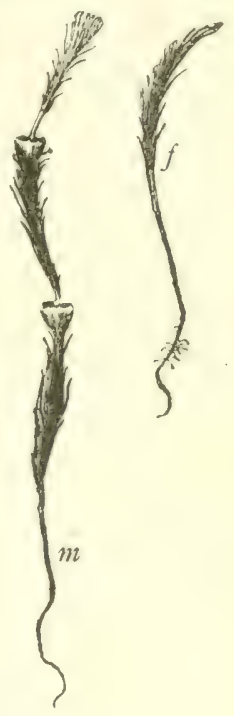

Fig. 295.- POLYTRICHUM COMMUNE.

$f, f$, fertile plants, one on the left in fruit; $m$, antheridial plant. in cross-section in Fig. 296 , as dots or granules. All the other tissue of the leaf consists of thick-walled, corky cells which do

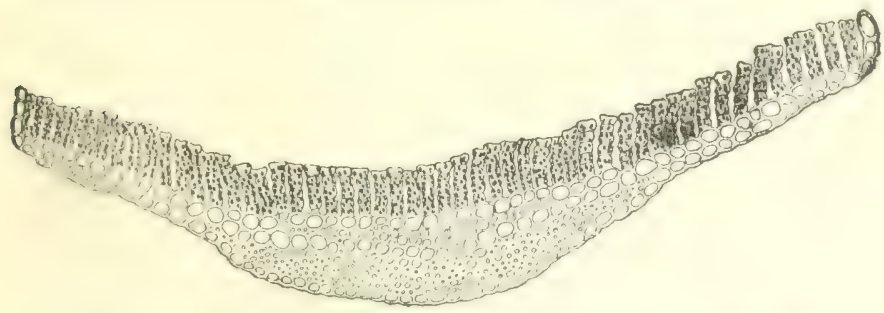

Fig. 296. - Section of Leaf CF POLytrichum COMMUNe.

not allow moisture to penetrate. When the air is moist the green leaves spread uut, exposing the chlorophyll cells to the air, but in 
dry weather the margins of the leaves roll inward, and the leaves folil closely against the stem, thus protecting the delicate assimilating tissue.

The antherific and archesonia of polytrichum are borne in groups at the ends of the branches on different plants (many mosies bear both organs on the same branch). 'They are surrounded by involucres of chanacteristic leaves termed perichetia or ferithital licte's. Multicellular hairs known as paraphlyses are scattered among the archegonia and antheridia. 'The involucres with the organs borne within them are calleal recentacles, or, less appropriately, "moss flowers." As in marchantia, the organs are very minute and must be highly magnified to be studied.

The antheridia are borne in broad cup-like receptacles on the antheridial plants (Fig. 297). They are much like the antheridia

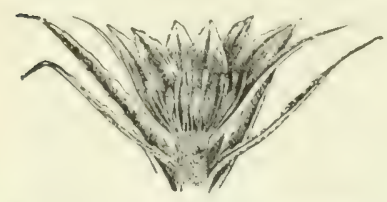

FIG. 297. - SH"THON THROLGII $\Lambda$ RECEPTACLE, OF POITIRICHum commune, showing paraphyses and antheridia. of marchantia, but they stand free among the paraphyses and are not sunk in cavities. At maturity they burst and allow the sperm cells or spermatozoids to escape. In polytrichum, when the receptacles have fulfilled their function, the stem continues to grow from the eentre of the cup ( $m$, Fig. 295). The archegonia are borne in other receptacles on different plants. They are like the archegonia of marchantia except that they stand erect on the end of the branch.

The sporogonium which develops from the fertilized egg is shown in $a$, $b$, Fig. 295. It consists of a long, brown stalk bearing the spore case at its summit. The base of the stalk is imbedded in the end of the moss stem by which it is nourished. The capsule is entirely inclused by a hairy cap, the calptra, $b$. The calyptra is really the remmant of the arcliegonium, which, for a time, increases in size to accommorlate and protect the young growing capsule. It is finally torn loose and carried up on the spore-case. The mouth of the capsule is closed by a circular lid, the operculum, having a conical projection at the centre.

The operculum soon drops, or it may be removed, displaying a fringe of sixty-four teeth guarding the mouth of the capsule. This ring of teeth is known as the peristome. In most mosses the teeth exhibit peculiar hygroscopic movements; i.c. when moist they bend outwards, and upon drying curve in toward the mouth of the capsule. This motion, it will be seen, serves to disperse these spores gradually over a long period of time.

Not tha entire eapsule is filled with spores. There are no elaters, but the centre of the eapsule is oceupied by a columnar 
strand of tissue, the columellu, which expands at the month into a thin, membranous disk, closing the entire mouth of the calpsule except the narrow annular chink guarded by the teeth. In this moss the points of the teeth are attached to the margin of the membrane, allowing the spores to sift out through the spaces between them.

When the spores germinate they form a green, branched thread, the protonema. This gives rise directly to moss plants, which appear as little buds on the thread. When the moss plants have sent their little rhizoids into the earth, the protonema dies, for it is no longer necessary for the support of the little plants, and the moss plants grow independently.

Funaria is a moss very common on damp, open soil. It forms green patches of small fine leaves from which arise long brown stalks terminated by curved capsules (liig. 298 ). 'The structure is similar to that of polytrichum, except the absence of plates on the under side of the leaves, the continuous growth of the stem, the curved

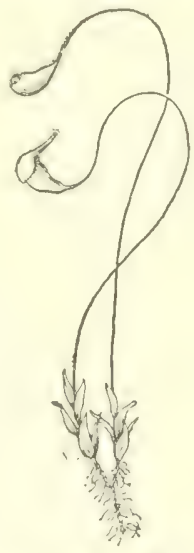

FIf. $2 g_{i}-\mathrm{Fu}-$ NARIA HYGRUSCUPICA. capsule, double peristome, moncecious rather than dicecious receptacles, and nearly glabrous unsymmetricai calyptra.

\section{Equisetuis, or Horsetails (Ptericlophyta)}

There are about twenty-five species of equisetum, constituting the only genus of the unique family Equisitucer. Among these E. arense (Fig. 299) is common on cliyey and sandy soils.

In this species the work of nutrition and that of spore production are performed by separate shoots from an underground rhizome. The fertile branches appear early in spring. The stem, which is 3 to 6 inches high, consists of a number of cylindrical, furrowed internodes, each sheathed at the base by a circle of scale leaves. The shoots are of a pale yellow rolour. They contain no chlorophyll, and are nourished by the food stored in the rhizome (Fig. 299).

The spores are formed on specially developed fertile leaves or sporophills which are collected into a spike or cone at the end of the stalk (a, Fig. 299). A single sporophyll is shown at $l$. It consists of a short stalk expaniled into a broad, mushroum-like head. Several large sporangic are borne on its under side. The spores formed in the sporangia are very interesting and beautiful 
objects when examined under the microscope ( $X$ about 200). The'y are spherical, green bodies, each surrounded by two spiral bands attached to the spore at their intersection, $s$. These bands exhilit hygroseopic movements by means of which the spores become entangled, and are held together. This is of advantage to the plant, as we shall see. All the spores are alike, lut some of the prothallia grow to a greater size than the others. The large prothallia produce only archegonia while the smaller ones produce antheridia. Both these ormans are mech like those of the ferns, and fertili-
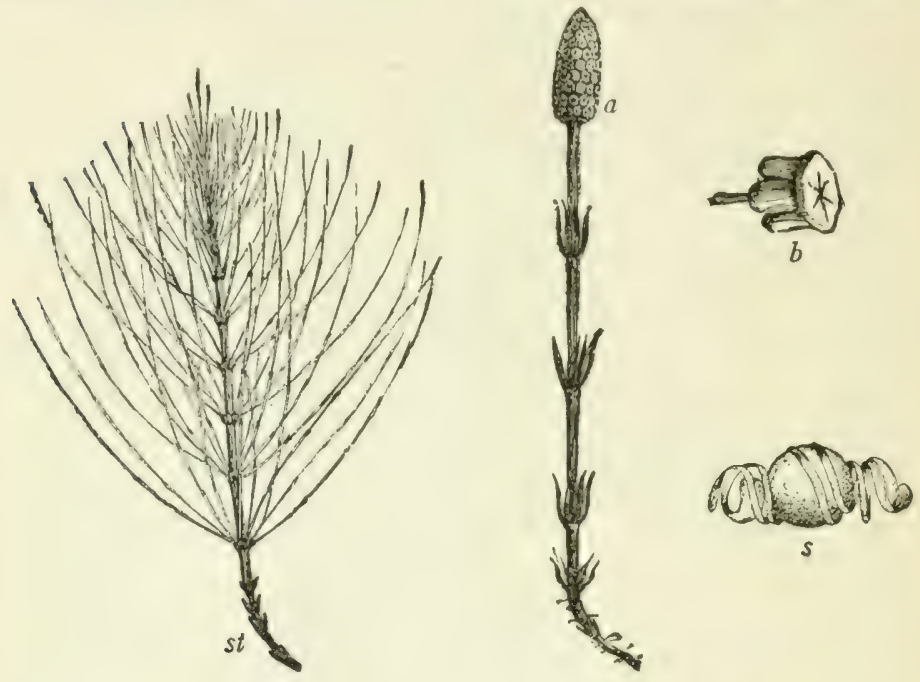

FIG. 299. - EQQUISETUM ARVENSE.

st, sterile shoot; $f$, fertile shoot showing the spike at $a ; b$, sporophyll, with sporangia; s, spore.

zation is accomplished in the same way. Since the prothallia are usually diøcious, the special advantage of the spiral bands, holding the spores together so that both kinds of prothallia may be in c lose proximity, will be easily understood. As in the fern, the fcrtilized egg-cell develops into an equisetum plant.

The sterile shoots (st, Fig. 299) appear much later in the season. They give rise to repeated whorls of angular or furrowed branches. The leaves are very much reduced scales, situated at the intersindes. The stems are provided with chlorophyll and act as nsimilating tissue, nourishing the rhizome and the fertile shoots. Nutriment is also stored in special tubers developed on the rhizome. 
Other species of equisetum have only one kind of shoot $-\mathrm{a}$ tall, hard, leafless, green shoot with the spike at its summit. Eyuisetum stems are full of silex, and they are sometimes used for scouring floors and utensils; hence the common name "scouring rush."

\section{IsoëTes (Pteridophyta)}

Isö̈tes or quillwort is usually found in water or damp soil on the edges of ponds and lakes. The general habit of the plant is seen in Fig. 300, $a$. It consists of a short, perennial stem bearing numerous erect, quill-like leaves with broad sheathing bases. The plants are commonly mistaken for young grasses.

Isoëtes bears two kinds of spores, large roughened ones, the macrospores, and small ones or microspores. Both kinds are formed in sporangia borne in an excavation in the expanded base of the leaf. The macrospores are formed on the outer and the microspores on the inner leaves. A sporangium in the base of a leaf is shown at $b$. It is partially covered by a thin membrane, the velum. The minute triangular appendage at the upper end of the sporangium is called the ligule.

The spores are liberated by the decay of the sporangia. They form rudimentary prothallia of two kinds. The microspores produce prothallia with antheridia, while the macrospores produce prothallia with archegonia. Ferti-

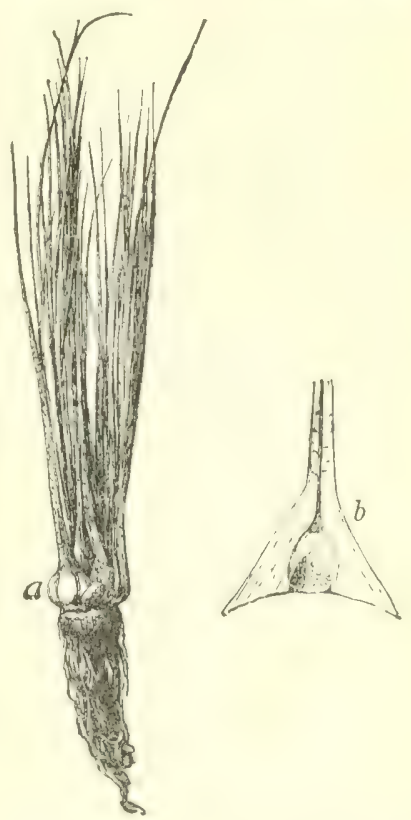

FIG. 300. - ISOËTES, showing habis of plant at $a ; b$, base of leaf, showing sporangium, velum, and ligule. lization takes place as in the mosses or liverworts, and the fertilized egg-cell, by continued growth, grives rise again to the isoëtes plant.

\section{Club-Mosses (Pteridophyta)}

The club-mosses are low trailing plants of moss-like looks and ?.uit, although more closely allied to ferns than to true mosses. Except one genus in Florida, all the club mosses belong to the 
genus Lucopolium. They grow mostly in woods, having $\mathbf{I}$-nerved evergreen leaves arranged in four or more ranks. Some of them make long strands, as the ground pine, and are much used for Christmas decorations. The spores are all of ane kind or form, borne in $I$-celled speramsig that open on the margin into treo valies. The sporangia are borne in some species (Fig. 301)

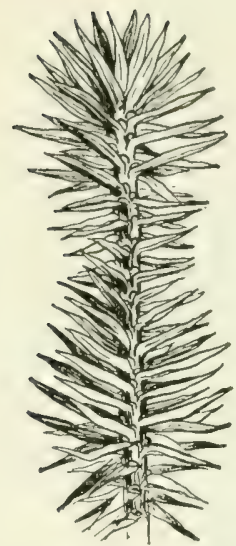

Fig. 30T. - A LYCOPODIUM WITH SPORANGIA IN THE AXIIS OF THE FOLIAGE LEAVES. (Lycopodium lucidulum.)

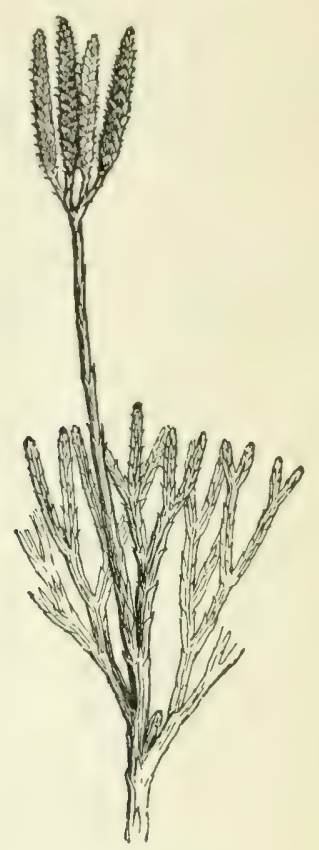

Fig. 302.-A Club-Moss (Lycopodium complanatum).

as small yellow bodies in the axils of the ordinary leaves near the tip of the shoot; in other species (Fig. 302) they are borne in the axils of small scales that form a catkin-like spike. The spores are very numerous, and they contain an oil that makes them inflammable. About roo species of lycopodium are known. The plants grown by florists under the name of lycopodium are of the genus Selaginella, more closely allied to isoëtes, bearing two kinds of spores (microspores and macrospores). 


\section{INDEX}

Aborted seeds, $₫ 66$.

Abutilon, $15^{5}$.

Accessory fruit, r64, I69.

Adaptation to environment, 6 .

Adventitious roots, 36 ; buds, I I 4 .

Aerial roots, 34 .

Aggregate fruit, I 68.

Air plants, 35.

Akenes, 165.

Algx, I 79, I83, 195.

Alternation of generation, I79.

Anemophilous, I49.

finnual plant, 17 .

Anther, I35, I 44, I80.

Antheridium, I78, I $86,198,200,202$, 203.

Apical dehiscence, I 66.

Archegonium, I 78, I9S, 200, 202, 203.

Arum family, 140 .

Ash, 92.

Assimilation, 97 .

Axil, I 12.

Axis, plant, I5.

Bacteria, 39, ro9, 182.

Barberry, $157,193$.

Bark, 54, 56, 67 .

Bark-bound trees, 54 .

Bast, 6I, 66.

Bean, 20, 28, 39, 194 .

Berry, 167.

Biennial plant, I 7 .

Brace cells, 67 .

Bracts, I 34.

Branch, II I.

Breeding, plant, 7, 8.

Bryophytes, $18 \mathrm{I}$.

Budding, I27, I 28.

Bud propagation, 181 .

Buds, $7^{2}, 82,87$, III; flower, II5; fruit, II 5 .

Burs, I 72, I 74 .

Bushes, I9I.

Cabbage, I I 3 .

Callus, 56.

Calyx, I 33 .
Cambium, 63, 65.

Capsule, 165.

Carbohydrate, 95.

Carbon, 92.

Carbon dioxide, 2:2, 9.3, 106.

Carnivorous, 99.

Carpel, I36.

Castor bean, 24 .

Catkin, ${ }_{58} 8$.

Caulicle, 20, 22, 25 .

Cedar apple, I94.

Cell, 42, 63, I 45, I 76 .

Chlorophyll, 86, 94, 10 r, I 83 , I 86 .

Scion, 1:25.

Cladophylla, ıоo.

Cleft graft, 126 .

Cleft leaf, 75 .

Cleistogamous, I 5 I.

Climbing plants, 129.

Clover, 39.

Club mosses, 203.

Cluster, Hlower, I55, I59; centrifugal, I56, I59; centripetal, I56; inde. terminate, 156 .

Colonies, plant, I I.

Composite flowers, I 40.

Conjugation, $\mathbf{1} 85$.

Cork, 66,67 .

Corn, 3, 25, 26.

Corolla, I33; funnel form, I38; labiate, I 38 ; personate, I 39; rotate, I 38 ; salver form, I 30 .

Cortex, 44.

Corymb, I 59.

Cotton plant, 7 .

Cotyledon, 20.

Cryptogam, I76, I80, I $83-204$.

Currant, 157 .

Cuttings, I 2 I, I23, I 24 .

Cyme, I 59, I60.

Deciduous, 82 .

Decumbent, 50.

Dehiscence, I44, $x 6_{4}$

Deliquescent, 5 I.

Dependent plants, Iо6.

Dichogamy, I44. 
Dicotyledon, 20.

Dicotyledonous stems, $6 \mathrm{r}$.

Digestion, 95.

Digitate, 74.

Dimorphous, I44.

Diocious, I 38 , I 70 .

Dispersal of seeds, 172.

Dissection, 30.

Dodder, 35, 106.

Drupe, 168.

Drupelet, 168.

Ecology, I4.

Elaters, 198.

Embryo, 26, 180.

Embryo sac, i 80.

Endodermis, 44.

Endosperm, 21, 24.

Entomophilous, 148 .

Environment, 6.

Epicotyl, 23, 25.

Epidermis, of leaf, 86,87.

Epigeal, 23.

Epiphyte, 35, I 10.

Equisetums, 20r.

Essential organs, 135 .

Excurrent, 5I.

Explosive seeds, $\mathbf{I} 72$.

Fermentation, I go.

Fern, I 76.

Fertilization, I44; cross, I44, I46; self, I 45, I 47, I 88 .

Fibro-vascular bundles, 61, 90.

Field study, 3, 6, 8, 14, 19, 27, 46, 57, $7 \mathrm{I}, 84,9 \mathrm{I}$, тоI, I1P, II $8,128,132$, I 43, I 52, I62, I 70, I74, I $8 \mathrm{I}$.

Filament, I 35 .

Floral envelopes, I 33 .

Florets, 140.

Flower, I33, I80; apetalous, I36; clusters, I55; complete, I36; diclinous, I37; double, I42; imperfect, 137; incomplete, I 36 ; lateral, I36; naked, I 36 ; perfect, I 37 ; pistillate,

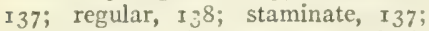
sterile, I37; solitary, I56; terminal, I 56.

Foliage, $x 6$.

Follicle, 165.

Forestry, 68 .

Framework of plant, I5.

Frond, 176, 178, 181 .

Fruit, 163 .

Fucus, 186.
Funaria, 20r.

Fungi, I 87 .

Fungus, 107, 108, 184, $877,195$.

Gametophyte, I 79.

Gamopetalous, I 34 .

Gamosepalous, I 34 .

Gencration of plants, $x 6$.

Gcotropism, 44, 47.

Germination, 22, 23, 2 ,.

Glomerule, I 60.

Grafting, I 25 .

Grit cells, 67 .

Guard cells, 88.

Gymnosperm, 26, x70.

Haits, 87 .

Herb, I7.

Hilum, 21, 26.

Hip, 168.

Hollyhock, 147.

Homologous, I 34, I 35 .

Host, 107.

Haustoria, 107.

Hyphæ, 10\%, 188.

Hypocotyl, 22.

Hypogeal, 23.

Indehiscent, I64.

Indusium, 177 .

Inflorescence, $155, \mathbf{1} 60$.

Internode, 52 .

Involucre, 34, I41, I63, I64.

Iron, 39 .

Isoëtes, 203.

Key fruit, 164.

Laboratory, 3 .

Landscape, I3.

Larkspur, 148, 149.

Latex tubes, 67 .

Leaf, apex of, 80 ; base of, 80 ; function of, 92 ; margin of, 80 ; structure, 86.

Leaf scar, 90.

Leaves, arrangement of, 82 ; shapes of, 78,85 .

Legume, 165.

Legume family, $35, x 69$.

Lenticel, 89.

Lichens, I95.

Ligneous, 17 .

Liverworts, I 96.

Lobes of leaf, 75 .

Locule, I 36, I $63,166$. 
Loculicidal dehiscence, I66.

Lumber, 68.

Lycopodium, 204.

Macrospore, 203, 204.

Marchantia, I96.

Medullary ray, 64.

Mesophyll, 86.

Micropyle, 2I, 26.

Microscope, 2I, 26.

Microspore, 203.

Midrib, 77 .

Mint family, 139.

Mistletoe, 109.

Mould, 188.

Monocotyledons, 20, 25, 63 .

Moncecious, 138 , 150 , 170 .

Mosses, I 99.

Moss, Spanish, I ro.

Mullein, 87 .

Muscadine, 36 .

Mushroom, 107, 194.

Mycelium, 107, 108, I88.

Mycorrhiza, 108.

Natural selection, 8.

Nectar, 148 .

Nitella, 187 .

Nitrogen, 39, 40.

Nodes, 20, 52 .

Nodules, 39, 40.

Nostoc, 184 .

Notebooks, 3 .

Nucleus, $x 44, x 85$.

Nuts, 164 .

Oleander, 86.

Ö̈gonia, r 86.

Orchid, 35, IIo.

Oscillatoria, 184.

Osmosis, 42, 48 .

Ovary, I $35,144,163,170$.

Overgrowth, I2.

Ovule, I 44, I86.

Palisade cells, 86.

Palmate, 74.

Panicle, 158.

Pappus, I4I.

Parasites, I07.

Parenchyma, 6o, 86.

Pedicel, I62.

Peduncle, 62.

Peltate, 77.

Perennial, 17 .
Pericarp, I64, I65, 169.

Petals, I 34 .

Petiole, 76.

Phenogam, I 77, I 80.

Photo-synthesis, 94, ror.

Phyllotaxy, 84 .

Pine cone, 27, 1 7o.

Pinna, r 8 r.

Pinnate, 74 .

Pinnatifid, 76 .

Pistil, I 35.

Plantain, 157.

Plant societies, 9.

Plants, unlikeness of, 9.

Plumule, 20, 23, 25.

Plur-annual, 18.

Pod, I64.

Pollen, $\mathrm{r} 35, \mathrm{r} 44, \mathrm{I} 80$.

Pollination, I44, I45; artificial. I 53.

Polypetalous, I 34 .

Polysepalous, 134 .

Polytrichum, I 99.

Pome, I 69.

Primrose, I 40.

Propagation by buds, I 2 I.

Prop-roots, 36 .

Proterandrous, I 46.

Proterogynous, 146 .

Prothallus, I 78, 202.

Protoplasm, 42, 94, 97, $x 85$.

Pruning, 105.

Pseud-annual, I7.

Pteridophytes, I8I, 201, 203.

Puffball, I 94.

Pyxis, I66.

Quarter-sawed, 7o.

Receptacle, I 34, I6 3.

Respiration, in plants, $97,103$.

Resting spore, I 84, I 85, I 89 , Iy $\mathrm{I}, .92$.

Rhizome, 52, 202.

Root cap, 44.

Root climber, I 29 .

Root hairs, 41, 42, 46.

Rootlet, 4I.

Root pressure, 99, ro4.

Roots, and air, 41; forms of, 32 ; func. tion, 38 ; structure, 38 , 43 ; systems, 32.

Rust, I 92.

Samara, I64.

Sap, 67 .

Saprophyte, 107, 108. 
Scape, $16 r$.

Scouring rush, 203.

Scramblers, 129.

Sced, 20, 163, 180; coat, 21.

Sclaginclla, 20.4.

Selection, natural, 8 ; artificial, 8.

Sepal, 133, 160.

Septicidal capsule, I 66.

Sessile, 77.

Shelf fungus, I94.

Shrub, I9.

Sieve tubes, 66.

Silicle, 167 .

Silique, 167 .

Societies, 9.

Soil, 40,47 .

Soredia, I96.

Sori, $177,192$.

Spadix, 140.

Spathe, $138,140$.

Spermatophytes, I So.

Spike, I 57 .

Spirogyra, I84.

Sporangium, I 77, I 86, I 88, 201, 203, 204.

Spore, I 76, I 78, I 81, I 84 .

Sporophyll, I 80,201 .

Sporophyte, I 77 .

Stamen, 135 .

Starch, 95, ror.

Stem, 49; endogenous, 59; exogenous, $6 \mathrm{I}$; kinds of, 49 .

Stigma, I 35, I 44, I45.

Stipule, 76, 84.

Stock, 125 .

Stomate, 87 .

Stone fruit, r 68 .

Storage of food, 99.

Struggle to live, 4,6 .

Style, I 35, I63.

Summer-spore, I 9 .

Sun energy: 05 .
Survival of fittest, 7 .

Sivarm-spores, 186.

Symbiosis, 196.

Syngenesious, I41.

T'cleutospores, 192.

'Tendril, Ior.

Thallophyte, $x 81,184$.

Thallus, I 84, 197 .

Thorns, rox.

Thyrse, 160.

Tillandsia, x 10.

Timber, decay of, 195 .

Tissue, 60, 62.

Toadstool, 194.

Torus, I 34, I69.

Tracheid, 65.

Transpiration, 98, Iс 3 .

Twiners, 129, I3I.

Umbel, I 59.

Undergrowth, I2.

Valve, I64.

Variation, 2.

Vaucheria, I86.

Verticellate, 84 .

Water-pore, 88.

Wheat rust, 102.

Whiteweed or ox-eye daisy, 155.

Whorled, 84.

Willow mildew, Igo.

Wind travelers, 17.3 .

Woody fibre, 17.

Wounds of plants, 56 .

Yeast plants, I 90.

Zygnema, 185 .

Zygospore, I 85, I8g. 


\section{GLOSSARY}

accessory or reinfurced fruts are those in which the ripened pericarp is combined with other parts, as with the torus or the calyx.

adte'entitious. Coming by chance or without order, as the sprouts that arise where a limb is cut off. argyregre fiuts are those in which several distinct pistils cohere to form one body, as in blackberry, raspberry, mulberry.

atiene or aihene. A one-seeded indehiscent fruit, usually small and seed-like.

analogons. Like to, in function or use. See homologous.

anemophilons. Said of flowers that are pollinated by the wincl.

anmual. A plant that naturally does not live more than one year, as garden bean, pea, Indian corn, buckwheat, cowpea.

anthir. The knob or enlargement of the stamen, bearing the pollen. antheridium. The male or sperm-cell organ. such as occurs on the prothallus of ferns and similar plants. See archegonium.

apetalous. Without petals.

apical. At the top.

archegromiunt. The female or egg-cell organ on the prothallus of ferns and related plants. See antheridium.

assimilatiun. The building up of protoplasm from the materials clabo. rated in the plant.

axil. The angle or place just above the petiole of a leaf (or pedicel of a flower) where it joins the twig.

bi\%. In botany, a fleshy pericarip containing a number of seeds, as current, orange, tomato, grape, cranberry, but not strawberry, blackberry, raspberry, or mulberry.

liennial. A plant that lives two years. It usually blooms the second year.

blade. The expanded part of a leaf.

bract. A small or much-reduced leaf, often a mere scale.

calyx. The outer row or series in the floral envelope. The outer "leaves" of the flower, usually green.

anntium. Growth tissue, lying between the lark-part and woud-part of the filro-vascular bundle and giving rise to the cells of both. 
cafsuli: A pod consisting of two or more carpels or parts, usually opening naturally.

carblindrate. The compounds of the starch and sugar class.

carpel. One part or member of a compound pistil, or a simple pistil itself.

catkun or ament. A raceme-like or spike-like flower-cluster that falls away after flowering or fruiting, as of willows and staminate flowerclusters of walruts and birches.

entrifuefol. From the insirle out; as a flower-eluster of which the inside, terminal, or uppermost flowers open first; a determinate cluster.

contripital. From the outside in; as a flower-cluster of which the outer flowers open first; an indeterminate cluster.

chlorophyll. Leaf green. Chlorophyll is the pigment that gives the characteristic colour to plants.

cladophylla. Stems that look like leaves, and function as leaves, as in asparagus and the florists' smilax.

cleistogamous. Applied to small flowers, usually hidden beneath the earth, that are little developed as to floral envelopes, and are selffertilized; also to self-fertilization in flowers that do not open. complete fowivers have all the parts, - calyx, corolla, stamens, pistil. corolla. The inner row or series of flower-leaves, usually coloured, and often of izycrular shape. It may be all one piece or of many pieces.

corymb. A flattish flower-cluster in which the outermost flowers open first.

cotylidon. A leaf of the embryo; seed-leaf. The embryo may have one cotyledon (monocotyledon), or two cotyledons (dicotyledon), or sometimes more than two.

cross-fertilization is fertilization by means of pollen produced in another flower.

cryptogam. One of the group of flowerless or non-seed-bearing plants, as a fern, fungus, moss, seaweed.

cutting. A shoot planted in soil or water for the purpose of making a new plant.

cymc. A flattish or broad flower-cluster in which the innermost or terminal flowers open first.

decumbent. Said of branches or stems that lop or lie over on the ground.

decurent. Said of a leaf that rins down on the stem, thereby not having a distinct petiole.

dehiscence. The mode of opening, as of a seed-pod or an anther. 
deliquescent. Said of trees in which the leader or main trunk disappears at the tree-top, forking into several or many main branches.

\section{determinate. See centrifugal.}

dichogrmy. The condition when stamens and pistils in the same flower mature at different times; this prevents or hinders selfpollination. See proterandrous and proterogynous.

diclinous. Said of flowers that are imperfect, - lacking cither stamens or pistils.

dicotyledon. Having two cotyledons or seed-leaves.

digestion. Change in the food materials whereby they my be trans-

ported, or used in assimilation. Starch is changed into sugar in the plant by a process of digestion.

dimerplous. Of two forms; as flowers that bear two kinds of stamens. diacintes. Said of plants that bear stamens and pistils in flowers on different plants.

drupi. A fleshy pericarp or fruit, containing a relatively large stone or pit, as peach, cherry, plum.

drupelet. A very small drupe, particularly one comprising part of an aggregate fruit, as a drupelet of raspberry.

embrye. The dormant plantlet comprising part of the seed. It is enclosed within the seed-coats. Its parts are the caulicle (or stemlet), cotyledons or seed-leaves, and plumule. The food may be stored in the embryo, or around the embryo (endosperm).

cudugren. A plant of the monocotyledon class, not enlarging in cliameter by means of outside rings; as palms. All grassses and lities and orchids and cereal grains are of this kind. Now usecl, if at all, to express a general mode of growth rather than a class of plants. See exogen.

cndisperm. The food material that is packed around the embryo (rather than inside it) in the seed.

cutomophiluns. Said of flowers that are pollinated by insects.

cnvironment. The surroundings; or the conditions in which a plant or animal lives. The environment comprises the soil, climate, and the influence of the other plants and animals with which or among which the plant or animal grows.

cpientyl. The internode or "joint "abuve the seed-leaves or cotyledons. cpidermis. The outermost layer or part of the cortex; the skin.

cpigeal. Said of seeds (as common xan) in which the cotyledons or seed-leaves rise above ground in germination. See hypescal.

cpiplyte. A plant that grows on another plant, or on uther olijects above ground, but which does not derive much or any of its nour. ishment from its host; an air-plant. 
camront. Said of trees (as firs and spruces) in which the main trunk or leader continues through the tree-top.

iaren (sec indegrn). Of the dicotyledon class, the stem enlarging by external layers or rings.

firtitization takes place in the flower when a pollen nucleus and an egg-cell nucleus unite in a forming ovule.

fibro-tiscular. I3undles or strands of tissue composed of sieve tubes, mechanical fibre and vessels or ducts.

filament. The stalk part of a stamen.

follicile: A single-cavity fruit or pod opening along its inner edge.

frond. A leaf of a fern and related plants.

fruit. In hotany, the ripened ovary with the attached parts. All

flowering plants, therefore, produce fruits. The term is also used

for the ripened reproductive bodies of flowerless plants.

finit-dut, somus. A collection or cluster of sporangia, as in ferns.

finction. What a plant or an organ does; how it works.

gamete. A cell or nucleus that takes part in fertilization.

simmethlyte. The stage of the plant (as the prothallus) that bears or

produces the sex organs; sexual stage of the plant.

gamopetalous. Said of a corolla with the petals united.

gamosepalous.. Said of a calyx with the sepals united.

generation. The entire life period of a plant.

geotropism. Turning toward the earth, as the action of the roots.

glomerule. A dense globular or oblong flower-cluster in which the upper or inner flowers open first.

graft. A cutting inserted in another plant for the purpose of having it grow there.

gymnosprim ("naked seed"). A name applied to a group of plants (pines, spruces, cedars, and the like) in which the seeds are not contained in an ovary.

head. A very dense globular or oblong flower-cluster in which the outer flowers open first; often applied to any dense flower-cluster. herb. A plant that never becomes woody and that dies to the ground, or dies entirely, in winter.

hitum. The scar or spot where the seed was attached to its stalk.

hip. The fruit of the rose, which is a hollowed torus containing the dry fruits or "seeds."

homolegous. Related to, or with, in origin or structure. Thus, a tendril of grape is homolngous with a branch; a tendril of grape is analogens to a tendril of pea (similar in function), but not homologous, for one represents a branch (or flower-cluster) and the other represents a leaf. 
host. A plant or animal on which another organism grows or fects. hypha (plural hypha). The threads of the mycelium of a fungus.

hypocoty?. The stem or internode below the seed-leaves.

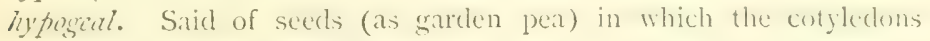
remain under ground in germination. Sec cpigeal.

imporfect flowers lack either stamens or pistils.

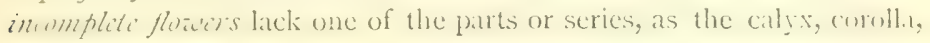
stamens, or pistil.

inditerminate. See centrifictal.

indusimn. The scale or lid covering a sorms, in forns and allied plunts. influses enie. Properly, the mode of flowering (page $1(60)$, hut some-

times used in the sense of a flower-cluster.

involucre. A set or whorl of leaves or bracts beneath a flower or a cluster of flowers; sometimes looks like an outer or extra calyx.

irentur flaters have some members of one or more of the series unlike their fellows.

kicy fruit. See samara.

labiatc. Lipped; that is, divided into parts, as the lips of a mouth. Said ustally of corollas that are lobed into two parts.

lifiral. On the side: as a flower or leaf borne on the side of a shoot rather than at its end. See terminal.

leaflet. One of the divisions or parts of a compound leaf.

legumi. Like a follicle, but opening along both edges. In some cases, as in peanut, the pod does not actually open.

leguninous plants are those that bear legumes or true pods, as peas, beans, clovers, alfalfa, vetch, sweet pea, peanut, locusts, red-bud.

lintid. lery smmll suts or corky clevations on young twigs marking the place of former twig stomates.

loculc. One cavity or "cell" in a pistil or anther.

lauliatir?. Said of capsules when the carpels or compartments open

between the partitions.

mescpizyll. The parenchyma in the leaf.

micropyle. The place on the seed at which the pollen-tube entered

when the seed was forming (when impregnation took place).

monocotylcdon. Having one cotyledon or seed-leaf.

mence imers. Said of plants that bear the stamens and pistils in different

flowers on the same plant.

suycelium. The regetative part of a fungus, composed of threarls in hyphx.

mycomhizit. A root corered with or bearing a fungus that aids the root in securing nourishment from the soil.

naked. Said of flowers that lack envelopes (calyx and corolla). 
ficher. I cup. sate, or place in the flumer in which nectar (ur "honey") is borne.

esmasis. The passing or dithusion of liguids or arases through nembranes.

saryy. The lower enlarged pillt of the pistil, containing the ovules or forming secds.

vonle. The young or forming seed.

fulmate. Palm-like; said of venation that arises from the base of the leaf (top) of petiole), or of leaflets similarly arranesed.

fancili. A branching raceme. The lower or outer flowers open first;

but the word is often used loosely.

fuppus. The harr, plumes, bristles, or scales on the top of a diry fruit.

particularly of a fruit (or "seed") of the Compositie or sunflowe

fanily.

parasite. i plant or animal that lives on a living host (as on a plant

or an animal), taking its food from the host. See suprophytc.

farenchima. The general underlying tissue, from which other tissue

arises.

paticl. Stem of a single flower in a cluster.

fichuile. A flower stem, supperting a solitary flower or a cluster of flowers.

frymial. A plant that lives more than two years, as most grasses,

docks, alfalfa, asparagus, and all trees and shrubs.

forfect flowers bear both stamens and pistils.

soriarp. A ripered ovary, without counting attached parts.

fersonatc. Masked; that is, so formed as to suggest a masked face;

in labiate corollas with a large lower lip.

pctal. One of the parts or leaves of the corolla.

pctiole. Stem or stalk of a leaf.

petiolule. Stem of a leaflet.

phinogam (phanegam, phaneregam). A seed-bearing plant; that is, one of the seed-bearing or flowering group of plants.

phlocm. Bark or soft bast tissue.

photosynthesis. The process whereby the earbon dioxicle of the air

is appropriated in the formation of material for plant growth.

phyllotaxy. Mode of arrangement of leaves or flowers on the plant or stem.

pimnate. Feather-like; said of leaves in which the veins strike off

from a continuing midrib, or in which the leaflets are arranged in a similar order.

pistil. The innermost member in the flower, bearing the forming seeds. pistillate. Of pistils only; a flower that contains pistils and no stamens, or a plant that bears only pistils. 
plur-etmmut. A plant of a tropical or semi-tropical climate that is annual in a colder country only because it is killed by frost; as tomato, castor-bean.

pollen. The dust or grains contained in the anther, which, falling on the stigma, grows and fertilizes the forming ovules.

polimation. The transfer of pollen from the anther to the stigma. The täansfer may be accomplished by wind, insects, lirds, water (in the case of water plants), or ly the natual falling of the pollen. polypetaleres ("many-petaled"). Sirid of a corolla with the petals not united.

polysepalous ("many-sepaled"). Said of a calyx with sepals not united. pome. An apple-like or pear-like or quince-like fruit, with a five-carpeled or cen-carpeled "core."

proterandrous. Said of a flower when the anthers mature in advance of the pistils in the same flower.

proterengneus. Said of a flower when its pistils mature before its anthers.

protiullus ("first thallus"). The minute leaf-like body or oran produced by the germination of a spore, in ferns and allied plants. It bears the sex organs.

frotopiasm. The living matter in plants. It is the living part of the ceils, usually in a semi-fluid, translucent state.

pisut-anmul. A plant that is apparently anrul. but which is carried over winter by a bulb, tuber, or similar body; as potato, onion.

pyris. A dry fruit or capsule in which the top comes off, like a cover to a jar.

raceme. A simple (unbranched) cluster in which the flowers are on short pedicels and open from the base upwwards.

raple. A riclge or elevation on some seeds caused ly the seed-stalli and seed-coats growing together.

ray. The elongated corolla-limb of some members of the Compositie family.

receptive. Said of a stigma when it is "ripe" or ready to receive the pollen.

regular fluwers are those in which all the members of each series (as all the sepals, or all the petals, or all the stamens) are like each other in shape, size, and colour.

reinforced. See accessory fruits.

respiratim. Breathing; manifest by oxygen taken in and carbon dioxidle given off.

rhizome. A rootstock; an underground root-like stem. It has joints, usually scales representing leaves, and is often thick and fleshy. 
samary. A key frut, heing an inclehiscent (not opening) fruit previded with a wing or wings.

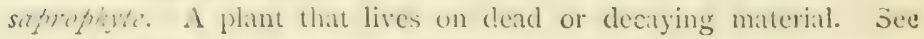
parasite.

siafi. A thower-stem rising directly from the crown of the plant at the surface of the ground or near it. A scape may have bracts.

silf-jertilization or close-firtiliation is furtilization by means of pollen produced in the same flower.

sepal. One of the parts or leaves of the calyx.

sifflitilat. A form of dehiscence or opering along the natural partitions of the capsule.

sissile. Sitting; without a stem, as a leaf without petiole, or a flower without pedicel or peduncle.

shimb. A low woody plant that does not have a distinct trunk. When a plant normally has a trunk, it is a tree.

silicle. A short, more or less circular, capsule of the mustard family. silique. A long capsule of the mustard family.

seciety. An aggregation or comprany of plants, comprising a more or less distinct group.

sorus (plural sori). See fruit-dot.

sparlix: A spike of flowers (each flower usually minute), with a more or less fleshy axis, and usually accompanied by a spathe.

spathe. A corolla-like or involucre-like leaf o: bract (or a pair of them) surrounding or accompanying a spadix. In the calla, the spathe is the large white flower-like part.

spermaphyte ("seed plant"). A seed-bearing plant; one of the flowering-plant class.

spizic. A dense and slender flower-cluster in which the flowers open from below upwards.

sporangium (plural sporangia; spore-case). A body or receptacle holding spores.

spore. A reproductive or generative cell; in flowerless plants answering the purpose of a seed, but containing no embryo. It may not

be the direct product of fertilization. sporophyll ("spore leaf"). A member or part that bears spores. sporophyte. The stage of the plant arising directly from the fertilized egg, and which ordinarily produces asexual spores (as the "plant" or conspicuous part of the fern or of a seed-plant).

stamen. The pollen-bearing organ of the flower, of which the essential part is the anther (usually borne on a stem or filament). stuminate. Said of a flower that has stamens and no pistils. stigma. The part of the pistil (usually on a stalk or style) on 
which the pollen germinates; it is sticky, rough, or hairy at maturity.

stipel. A stipule of a leaflet.

stipule. A leafy or scale-like appendage at the base of a petiole.

Stipules are usually two in each case.

stomatc, stoma (plural stomates or stomata). The openings on leaves and green parts through which gase's pass; diffusion-pores or "breathing-pores."

stone-finit. A drupe.

strit. Said of a stem that grows straight up, without breaking into branches.

style. The stalk between the orary and the stigma; sometimes not present.

syngenesious. Said of anthers when they cohere in a ring, as in the Composite, the style usually being inelosert.

tap-root. A single or leadling strong root that runs straight down into the earth.

temdril. A slender coiling member of a plant that enables it to climb.

A tenhil may represent a branch, a petiole, a leaflet, a stipule, an entire leaf.

terminal. At the end; as a flower borne on the end of a shoot. See lateral.

ilyyse. A compound, usually elongated or pyrmichal flower-cluster in which the mode of inflorescence is mixed.

torus. The end of the flower-stalk (usually somewhat enlarged) to which the flower-parts are attached; receptacle.

transpiration. Evaporation or loss of water from plants.

ambel. A flower-cluster opening from the outside, in which the branches or stems arise from one place, as the rays of an opened umbrella. unbellet. A small umbel, comprising part of a larger or compund umbel.

anter. One of the integral parts into which a fruit or an anther naturally splits, or into which it is divided.

sematim. The mode or fashion of veining, as in a leat or petal. xylem. Wood tissue. 





581

This card is to be kept in this pocket and returned with the book.

No book will be loaned without presentation of the borrower's card.

This book must be returned on or before the last date stamped on the card.

If not requested by another borrower the loan may, on application, be renewed.

This book must not be marked or mutilated in any way.

In case of loss its value must be paid to the Librarian.

Any violation of these rules may deprive the borrower of any further privileges of the Library.

Department of Education, Toronto. 
